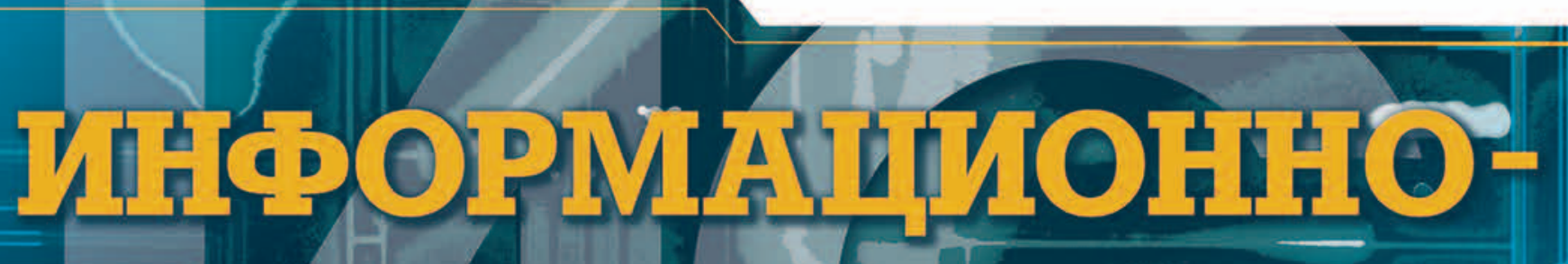

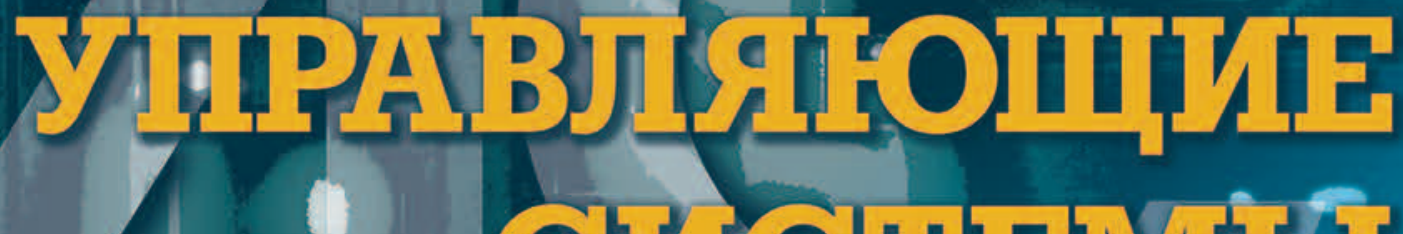 \\ CNGHENTा
}

\section{НАУЧНЫЙ ЖУРНАЛ}

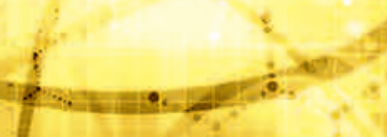




\section{$5(102) / 2019$}

\section{PEER REVIEWED JOURNAL}

\section{UPRAVLIAIUSHCHIE SISTEMY} (INFORMATION AND CONTROL SYSTEMS)

Founder

«Information and Control Systems», Ltd.

Publisher

Saint-Petersburg State University

of Aerospace Instrumentation

Editor-in-Chief

M. Sergeev
Dr. Sc., Professor, Saint-Petersburg, Russia

Deputy Editor-in-Chief

E. Krouk
Dr. Sc., Professor, Moscow, Russia

Executive secretary

O. Muravtsova

Editorial Board

$\mathrm{S}$. Andreev

Dr. Sc., Tampere, Finland

V. Anisimov

Dr. Sc., Professor, Saint-Petersburg, Russia

B. Bezruchko

Dr. Sc., Professor, Saratov, Russia

N. Blaunstein

Dr. Sc., Professor, Beer-Sheva, Israel

C. Christodoulou

PhD, Professor, Albuquerque, New Mexico, USA

A. Dudin

Dr. Sc., Professor, Minsk, Belarus

I. Dumer

PhD., Professor, Riverside, USA

M. Favorskaya

Dr. Sc., Professor, Krasnoyarsk, Russia

L. Fortuna

PhD, Professor, Catania, Italy

A. Fradkov

Dr. Sc., Professor, Saint-Petersburg, Russia

A. Hramov

Dr. Sc., Professor, Innopolis, Russia

L. Jain

PhD, Professor, Canberra, Australia

V. Khimenko

Dr. Sc., Professor, Saint-Petersburg, Russia

G. Maltsev

Dr. Sc., Professor, Saint-Petersburg, Russia

G. Matvienko

Dr. Sc., Professor, Tomsk, Russia

A. Myllari

PhD, Professor, Grenada, West Indies

Y. Podoplyokin

Dr. Sc., Professor, Saint-Petersburg, Russia

K. Samouylov

Dr. Sc., Professor, Moscow, Russia

J. Seberry

PhD, Professor, Wollongong, Australia

A. Shalyto

Dr. Sc., Professor, Saint-Petersburg, Russia

A. Shepeta

Dr. Sc., Professor, Saint-Petersburg, Russia

Yu. Shokin

RAS Academician, Dr. Sc., Novosibirsk, Russia

A. Smirnov

Dr. Sc., Professor, Saint-Petersburg, Russia

T. Sutikno

PhD, Associate Professor, Yogyakarta, Indonesia

Z. Yuldashev

Dr. Sc., Professor, Saint-Petersburg, Russia

R. Yusupov

RAS Corr. Member, Dr. Sc., Professor, Saint-Petersburg, Russia

A. Zeifman

Dr. Sc., Professor, Vologda, Russia

Editor: A. Larionova

Proofreader: T. Zvertanovskaia

Design: M. Chernenko, Y. Umnitsina

Layout and composition: Y. Umnitsina

Contact information
The Editorial and Publishing Center, SUAI

67, B. Morskaia, 190000, St. Petersburg, Russia

Website: http://i-us.ru/en, e-mail: ius.spb@gmail.com

Tel.: +7 - 8124947002

The Journal was registered in the Ministry of Press,

Broadcasting and Mass Media of the Russian Federation

Registration Certificate JD № 77-12412 from April, 19, 2002.

Re-registration in the Federal Service for Supervision in the Sphere of Telecom, Information Technologies and Mass Communications (ROSKOMNADZOR)

due to change of the founder: «Information

JD № FS77-49181 from March,
THEORETICAL AND APPLIED MATHEMATICS

Abuzin L. V., Balonin N. A., Đoković D. Ž., Kotsireas I. S. Hadamard

matrices from Goethals - Seidel difference families with a repeated block

\section{INFORMATION PROCESSING AND CONTROL}

Osipov V. Yu., Nikiforov V. V. Recurrent neural networks with controlled elements in restoring frame flows

SYSTEM AND PROCESS MODELING

Anisimov V. G., Anisimov E. G., Saurenko T. N., Zotova E. A. Models of

forecasting destructive influence risks for information processes

in management systems

HARDWARE AND SOFTWARE RESOURCES

Tatarnikova T. M. Restricting data leakage through non-obvious features of Android 5 smartphone

Kuleshov S. V., Zaytseva A. A., Shalnev I. O. Distributed system of virtual machines for self-organized networks

INFORMATION CHANNELS AND MEDIUM

Astakhova T. N., Verzun N. A., Kasatkin V. V., Kolbanev M. O., Shamin A. A. Sensor network connectivity models

SYSTEM ANALYSIS

Begishev V. O., Sopin E. S., Molchanov D. A., Samouylov A. K., Gaidamaka Yu. V., Samouylov K. E. Performance evaluation of bandwidth reservation for $\mathrm{mmW}$ Wave $5 \mathrm{G}$ NR systems

CONTROL IN MEDICAL AND BIOLOGICAL SYSTEMS

Aksenov I. V., Dobrenko N. V., Vatyan A. S., Kapustin R. O., Osipov S. V., Mavrin P. Y., Gusarova N. F., Shalyto A. A. Automata approach for personalized support of clinical processes in healthcare

Submitted for publication 03.09.19. Passed for printing 15.10.19. Format $60 \times 84_{1 / 8}$ Phototype SchoolBookC. Digital printing.

Layout original is made at the Editorial and Publishing Center, SUAI.
67 , B. Morskaia, 190000, St. Petersburg, Russia Printed from slides at the Editorial and Publishing Center, SUAI. 67, B. Morskaia, 190000, St. Petersburg, Russia 


\section{$5(102) / 2019$}

ИНФОРМАЦИОННОУПРАВЛЯЮЩИЕ

РЕЦЕНЗИРУЕМОЕ ИЗДАНИЕ СИСТЕМЫ

Учредитель

ООО «Информационно-управляющие системы»

Издатель

Санкт-Петербургский государственный университет

аэрокосмического приборостроения

Главный редактор

М. Б. Сергеев,

д-р техн. наук, проф., Санкт-Петербург, РФ

Зам. главного редактора

Е. А. Крук,

д-р техн. наук, проф., Москва, РФ

Ответственный секретарь

Ответственный
О. В. Муравцова

Редакционная коллегия:

С. Д. Андреев,

д-р техн. наук, Тампере, Финляндия

В. Г. Анисимов,

д-р техн. наук, проф., Санкт-Петербург, РФ

Б. П. Безручко,

д-р физ.-мат. наук, проф., Саратов, РФ

Н. Блаунштейн,

д-р физ.-мат. наук, проф., Беэр-Шева, Израиль

Л. С. Джайн,

д-р наук, проф., Канберра, Австралия

А. Н. Дудин,

Д-р физ.-мат. наук, проф., Минск, Беларусь

И. И. Думер,

д-р наук, проф., Риверсайд, США

А. И. Зейфман,

д-р физ.-мат. наук, проф., Вологда, РФ

К. Кристодолу,

д-р наук, проф., Альбукерке, Нью-Мексико, США

Г. Н. Мальцев,

д-р техн. наук, проф., Санкт-Петербург, РФ

Г. Г. Матвиенко,

д-р физ.-мат. наук, проф., Томск, РФ

А. А. Мюлляри,

Д-р наук, профессор, Гренада, Вест-Индия
Ю. Ф. Подоплёкин,

д-р техн. наук, проф., Санкт-Петербург, РФ

К. Е. Самуйлов,

д-р техн. наук, проф., Москва, РФ

Д. Себерри

д-р наук, проф., Волонгонг, Австралия

А. В. Смирнов,

д-р техн. наук, проф., Санкт-Петербург, РФ

Т. Сутикноу,

д-р наук, доцент, Джокьякарта, Индонезия

М. Н. Фаворская,

д-р техн. наук, проф., Красноярск, РФ

Л. Фортуна,

д-р наук, проф., Катания, Италия

А. Л. Фрадков

д-р техн. наук, проф., Санкт-Петербург, РФ

В.И. Хименко,

д-р техн. наук, проф., Санкт-Петербург, РФ

А. Е. Храмов,

д-р физ.-мат. наук, Иннополис, РФ

А. А. Шалыто,

д-р техн. наук, проф., Санкт-Петербург, РФ

А. П. Шепета,

д-р техн. наук, проф., Санкт-Петербург, РФ

акад. РАН, д-р ф

д-р техн. наук, про

Р. М. Юсупов,

чл.-корр. РАН, д-р техн. наук, проф., Санкт-Петербург, РФ

Редактор: А. Г. Ларионова

Корректор: Т. В. Звертановская

Дизайн: М. Л. Черненко, Ю. В. Умницына

Компьютерная верстка: Ю. В. Умницына

Адрес редакции: 190000 , Санкт-Петербург,

Б. Морская ул., д. 67, ГУАП, РИЦ

Тел.: (812) 494-70-02, эл. адрес: ius.spb@gmail.com,

сайт: http://i-us.ru

Журнал зарегистрирован в Министерстве РФ по делам печати, телерадиовещания и средств массовых коммуникаций. Свидетельство о регистрации ПИ № 77-12412 от 19 апреля 2002 г.

Пвидетельство о регистрации ПИ № ФС77-49181 от 30 марта 2012 г.

๑) Коллектив авторов, 2019
ТЕОРЕТИЧЕСКАЯ И ПРИКЛАДНАЯ МАТЕМАТИКА

Abuzin L. V., Balonin N. A., Đoković D. Ž., Kotsireas I. S. Hadamard matrices from Goethals - Seidel difference families with a repeated block

ОБРАБОТКА ИНФОРМАЦИИ И УПРАВЛЕНИЕ

Осипов В. Ю., Никифоров В. В. Возможности рекуррентных

нейронных сетей с управляемыми элементами по восстановлению потоков кадров

МОДЕЛИРОВАНИЕ СИСТЕМ И ПРОЦЕССОВ

Anisimov V. G., Anisimov E. G., Saurenko T. N., Zotova E. A. Models of forecasting destructive influence risks for information processes

in management systems

ПРОГРАММНЫЕ И АППАРАТНЫЕ СРЕДСТВА

Татарникова Т. М. Ограничения утечки информации посредством неочевидных функций смартфона Android 5

Кулешов С. В., Зайцева А. А., Шальнев И. О. Подход

к реализации распределенной системы виртуальных машин

для самоорганизующихся сетей

ИНФОРМАЦИОННЫЕ КАНАЛЫ И СРЕДЫ

Астахова Т. Н., Верзун Н. А., Касаткин В. В., Колбанев М. О.

Шамин А. А. Исследование моделей связности сенсорных сетей

СИСТЕМНЫЙ АНАЛИЗ

Бегишев В. О., Сопин Э. С., Молчанов Д. А., Самуйлов А. К., Гайдамака Ю. В., Самуйлов К. Е. Оценка эффективности механизма резервирования полосы пропускания для технологии mmWave в сетях связи пятого поколения

УПРАВЛЕНИЕ В МЕДИЦИНЕ И БИОЛОГИИ

Аксенов Ю. В., Добренко Н. В., Ватьян А. С., Капустин Р. О.,

Осипов С. В., Маврин П. Ю., Гусарова Н. Ф., Шалыто А. А.

Применение автоматного подхода для персонализированной

поддержки клинических процессов в медицине

СВЕДЕНИЯ ОБ АВТОРАХ

76

Журнал входит в БД SCOPUS, в RSCI на платформе Web of Science и в Перечень рецензируемых научных изданий, в которых должны быть опубликован основные научные результаты диссертаций на соискание ученой степени кандидата наук, на соискание ученой степени доктора наук.

Сдано в набор 03.09.19. Подписано в печать 15.10.19. Формат 60×841/8. Гарнитура SchoolBookC. Печать цифровая.

Оригинал-макет изготовлен в редакционно-издательском центре ГУАП.

Отпечатано с готовых диапозитивов в редакционно-издательском центре ГУАП.

Журнал распространяется по подписке. Подписку можно оформить в любом отделении связи по каталогу «Пресса России»:
№ 15385 - полугодовой индекс. 


\title{
Hadamard matrices from Goethals - Seidel difference families with a repeated block
}

\author{
L. V. Abuzina, Master Student, orcid.org/0000-0003-0759-7930 \\ N. A. Balonina, Dr. Sc., Professor, orcid.org/0000-0001-7338-4920 \\ D. Ž. Đokovićb ${ }^{\prime}$, Dr. Sc., Distinguished Professor Emeritus, orcid.org/0000-0002-0176-2395, \\ djokovic@uwaterloo.ca
}

I. S. Kotsireasc, Dr. Sc., Professor, orcid.org/0000-0003-2126-8383, ikotsire@wlu.ca

aSaint-Petersburg State University of Aerospace Instrumentation, 67, B. Morskaia St., 190000,

Saint-Petersburg, Russian Federation

bUniversity of Waterloo, Department of Pure Mathematics and Institute for Quantum Computing, Waterloo,

Ontario, N2L 3G1, Canada

'Wilfrid Laurier University, Department of Physics \& Computer Science, Waterloo, Ontario, N2L 3C5, Canada

\begin{abstract}
Purpose: To construct Hadamard matrices by using Goethals - Seidel difference families having a repeated block, generalizing the so called propus construction. In particular we construct the first examples of symmetric Hadamard matrices of order 236. Methods: The main ingredient of the propus construction is a difference family in a finite abelian group of order $v$ consisting of four blocks $\left(X_{1}, X_{2}, X_{3}, X_{4}\right)$ where $X_{1}$ is symmetric and $X_{2}=X_{3}$. The parameters $\left(v ; k_{1}, k_{2}, k_{3}, k_{4} ; \lambda\right)$ of such family must satisfy the additional condition $\sum k_{i}=\lambda+v$. We modify this construction by imposing different symmetry conditions on some of the blocks and construct many examples of Hadamard matrices of this kind. In this paper we work with the cyclic group $Z_{\gamma}$ of order $v$. For larger values of $v$ we build the blocks $X$, by using the orbits of a suitable small cyclic subgroup of the automorphism group of $Z_{v}$. Results: We continue the systematic search for symmetric Hadamard matrices of order $4 v$ by using the propus construction. Such searches were carried out previously for odd $v \leq 51$. We extend it to cover the case $v=53$. Moreover we construct the first examples of symmetric Hadamard matrices of order 236. A wide collection of symmetric and skew-symmetric Hadamard matrices was obtained and the corresponding difference families tabulated by using the symmetry properties of their blocks. Practical relevance: Hadamard matrices are used extensively in the problems of error-free coding, compression and masking of video information. Programs for search of symmetric Hadamard matrices and a library of constructed matrices are used in the mathematical network Internet together with executable on line algorithms.
\end{abstract}

Keywords - symmetric and skew-Hadamard matrices, Goethals - Seidel array, propus array, cyclic difference families.

For citation: Abuzin L. V., Balonin N. A., Đoković D. Ž., Kotsireas I. S. Hadamard matrices from Goethals - Seidel difference families with a repeated block. Informatsionno-upravliaiushchie sistemy [Information and Control Systems], 2019, no. 5, pp. 2-9. doi:10.31799/1684-8853-2019-5-2-9

\section{Introduction}

A Hadamard matrix is a $\{ \pm 1\}$-matrix $\mathbf{H}$ of order $m$ whose rows are mutually orthogonal, i. e. $\mathbf{H H}^{\mathrm{T}}=m \mathbf{I}_{m}$, where $\mathbf{I}_{m}$ is the identity matrix of order $m$ and $\mathrm{T}$ denotes the transposition. We say that $\mathbf{H}$ is a skew-Hadamard matrix if also $\mathbf{H}+\mathbf{H}^{\mathrm{T}}=2 \mathbf{I}_{m}$. The smallest orders $4 v$ for which skew-Hadamard matrices have not been constructed is 276 . Since the size of a Hadamard, skew-Hadamard or symmetric Hadamard matrix can always be doubled, while preserving its type, we are interested mainly in the case where these matrices have order $4 v$ with $v$ odd.

One of the powerful constructions of Hadamard matrices is based on the well-known Goethals Seidel (GS) array. For this construction we need a difference family $\left(X_{1}, X_{2}, X_{3}, X_{4}\right)$ consisting of four subsets $X_{i}$ of a finite abelian group $G$ of order $v$. In addition to the basic condition $\sum k_{i}\left(k_{i}-1\right)=\lambda(v-1)$, $k_{i}=\left|X_{i}\right|$, which the parameters $\left(v ; k_{1}, k_{2}, k_{3}, k_{4} ; \lambda\right)$ of all difference families must satisfy, it is also required that $\sum k_{i}=\lambda+v$. Following [1], we shall refer to the parameter sets and the difference families satisfying this additional condition as $G S$ parameter sets and GS-difference families, respectively. By eliminating $\lambda$ from these two conditions, one obtains that

$$
\sum_{i=1}^{4}\left(v-2 k_{i}\right)^{2}=4 v .
$$

If $v$ is odd and one of the blocks $X_{i}$, say $X_{1}$, is skew then we have $k_{1}=(v-1) / 2$. The meaning of $X_{1}$ being skew is that $G$ is a disjoint union of $X_{1}$, $-X_{1}$ and $\{0\}$. Given such a difference family we can construct skew-Hadamard matrix by plugging the matrices $A_{i}$ associated with the blocks $X_{i}$ into the GS-array. In the case when $G=\mathbf{Z}_{v}$, a cyclic group of order $v$, the $\mathbf{A}_{i}$ are circulant matrices. For instance the first row of $\mathbf{A}_{1}$ is the $\{ \pm 1\}$-sequence $\left(a_{0}, a_{1}, \ldots\right.$, $a_{v-1}$ ) where $a_{i}=-1$ if and only if $i \in X_{1}$. 
Constructing GS-difference families may be a very hard computational problem. For instance no such family is known when $v=167$. However, the problem can be simplified to some extent by selecting a suitable subclass of GS-difference families which possess more structure. One of such subclasses, known as propus difference families has been introduced recently [2] in order to construct symmetric Hadamard matrices. A GS-difference family $\left(X_{1}, X_{2}, X_{3}, X_{4}\right)$ is a propus difference family if one of the blocks is repeated, say $X_{2}=X_{3}$, and at least one of the other two blocks, say $X_{1}$, is symmetric. Recall that $X_{1}$ is symmetric if $-X_{1}=X_{1}$.

In this paper we focus on a larger subclass of GS-difference families, namely the families having one repeated block. We shall assume that $X_{2}=X_{3}$, and consequently $k_{2}=k_{3}$. For convenience we may also assume that all $k_{i} \leq v / 2$. This is justified because replacing a block with its complement in $\mathbf{Z}_{v}$ preserves the property of being a GS-difference family. One can impose further additional symmetry restrictions on some of the blocks in order to make the search easier. For instance we may ask that the block $X_{1}$ be symmetric or skew, or that the repeated block $X_{2}$ be symmetric or skew.

The existence question of propus difference families for odd sizes $v \leq 51$ and all relevant parameter sets was addressed and resolved in the papers [3,4]. The cases where all four $k_{i}$ 's are equal are exceptional and no propus difference families are known except when the $k_{i}$ 's are equal to 3 [4]. In the first section we extend these results to the case $v=53$. The cases $v=55$ and $v=57$ have not been explored so far systematically. However, in both cases one propus difference family is known.

In the case $v=59$ we have constructed six propus difference families. One of them has the parameter set $(59 ; 23,28,28,26 ; 46)$ and the other five nonnequivalent solutions have the parameter set $(59 ; 27,25,25,26$; 44). These solutions are presented in the next section. They are important because they provide the first examples of symmetric Hadamard matrices of order 236. The smallest order $4 v$ for which symmetric Hadamard matrices are not yet known is now 260 (see [2]).

After that, in the subsequent three sections we consider the cases where the block $X_{1}$ is skew, $X_{2}$ is skew, $X_{2}$ is symmetric, respectively.

\section{Propus difference families for $v=53$}

The class of cyclic propus difference families contains an infinite series to which, for simplicity, we refer as the X-series. It is based on the main result of the paper [6] of Xia M., Xia T., Seberry J., and Wu J. These families exist when $4 v-1 \equiv 3(\bmod 8)$ is a prime power. The four circulants $\mathbf{A}_{1}, \mathbf{A}_{2}, \mathbf{A}_{3}=\mathbf{A}_{2}, \mathbf{A}_{4}$ associated with blocks $X_{1}, X_{2}, X_{3}=X_{2}, X_{4}$ of the $X$-series can be plugged into the so called propus array, see (2), to obtain a symmetric Hadamard matrix of order $4 v[2,3,7]$. On the other hand, after a suitable permutation of the blocks, they can be also plugged into the GS-array to obtain a skew-Hadamard matrix of the same order.

For $v=53$ there are three propus parameter sets, but there are six essentially different choices for selecting the symmetric and the repeated blocks. Below we list the solutions (i. e., propus difference families) for each of these six choices. In all cases the block $X_{1}$ is symmetric and $X_{2}=X_{3}$, and so we list only the three blocks $X_{1}, X_{2}, X_{4}$ in that order. The first solution belongs to the $X$-series.

$(53 ; 23,22,22,26 ; 40)$

$\{0, \pm 1, \pm 3, \pm 9, \pm 10, \pm 12, \pm 14, \pm 16, \pm 17, \pm 20, \pm 23, \pm 25\}$

$\{0,1,2,3,9,11,18,21,24,25,29,33,34,35,36,41,44,46,48,49,50,52\}$

$\{1,5,6,10,11,12,15,18,22,27,28,29,30,32,33,34,36,37,39,40,44,45,46,49,50,51\}$

$(53 ; 26,22,22,23 ; 40)$

$\{ \pm 1, \pm 7, \pm 9, \pm 10, \pm 12, \pm 14, \pm 17, \pm 18, \pm 19, \pm 20, \pm 21, \pm 24, \pm 25\}$

$\{7,11,13,14,16,18,19,20,24,26,27,28,30,31,36,41,42,44,45,48,50,51\}$

$\{0,5,9,11,12,13,18,22,23,25,31,32,33,36,37,38,41,43,45,48,49,50,52\}$

$(53 ; 24,25,25,20 ; 41)$

$\{ \pm 4, \pm 7, \pm 9, \pm 10, \pm 13, \pm 14, \pm 15, \pm 16, \pm 19, \pm 22, \pm 24, \pm 26\}$

$\{1,6,7,8,9,16,17,21,22,23,25,27,30,33,34,35,37,38,39,40,41,44,48,50,52\}$

$\{1,2,9,10,13,17,18,22,23,29,36,39,42,43,45,47,48,50,51,52\}$

$(53 ; 20,25,25,24 ; 41)$

$\{ \pm 2, \pm 4, \pm 6, \pm 10, \pm 13, \pm 16, \pm 19, \pm 20, \pm 21, \pm 23\}$

$\{0,1,3,4,5,9,15,16,17,18,23,24,25,28,31,33,36,37,42,45,46,47,49,51,52\}$

$\{1,3,4,8,11,12,14,15,16,24,27,29,34,39,40,42,43,45,46,47,49,50,51,52\}$ 
$(53 ; 24,22,22,24 ; 39)$

$\{ \pm 2, \pm 6, \pm 8, \pm 10, \pm 11, \pm 12, \pm 14, \pm 15, \pm 17, \pm 21, \pm 22, \pm 24\}$

$\{0,3,10,11,19,20,21,22,23,24,26,28,31,34,35,37,39,40,41,45,46,50\}$

$\{6,7,10,11,12,14,16,17,19,22,24,27,28,31,36,37,39,43,44,45,49,50,51,52\}$

$(53 ; 22,24,24,22 ; 39)$

$\{ \pm 7, \pm 8, \pm 10, \pm 12, \pm 14, \pm 15, \pm 17, \pm 18, \pm 23, \pm 24, \pm 26\}$

$\{1,2,3,8,10,12,13,14,15,16,17,19,22,23,29,31,32,33,37,39,42,43,47,50\}$

$\{2,6,7,12,14,19,23,25,26,29,31,34,37,38,39,41,42,46,49,50,51,52\}$

\section{Six symmetric Hadamard matrices of order 236}

As $236=4 \cdot 59$ we set $v=59$. Define the subsets $X_{1}, X_{2}, X_{3}, X_{4}$ of $\mathbf{Z}_{v}$ by:

$X_{1}=\{0, \pm 1, \pm 4, \pm 5, \pm 7, \pm 8, \pm 11, \pm 14, \pm 20, \pm 25, \pm 28, \pm 29\}$,

$X_{2}=X_{3}=\{4,5,7,11,12,16,17,24,25,26,27,28,29,33,34,37,39,40,42,43,44,45,47,49,51,53,56,58\}$,

$X_{4}=\{2,3,10,12,13,14,16,18,19,26,28,29,36,38,39,40,42,44,46,47,49,50,53,54,55,57\}$.

One can easily verify that these four blocks form a difference family in $\mathbf{Z}_{v}$ with parameters $(59 ; 23,28,28$, $26 ; 46)$. The four circulants $\mathbf{A}_{1}, \mathbf{A}_{2}, \mathbf{A}_{3}, \mathbf{A}_{4}$ of order 59 associated with the blocks $X_{1}, X_{2}, X_{3}, X_{4}$ respectively can be plugged into the propus array

$$
\left[\begin{array}{cccc}
-\mathbf{A}_{1} & \mathbf{A}_{2} \mathbf{R} & \mathbf{A}_{3} \mathbf{R} & \mathbf{A}_{4} \mathbf{R} \\
\mathbf{A}_{3} \mathbf{R} & \mathbf{R} \mathbf{A}_{4} & \mathbf{A}_{1} & -\mathbf{R A}_{2} \\
\mathbf{A}_{2} \mathbf{R} & \mathbf{A}_{1} & -\mathbf{R} \mathbf{A}_{4} & \mathbf{R A}_{3} \\
\mathbf{A}_{4} \mathbf{R} & -\mathbf{R} \mathbf{A}_{3} & \mathbf{R A}_{2} & \mathbf{A}_{1}
\end{array}\right],
$$

where

$$
\mathbf{R}=\left[\begin{array}{ccccc}
0 & 0 & \cdots & 0 & 1 \\
0 & 0 & & 1 & 0 \\
\vdots & & & & \\
0 & 1 & & 0 & 0 \\
1 & 0 & & 0 & 0
\end{array}\right]
$$

to obtain the desired symmetric Hadamard matrix of order 236.

For the parameter set $(59 ; 27,25,25,26 ; 44)$ we have constructed the following five nonequivalent difference families. As in the previous section we list only the blocks $X_{1}, X_{2}, X_{4}$. In each case the block $X_{1}$ is obviously symmetric.

$\{0, \pm 2, \pm 4, \pm 7, \pm 8, \pm 12, \pm 13, \pm 15, \pm 16, \pm 17, \pm 18, \pm 20, \pm 23, \pm 29\}$

$\{1,2,4,5,12,13,17,19,20,21,22,23,26,27,31,35,37,38,40,44,47,49,50,55,57\}$

$\{3,7,12,13,14,16,18,19,20,22,23,24,25,26,31,32,33,34,36,38,43,45,46,50,51,53\}$

$\{0, \pm 2, \pm 4, \pm 5, \pm 6, \pm 7, \pm 9, \pm 10, \pm 11, \pm 12, \pm 20, \pm 21, \pm 26, \pm 29\}$

$\{1,4,5,8,9,11,15,18,19,20,21,23,26,29,31,35,36,38,41,42,43,44,49,51,55\}$

$\{1,2,4,5,7,9,11,13,14,15,21,23,28,32,33,34,35,36,37,39,44,45,49,50,53,57\}$

$\{0, \pm 1, \pm 5, \pm 8, \pm 11, \pm 12, \pm 13, \pm 17, \pm 21, \pm 22, \pm 23, \pm 27, \pm 28, \pm 29\}$

$\{1,2,3,5,6,9,10,12,14,15,17,20,27,30,34,41,42,43,45,46,47,48,50,52,54\}$

$\{2,4,5,6,8,12,15,17,20,23,25,28,29,31,35,40,41,42,43,44,49,51,52,54,57,58\}$

$\{0, \pm 4, \pm 6, \pm 7, \pm 10, \pm 12, \pm 13, \pm 15, \pm 16, \pm 18, \pm 20, \pm 25, \pm 26, \pm 29\}$

$\{2,4,6,10,11,15,16,17,18,19,21,26,27,28,29,30,33,35,36,42,53,54,56,57,58\}$

$\{3,6,7,8,9,13,18,19,21,23,24,26,28,29,33,34,36,37,41,43,47,50,51,54,56,58\}$ 
$\{0, \pm 1, \pm 2, \pm 7, \pm 12, \pm 17, \pm 18, \pm 19, \pm 21, \pm 23, \pm 25, \pm 26, \pm 27, \pm 29\}$

$\{2,5,7,13,14,15,17,23,24,25,28,29,32,35,39,41,44,45,46,48,49,51,52,53,58\}$

$\{1,2,4,6,7,15,20,21,23,25,31,32,34,35,37,38,39,43,46,47,48,50,52,53,57,58\}$

As in the first example of this section, these propus difference families give five symmetric Hadamard matrices of order 236 .

\section{Difference families with $X_{1}$ skew}

In the case when $X_{1}$ is skew $v$ must be odd, $k_{1}=(v-1) / 2$ and the parameter set will be written as

$$
\left(v ; k_{1}=(v-1) / 2, k_{2}, k_{3}=k_{2}, k_{4} ; \lambda\right) \text {. }
$$

Further we have

$$
2 k_{2}+k_{4}=\lambda+(v+1) / 2
$$

and

$$
\left(v-2 k_{4}\right)^{2}+2\left(v-2 k_{2}\right)^{2}=4 v-1
$$

Without any loss of generality, we impose the following additional restriction:

$$
v / 2 \geq k_{2}, k_{4}
$$

We conjecture that for each parameter set (3) there exists at least one difference family $\left(X_{1}, X_{2}, X_{3}=X_{2}\right.$, $\left.X_{4}\right)$ in $\mathbf{Z}_{v}$ with these parameters and with $X_{1}$ skew.

There exist positive odd integers $v$ for which there is no parameter set of the form (3). For instance, this is the case for $v=9,23,29,39,49,51,59$. More precisely, it was proved by Gauss [8] that the Diophantine equation $a^{2}+2 b^{2}=m$, where $m$ is a positive integer, has a solution with $a$ and $b$ relatively prime if and only if -2 is a square in $\mathbf{Z}_{m}$.

For odd $v<50$, we list in Tables 1-3 all parameter sets (3) which satisfy the conditions (4) and (6). There are in total 27 such parameter sets (12 of them arise from the $X$-series). For each of them we have recorded in Tables 1-3 at least one difference family with $X_{1}$ skew and $X_{2}=X_{3}$. Thus our conjecture has been verified for $v<50$. The block $X_{4}$ is symmetric in Table 1 , skew in Table 2 , and neither symmetric nor skew in Table 3 . In Table 1 the symbol $X$ indicates that the parameter set belongs to the $X$-series.

In some cases we build the base blocks $X_{i}$ from the orbits of a subgroup, $H$, of the group of the invertible elements, $\mathbf{Z}_{v}^{*}$, of the ring $\mathbf{Z}_{v}$. In such cases our choice for $H$ is always a cyclic subgroup $\langle s\rangle$, with generator $s$, and we show it below the corresponding parameter set. In these cases, instead of listing all elements of the $X_{i}$ we list (in square brackets) only the representatives of the orbits of $H$ contained in $X_{i}$.

One of the blocks of difference families in the $X$-series is symmetric and we have endevoured to find such solutions in other cases as well. In some cases, exaustive computer searches showed that such solutions do not exist.

The second solution given above for the case $v=7$ gives a positive answer to a question raised in [6, p. 503]. Indeed the polynomials

$$
\begin{gathered}
f_{1}(\zeta)=\zeta-\zeta^{2}-\zeta^{3}+\zeta^{4}+\zeta^{5}-\zeta^{6} ; \\
f_{2}(\zeta)=1+\zeta+\zeta^{2}-\zeta^{3}-\zeta^{4}+\zeta^{5}+\zeta^{6} ; \\
f_{3}(\zeta)=-1+\zeta-\zeta^{2}+\zeta^{3}+\zeta^{4}+\zeta^{5}+\zeta^{6} ; \\
f_{4}(\zeta)=f_{3}(\zeta)
\end{gathered}
$$

satisfy the conditions (16) and (17) of the cited paper [6] as well as

$$
f(1)^{2}=0, f_{2}(1)^{2}=f_{3}(1)^{2}=f_{4}(1)^{2}=9 \text {. }
$$

If both $X_{2}=X_{3}$ and $X_{4}$ are skew then the parameter set must have the form

$$
\left(v=2 s^{2}+2 s+1 ; s^{2}+s, s^{2}, s^{2}, s^{2}+s ; \lambda=2 s^{2}-1\right) ; s=1,2,3, \ldots
$$


Table 1. $X_{1}$ skew, $X_{2}=X_{3}$, and $X_{4}$ symmetric

\begin{tabular}{|c|c|c|}
\hline$(3 ; 1,1,1,0 ; 0)$ & $X$ & $\{1\}\{0\} \emptyset$ \\
\hline$(5 ; 2,1,1,2 ; 1)$ & $X$ & $\{1,2\}\{0\}\{ \pm 2\}$ \\
\hline$(7 ; 3,3,3,1 ; 3)$ & $X$ & $\{1,2,4\}\{0,1,3\}\{0\}$ \\
\hline$(7 ; 3,2,2,2 ; 2)$ & & $\{2,3,6\}\{0,2\}\{ \pm 3\}$ \\
\hline$(11 ; 5,4,4,3 ; 5)$ & $X$ & $\{1,2,4,6,8\}\{0,1,2,5\}\{0, \pm 3\}$ \\
\hline$(13 ; 6,6,6,3 ; 8)$ & & $\{1,2,3,4,7,8\}\{0,1,2,6,9,11\}\{0, \pm 3\}$ \\
\hline$(13 ; 6,4,4,6 ; 7)$ & & $\{1,2,3,5,6,9\}\{0,1,3,9\}\{ \pm 1, \pm 3, \pm 4\}$ \\
\hline$(15 ; 7,5,5,6 ; 8)$ & $X$ & $\{2,4,5,6,7,12,14\}\{2,5,6,9,11\}\{ \pm 2, \pm 6, \pm 7\}$ \\
\hline$(17 ; 8,7,7,5 ; 10)$ & $X$ & $\{1,2,3,5,9,10,11,13\}\{0,3,7,9,12,13,14\}\{0, \pm 2, \pm 3\}$ \\
\hline$(19 ; 9,7,7,7 ; 11)$ & & $\begin{array}{l}\{1,2,3,7,10,11,13,14,15\}\{4,5,9,11,13,14,17\} \\
\{0, \pm 2, \pm 3, \pm 5\}\end{array}$ \\
\hline$(21 ; 10,10,10,6 ; 15)$ & $X$ & $\begin{array}{l}\{1,3,4,6,7,8,9,10,16,19\}\{0,4,5,7,8,9,11,13,18,19\} \\
\{ \pm 3, \pm 4, \pm 8\}\end{array}$ \\
\hline$(25 ; 12,11,11,8 ; 17)$ & & $\begin{array}{l}\{1,2,3,5,7,8,10,11,12,16,19,21\} \\
\{1,3,9,10,11,13,14,15,16,20,23\}\{ \pm 1, \pm 5, \pm 8, \pm 9\}\end{array}$ \\
\hline$(27 ; 13,10,10,12 ; 18)$ & $X$ & $\begin{array}{l}\{2,3,5,6,8,13,15,16,17,18,20,23,26\} \\
\{3,4,9,11,14,18,20,22,23,24\} \\
\{ \pm 3, \pm 7, \pm 8, \pm 11, \pm 12, \pm 13\}\end{array}$ \\
\hline $\begin{array}{l}(31 ; 15,12,12,13 ; 21) \\
\langle 5\rangle\end{array}$ & & {$[6,8,11,12,16][2,8,16,17][0,3,4,11,16]$} \\
\hline$(33 ; 16,14,14,12 ; 23)$ & $X$ & $\begin{array}{l}\{1,4,8,12,14,17,18,20,22,23,24,26,27,28,30,31\} \\
\{3,5,6,9,10,11,12,14,17,22,23,24,27,32\} \\
\{ \pm 3, \pm 4, \pm 5, \pm 12, \pm 14, \pm 16\}\end{array}$ \\
\hline$(35 ; 17,16,16,12 ; 26)$ & $X$ & $\begin{array}{l}\{2,3,5,7,8,9,10,11,13,14,15,18,19,23,29,31,34\} \\
\{0,1,3,5,8,9,16,17,18,19,23,25,28,30,31,34\} \\
\{ \pm 5, \pm 6, \pm 7, \pm 9, \pm 12, \pm 16\}\end{array}$ \\
\hline$(41 ; 20,16,16,20 ; 31)$ & & $\begin{array}{l}\{1,4,6,7,9,11,13,14,18,19,20,24,25,26,29,31,33,36,38,39\} \\
\{4,6,9,12,13,14,17,18,25,26,28,29,30,32,35,39\} \\
\{5,7,8,9,13,15,16,17,18,19,22,23,24,25,26,28,32,33,34,36\}\end{array}$ \\
\hline$(45 ; 22,19,19,18 ; 33)$ & $X$ & $\begin{array}{l}\{3,4,8,11,13,14,15,17,18,20,21,23,26,29,33,35,36,38,39,40,43,44\} \\
\{2,4,6,7,8,9,12,15,18,19,20,22,23,24,26,31,32,33,41\} \\
\{ \pm 1, \pm 4, \pm 5, \pm 6, \pm 12, \pm 13, \pm 16, \pm 18, \pm 20\}\end{array}$ \\
\hline
\end{tabular}

Table 2. $X_{1}$ and $X_{4}$ skew and $X_{2}=X_{3}$

\begin{tabular}{|l|c|c|l|}
\hline$s$ & $v$ & Subgroup & \multicolumn{1}{|c|}{$X_{1} X_{2} X_{4}$} \\
\hline 1 & 5 & $\langle 1\rangle$ & $\{1,2\}\{0\}\{1,3\}$ \\
\hline 2 & 13 & $\langle 3\rangle$ & {$[2,4][0,2][1,2]$} \\
\hline 3 & 25 & $\langle 1\rangle$ & $\begin{array}{l}\{1,2,3,5,6,7,12,14,15,16,17,21\} \\
\{1,5,9,12,13,15,18,19,21\} \\
\{2,3,4,5,7,9,10,11,12,17,19,24\}\end{array}$ \\
\hline 4 & 41 & & {$[1,2,11,15][0,1,4,11][1,5,6,11]$} \\
\hline 5 & 61 & $\langle 10\rangle$ & {$[1,2,4,10,13,23][1,5,8,12,13][1,4,6,8,13,26]$} \\
\hline 6 & 85 & $\langle 9\rangle$ & $?$ \\
\hline 7 & 113 & $?$ & $?$ \\
\hline
\end{tabular}


Table 3. $X_{1}$ skew and $X_{2}=X_{3}$

\begin{tabular}{|c|c|}
\hline$(25 ; 12,10,10,9 ; 16)$ & $\begin{array}{l}\{1,3,4,5,7,8,9,13,14,15,19,23\}\{1,3,5,8,10,11,13,14,21,22\} \\
\{5,6,7,8,11,14,15,18,20\}\end{array}$ \\
\hline \multicolumn{2}{|l|}{$(31 ; 15,15,15,10 ; 24)$} \\
\hline$\langle 5\rangle$ & {$[2,6,8,11,16][1,2,3,4,6][0,2,4,11]$} \\
\hline \multicolumn{2}{|l|}{$(37 ; 18,15,15,15 ; 26)$} \\
\hline$\langle 10\rangle$ & {$[3,6,11,17,18,21][1,3,11,14,18][6,7,11,14,17]$} \\
\hline \multicolumn{2}{|l|}{$(43 ; 21,21,21,15 ; 35)$} \\
\hline$\langle 6\rangle$ & {$[1,3,4,13,14,20,26][1,2,5,10,13,19,20][1,14,19,20,26]$} \\
\hline \multicolumn{2}{|l|}{$(43 ; 21,19,19,16 ; 32)$} \\
\hline$\langle 6\rangle$ & {$[1,5,9,10,14,19,21][0,1,7,9,10,13,19][0,3,4,7,13,20]$} \\
\hline$(43 ; 21,17,17,20 ; 32)$ & $\begin{array}{l}\{1,4,5,6,7,11,14,15,19,21,23,25,26,27,30,31,33,34,35,40,41\} \\
\{2,4,7,9,10,13,15,20,21,22,24,25,29,32,34,35,41\} \\
\{0,5,6,8,10,17,18,19,20,21,22,23,24,25,26,27,30,34,35,41\}\end{array}$ \\
\hline$(47 ; 23,22,22,17 ; 37)$ & $\begin{array}{l}\{1,4,5,9,10,12,17,18,19,21,22,24,27,31,32,33,34,36,39,40,41,44,45\} \\
\{4,5,6,9,12,20,21,22,23,25,28,30,31,32,34,36,38,40,41,42,45,46\} \\
\{0,2,4,5,9,16,18,19,21,22,23,24,25,28,31,38,43\}\end{array}$ \\
\hline$(47 ; 23,19,19,21 ; 35)$ & $\begin{array}{l}\{2,3,4,6,7,9,14,17,18,19,23,25,26,27,31,32,34,35,36,37,39,42,46\} \\
\{0,2,4,12,14,17,20,21,25,27,28,34,37,38,39,40,43,45,46\} \\
\{1,3,4,5,7,8,10,11,12,14,19,20,24,25,34,35,39,40,41,43,45\}\end{array}$ \\
\hline
\end{tabular}

For the first five values of $s$, difference families with these parameters exist. They are shown in Table 2.

Table 3 covers the cases where we could not find solutions with $X_{4}$ symmetric or skew.

\section{Difference families with $X_{2}=X_{3}$ skew}

We list here the difference families with the repeated block $X_{2}=X_{3}$ skew. A necessary condition for the existence of such families is that $2 v-1$ must be a sum of two squares. This follows from the equation (1). We assume that $k_{1} \geq k_{4}$. In the second col- umn we indicate the symmetry types of the blocks $X_{1}, X_{2}$ and $X_{4}$. The letter "s" means that the block is symmetric and " $\mathrm{k}$ " means that it is skew. The letter " $x$ " means that, in the given solution, the corresponding block is neither symmetric nor skew. The question mark indicates that the existence question remains undecided.

If $v$ is a prime number $\equiv 3(\bmod 4)$ and if there exists a D-optimal design $\left(X_{1}, X_{4}\right)$ with parameters $\left(v ; k_{1}, k_{4} ; \lambda=k_{1}+k_{4}-(v-1) / 2\right)$ then we can take $X_{2}=X_{3}$ to be the Legendre difference set to obtain the desired difference family $\left(X_{1}, X_{2}, X_{3}, X_{4}\right)$. For an example see the difference family for $(43 ; 21,21,21$, $15 ; 35)$ in Table 4 . Solutions where $\left(X_{1}, X_{4}\right)$ is not a

Table 4. $X_{2}$ skew and $X_{2}=X_{3}$

\begin{tabular}{|l|l|l|}
\hline$(3 ; 1,1,1,0 ; 0)$ & $(\mathrm{kks})$ & $\{1\}\{1\} \emptyset$ \\
\hline$(5 ; 1,2,2,1 ; 1)$ & $(\mathrm{xkx})$ & No \\
\hline$(7 ; 3,3,3,1 ; 3)$ & $(\mathrm{kks})$ & $\{3,5,6\}\{3,5,6\}\{0\}$ \\
\hline$(9 ; 3,4,4,2 ; 4)$ & $(\mathrm{xkx})$ & No \\
\hline$(13 ; 6,6,6,3 ; 8)$ & $(\mathrm{skx})$ & $\begin{array}{l}\{ \pm 2, \pm 5, \pm 6\}\{2,4,5,6,10,12\}\{0,1,4\} \\
\{4,7,8,10,11,12\}\{1,3,7,8,9,11\}\{0,3,12\}\end{array}$ \\
\hline$(13 ; 4,6,6,4 ; 7)$ & $(\mathrm{skx})$ & $\{ \pm 1, \pm 2\}\{1,3,7,8,9,11\}\{0,1,6,10\}$ \\
\hline$(15 ; 6,7,7,4 ; 9)$ & $(\mathrm{xkx})$ & No \\
\hline
\end{tabular}


Table 4 (compl.)

\begin{tabular}{|c|c|c|}
\hline$(19 ; 7,9,9,6 ; 12)$ & $(\mathrm{xks})$ & $\begin{array}{l}\{0,5,8,10,11,12,14\}\{2,3,8,10,12,13,14,15,18\} \\
\{ \pm 1, \pm 7, \pm 8\}\end{array}$ \\
\hline$(21 ; 10,10,10,6 ; 15)$ & $(\mathrm{xkx})$ & $\begin{array}{l}\{1,3,7,9,13,14,15,16,19,20\}\{1,7,8,10,12,15,16,17,18,19\} \\
\{0,4,7,12,17,20\}\end{array}$ \\
\hline$(23 ; 10,11,11,7 ; 16)$ & $(\mathrm{xkx})$ & $\begin{array}{l}\{0,1,4,5,6,8,11,12,14,22\}\{5,7,10,11,14,15,17,19,20,21,22\} \\
\{7,8,11,15,17,20,22\}\end{array}$ \\
\hline$(25 ; 9,12,12,9 ; 17)$ & $(\mathrm{xkx})$ & $\begin{array}{l}\{4,7,9,11,15,16,17,21,22\}\{1,2,3,4,5,7,9,10,13,14,17,19\} \\
\{1,4,7,8,10,15,18,19,24\}\end{array}$ \\
\hline$(27 ; 11,13,13,9 ; 19)$ & $(\mathrm{xkx})$ & $\begin{array}{l}\{0,1,4,8,10,13,14,15,21,23,25\} \\
\{4,5,8,13,15,16,17,18,20,21,24,25,26\} \\
\{0,2,8,11,13,14,15,17,20\}\end{array}$ \\
\hline $\begin{array}{l}(31 ; 15,15,15,10 ; 24) \\
\langle 5\rangle\end{array}$ & $(\mathrm{kkx})$ & {$[1,3,8,11,12][1,2,3,8,11][0,4,11,17]$} \\
\hline$(33 ; 15,16,16,11 ; 25)$ & $(\mathrm{xkx})$ & No \\
\hline$(33 ; 13,16,16,12 ; 24)$ & $(\mathrm{xkx})$ & No \\
\hline$(37 ; 16,18,18,13 ; 28)$ & $(\mathrm{xkx})$ & $?$ \\
\hline$(41 ; 16,20,20,16 ; 31)$ & $(\mathrm{xkx})$ & $?$ \\
\hline$(43 ; 21,21,21,15 ; 35)$ & $(\mathrm{xkx})$ & $\begin{array}{l}\{0,1,2,3,4,5,6,7,11,12,13,14,17,20,24,25,28,30,31,34,39\} \\
\{2,3,5,7,8,12,18,19,20,22,26,27,28,29,30,32,33,34,37,39,42\} \\
\{0,2,3,4,7,9,12,14,16,22,24,30,31,34,39\}\end{array}$ \\
\hline $\begin{array}{l}(43 ; 18,21,21,16 ; 33) \\
\langle 6\rangle\end{array}$ & $(\mathrm{xkx})$ & $\begin{array}{l}{[2,7,10,14,20,26][1,4,9,10,13,14,21]} \\
{[0,4,13,14,20,26]}\end{array}$ \\
\hline$(45 ; 21,22,22,16 ; 36)$ & $(\mathrm{xkx})$ & $?$ \\
\hline$(49 ; 22,24,24,18 ; 39)$ & $(\mathrm{xkx})$ & $?$ \\
\hline
\end{tabular}

DO-design may also exist, as an example see the difference family for $(43 ; 18,21,21,16 ; 33)$ in Table 4.

\section{Difference families with $X_{2}=X_{3}$ symmetric}

The difference families $\left(X_{1}, X_{2}, X_{3}, X_{4}\right)$ in $\mathbf{Z}_{v}$, $v$ odd, associated with the Williamson matrices in

- Table 5. $X_{2}$ symmetric and $X_{2}=X_{3}$

\begin{tabular}{|l|l|l|}
\hline $\begin{array}{l}(13 ; 6,6,6, \\
3 ; 8)\end{array}$ & (xsx) & $\begin{array}{l}\{0,2,3,6,11,12\}\{1, \pm 3, \pm 4\} \\
\{0,1,4\}\end{array}$ \\
\hline $\begin{array}{l}(13 ; 4,6,6, \\
4 ; 7)\end{array}$ & (ssx) & $\{ \pm 3, \pm 5\}\{ \pm 2, \pm 5, \pm 6\}\{0,1,5,7\}$ \\
\hline $\begin{array}{l}(23 ; 10,11, \\
11,7 ; 16)\end{array}$ & (xsx) & $\begin{array}{l}\{0,1,3,5,8,12,14,15,17,20\} \\
\{0, \pm 1, \pm 2, \pm 4, \pm 8, \pm 9\} \\
0,2,4,5,9,12,13\}\end{array}$ \\
\hline
\end{tabular}

the well-known Turyn series [9] have the following properties. After a suitable permutation of the $X_{i}$, we have $X_{1}=\{0\} \cup X_{4}, X_{2}=X_{3}$ and all $X_{i}$ are symmetric. They exist whenever $q=2 v-1 \equiv$ $\equiv 1(\bmod 4)$ is a prime power. Apart from this series, for odd $v<30$ we found only three additional cyclic GS-difference families $\left(X_{1}, X_{2}, X_{3}, X_{4}\right)$ having a repeated block $X_{2}=X_{3}$ which is symmetric (see Table 5).

\section{Acknowledgements}

The research of the second author leading to these results has received funding from the Ministry of Education and Science of the Russian Federation according to the project part of the state funding assignment No 2.2200.2017/4.6. The research of the last two authors was enabled in part by SHARCNET (http://www.sharcnet.ca) and Compute Canada (http://computecanada.ca). 


\section{References}

1. Đoković D. Ž., Kotsireas I. S. Goethals - Seidel difference families with symmetric or skew base blocks. Mathematics in Computer Science, 2018, vol. 12(4), pp. 373-388.

2. Seberry J., Balonin N. A. The propus construction for symmetric Hadamard matrices. Australasian Journal of Combinatorics, 2017, no. 69(3), pp. 349-357.

3. Balonin N. A., Balonin Y. N., Đoković D. Ž., Karbovskiy D. A., Sergeev M. B. Construction of symmetric Hadamard matrices. Informatsionno-upravliaiush chie sistemy [Information and Control Systems], 2017, no. 5, pp. 2-11. doi:10.15217/issn1684-8853.2017.5.2

4. Balonin N. A., Đoković D. Ž., Karbovskiy D. A. Construction of symmetric Hadamard matrices of order $4 v$ for $v=47,73,113$. Spec. Matrices, 2018, vol. 6, iss. 1, pp. 11-22.
5. Balonin N. A., Đoković D. Ž. Symmetric Hadamard matrices of orders 268, 412, 436 and 604. Informatsionno-upravliaiushchie sistemy [Information and Control Systems], 2018, no. 4, pp. 2-8. doi:10.31799/ 1684-8853-2018-4-2-8

6. Xia M., Xia T., Seberry J. and Wu J. An infinite series of Goethals - Seidel arrays. Discrete Applied Mathematics, 2005, no. 145, pp. 498-504.

7. Di Mateo O., Đoković D. Ž., Kotsireas I. S. Symmetric Hadamard matrices of order 116 and 172 exist. Spec. Matrices, 2015, no. 3, pp. 227-234.

8. Gauss Carl Friedrich. Trudy po teorii chisel [Proceedings in Number Theory]. Ed. of I. M. Vinogradov, Moscow, AN SSSR Publ., 1959. 979 p. (In Russian).

9. Turyn R. J. An infinite class of Williamson matrices. Journal Combinatorial Theory, Ser. A, 1972, no. 12, pp. 319-321.

УДК 519.614

doi:10.31799/1684-8853-2019-5-2-9

Матрицы Адамара разностного семейства Гетхальса - Зейделя с повторяющимся блоком

Л. В. Абузин ${ }^{\mathrm{a}}$, магистрант, orcid.org/0000-0003-0759-7930

Н. А. Балонин ${ }^{\text {a }}$, доктор наук, профессор, orcid.org/0000-0001-7338-4920

Д. Ж. Джокович ${ }^{\sigma}$, доктор наук, профессор, orcid.org/0000-0002-0176-2395, djokovic@uwaterloo.ca

И. С. Котсирис ${ }^{\mathrm{B}}$ доктор наук, профессор, orcid.org/0000-0003-2126-8383, ikotsire@wlu.ca

а Санкт-Петербургский государственный университет аэрокосмического приборостроения, Б. Морская ул., 67 , 190000, Санкт-Петербург, РФ

бУниверситет Ватерлоо, Ватерлоо, Онтарио, N2L 3G1, Канада

вУниверситет Уилфрида Лорье, Ватерлоо, Онтарио, N2L 3C5, Канада

Цель: построить матрицы Адамара, описываемые разностными семействами Гетхальса - Зейделя с повторяющимися блоками, посредством обобщения так называемой пропус-конструкции. Методы: основная составляющая конструкции пропусов - разностное семейство конечной абелевой группы порядка $v$, содержащее четыре блока $\left(X_{1}, X_{2}, X_{3}, X_{4}\right)$, где $X_{1}$ симметричен и $X_{2}=X_{3}$. Параметры $\left(v ; k_{1}, k_{2}, k_{3}, k_{4} ; \lambda\right)$ такого семейства должны удовлетворять дополнительному условию $\sum k_{i}=\lambda+v$. Эта конструкция модифицирована использованием различных типов симметрий выбираемых блоков и конструированием разнообразных примеров матриц Адамара такого сорта. В этой статье работа велась с циклической группой $\mathbf{Z}_{v}$ порядка $v$. Для больших значений $v$ построены блоки $X_{i}$ посредством орбит подходящих малых циклических подгрупп группы автоморфизмов Z должен систематический поиск симметричных матриц Адамара порядка $4 v$, использующий пропус-конструкцию. Аналогичные исследования проведены ранее для нечетных значений $v \leq 51$. Мы расширяем итог, закрывая случай $v=53$. Кроме того, сконструированы первые примеры симметричных матриц Адамара порядка 236. Получена обширная коллекция симметричных и кососимметричных матриц Адамара, и соответствующие разностные семейства классифицированы на основе видов симметрий их блоков. Практическое значение: матрицы Адамара имеют непосредственное практическое значение для задач помехоустойчивого кодирования, сжатия и маскирования видеоинформации. Программное обеспечение нахождения симметричных матриц Адамара и библиотека найденных матриц используются в математической сети Интернет с исполняемыми онлайн алгоритмами.

Ключевые слова - симметричные и кососимметричные матрицы Адамара, массив Гетхальса - Зейделя, массив пропус, циклические разностные семейства.

Для цитирования: Abuzin L. V., Balonin N. A., Đoković D. Ž., Kotsireas I. S. Hadamard matrices from Goethals — Seidel difference families with a repeated block. Инфорлационно-управляющие систель, 2019, № 5, с. 2-9. doi:10.31799/1684-8853-2019-5-2-9

For citation: Abuzin L. V., Balonin N. A., Đoković D. Ž., Kotsireas I. S. Hadamard matrices from Goethals - Seidel difference families with a repeated block. Informatsionno-upravliaiushchie sistemy [Information and Control Systems], 2019 , no. 5, pp. 2-9. doi:10.31799/1684-8853-2019-5-2-9 


\title{
Возможности рекуррентных нейронных сетей с управляемыми әлементами по восстановлению потоков кадров
}

\author{
В. Ю. Осипова, доктор техн. наук, профессор, orcid.org/0000-0001-5905-4415, osipov_vasiliy@mail.ru \\ В. В. Никифорова, доктор техн. наук, профессор, orcid.org/0000-0002-6836-6303 \\ а Санкт-Петербургский институт информатики и автоматизации РАН, 14-я линия В. O., 39, \\ Санкт-Петербург, 199178, РФ
}

Постановка проблемы: в условиях различных мешающих воздействий остро стоят вопросы оперативного восстановления потоков искаженных кадров. При этом требуется учитывать предысторию и динамику законов измерения событий. Традиционные методы восстановления потоков искаженных кадров не в полной мере учитывают особенности этого процесса. Цель: исследование возможностей рекуррентных нейронных сетей с управляемыми элементами по восстановлению потоков кадров. Результаты: предложено оценивать потенциал рекуррентных нейронных сетей с управляемыми элементами по числу успешных вариантов восстановления искаженной последовательности кадров. Оценка возможностей этих нейронных сетей по введенному показателю продемонстрировала высокую их зависимость от вида структуры сетей и параметров настройки. В лучшую сторону отличаются рекуррентные нейронные сети со спиральными структурами слоев. С увеличением числа витков спирали растут и возможности сетей. Повышение возможностей сетей по восстановлению потоков искаженных кадров осуществимо при переходе от униполярных к биполярным функциям весов синапсов нейронов. Существенное увеличение возможностей исследуемых нейронных сетей возможно за счет управления порогами возбуждения нейронов для реализации последовательного, а не параллельного устранения различных видов ошибок. В отличие от известных нейронных сетей рекуррентные нейронные сети с управляемыми элементами позволяют адаптироваться к изменениям законов, свойственных потокам кадров, реализовывать управляемую ассоциативную обработку сигналов. Проведенные эксперименты показали, что эти нейронные сети за счет ассоциативных связей могут учитывать глубокий текущий опыт обработки сигналов и успешно применяться для восстановления потоков искаженных кадров.

Ключевые слова - потоки искаженных кадров, восстановление, рекуррентная нейронная сеть, логическая структура, управление, оценка.

Для цитирования: Осипов В. Ю., Никифоров В. В. Возможности рекуррентных нейронных сетей с управляемыми элементами по восстановлению потоков кадров. Инфорлационно-управляющие систель, 2019, № 5, с. 10-17. doi:10.31799/1684-8853-2019-5-10-17 For citation: Osipov V. Yu., Nikiforov V. V. Recurrent neural networks with controlled elements in restoring frame flows. Informatsionnoupravliaiushchie sistemy [Information and Control Systems], 2019, no. 5, pp. 10-17 (In Russian). doi:10.31799/1684-8853-2019-5-10-17

\section{Введение}

Одной из актуальных задач обработки потоков кадров в условиях мешающих воздействий выступает восстановление их в неискаженной форме. От успешности ее решения во многом зависит качество получаемых потоков. Традиционные методы фильтрации не всегда обеспечивают желаемый результат в условиях высокой неопределенности событий [1-3]. Не в полной мере учитывается предыстория, изменение законов проявления событий, связи обрабатываемых сигналов. Большие надежды на повышение эффективности обработки потоков кадров связывают с применением нейросетевых решений [4-6]. В интересах этого могут использоваться как рекуррентные, так и нейронные сети прямого распространения. Среди сетей прямого распространения для обработки потоков кадров нашли широкое применение двухмерные и трехмерные сверточные нейронные сети [4, 7-11]. Эти сети после глубокого обучения позволя- ют успешно распознавать наблюдаемые объекты и динамические сцены. В ряде случаев путем обратных преобразований свернутых изображений удается воспроизводить также сворачиваемые кадры. Однако этим сетям не свойственно ассоциативное запоминание обрабатываемых сигналов и извлечение ими из памяти связанных сигналов. $K$ рекуррентным нейронным сетям (РНС), применяемым для обработки потоков кадров, относятся: многослойный персептрон RMLP (Recurrent MultiLayer Perceptron), сеть Эльмана, сеть реального времени RTRN (Real Time Recurrent Network), сеть долгой краткосрочной памяти LSTM (Long Short-Term Memory), ассоциативные запоминающие устройства Хопфилда, Коско и др. [4]. Часть из них ориентирована на быструю, неглубокую обработку сигналов. Ассоциативные запоминающие устройства Хопфилда и Коско [12-17] позволяют осуществлять более глубокую обработку сигналов, но во многом не удовлетворяют требованиям реального времени. Сеть LSTM [18-20] хотя и обеспечи- 
вает долгую краткосрочную память, но лишь для тех сигналов, на которых она обучена. Эта сеть не способна ассоциативно запоминать различные сигналы и адаптироваться под входные потоки.

Одним из перспективных решений для обработки потоков кадров может выступать применение PHC с управляемыми элементами [21-23]. На эти сети, помимо восстановления потоков искаженных кадров, могут возлагаться задачи их распознавания, ассоциативного запоминания и прогнозирования событий, управления динамическими процессами и др. В таких РНС возможна одноуровневая и многоуровневая управляемая ассоциативная обработка кадров [21]. Осуществимы не только поперечные, но и продольные свертки элементов, содержащихся в кадрах [23]. На каждом уровне представления допустима своя управляемая ассоциативная обработка свернутых динамических сигналов. Успешность решения многих задач самой ассоциативной обработки сигналов на различных уровнях представления во многом зависит от возможностей РНС по восстановлению искаженных кадров. Однако потенциальные возможности РНС с управляемыми элементами по решению этой задачи остаются во многом не исследованными. Они лишь частично затронуты в работах [21, 22]. Для раскрытия потенциала этих РНС предусматривается уточнить их особенности и разработать метод оценки возможностей, получить и проанализировать результаты по восстановлению ими потоков искаженных кадров, сформулировать рекомендации по совершенствованию этих сетей.

\section{Особенности РНС с управляемыми элементами}

В соответствии со схемой РНС с управляемыми элементам (рис. 1) на ее вход подаются сигналы, предварительно разложенные на пространственно-частотные составляющие. При этом каждая составляющая преобразована в последовательность единичных импульсов (образов). Частота и фаза следования образов являются функциями от амплитуды и фазы составляющей. Рассматривая этот процесс в дискретном времени, можно считать, что на вход сети подаются кадры единичных образов - последовательности совокупностей единичных образов (CEO), несущие всю информацию о входных сигналах.

На выходе сети обработанные последовательности СЕО могут преобразовываться в соответствующие им исходные сигналы. В этой $\mathrm{PHC}$ каждый нейрон одного слоя в общем случае связан со всеми нейронами другого слоя. Связи между нейронами одного и того же слоя отсутствуют. Нейроны могут находиться в трех состояниях: ожидание, возбуждение и невосприимчивость (рефрактерность) после

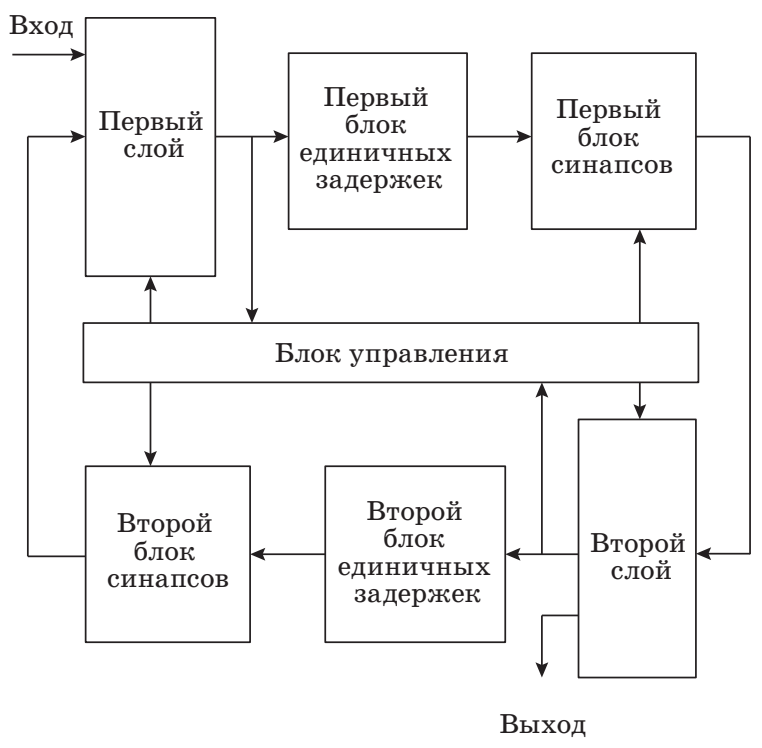

- Puc. 1. Схема рекуррентной нейронной сети с управляемыми элементами

- Fig. 1. Scheme of recurrent neural network with controlled elements

возбуждения. Время задержки импульсов (образов) в образуемых двухслойных контурах меньше времени рефрактерности нейронов. При возбуждении каждого нейрона сгенерированный импульс после единичной задержки подается на синапсы, связывающие его с другими нейронами. Каждый импульс при прохождении через синапс снимает с него информацию о предыдущих воздействиях и оставляет след о своем появлении. Веса (проводимости) синапсов определяются как [21]

$$
w_{i j}(t)=k_{i j}(t) \cdot \beta_{i j}\left(r_{i j}(t)\right) \cdot \eta_{i j}\left(r_{i j}(t)\right),
$$

где $k_{i j}(t)$ - весовой коэффициент синапса, связывающего $i$-й нейрон одного слоя с $j$-м нейроном другого слоя (размерность этого коэффициента $1 / \Omega$, значения весовых коэффициентов зависят от результатов взаимодействия нейронов); $\beta_{i j}\left(r_{i j}(t)\right), \eta_{i j}\left(r_{i j}(t)\right)$ - безразмерные функции ослабления расходящихся и сходящихся единичных образов соответственно; $r_{i j}(t)-$ расстояние между взаимодействующими нейронами, в общем случае зависящее от времени.

Заряд, переносимый от возбужденного $i$-го нейрона на вход принимающего $j$-го нейрона за время $\tau$ :

$$
q_{i j}(\tau)=\int_{0}^{\tau} u_{i}(t) \cdot\left(1-u_{j}(t) / u_{i}(t)\right) \cdot w_{i j}(t) \mathrm{d} t,
$$

где $u_{i}(t)$ - потенциал на выходе $i$-го возбужденного нейрона; $u_{j}(t)-$ потенциал на входе $j$-го принимающего нейрона. Каждый $j$-й нейрон перехо- 
дит в состояние возбуждения, если суммарный заряд $Q_{\Sigma j}(\tau)$, накапливаемый на его входе, равен или превышает порог $Q_{0}$ возбуждения:

$$
\boldsymbol{Q}_{\Sigma j}(\tau)=\sum_{i}^{N} q_{i j}(\tau) \geq \boldsymbol{Q}_{0},
$$

где $N$ - число нейронов в передающем слое.

За счет реализации в РНС пространственных сдвигов сигналов при передаче их от слоя к слою сети могут наделяться линейными, спиральными, петлевыми и другими логическими структурами [21]. Посредством сдвигов обрабатываемые в РНC CEO продвигаются вдоль слоев к выходу по предусмотренной схеме, ассоциируются друг с другом, запоминаются на элементах сети и вызывают связанные с ними сигналы. При этом недостающие сигналы могут восстанавливаться, а ложные сигналы за счет тормозящих воздействий - подавляться. Простой пример структуры РНС со спиральной схемой продвижения СЕО вдоль слоев приведен на рис. 2 .

При многоуровневой обработке сигналов в РНС с управляемыми элементами их слои могут наделяться структурами в виде нескольких взаимосвязанных сигнальных систем [21]. Кроме этого, логические поля слоев сети могут разделяться на подполя с различными характеристиками нейронов и связей между ними.

Ставится задача определить без потери общности возможности одноуровневых РНС с управ-

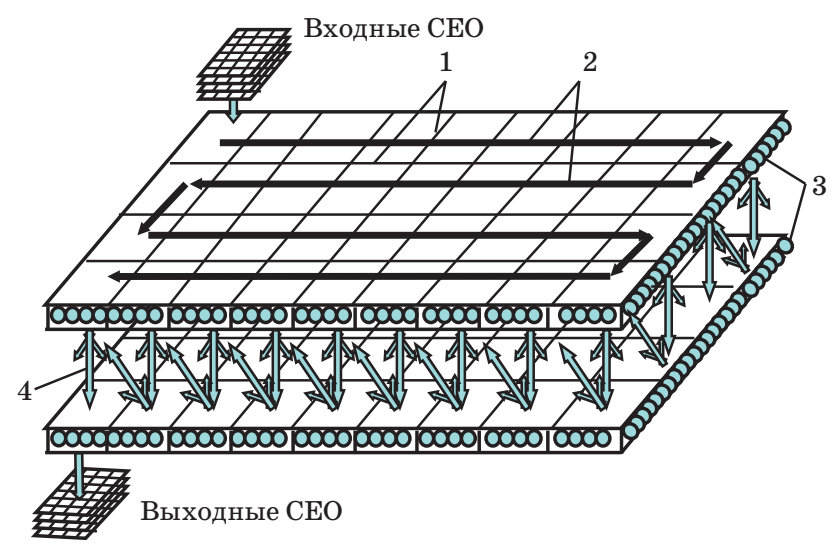

Puc. 2. Структура РНС со спиральной схемой продвижения совокупностей единичных образов вдоль слоев: 1 - линии разбивки слоев на логические поля за счет пространственных сдвигов СЕО при передаче от слоя к слою; 2 - направления продвижения СЕО вдоль слоев; 3 - нейроны; 4 - направления передачи СЕО между слоями

- Fig. 2. Structure of RNN with spiral advancement scheme of the single images sets (SSI) of along the network layers: 1 - the lines of splitting the layers into logical fields due to spatial shifts of the SSI during transmission from layer to layer; 2 - direction of SSI advancement along the layers; 3 - neurons; 4 - directions of SSI transmission between the layers ляемыми элементами по восстановлению обрабатываемых потоков кадров в зависимости от вида и размера логических структур этих сетей, а также от их циклов обучения, порогов возбуждения нейронов и масштабов расстояний между ними.

\section{Метод оценивания возможностей РНС}

Для решения этой задачи необходимо наличие обучающей последовательности эталонных кадров и последовательности искаженных совокупностей единичных образов, содержащих пропуски и ложные элементы. Реализация $L$ циклов обучения предусматривает обработку сетью $L$ одинаковых последовательностей эталонных кадров. Как обучение, так и оценку конкретных возможностей сети по восстановлению потоков искаженных кадров предлагается осуществлять на множестве допустимых вариантов порогов возбуждения нейронов и масштабов расстояний между ними.

С учетом этого предлагаемый метод оценивания возможностей РНС по восстановлению искаженных потоков кадров можно свести к следующей совокупности правил.

Шаг 1. Задание:

- исходного числа циклов обучения, $L=1$;

- минимального значения порога Thr возбуждения нейронов и величины $\Delta$ его приращения, $T h r=T h r_{0}$;

- минимального значения величины масштаба $\alpha$ расстояний между нейронами и величины $d$ его приращения, $\alpha=\alpha_{0}$;

- исходного числа успешных вариантов восстановления искаженной последовательности кадров, $W(L)=0$.

Шаг 2. Проведение $L$ циклов обучения $\mathrm{PHC}$ с заданными значениями параметров $T h r$ и $\alpha$. Обработка РНС последовательности искаженных кадров. Проверка успешности восстановления искаженной последовательности, определение значения булевой функции $\delta$. При успешном восстановлении, когда $\delta=1, W(L)=W(L)+1$.

Шаг 3. $\alpha=\alpha+d$. Если $\alpha<\alpha_{\max }+d$, то переход к шагу 2.

Шаг 4. $\alpha=\alpha_{0} . T h r=T h r+\Delta$. Если $T h r<$ $<T h r_{\max }+\Delta$, то переход к шагу 2 .

Шаг 5. $T h r=T h r_{0} . L=L+1 . W(L)=0$. Если $L<$ $<L_{\max }+1$, то переход к шагу 2.

Шаг 6. Построение графика зависимости $W(L)$.

Реализация этих правил позволяет определять число успешных вариантов восстановления искаженной последовательности кадров при $L$ циклах обучения PHC:

$$
W(L)=\sum_{z=1}^{Z} \sum_{k=1}^{K} \delta_{z k}\left(T h r_{z}, \alpha_{k}, L\right),
$$


где $\delta_{z k}\left(T h r_{z}, \alpha_{k}, L\right)$ - булева функция успешного восстановления последовательности искаженных кадров; $Z=\left(T h r_{\max }-T h r_{0}\right) / \Delta ; K=\left(\alpha_{\max }-\right.$ $\left.-\alpha_{0}\right) / d$. Заметим, что значение $\delta_{z k}\left(T h r_{z}, \alpha_{k}, L\right)$ определяется путем проведения испытаний на конкретной модели рекуррентной нейронной сети для различных сочетаний значений $\alpha$ и $T h r$. В результате таких испытаний для каждого значения $L$ формируется своя диаграмма $\delta_{z k}\left(T h r_{z}\right.$, $\left.\alpha_{k}, L\right)$ в зависимости от значений $\alpha$ и Thr. Пример такой диаграммы приведен на рис. 3.

При большом числе вариантов значений $\alpha$, $T h r$ и $L$ задача построения графика зависимости $W(L)$ с использованием полного перебора вариантов обладает высокой вычислительной сложностью. Однако есть возможность существенно снизить сложность этой задачи, если отсекать заранее неперспективные варианты. В частности, отсечение этих вариантов осуществимо путем введения в рассмотренную выше систему правил дополнительных условий. Если на предыдущем шаге поиска $\delta=1$, а на текущем шаге при $\alpha=\alpha+d$ величина $\delta$ равна нулю, то нет необходимости исследовать и другие варианты для $\alpha$ при фиксированных значениях $T h r$ и $L$. Когда на очередном шаге при фиксированном $\alpha$ и изменяемом $T h r$ величина $\delta=1$, а на следующем шаге для $T h r=T h r+\Delta$ величина $\delta=0$, то все последующие варианты для $\alpha=$ const и увеличивающегося $T h r$ бесперспективны.

Помимо этих дополнительных условий, возможны и другие правила, позволяющие снизить сложность решаемой задачи.

\section{Результаты моделирования}

C использованием предложенного метода определения возможностей РНС с управляемыми элементами по восстановлению искаженных последовательностей кадров проводилось имитационное моделирование. Исследовались возможности РНС с линейными и спиральными структурами слоев. Характеристики исследованных РНС приведены в таблице, где приняты обозначения: У - униполярная; Б - биполярная. В качестве обучающей последовательности кадров выступала последовательность, состоящая из четырех сдвинутых по времени совокупностей единичных образов, составляющих слово «С Е Т b».

Введение кадров в РНС осуществлялось на каждом четвертом шаге работы сети, так что после поступления последнего кадра обучающей последовательности в РНС с линейной структурой состояние первого слоя представлялось в виде рис. 4. Возбужденные нейроны отражены за-

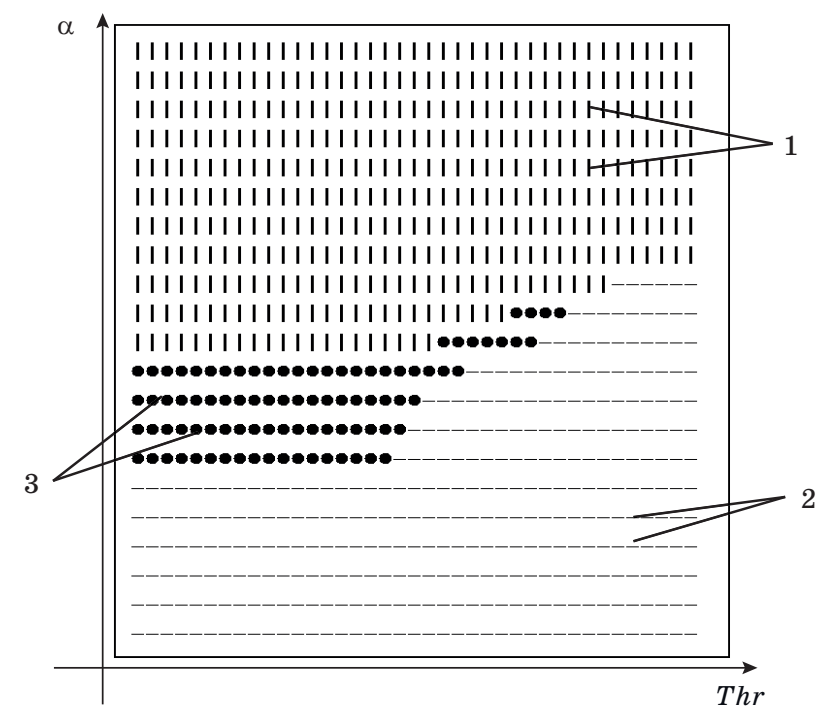

Puc. 3. Диаграмма успешных вариантов восстановления РНС искаженной последовательности кадров: 1 - варианты с ложными элементами; 2 - варианты, содержащие пропуски единичных элементов; 3 - варианты успешного восстановления последовательностей кадров

- Fig. 3. The diagram of sessions with successful restoring of distorted frame sequence: 1 - sessions with superfluous resulting elements; 2 - sessions with missing resulting elements; 3 - sessions with successful restoring of distorted frame sequence
Характеристики исследованных рекуррентных нейронных сетей с управляемыми элементами

- Characteristics of investigated recurrent neural networks with controlled elements

\begin{tabular}{|c|c|c|c|c|c|}
\hline $\begin{array}{c}\text { Вид } \\
\text { структуры } \\
\text { РНС }\end{array}$ & 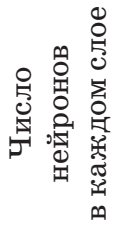 & 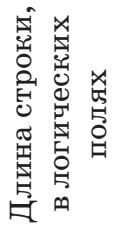 & 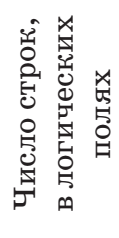 & 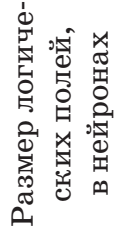 & 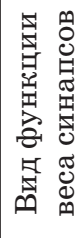 \\
\hline \multirow{2}{*}{ Линейная } & 240 & 8 & 1 & 30 & $\mathrm{y}$ \\
\hline & 480 & 16 & 1 & 30 & $\mathrm{y}$ \\
\hline \multirow{6}{*}{$\begin{array}{c}\text { Спиральная } \\
\text { полувитко- } \\
\text { вая }\end{array}$} & 240 & 4 & 2 & 30 & $\mathrm{Y}$ \\
\hline & 360 & 6 & 2 & 30 & $\mathrm{y}$ \\
\hline & \multirow{2}{*}{480} & \multirow{2}{*}{8} & \multirow{2}{*}{2} & \multirow{2}{*}{30} & $\mathrm{y}$ \\
\hline & & & & & Б \\
\hline & 540 & 9 & 2 & 30 & $\mathrm{y}$ \\
\hline & 600 & 10 & 2 & 30 & $\mathrm{Y}$ \\
\hline $\begin{array}{c}\text { Спиральная } \\
\text { одновитко- } \\
\text { вая }\end{array}$ & 720 & 8 & 3 & 30 & $\mathrm{y}$ \\
\hline $\begin{array}{c}\text { Спиральная } \\
\text { полутора- } \\
\text { витковая }\end{array}$ & 960 & 8 & 4 & 30 & y \\
\hline
\end{tabular}




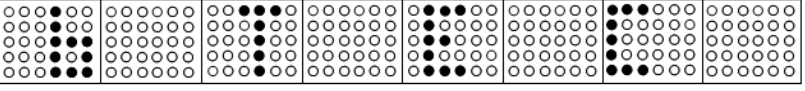

Puc. 4. Состояния первого слоя РНС с линейной структурой после введения в сеть обучающей последовательности

- Fig 4. The state of the first layer of RNN with linear structure after entering the learning sequence

темненными элементами. Искаженные кадры, вводимые в РНС, отличались от эталонных наличием в них ложных элементов и частичным отсутствием истинных единичных образов.

Сравнение возможностей РНС со спиральной полувитковой и линейной структурами (рис. 5) по восстановлению последовательностей искаженных кадров показало существенные преимущества первой.

Согласно рис. 5, кривая 1 зависимости $W(L)$ успешных вариантов восстановления искаженной последовательности РНС со спиральной полувитковой структурой слоев проходит существенно выше кривой 2 для РНС с линейной структурой. Снижение показателя $W(L)$, после его роста, c увеличением циклов обучения обусловлено несбалансированностью эффектов активации и торможения нейронов в сети при использовании униполярных функций весов синапсов. При такой несбалансированности после восстановления отсутствующих единичных элементов в обрабатываемых кадрах с ростом числа циклов обучения увеличиваются ассоциативные вызовы более слабых связанных сигналов.

Установлено, что с увеличением числа витков в структуре слоев РНС возможности восстановления искаженных последовательностей кадров

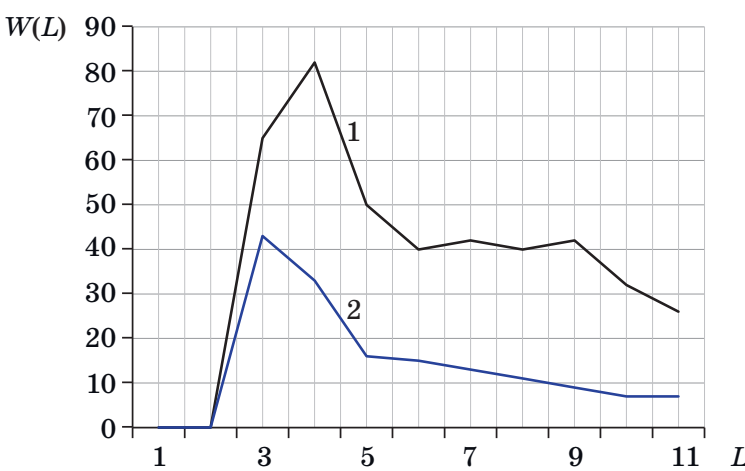

- Puc. 5. Возможности РНС с линейной и спиральной структурами слоев по восстановлению искаженных потоков кадров: 1 - для спиральной полувитковой структуры; 2 - для линейной структуры

- Fig. 5. The capabilities of RNNs with linear and spiral structures in restoring of distorted frame sequence: 1 - for the spiral half coil structure; 2 - for the linear structure растут (рис. 6). Увеличение же длины линейных структур РНС такого эффекта практически не дает.

Результаты моделирования показали также, что использование в качестве $w_{i j}$ биполярной «Б» функции веса синапсов (см. таблицу) позволяет получить выигрыш над униполярным «У» вариантом $w_{i j}$ (рис. 7).

Кроме этого, исследовались возможности восстановления потоков кадров при наличии только ложных единичных образов и только ошибок в виде отсутствия части полезных образов. Результаты такого восстановления показали (рис. 8), что, ориентируясь на раздельное устранение различных видов ошибок, даже при униполярной функции весов синапсов можно существенно повысить эффективность обработки искаженных последовательностей кадров. В данном случае число успешных вариантов восстанов-

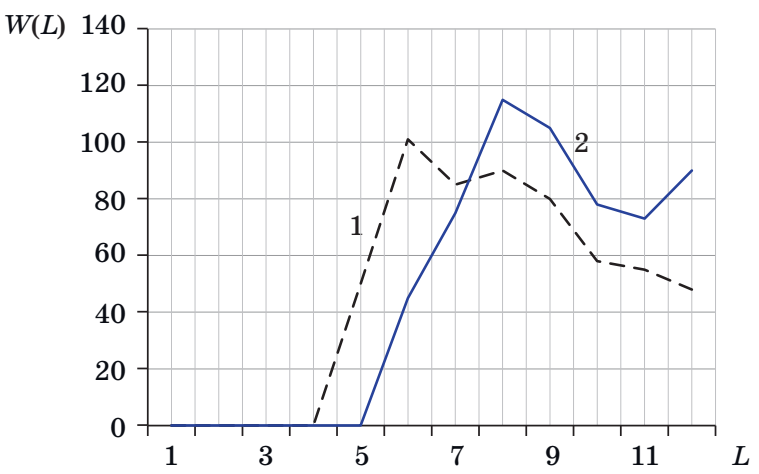

- Puc. 6. Возможности РНС со спиральными структурами слоев: 1 - для одновитковой структуры; 2 для сети с полуторавитковой структурой

- Fig. 6. The capabilities of RNNs with spiral layer structures: 1 - for the single coil structure; 2 - oneand-half coil structure

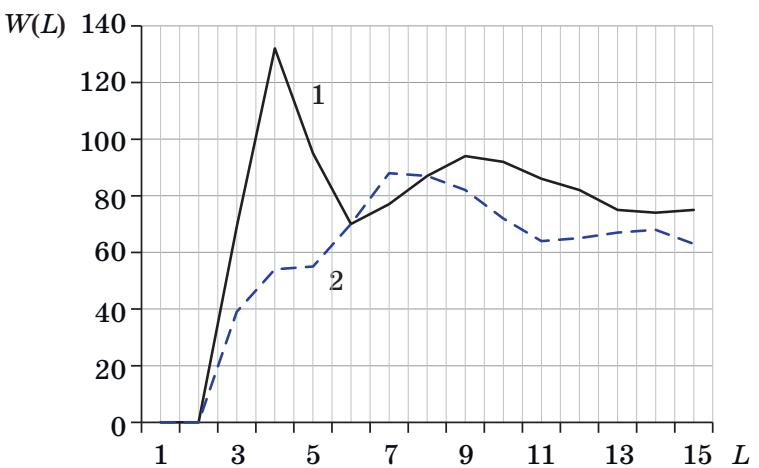

- Puc. 7. Зависимости $W(L)$ для РНС с полувитковыми структурами слоев при биполярной и униполярной функциях весов синапсов: 1 - биполярная; 2 - униполярная

- Fig. 7. Dependences $W(L)$ for RNNs with half coil structures of layers with bipolar and unipolar functions of synaptic weights: 1 - bipolar; 2 - unipolar 


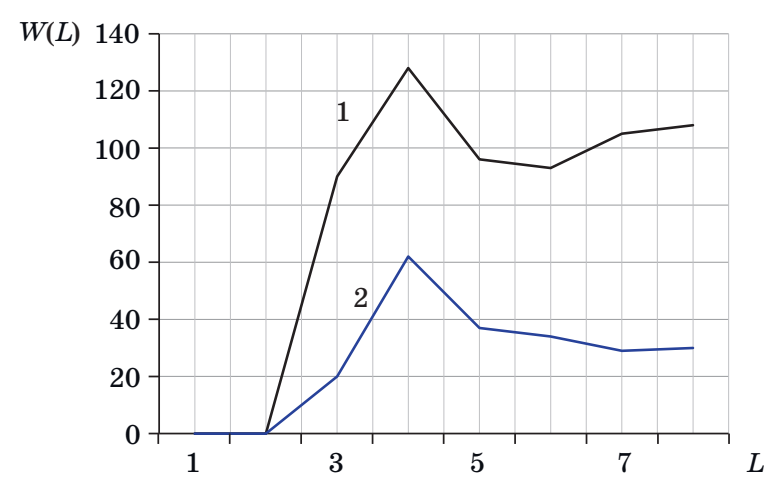

- Puc. 8. Результаты раздельного устранения различных видов ошибок в потоках кадров: 1 - устранение пропусков единичных элементов; $2-$ устранение ложных элементов

- Fig. 8. Results of separate elimination of various types of errors in frame flows: 1 - elimination of the single elements misses; 2 - elimination of false elements

ления искаженной последовательности потенциально может быть равным сумме полученных раздельных результатов. Раздельное устранение различных видов ошибок позволяет ликвидировать существующее противоречие, свойственное нейросетевой обработке сигналов. Согласно ему ошибки в виде ложных сигналов легко устраняются при высоких порогах возбуждения нейронов. Однако дефекты в виде пропусков сигналов успешно исправляются при низких порогах. При понижении этих порогов усиливаются возможности ассоциативного вызова из памяти сети запомненных сигналов, связанных с вызывающими воздействиями. Заметим, что в рассматриваемом случае РНС может функционировать более устойчиво, обеспечивая с увеличением числа циклов обучения и порога возбуждения нейронов некоторое стабильное значение $W(L)$.

Для реализации такого раздельного устранения возможных ошибок и повышения эффективности восстановления РНС потоков искаженных кадров рекомендуется управлять порогами возбуждения нейронов сети. Вначале, за счет по-

\section{Литература}

1. Davies E. R. Computer Vision: Principles, Algorithms, Applications, Learning. Fifth Ed. Academic Press, 2017. $900 \mathrm{p}$.

2. Wei X., Yang Q., Cong Y. Joint contour filtering. Journal of Computer Vision, 2018, no. 126, pp. 12451265. doi:10.1007/s11263-018-1091-5

3. Zhang Z., Xu Y., Yang J., Li X., \& Zhang D. A survey of sparse representation: algorithms and applications. IEEE Access, 2015, no. 3, pp. 490-530. doi:10.1109/ACCESS.2015.2430359 вышенных порогов, можно устранять ложные сигналы, а затем восстанавливать пропущенные элементы, ограничиваясь предельно допустимыми минимальными значениями порогов возбуждения нейронов и уровнем загрузки сети.

\section{Заключение}

Оценка возможностей рекуррентных нейронных сетей с управляемыми элементами по восстановлению потоков искаженных кадров показала высокую их зависимость от вида структуры этих сетей и параметров настройки. В лучшую сторону отличаются РНС со спиральными структурами слоев. При этом с увеличением числа витков спирали растут и возможности РНС. Повышение возможностей РНС по восстановлению потоков искаженных кадров осуществимо при переходе от униполярных к биполярным функциям весов синапсов нейронов. Кроме этого, существенное увеличение возможностей исследуемых РНС возможно за счет управления порогами возбуждения нейронов для реализации последовательного, а не параллельного устранения различных видов ошибок. В отличие от известных нейронных сетей рекуррентные нейронные сети с управляемыми элементами позволяют адаптироваться к изменениям законов, свойственных потокам кадров, реализовывать управляемую ассоциативную обработку сигналов. Проведенные эксперименты показали, что эти РНС могут учитывать за счет ассоциативных связей глубокий текущий опыт обработки сигналов и успешно применяться для восстановления потоков искаженных кадров. Для выполнения имитационного моделирования больших и сверхбольших РНС с управляемыми элементами в настоящее время можно использовать серверы с графическими процессорами. Для малогабаритного и эффективного в части потребляемой энергии исполнения сверхбольших $\mathrm{PHC}$ применимы современные мемристивные технологии.

4. Haykin S. Neural Networks and Learning Machines. Third Ed. New-York, Prentice Hall, 2008. 938 p.

5. Zennaro F. M., Chen K. Towards understanding sparse filtering. A theoretical perspective. Neural Networks, 2018, no. 98, pp. 154-177. doi:10.1016/j.neunet.2017.11.010

6. Bruce N. D., Rahman S., \& Carrier D. Sparse coding in early visual representation: from specific properties to general principles. Neurocomputing, 2016, no. 171, pp. 1085-1098. doi:10.1016/j.neucom.2015.07.070

7. Wang Y., Luo B., Shen J., Pantic M. Face mask extraction in video sequence. International Journal of 
Computer Vision, 2018, Nov, pp. 1-17. doi:10.1007/ s11263-018-1130-2

8. Wang H., Shen Y., Wang S., Xiao T., Deng L., Wang X., Zhao X. Ensemble of 3D densely connected convolutional network for diagnosis of mild cognitive impairment and Alzheimer's disease. Neurocomputing, 2019, no. 333, pp. 145-156. doi:10.1016/j.neucom. 2018.12.018

9. Wang R. Edge detection using convolutional neural network. Advances in neural networks: Proc. of the 13th International Symposium on Neural Networks, ISNN 2016, Saint-Petersburg, Russia, July 6-8, 2016, LNCS, 2016, no. 9719, pp. 12-20. doi:10.1007/ 978-3-319-40663-3_2

10. Vasamsetti S., Mittal N., Neelapu B. C., Sardana H. K. 3D local spatio-temporal ternary patterns for moving object detection in complex scenes. Cognitive Computation, 2019, no. 11, pp. 18-30. doi:10.1007/s12559018-9594-5

11. Badrinarayanan V., Kendall A., \& Cipolla R. Segnet: A deep convolutional encoder-decoder architecture for image segmentation. IEEE Transactions on Pattern Analysis and Machine Intelligence, 2017, no. 39(12), pp. 2481-2495. doi:10.1109/TPAMI.2016. 2644615

12. Hopfield J. J. Neural networks and physical systems with emergent collective computational abilities. Proc. of the National Academy of Science, USA, 1982, no. 79 , pp. 2554-2558.

13. Kosco B. Bidirectional associative memories. IEEE Transactions on Systems, Man, and Cybernetics, 1988, no. 18(1), pp. 49-60.

14. Liu J., Gong M., He H. Deep associative neural network for associative memory based on unsupervised representation learning. Neural Networks, 2019, no. 113, pp. 41-53. doi:10.1016/j.neunet.2019.01.004

15. Erick Cabrera E., Sossa H. Generating exponentially stable states for a Hopfield neural network. Neuro- computing, 2018, no. 275, pp. 358-365. doi:10.1016/j. neucom.2017.08.032

16. Sha C., Zhao H. Design and analysis of associative memories based on external inputs of continuous bidirectional associative networks. Neurocomputing, 2017, no. 266, pp. 433-444. doi:10.1016/j.neucom. 2017.05.056

17. Mizraji E., Lin J. Modeling spatial-temporal operations with context-dependent associative memories. Cognitive Neurodynamics, 2015, vol. 9, iss. 5, pp. 523534. doi:10.1007/s11571-015-9343-3

18. Yang B., Sun S., Li J., Lin X., Tian Y. Traffic flow prediction using LSTM with feature enhancement. Neurocomputing, 2019, no. 332, pp. 320-327. doi:10.1016/j.neucom.2018.12.016

19. Yu Z., Liu G., Liu Q., Deng J. Spatio-temporal convolutional features with nested LSTM for facial expression recognition. Neurocomputing, 2018, no. 317, pp. 50-57. doi:10.1016/j.neucom.2018.07.028

20. Liu G., Guo J. Bidirectional LSTM with attention mechanism and convolutional layer for text classification. Neurocomputing, 2019, no. 337, pp. 325-338. doi:10.1016/j.neucom.2019.01.078

21. Osipov V., Osipova M. Space-time signal binding in recurrent neural networks with controlled elements. Neurocomputing, 2018, no. 308, pp. 194-204. doi:10. 1016/j.neucom.2018.05.009

22. Osipov V., Nikiforov V. Functional and structural features of recurrent neural networks with controlled elements. Advances in Neural Networks - ISNN 2019: Proceedings of the 16th International Symposium on Neural Networks, ISNN 2019, Moscow, Russia, July 10-12, 2019, Part I, Springer, 2019, pp. 133-140.

23. Osipov V. Structure and basic functions of cognitive neural network machine. MATEC Web of Conferences, 2017, no. 02011, p. 113. doi:10.1051/matecconf/ 201711302011

\section{UDC 004.8}

doi:10.31799/1684-8853-2019-5-10-17

\section{Recurrent neural networks with controlled elements in restoring frame flows}

V. Yu. Osipova ${ }^{a}$, Dr. Sc., Tech., Professor, orcid.org/0000-0001-5905-4415, osipov_vasiliy@mail.ru

V. V. Nikiforov ${ }^{a}$, Dr. Sc., Tech., Professor, orcid.org/0000-0002-6836-6303

aSaint-Petersburg Institute for Informatics and Automation of the RAS, 39, 14 Line, V. O., 199178, Saint-Petersburg, Russian Federation

Introduction: Various interfering influences raise pressing problems of promptly restoring the flow of distorted frames, remembering about the background and dynamics of the event measurement laws. The traditional methods of recovering flows of distorted frames do not fully take into account the peculiarities of this process. Purpose: Exploring the possibilities of recurrent neural networks with controlled elements for restoring frame flows. Results: It is proposed to evaluate the potential of a recurrent neural network with controlled elements by the number of successful options for restoring a distorted sequence of frames. Evaluation of the capabilities of such neural networks according to the introduced indicator showed their strong dependence on the type of network structure and settings. Recurrent neural networks with spiral structures of layers work better. As the number of the turns in the helix grows, the network capabilities also grow. Enhancing the capacity of a network to restore distorted frame flows is feasible if we replace unipolar functions of the synapse weights by bipolar ones. A significant increase in the capabilities of the neural networks under study is possible by controlling the neuron excitation thresholds in order to provide sequential rather than parallel elimination of various errors. In contrast to the conventional neural networks, recurrent neural networks with controlled elements can adapt to changes in 
the laws inherent in frame flows, and implement controlled associative signal processing. Experiments have shown that these neural networks can use associative connections for taking into account deep current experience in signal processing, and be successfully used for restoring distorted frame flows.

Keywords - distorted frame flow, recovery, recurrent neural network, logical structure, control, evaluation.

For citation: Osipov V. Yu., Nikiforov V. V. Recurrent neural networks with controlled elements in restoring frame flows. Informatsionnoupravliaiushchie sistemy [Information and Control Systems], 2019, no. 5, pp. 10-17 (In Russian). doi:10.31799/1684-8853-2019-5-10-17

\section{References}

1. Davies E. R. Computer Vision: Principles, Algorithms, Appli cations, Learning. Fifth Ed. Academic Press, 2017. 900 p.

2. Wei X., Yang Q., Cong Y. Joint Contour Filtering. Journal of Computer Vision, 2018, no. 126, pp. 1245-1265. doi:10. 1007/s11263-018-1091-5

3. Zhang Z., Xu Y., Yang J., Li X., \& Zhang D. A survey of sparse representation: algorithms and applications. Access, $I E E E$, 2015, no. 3, pp. 490-530. doi:10.1109/ACCESS. 2015.2430359

4. Haykin S. Neural Networks and Learning Machines. Third Ed. New-York, Prentice Hall, 2008. 938 p.

5. Zennaro F. M., Chen K. Towards understanding sparse filtering. A theoretical perspective. Neural Networks, 2018, no. 98, pp. 154-177. doi:10.1016/j.neunet.2017.11.010

6. Bruce N. D., Rahman S., \& Carrier D. Sparse coding in early visual representation: from specific properties to general principles. Neurocomputing, 2016, no. 171, pp. 1085-1098. doi:10.1016/j.neucom.2015.07.070

7. Wang Y., Luo B., Shen J., Pantic M. Face mask extraction in video sequence. International Journal of Computer Vision, 2018, Nov, pp. 1-17. doi:10.1007/s11263-018-1130-2

8. Wang H., Shen Y., Wang S., Xiao T., Deng L., Wang X. Zhao X. Ensemble of 3D densely connected convolutional network for diagnosis of mild cognitive impairment and Alzheimer's disease. Neurocomputing, 2019, no. 333, pp. 145-156. doi:10.1016/j.neucom.2018.12.018

9. Wang R. Edge detection using convolutional neural network. Advances in neural networks: Proc. of the 13th International Symposium on Neural Networks, ISNN 2016, Saint-Petersburg, Russia, July 6-8, 2016, LNCS, 2016, no. 9719, pp. 12-20. doi:10.1007/978-3-319-40663-3 2

10. Vasamsetti S., Mittal N., Neelapu B. C., Sardana H. K. 3D local spatio-temporal ternary patterns for moving object detection in complex scenes. Cognitive Computation, 2019, no. 11, pp. 18-30. doi:10.1007/s12559-018-9594-5

11. Badrinarayanan V., Kendall A., \& Cipolla R. Segnet: A deep convolutional encoder-decoder architecture for image segmentation. IEEE Transactions on Pattern Analysis and Ma chine Intelligence, 2017, no. 39(12), pp. 2481-2495. doi:10.1109/TPAMI.2016.2644615

12. Hopfield J. J. Neural networks and physical systems with emergent collective computational abilities. Proc. of the $\mathrm{Na}$ tional Academy of Science, USA, 1982, no. 79, pp. 25542558.
13. Kosco B. Bidirectional associative memories. IEEE Trans actions on Systems, Man, and Cybernetics, 1988, no. 18(1), pp. 49-60.

14. Liu J., Gong M., He H. Deep associative neural network for associative memory based on unsupervised representation learning. Neural Networks, 2019, no. 113, pp. 41-53. doi:10. 1016/j.neunet.2019.01.004

15. Erick Cabrera E., Sossa H. Generating exponentially stable states for a Hopfield neural network. Neurocomputing, 2018 , no. 275 , pp. 358-365. doi:10.1016/j.neucom. 2017.08.032

16. Sha C., Zhao H. Design and analysis of associative memories based on external inputs of continuous bidirectional associative networks. Neurocomputing, 2017, no. 266, pp. 433-444. doi:10.1016/j.neucom.2017.05.056

17. Mizraji E., Lin J. Modeling spatial-temporal operations with context-dependent associative memories. Cognitive Neurodynamics, 2015, vol. 9, iss. 5, pp. 523-534. doi:10. 1007/s11571-015-9343-3

18. Yang B., Sun S., Li J., Lin X., Tian Y. Traffic flow prediction using LSTM with feature enhancement. Neurocomput ing, 2019, no. 332, pp. 320-327. doi:10.1016/j.neucom. 2018.12.016

19. Yu Z., Liu G., Liu Q., Deng J. Spatio-temporal convolutional features with nested LSTM for facial expression recognition. Neurocomputing, 2018, no. 317, pp. 50-57. doi:10.1016/ j.neucom.2018.07.028

20. Liu G., Guo J. Bidirectional LSTM with attention mechanism and convolutional layer for text classification. Neurocomputing, 2019, no. 337, pp. 325-338. doi:10.1016/j.neucom.2019.01.078

21. Osipov V., Osipova M. Space-time signal binding in recurrent neural networks with controlled elements. Neurocomputing, 2018, no. 308, pp. 194-204. doi:10.1016/j.neucom. 2018.05.009

22. Osipov V., Nikiforov V. Functional and structural features of recurrent neural networks with controlled elements. Proceedings of the 16th International Symposium on Neural Networks "Advances in Neural Networks - ISNN 2019", Moscow, Russia, July 10-12, 2019, Part I, Springer, 2019, pp. $133-140$.

23. Osipov V. Structure and basic functions of cognitive neural network machine. MATEC Web of Conferences, 2017, no. 02011, p. 113. doi:10.1051/matecconf $/ 201711302011$ 


\title{
Models of forecasting destructive influence risks for information processes in management systems
}

\author{
V. G. Anisimova, Dr. Sc., Tech., Professor, orcid.org/ 0000-0002-5097-4618, an-33@yandex.ru \\ E. G. Anisimov'b, Dr. Sc., Tech., Professor orcid.org/ 0000-0002-6527-2352 \\ T. N. Saurenkob', Dr. Sc., Econ., Head of Chair, orcid.org/ 0000-0003-1736-7178 \\ E. A. Zotova ${ }^{a}$, Assistant Professor, orcid.org/ 0000-0003-4539-4253 \\ aPeter the Great St. Petersburg Polytechnic University, 29, Politekhnicheskaia St., 195251, Saint-Petersburg, \\ Russian Federation \\ bPeoples' Friendship University of Russia (RUDN University), 6, Miklukho-Maklay St., 117198, Moscow, \\ Russian Federation
}

\begin{abstract}
Introduction: One of the side effects of introducing modern information technologies in the management of economic, social, organizational and technical systems is the stronger dependence of the management quality on intentional or accidental destructive influences which violate the integrity, confidentiality and availability of the information used. This determines the relevance of developing appropriate information security systems. The substantiation of the development of such systems requires solving the problems of comparative assessment of the destructive impact risks and the cost of their prevention. Purpose: Predicting the danger of a destructive impact on information processes in control systems. Method: The prediction is based on representing the destructive effects in the form of a random sequence of events which lead to disruptions in the information processes. The consequences of failures are also represented by certain random variables. Results: Methodical approaches are proposed in order to build models for predicting temporal and volumetric characteristics of damage from destructive influences on information processes in the management of economic, social, organizational and technical systems. In these models, we suggest to assess the danger of destructive impacts by the probability of the onset of a destructive event at a certain time moment, and by the amount of damage caused by it. The basis for the construction of prediction models is the presentation of damage indicators in the form of step functions of time. The constructive representation of these functions is based on the conditional deterministic approach. The completeness of a priori information usage in determining specific parameters of the damage functions is ensured by applying the maximum uncertainty principle. The measure for the uncertainty is entropy. The conditional deterministic approach for higher uncertainty levels was developed in a stochastic approach. On its basis, classes of stochastic models were proposed, corresponding to various information situations. These models allow you to estimate not only the expected values of damage indicators due to the failure in taking measures to ensure information security while managing targeted systems, but also their probabilistic characteristics. Practical relevance: The proposed approaches are the basis for the creation of particular models and techniques in the interests of well substantiated decisions on the formation of the structure of the organization and management of information security subsystems.
\end{abstract}

Keywords - information systems, information security, destructive impacts, damage, damage prediction models.

For citation: Anisimov V. G., Anisimov E. G., Saurenko T. N., Zotova E. A. Models of forecasting destructive influence risks for information processes in management systems. Informatsionno-upravliaiushchie sistemy [Information and Control Systems], 2019, no. 5, pp. 18-23. doi:10.31799/1684-8853-2019-5-18-23

\section{Introduction}

The functional success of different goal-oriented systems (economic, social, organizational, technical ones) is defined by the effectiveness of their management. The extent to which the potential resources of these systems are used to achieve goals reflects the effectiveness of their management. It depends on the completeness, reliability and timeliness of information about the current state of a goal-oriented system and the external environment, as well as on the ability of control subsystems to form and realize effective control actions. Therefore, currently information technology is being widely implemented in order to manage these systems effectively.

With modern information technology introduced to the management of economic, social, or- ganizational and technical systems, the quality of management is becoming increasingly dependent on intentional and accidental destructive influences, which violate the integrity, confidentiality and availability of information used [1-6]. So appropriate information security subsystems are created. In order to justify the decisions on the composition of the organization's structure and the operation of such subsystems, the risk must be assessed concerning various destructive influences that affect information processes in the corresponding management systems. The basis of the assessment is projecting the temporal and quantitative characteristics of the damage. This paper proposes methodological approaches which can be used to build conditionally deterministic and stochastic models intended for forecasting these characteristics based on the representation of damage indicators in the 
form of jump functions of time. To ensure the most complete use of a priori information when determining the specific parameters of these functions, it is proposed to be guided by the requirements of the maximum uncertainty principle.

\section{Methodical approach to building conditionally determined models for forecasting the risk of destructive influences}

When applying the conditionally deterministic approach, the dynamics of damages from the destructive influences exerted on information processes of management systems are simulated using the following relations:

$$
x(t)=\sum_{j=1}^{n} a_{j} n\left(t-t_{j}\right),
$$

where $x(t)$ is the expected value of the selected damage indicator by time $t ; j$ is the identifier of the destructive event; $n$ is the number of possible destructive events; $a_{j}$ is the expected magnitude of the increase in the damage value associated with the destructive event; $t_{j}$ is the expected time when the destructive event occurs;

$$
n\left(t-t_{j}\right)=\left\{\begin{array}{l}
1, \text { if }\left(t-t_{j}\right)>0 \\
0, \text { if }\left(t-t_{j}\right) \leq 0
\end{array}, j=1,2, \ldots, n\right.
$$

Constructive representation of relations (1) requires the definition of the type and specific parameters of functions

$$
\begin{aligned}
& a_{j}=f_{1}(j) \\
& t_{j}=f_{2}(j) .
\end{aligned}
$$

The initial information for solving this problem is a set of data on the values of $x_{j}, t_{j}$ accumulated during the period preceding the forecast, as well as a priori data on the possible nature of the forecasted processes, obtained on the basis of expert assessments and (or) management experience of similar economic, social, organizational and technical systems [7-10].

If the principle of maximum uncertainty is applied, it ensures the completeness of the used information in determining specific parameters of the functions (3), (4). This principle postulates that the least dubious representation of these functions will be one that takes into account all given information and maximizes uncertainty [11].

Such an approach to the construction of the given functions allows us to minimize the impact of subjective assessments and at the same time take into full account the available objective information on the conditions of implementation and the characteristics of damage from the destructive influence on information processes in the management systems we study.

The experience of managing various economic, social, organizational and technical systems shows that as they develop and consolidate, the jumps in the values of damage indicators increase due to the occurrence of subsequent destructive events, that is, the following condition is true for the values of function (3)

$$
a_{n}>a_{n-1}>\ldots>a_{1} \text {. }
$$

With regard to function (4) we can assume that, if no measures are taken to ensure information security

$$
t_{1}>t_{2}>\ldots>t_{n}
$$

it is a decreasing function of the integer argument $j$.

If relations (5) and (6) are true and the values $a_{j}$ and $t_{j}$ are independent, the average jump in the damage indicator over the previous operation period of the information system equals $a_{0}$, and the average time between destructive impacts during this period is $t_{0}$, the ratio (3) can be represented as follows

$$
a_{j}=a_{0} F_{1}(j), j=1,2, \ldots, n
$$

where $F_{1}(j)$ is the corresponding probability functions for the elements in the relation (5).

Function (4) can be represented as

$$
t_{j}=t_{0} F_{2}(j), j=1,2, \ldots, n,
$$

where $F_{2}(j)$ is the corresponding probability functions for elements in the relation (6).

The implementation of the maximum uncertainty principle in the definition of functions $F_{1}(j), F_{2}(j)$ is ensured by the use of appropriate conditional optimization models $[12,13]$. At the same time, in the information situation we consider, it is appropriate to use the second-order entropy to estimate the level of uncertainty

$$
H_{2}\left(F_{2}\right)=\prod_{j=1}^{n} F_{2}^{n-j+1}(j) .
$$

Then the problem model for determining the probability function $F_{2}(j)$ included in (8) takes the following form $[12,13]$ :

$$
H_{2}\left(F_{2}\right)=\prod_{j=1}^{n} F_{2}^{n-j+1}(j) \underset{F_{2}(j)}{\rightarrow} \max ;
$$




$$
\sum_{j=1}^{n} F_{2}(j)=1
$$

Solving this problem with regard to condition (6), we obtain

$$
F_{2}(j)=\frac{n-j+2}{n \cdot 2^{j}}, j=1,2, \ldots, n .
$$

The functions $F_{1}(j)$ included in (7) are determined by the relation

$$
F_{1}(j)=1-F_{2}(j), j=1,2, \ldots, n .
$$

If the assumptions about the mandatory increase in the magnitude of jumps in damage indicators for destructive influences can be weakened, then relation (5) takes the form

$$
a_{n} \geq a_{n-1} \geq \ldots \geq a_{1} \text {. }
$$

Then the maximum entropy function of the elements probabilities for the variational series (7) has the form

$$
F_{1}(j)=1-\frac{2 n-j+1}{n(n+1)}, j=1,2, \ldots, n .
$$

If it is appropriate to weaken the assumption that the intensity of destructive influences increases, relation (6) can be represented as

$$
t_{1} \geq t_{2} \geq \ldots \geq t_{n}
$$

Then the maximum entropy function $F_{2}(j)$ is determined by the relation

$$
F_{2}(j)=1-\frac{2 n-j+1}{n(n+1)}, j=1,2, \ldots, n .
$$

Relations (12), (15), (17) were obtained for the first time in [12].

In general, relations (1)-(4), (7), (8), (12), (13) represent a class of conditionally determined forecasting models of jumps in the values of estimated damage indicators from destructive influences exerted on information processes in control systems under the assumptions about the nature of the processes given by relations (5), (6).

Relations (1)-(4), (7), (8), (15), (16) represent a class of conditionally determined forecasting models of jumps in the values of estimated damage indicators from destructive influences on information processes in control systems under the assumptions about the nature of the processes given by relations (5), (14).

Relations (1)-(4), (15), (17) represent a class of conditionally determined forecasting models of jumps in the values of estimated damage indicators under the assumptions set by the relations (14), (16)

\section{Methodical approach to building stochastic forecasting models for the risk of destructive influences}

We should note that the conditionally deterministic approach to building forecasting models does not take into account to a full extent the random nature of the results of destructive influence exerted on information processes in management systems. Therefore, along with these models, in some cases it is reasonable to use stochastic models, which allow us to estimate not only the expected values of the corresponding damage indicators, but also their probabilistic characteristics.

In order to build stochastic forecasting models of the danger of destructive influences, the set of values $x_{j}, t_{j}$, which was determined during the period preceding the forecast, should be considered as a sample

$$
x_{1}, t_{1} ; x_{2}, t_{2} ; \ldots ; x_{n}, t_{n}
$$

of random values of jumps $X$ of the estimated damage indicator and frequency $T$ of their appearance governed by the law of two-dimensional distribution $Q(x, t)$ of the population. The possibilities of building various stochastic models are determined by the size of this sample. If the sample size is sufficient to determine only average time $\bar{t}$ between destructive influences

$$
\bar{t}=\frac{\sum_{i=1}^{n} t_{i}}{n}
$$

and average damage $\bar{x}$, due to these influences

$$
\bar{x}=\frac{\sum_{i=1}^{n} x_{i}}{n} .
$$

Then in such an informational situation there are no objective grounds for assuming random variables $T$ and $X$ to be dependent, and the function of their joint distribution is determined by the relation

$$
Q(x, t)=W_{1}(x) W_{2}(t)
$$

and the density function of this distribution is determined by the ratio

$$
q(x, t)=\frac{\partial W_{1}(x) W_{2}(t)}{\partial x \partial t} .
$$


In relations (21), (22) $W_{1}(x), W_{2}(t)$ are the particular (marginal) distribution functions of the random variables $X$ and $T$, respectively. At the same time, based on the principle of "maximum uncertainty" in the information situation under consideration, the distributions $W_{1}(x)$ and $W_{2}(t)$ can be considered exponential:

$$
\begin{aligned}
& W_{1}(x)=1-e^{-\frac{1}{\bar{x}} x} ; \\
& W_{2}(t)=1-e^{-\frac{1}{\bar{t}} t} .
\end{aligned}
$$

If the sample size is sufficient to determine not only the average time $t_{0}$ between destructive influences causing damage and the average value $x_{0}$ of the jump in the damage indicator, but also the correlation coefficient $r_{x t}$ :

$$
r_{x t}=\frac{\sum_{i=1}^{n}\left(x_{i}-\bar{x}\right)\left(t_{i}-\bar{t}\right)}{\sqrt{\sum_{i=1}^{n}\left(x_{i}-\bar{x}\right)^{2}} \sqrt{\sum_{i=1}^{n}\left(t_{i}-\bar{t}\right)^{2}}},
$$

then the two-dimensional Gumbel distribution [14] is the model for the forecasting of jumps in the damage indicator in accordance with the principle of "maximum uncertainty" when measuring uncertainty using the first-order entropy.

Taking into account the previously adopted notation, the density function of this distribution is

$$
q(x, t)=\frac{1}{\bar{x} \bar{t}} \exp \left(\frac{x t}{\bar{x} \bar{t}}\right)\left[1+\rho\left(2 e^{-\frac{x}{\bar{x}}}-1\right)\left(2 e^{-\frac{t}{\bar{t}}}-1\right)\right]
$$

The parameter $\rho$ of function (18) is determined by the relation

$$
\rho=4 r_{x t}
$$

But if the sample size (18), along with the mathematical expectations $\bar{x}, \bar{t}$, the variances $\sigma_{x}^{2}, \sigma_{t}^{2}$ and the correlation coefficient $r_{x t}$ of random variables $X$ and $T$, allows determining the partial laws $W_{1}(x), W_{2}(t)$ of their distribution, then the form of the joint distribution function of the random variables under consideration can be refined. Since the available objective information about their joint distribution is only this sample, it is advisable to accept the identity of mathematical expectations, variances and correlation coefficient for the function $q(x, t)$ and the sample (18) as the criterion for the compliance of the function $q(x, t)$ of the real density function of the joint distribution of random variables $X$ and $T$. In this case, the most appropriate form of function $q(x, t)$ the presentation is the following:

$$
q(x, t)=w_{1}(x) w_{2}(t)\left\{1+\gamma\left[1-2 W_{1}(x)\right]\left[1-2 W_{2}(t)\right]\right\},
$$

where $W_{1}(x)$ is the partial density distribution function of random variable $X ; W_{2}(t)$ is the partial density distribution function of random variable $T$; $\gamma$ is the parameter of the law of joint distribution of random variables $X$ and $T$.

The density distribution function (28) is a generalization of the function (26), and parameter $\gamma$ is the linear function of the correlation coefficient:

$$
\gamma=r_{x t} J_{0}\left[W_{1}(x), W_{2}(t)\right]
$$

where $J_{0}\left[W_{1}(x), W_{2}(t)\right]$ is the functional defined by the partial laws $W_{1}(x), W_{2}(t)$ of the distribution of random variables $X$ and $T$.

The value $J_{0}\left[W_{1}(x), W_{2}(t)\right]$ is determined by the ratio:

\begin{tabular}{|c|c|c|c|c|c|c|}
\hline \multirow{2}{*}{$\begin{array}{c}\text { Partial } \\
\text { distributions }\end{array}$} & Distribution density & Distribution function & Distribution parameters & $J_{1}$ & $J_{0}\left[W_{1}(x), W_{2}(t)\right]$ \\
\cline { 4 - 5 } $\begin{array}{c}W_{1}(x)- \\
\text { exponential } \\
0<x<\infty\end{array}$ & $w_{1}(x)=\frac{1}{\bar{x}} e^{-\frac{1}{\bar{x}} x}$ & $W_{1}(x)=1-e^{-\frac{1}{\bar{x}} x}$ & $\bar{x}$ & $\bar{x}^{2}$ & $\frac{3 \bar{x}}{2}$ & \\
\hline $\begin{array}{c}W_{2}(t)- \\
\text { exponential } \\
0<t<\infty\end{array}$ & $w_{2}(t)=\frac{1}{\bar{t}} e^{-\frac{1}{\bar{t}} t}$ & $W_{2}(t)=1-e^{-\frac{1}{\bar{t}} t}$ & $\bar{t}$ & $\bar{t}^{2}$ & $\frac{3 \bar{t}}{2}$ & \\
\hline $\begin{array}{c}W_{1}(x)- \\
\begin{array}{c}\text { uniform } \\
0<x<a\end{array}\end{array}$ & $w_{1}=\frac{1}{a}$ & $W_{1}(x)=\frac{x}{a}$ & $\frac{a}{2}$ & $\frac{a^{2}}{12}$ & $\frac{2 a}{3}$ & \\
\hline $\begin{array}{c}W_{2}(t)- \\
\text { exponential } \\
0<t<\infty\end{array}$ & $w_{2}(t)=\frac{1}{\bar{t}} e^{-\frac{1}{\bar{t}} t}$ & $W_{2}(t)=1-e^{-\frac{1}{\bar{t}} t}$ & $\bar{t}$ & $\bar{t}^{2}$ & $\frac{3 \bar{t}}{2}$ & $\frac{6}{\sqrt{3}}$ \\
\hline
\end{tabular}




$$
J_{0}\left[W_{1}(x), W_{2}(t)\right]=\frac{\sigma_{x} \sigma_{t}}{\left(\bar{x}+J_{1}\right)\left(\bar{t}+J_{2}\right)},
$$

where $J_{1}=2 \int x w_{1}(x) W_{1}(x) \mathrm{d} x ; J_{2}=2 \int t w_{2}(t) W_{2}(t) \mathrm{d} t$.

The values of parameters $J_{0}, J_{1}, J_{2}$ for some typical partial laws of distribution of random variables $X$ and $T$ are given in the table.

The integral probability distribution function for the functions (22), (26), (28) is

$$
Q(x, t)=\int_{0}^{t} \int_{0}^{x} q(x, t) \mathrm{d} x \mathrm{~d} t .
$$

Using this function, it is possible to determine the probability that, if no measures are taken to ensure information security during time $t$, there will be damage of value $x$.

In general, relations (22), (26), (28), (31) represent a class of stochastic models that allow estimating not only the expected values of damage indicators due to failing to take information security measures when managing goal-oriented systems, but also their probabilistic characteristics.

\section{References}

1. Garcia-Font V., Garrigues C., Rifà-Pous H. Attack classification schema for smart city WSNs. Sensors, 2017, vol. 17, no. 4, p. 771.

2. Perera C., Ranjan R., Wang L., Khan S. U., Zomaya A. Y. Big data privacy in the internet of things era. IT Professional, 2015, vol. 17, iss. 3, pp. 32-39.

3. Anisimov V. G., Zegzhda P. D., Anisimov E. G., Bazhin D. A. A Risk-oriented approach to the control arrangement of security protection subsystems of information systems. Automatic Control and Computer Sciences, 2016, vol. 50, no. 8, pp. 717-721.

4. Samonas S., Coss D. The CIA strikes back: redefining confidentiality, integrity and availability in security. Journal of Information System Security, 2014, vol. 10 , no. 3, pp. 21-45.

5. Open Group Standard: Open Information Security Management Maturity Model (O-ISM3), Version 2.0. Reading, Berkshire, U. K., The Open Group, 2017. $130 \mathrm{p}$.

6. Anisimov V. G., Zegzhda P. D., Anisimov E. G., Saurenko T. N., Prisyazhnyuk S. P. Indices of the effectiveness of information protection in an information interaction system for controlling complex distributed organizational objects. Automatic Control and Computer Sciences, 2017, vol. 51, no. 8, pp. 824-828.

7. Bertino E., Ferrari E. Big Data Security and Privacy. In: A Comprehensive Guide Through the Italian Database Research Over the Last 25 Years. Studies in Big Data, Springer, 2018. Vol. 31. Pp. 425-439.

\section{Conclusion}

The widespread adoption of information technology in the management of economic, social, organizational and technical systems and the globalization of information systems are accompanied by the aggravating problem of coping with destructive influences that violate the integrity, confidentiality and availability of information used. Its solution involves the creation of information security subsystems within the framework of information and management systems. Generating informed decisions on their creation and operation is based on predicting the danger of destructive influences on information processes in control systems. The paper proposed methodological approaches to the construction of models of such a forecast. The specific feature of the approaches is the fact that the "maximum uncertainty" principle in the maximum entropy form is used to integrate the available information on the nature of the forecasted processes. This allows us to increase the reliability of the forecast and thereby increase the validity of decisions on the creation and development of the functioning of information security subsystems.

8. Anisimov V. G., Anisimov E. G., Saurenko T. N., Sonkin M. A. The Model and the planning method of volume and variety assessment of innovative products in an industrial enterprise. Journal of Physics: Conference Series, 2017, vol. 803, no. 1, p. 012006. doi: org $/ 10.1088 / 1742-6596 / 803 / 1 / 012006$

9. Akeel F., et al. Formal modelling of data integration systems security policies. Data Science and Engineering, 2016, vol. 1, iss. 3, pp. 139-148. doi:10.1007/ s41019-016-0016

10. Anisimov V., Anisimov E., Sonkin M. A Resourceand-time method to optimize the performance of several interrelated operations. International Journal of Applied Engineering Research, 2015, vol. 10, no. 17, pp. 38127-38132.

11. Jaynes $E$. T. Information theory and statistical mechanics. Physical Review. Series II, 1957, vol. 106, no. 4, pp. 620-630.

12. Fishburn Peter C. Nonlinear Preference and Utility Theory. Baltimore, Md., Johns Hopkins University Press, 1988. 259 p.

13. Saurenko T., Anisimov E., Anisimov V., Levina A. Comparing investment projects of innovative developing strategies of municipalities, based on a set of indicators. MATEC Web of Conferences "International Science Conference SPbWOSCE-2017 "Business Technologies for Sustainable Urban Development”, 2018, p. 01038.

14. Gumbel E. J. Statistical theory of extreme values and some practical applications. Applied Mathematics Series. 33. 1st ed. U. S., Department of Commerce, National Bureau of Standards, 1954. $60 \mathrm{p}$. 
удК 004.056.53

doi:10.31799/1684-8853-2019-5-18-23

Модели прогнозирования опасности деструктивных воздействий на информационные процессы в системах управления

В. Г. Анисимов ${ }^{a}$, доктор техн. наук, профессор, orcid.org/ 0000-0002-5097-4618, an-33@yandex.ru

Е. Г. Анисимов ${ }^{\sigma}$, доктор техн. наук, профессор, orcid.org/ 0000-0002-6527-2352

T. Н. Сауренко ${ }^{\sigma}$, доктор экон. наук, заведующий кафедрой, orcid.org/ 0000-0003-1736-7178

Е. А. Зотова ${ }^{\mathrm{a}}$, ассистент, orcid.org/ 0000-0003-4539-4253

а Санкт-Петербургский политехнический университет Петра Великого, Политехническая ул., 29, Санкт-Петербург, 195251, РФ

бРоссийский университет дружбы народов, Миклухо-Маклая ул., 6, Москва, 117198, РФ

Введение: одним из побочных эффектов внедрения современных информационных технологий в управление экономическими, социальными, организационно-техническими и техническими системами является обострение зависимости качества управления от преднамеренных и случайных деструктивных воздействий, нарушающих целостность, конфиденциальность и доступность используемой информации. Это определяет актуальность развития соответствующих систем обеспечения информационной безопасности. Обоснование путей развития таких систем требует решения проблем сравнительной оценки опасности соответствующих деструктивных воздействий и затрат на их предотвращение. Цель исследования: прогнозирование опасности деструктивных воздействий на информационные процессы в системах управления. Методы: представление деструктивных воздействий в виде случайной последовательности событий, приводящих к сбоям информационных процессов. Последствия сбоев также представляются соответствующими случайными величинами. Результаты: предложены методические подходы к построению моделей прогнозирования временных и объемных характеристик ущербов от деструктивных воздействий на информационные процессы в системах управления экономическими, социальными, организационно-техническими и техническими системами. В этих моделях опасность указанных деструктивных воздействий предлагается оценивать вероятностью наступления в некоторый момент времени деструктивного события и обусловленной им величиной ущерба. В основу построения моделей прогнозирования положено представление показателей ущербов в форме скачкообразных функций от времени. В основу конструктивного представления этих функций положен условно-детерминистический подход. Полнота использования априорной информации при определении конкретных параметров функций ущерба обеспечивается применением принципа максимума неопределенности. Мерой неопределенности принята энтропия. Развитием условно-детерминистического подхода для более высоких уровней неопределенности явился стохастический подход. На его основе предложены соответствующие различным информационным ситуациям классы стохастических моделей, позволяющих оценивать не только ожидаемые величины показателей ущербов вследствие непринятия мер обеспечения информационной безопасности при управлении целенаправленными системами, но и их вероятностные характеристики. Практическая значимость: предлагаемые подходы являются базой для создания конкретных моделей и методик в интересах обоснования решений по формированию состава структуры организации и управления функционированием подсистем обеспечения информационной безопасности.

Ключевые слова - информационные системы, информационная безопасность, деструктивные воздействия, ущерб, модели прогнозирования ущерба.

Для цитирования: Anisimov V. G., Anisimov E. G., Saurenko T. N., Zotova E. A. Models of forecasting destructive influence risks for information processes in management systems. Информационно-управляющие системы, 2019, № 5, с. 18-23. doi:10.31799/16848853-2019-5-18-23

For citation: Anisimov V. G., Anisimov E. G., Saurenko T. N., Zotova E. A. Models of forecasting destructive influence risks for information processes in management systems. Informatsionno-upravliaiushchie sistemy [Information and Control Systems], 2019, no. 5, pp. 18-23. doi:10.31799/1684-8853-2019-5-18-23

\section{УВАЖАЕМЫЕ АВТОРЫ!}

Научные базы данных, включая SCOPUS и Web of Science, обрабатывают данные автоматически. С одной стороны, это ускоряет процесс обработки данных, с другой - различия в транслитерации ФИО, неточные данные о месте работы, области научного знания и т. д. приводят к тому, что в базах оказывается несколько авторских страниц для одного и того же человека. В результате для всех по отдельности считаются индексы цитирования, снижая рейтинг ученого.

Для идентификации авторов в сетях Thomson Reuters проводит регистрацию с присвоением уникального индекса (ID) для каждого из авторов научных публикаций.

Процедура получения ID бесплатна и очень проста, есть возможность провести регистрацию на 12-ти языках, включая русский (чтобы выбрать язык, кликните на зеленое поле вверху справа на стартовой странице): https://orcid.org 


\title{
Ограничения утечки информации посредством неочевидных функций смартфона Android 5
}

\author{
Т. М. Татарникова а, доктор техн. наук, доцент, orcid.org/0000-0002-6419-0072, tm-tatarn@yandex.ru

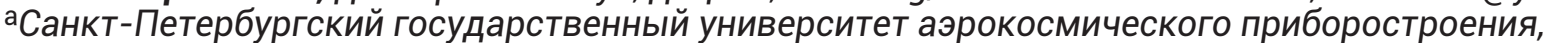 \\ Б. Морская ул., 67, Санкт-Петербург, 190000, РФ
}

\begin{abstract}
Постановка проблемы: данные от гироскопического датчика и датчика ускорения смартфона обычно не рассматриваются в качестве возможного варианта утечки информации, что делает владельцев гаджетов, работающих под операционной системой Android 5 и ниже, уязвимыми к потере ценной информации. Цель исследования: предложение практического способа противодействия считыванию информации со смартфона по сторонним каналам и реализация мобильного приложения, способствующего предотвращению возможности утечки информации владельца гаджета по побочным каналам передачи информации. Результаты: выполнен обзор исследований, демонстрирующих уязвимость смартфонов Android 5 к утечкам по сторонним каналам, с применением техники акустического криптоанализа. Показано, что в современных работах применение акустического криптоанализа шума, издаваемого клавиатурой или микроэлектронными компонентами компьютера, позволяет реализовать утечку ценной информации средствами смартфона, находящегося рядом с атакуемым компьютером. Разработано мобильное приложение, которое создает активные помехи в виде вибро- и аудиосигнала вредоносному приложению, обращающемуся к акселерометру и гироскопу в целях съема информации. Приведены результаты эксперимента, демонстрирующие способность приложения успешно поставить помехи внутренним датчикам смартфона посредством обращения к вибро- и аудиовыходам и предотвратить атаки по сторонним каналам. Практическая значимость: наличие предлагаемого приложения на смартфоне Android 5 позволит более безопасно вести переговоры, вводить пароли, набирать секретную информацию на клавиатуре компьютера, если смартфон находится в непосредственной близости от нее.
\end{abstract}

Ключевые слова - утечка информации, сторонний канал, акустический криптоанализ, смартфон, гироскоп, акселерометр, мобильное приложение, операционная система Android 5.

Для цитирования: Татарникова Т. М. Ограничения утечки информации посредством неочевидных функций смартфона Android 5. Информационно-управляющие системы, 2019, № 5, с. 24-29. doi:10.31799/1684-8853-2019-5-24-29

For citation: Tatarnikova T. M. Restricting data leakage through non-obvious features of Android 5 smartphone. Informatsionnoupravliaiushchie sistemy [Information and Control Systems], 2019, no. 5, pp. 24-29 (In Russian). doi:10.31799/1684-8853-2019-524-29

\section{Введение}

Роль мобильного телефона в жизни человека сегодня сложно переоценить. Многие люди уже не представляют свой рабочий день и досуг без этого аппарата. Благодаря «умным» функциям компьютера современный смартфон стал своего рода мобильным мини-офисом в кармане.

Смартфоны оперируют конфиденциальной информацией своего владельца. Если передача речи и данных со смартфона решается средствами криптографии, то возможность подслушивания в окрестностях телефона остается. Гироскопический датчик (гироскоп) и датчик ускорения (акселерометр), которые являются неотъемлемыми элементами современного смартфона, можно превратить в своеобразный микрофон. Чувствительность этих датчиков к вибрациям позволяет фиксировать звуки, из которых впоследствии можно извлечь полезную информацию [1].

В статье предлагаются практический способ противодействия считыванию информации со смартфона по сторонним каналам и реализация этого способа в виде программного приложения для смартфона. Объектом исследования является смартфон под управлением операционной системы вплоть до версии Android 5. Проблема может стать актуальной и для операционных систем Android 6 и выше в случае наличия у приложения разрешений на доступ к гироскопу и акселерометру.

\section{Характеристика атак по сторонним каналам}

Введем несколько ключевых определений.

Сторонние каналь - это характеристики физических устройств или систем, которые имеют потенциальную опасность и упускаются из вида. Например, сторонним каналом может быть светодиод на маршрутизаторе, который мигает в такт передаваемой информации, или звук нажатия клавиш на клавиатуре.

Атака по стороннил каналал - это атака, направленная на особенности практической реализации устройства. Для ее выполнения используется информация о физических процессах в устройстве. 
Акустический криптоанализ - это разновидность пассивных атак по сторонним каналам, которая направлена на извлечение полезной информации из звуков, производимых компьютером или иными устройствами. Сегодня в этом направлении делается упор на анализ шума, издаваемого клавиатурой или микроэлектронными компонентами компьютера.

За последние несколько лет в области акустического криптоанализа появился ряд результатов, описывающих действенность атак посредством гироскопа и акселерометра смартфона, расположенного рядом с атакуемым объектом или субъектом. Полученные с этих датчиков показатели позволяют достаточно точно восстанавливать отдельные слова, произносимые в замкнутом пространстве, например комнате, а также идентифицировать голоса отдельных людей.

Акселерометр способен также фиксировать вибрации при нажатии клавиш клавиатуры атакуемого компьютера, а гироскоп - фильтровать шум из поступивших данных. Используя специальные техники, можно составить таблицу соответствий «издаваемая вибрация - номер нажатой клавиши», а попарный анализ вибрации позволит установить расстояние от смартфона до каждой клавиши. При использовании такого метода можно восстановить целиком клавиатуру или значимую ее часть, а злоумышленник получает доступ к конфиденциальной информации.

Надо иметь в виду, что к показателям датчиков имеют доступ приложения, установленные на смартфоне. Это означает, что для организации прослушивания атакуемого достаточно внедрить в его смартфон вредоносное приложение, которое будет принимать данные от датчиков.

\section{Обзор атак по сторонним каналам смартфона}

В работе [1] описывается возможность использования гироскопа как микрофона для прослушивания кого-либо или чего-либо. В работе [2] изучалась возможность считывания информации акселерометром, который поможет узнать пароль, вводимый на компьютере. В исследовании работ $[3,4]$ использовались умные часы, которые находились в непосредственной близости от клавиатуры и считывали вводимые на ней PIN-коды.

Опубликованные результаты экспериментов [5, 6] ставят вне сомнения уязвимость клавиатур аппаратных средств ввода персональных компьютеров, телефонов и терминалов банковского обслуживания, в том числе банкоматов, к акустическим атакам, учитывающим различное звучание клавиш.

Еще больший интерес представляют научные исследования на тему акустических атак на высо- кочастотные звуки, издаваемые микроэлектронной начинкой аппаратных средств персональных компьютеров и других устройств. В работе [7] демонстрируется, что микроэлектронные элементы схем компьютеров при работе испускают звуковые сигналы, считывание которых высокочувствительным микрофоном с последующим анализом полученных данных может привести к извлечению злоумышленниками секретной информации. В частности, были проанализированы ультразвуковые сигналы, издаваемые конденсаторами, индукционными элементами материнской платы и центральным процессором во время выполнения криптографических операций алгоритма шифрования RSA. В 2013 г. описанная атака была успешно осуществлена. Опубликованы [8] ее результаты: в течение одного часа удалось получить 4096-битный секретный ключ RSA атакуемого портативного компьютера, расположив смартфон рядом с ним.

Описан [9] результативный способ определения того, какие именно клавиши были задействованы на сенсорной клавиатуре операционной системы Android. Способ учитывает измерения смещений, покачиваний и вибрации встроенного акселерометра. В действительности у каждой экранной клавиши есть эксклюзивная картина изменений углов по трем осям $X, Y, Z$, что и может быть идентифицировано. Точность зависит от модели телефона. При этом исследователи добились $71,5 \%$ точности для 10-кнопочной клавиатуры. Оставшиеся 28,5 \% составили ошибки из-за близкого расположения клавиш. В работе также сделаны выводы о том, что на более крупных устройствах, таких как планшеты, должно быть легче производить распознавание нажатий дисплея.

Актуальность настоящего исследования заключается в том, что данные от акселерометров обычно не рассматривались в качестве возможного варианта атаки устройства, и значит, легко доступны любому приложению на любом смартфоне или планшете [10]. Также стоит отметить, что сторонний канал является серьезной угрозой для безопасности Android, поскольку данные гироскопа и акселерометра доступны через прикладной программный интерфейс DeviceOrientation, который реализован в Android 3.0, IOS 4.2 и во всех современных браузерах. Это свидетельствует о возможном похищении важной информации при ее вводе в браузере [11].

\section{Обзор существующих решений}

Можно выделить следующие варианты противодействия атакам по сторонним каналам:

— клетки Фарадея, «воздушные зазоры», фильтры элементов питания. Однако эти методы нель- 
зя назвать эффективными против акустического криптоанализа. Установлено, что если устройство, защищенное клеткой Фарадея по стандарту TEMPEST, результативно противостоит любому электромагнитному излучению, то акустическое излучение легко проникает сквозь решетки системы охлаждения [12];

- проигрывание дополнительных звуков в хаотичном порядке аналогичной частоты и формы исходному звуку с целью завуалировать его. При этом желательно применять не менее пяти различных записей для каждой кнопки клавиатуры, чтобы свести к минимуму риск распознавания при помощи быстрого преобразования Фурье [3];

- акустический сейф, изолирующий телефон от внешнего воздействия. Недостаток: с телефоном нельзя взаимодействовать, когда он находится в данном приспособлении [13];

- установка антивируса как элемента комплексной защиты. Недостаток: антивирус не имеет доступа к разрешениям, которые выдаются приложениям при их установке. Соответственно, антивирус не может запретить приложению доступ к гироскопу и акселерометру и тем более поставить им помехи [14].

\section{Предлагаемое решение}

При установке приложения на смартфон пользователю предлагается ознакомиться с разрешениями, которые оно запрашивает.

Необходимость предлагаемого решения для смартфонов под операционной системой Android 5 обусловлена тем, что для данной версии операционной системы и версий, которые ей предшествовали, не предусмотрена настройка разрешений для приложений. Эта уязвимость приводит к тому, что любому приложению на смартфоне будут доступны данные, получаемые с гироскопа и акселерометра. Таким образом, потенциальными жертвами потери секретной информации становится большой круг пользователей, поскольку доля смартфонов, работающих под данной версией (и ниже), все еще составляет большую часть из всех телефонов операционной системы Android 5.

Предлагаемое приложение позволяет создавать активные помехи в виде вибро- и аудиосигнала. При запуске приложения автоматически запускается звук и (или) вибрация для создания помех вредоносному приложению, обращающемуся к акселерометру и гироскопу в целях съема информации [15].

Наличие предлагаемого приложения на смартфоне позволит более безопасно вести переговоры, вводить пароли, набирать секретную информацию на клавиатуре компьютера, если смартфон находится в непосредственной близости от нее.

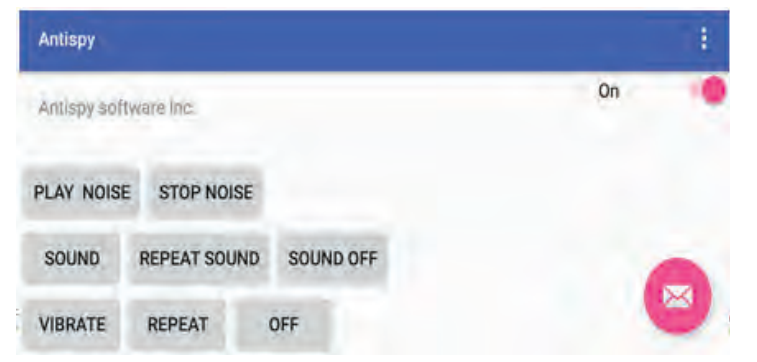

- Puc. 1. Меню разработанного приложения

- Fig. 1. Menu developed application

В разработанном приложении, интерфейс которого представлен на рис. 1, выполняются функции посредством следующих кнопок:

- PLAY NOISE - подача белого шума;

- STOP NOISE - отключение белого шума;

- SOUND - подача акустического сигнала;

- SOUND OFF - отключение акустического сигнала;

- REPEAT SOUND - подача случайным образом воспроизводимого акустического сигнала;

- VIBRATE - подача вибросигнала;

- REPEAT - подача случайным образом воспроизводимого вибросигнала;

- OFF - выключение подачи вибросигнала.

Включение и выключение приложения пользователь производит на свое усмотрение, равно как и выбор варианта постановки помех.

На выходе с гироскопа и акселерометра формируется файл с расширением csv, в котором представлен набор значений координат по трем осям $X, Y, Z$. По полученным значениям строятся графики, позволяющие убедиться, что значения координат изменились.

\section{Описание и результаты проведенного эксперимента}

Эксперимент проводился при подаче звукового сигнала из акустических колонок на имеющихся частотах $f=\{400,200,100\}$ Гц с уровнем громкости 100 дБ из соображений слышимости звукового сигнала. Звуковой сигнал подается и отключается с периодом 5 с.

На фотографии (рис. 2) показана установка для исследования. Показания гироскопа смартфона YotaPhone 2 приведены на рис. 3 и 4.

На рис. 3, $а$ представлен график состояния гироскопа смартфона при подаче на него звукового сигнала. График на рис. 3, б демонстрирует изменение значений координат по трем осям $X, Y$, $Z$ состояния гироскопа с тем же звуковым сигналом и работающим приложением. Приложение ставит вибро- и (или) аудиопомехи, тем самым скрывая полезный звуковой сигнал. 


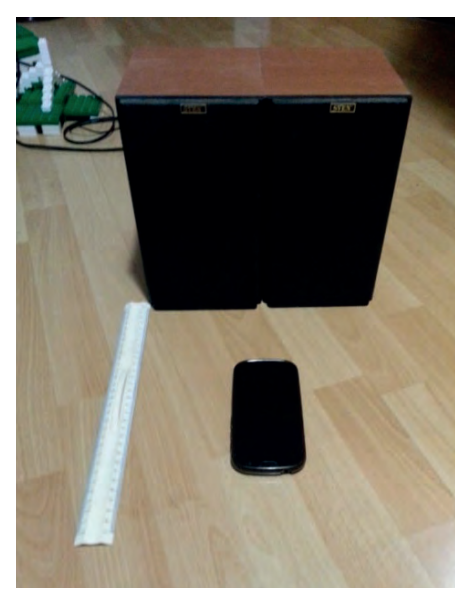

- Puc. 2. Установка для эксперимента

- Fig. 2. The setup for the experiment

a) $\omega$, рад/с

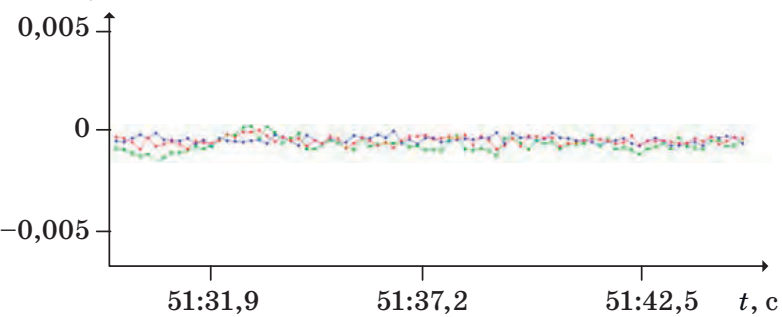

б) $\omega, \mathrm{paд} / \mathrm{c}$

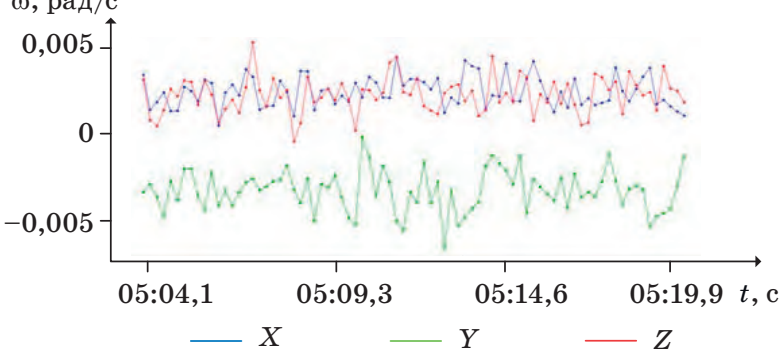

Puc. 3. Гироскоп - состояние с акустическим сигналом при $f=400$ Гц: $a-$ без приложения; $\sigma$ - во время работы приложения

- Fig. 3. Gyroscope - a state with an acoustic signal at $f=400 \mathrm{~Hz}: a-$ without application; $\sigma-$ while the application is running

Сравнение наборов значений координат по трем осям $X, Y, Z$ для гироскопа с речью, подаваемой на микрофон смартфона YotaPhone 2 (рис. 4, a), и состояния гироскопа с той же речью и работающим приложением (рис. 4, б) свидетельствует об изменении значений координат. В данном эксперименте показана действенность вибропомех на запись полезного речевого сигнала.

Показания акселерометра смартфона YotaPhone 2 приведены на рис. 5 и 6.

На рис. 5, а показан график состояния акселерометра смартфона с акустическим сигналом. a) $\omega$, рад/с

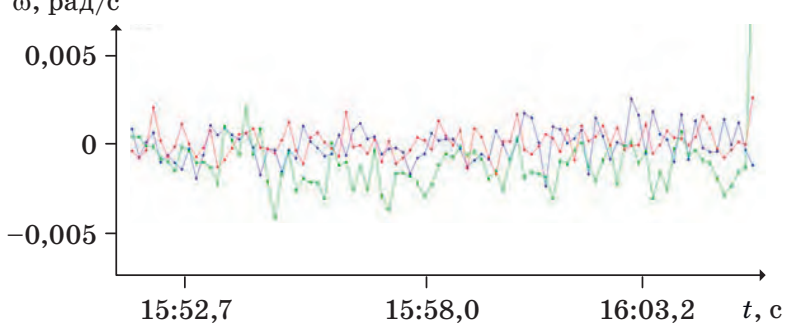

б) $\omega, \mathrm{paд} / \mathrm{c}$

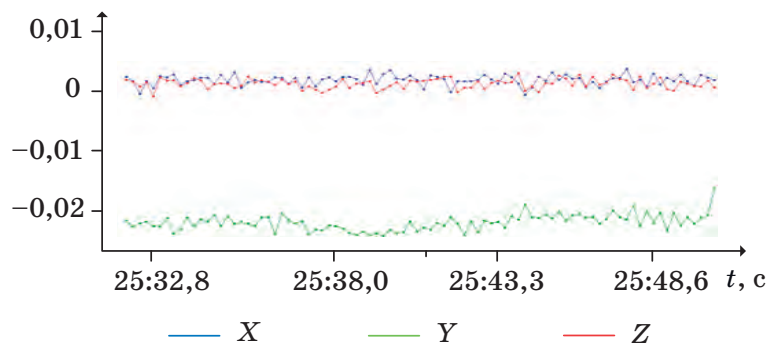

- Puc. 4. Гироскоп - состояние с речью: $a$ - без приложения; б - во время работы приложения

- Fig. 4. Gyroscope - a state with voice: $a$ - without application; $\sigma$ - while the application is running

a) $\omega$, рад/с

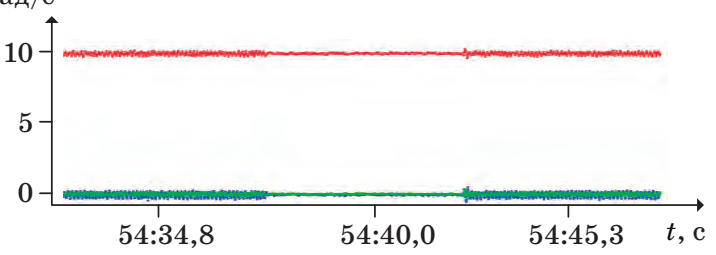

б) $\omega$, рад/с

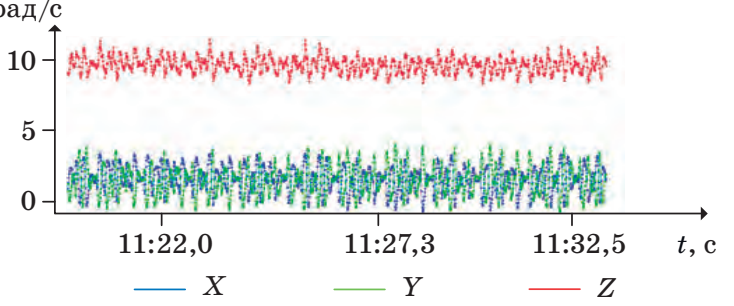

Puc. 5. Акселерометр - состояние с акустическим сигналом при $f=400$ Гц: $a-$ без приложения; б - во время работы приложения

- Fig. 5. Accelerometer - a state with an acoustic signal at $f=400 \mathrm{~Hz}: a-$ without application; $\sigma-$ while the application is running

График на рис. 5, б демонстрирует изменение значений координат по трем осям $X, Y, Z$ состояния акселерометра с тем же акустическим сигналом и работающим приложением, которое посредством установки вибро- и (или) аудиопомех делает невозможным запись полезного звукового сигнала.

Сравнение наборов значений координат по трем осям $X, Y, Z$ для состояния акселерометра с речью (рис. 6, a) и состояния акселерометра с той же речью и работающим приложением 
a) $\omega$, рад/с

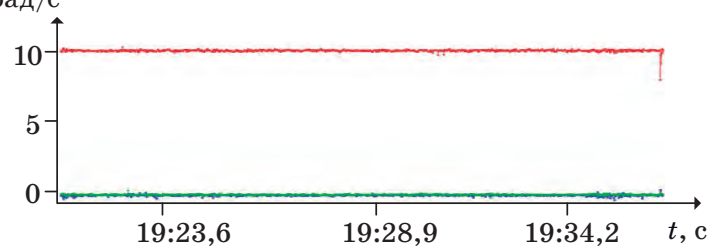

б) $\omega$, рад/c

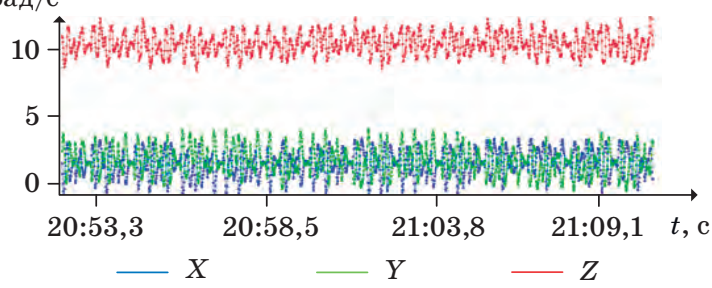

- Pис. 6. Акселерометр - состояние с речью: $a$ - без приложения; б - во время работы приложения

- Fig. 6. Accelerometer - state with voice: $a$ - without application; $\sigma$ - while the application is running

(рис. 6, б) свидетельствует об изменении значений координат во втором случае. Таким образом, результаты эксперимента демонстрируют, что установка вибро- и (или) аудиопомех позволяет скрыть полезный речевой сигнал.

Результаты эксперимента при подаче звукового сигнала из акустических колонок на часто-

\section{Литература}

1. Xu Z., Bai K., Zhu S. TapLogger: inferring user inputs on smartphone touchscreens using on-board motion sensors. Proceedings of the Fifth ACM Conference on Security and Privacy in Wireless and Mobile Networks (WISEC '12), Tucson, April 16-18, 2012, pp. 113-124.

2. Michalevsky Y., Boneh D. Gyrophone: recognizing speech from gyroscope signals. Proceedings of the 23rd USENIX Security Symposium, San Diego, August 20-22, 2014, pp. 1053-1067.

3. Marquardt P., Verma A., Carter H., Traynor P. (sp) iPhone: Decoding vibrations from nearby keyboards using mobile phone accelerometers. Proceedings 18th ACM Conference on Computer and Communications Security, 2011, pp. 551-562.

4. Maiti A., Jadliwala M., He J., and Bilogrevic I. (smart) watch your taps: side-channel keystroke inference attacks using smartwatches. Proceedings of the 2015 ACM International Symposium on Wearable Computers, ACM, 2015, pp. 27-30.

5. Beltramelli T. Deep-Spying: Spying using Smartwatch and Deep Learning. Copenhagen, IT University of Copenhagen, 2015. $125 \mathrm{p}$.

6. Asonov D., Agrawal R. Keyboard acoustic emanations. Proceedings of the IEEE Symposium on Security and Privacy, 2004, pp. 3-11. тах $f$, равных 200 и 100 Гц, также показывают его изменение при запуске приложения.

\section{Заключение}

Обзор исследований в интересующей области, а также собственные проведенные исследования подтвердили возможность фиксации входящих звуковых сигналов датчиками акселерометра и гироскопа.

Разработано программное приложение под Android, ставящее помехи внутренним датчикам смартфона при помощи обращения к вибро- и аудиовыходам. Это необходимо для предотвращения возможности утечки информации владельца гаджета по побочным каналам передачи информации. Согласно результатам исследования, представленное приложение способно успешно поставить помехи и предотвратить перечисленные атаки.

Выбор версии Android 5 и ниже обусловлен тем, что, во-первых, на сегодня это программное обеспечение является самым распространенным на смартфонах, а во-вторых, в данных версиях отсутствует возможность контроля за доступом к указанным датчикам со стороны пользователя портативного устройства, в чем видится существенная уязвимость Android 5.

7. Yang S. Researchers recover typed text using audio recording of keystrokes. 2005. http://www.berkeley. edu/news/media/releases/2005/09/14_key.shtml (дата обращения: 03.05.2019).

8. Shamir A., Tromer E. Acoustic cryptanalysis on nosy people and noisy machines. 2004. http://people.csail. mit.edu/tromer/acoustic (дата обращения: 03.05.2019).

9. Genkin D., Shamir A., Tromer E. RSA Key Extraction via Low-Bandwidth Acoustic Cryptanalysis. In: Garay J. A., Gennaro R. (eds). Advances in Cryptology - CRYPTO 2014. Lecture Notes in Computer Science, vol. 8616. Springer, Berlin, Heidelberg. doi. org/10.1007/978-3-662-44371-2_25

10. Cai L., and Chen H. Touch Logger: Inferring keystrokes on touch screen from smartphone motion. Proceedings of the 6th USENIX Conference on Hot Topics in Security (HotSec'11), CA, Berkeley, 2011, pp. 1-6.

11. Голощапов А. Google Android. Создание приложе ний для смартфонов и планшетных ПК. СПб., БХВ-Петербург, 2014. 911 с.

12. Cai L., and Chen H. On the practicality of motion based keystroke inference attack. Proceedings of the 5th International Conference on Trust and Trustworthy Computing (TRUST'12), Berlin, Heidelberg, 2012, pp. 273-290.

13. Goller G., and Sigl G. Side channel attacks on smartphones and embedded devices using standard radio equipment. Proceedings of the 6th International Work- 
shop "Constructive Side-Channel Analysis and Secure Design”, COSADE 2015, Berlin, 2015, pp. 255-270.

14. Татарникова Т. М., Журавлев А. М. Нейросетевой метод обнаружения вредоносных программ на платформе ANDROID. Програллные продукты и систелы, 2018, № 3, с. 543-547.
15. Poymanova E. D., Tatarnikova T. M. Models and methods for studying network traffic. Proceedings of the XXI International Conference "Wave Electronics and its Application in Information and Telecommunication Systems" (WECONF-2018), Saint-Petersburg, Nov 26-30, 2018. doi:10.1109/WECONF.2018. 8604470

\section{UDC 004.7}

doi:10.31799/1684-8853-2019-5-24-29

\section{Restricting data leakage through non-obvious features of Android 5 smartphone}

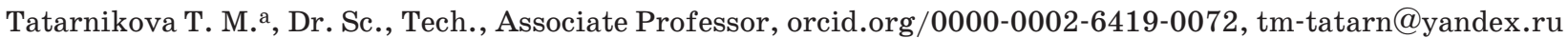
aSaint-Petersburg State University of Aerospace Instrumentation, 67, B. Morskaia St., 190000, Saint-Petersburg, Russian Federation

Introduction: The data from the gyroscopic sensor and acceleration sensor of a smartphone are seldom considered as a possible information leakage, which makes the owners of gadgets working under Android 5 operating system or below vulnerable to losing valuable information. Purpose: Offering a practical way to counteract the reading of data from a smartphone via third-party channels, and developing a mobile application which would help prevent the leakage of information from the gadget owner via side channels of information transfer. Results: A review of studies was performed demonstrating the vulnerability of Android 5 smartphones to leaks through third-party channels using acoustic cryptanalysis techniques. It is shown that in modern works, the use of acoustic cryptanalysis of noise emitted by a keyboard or by microelectronic components of a computer allows you to arrange the leakage of valuable data via a smartphone located next to the computer under attack. A mobile application has been developed which creates active interference in the form of vibration and audio signal to the malicious application which accesses the accelerometer and gyroscope in order to retrieve information. The results of an experiment are given, demonstrating the ability of the application to successfully interfere with the internal sensors of a smartphone by addressing its vibrating output and audio output, and prevent the attacks over third-party channels. Practical relevance: The proposed application installed on a smartphone will allow you to communicate more safely, enter passwords and type secret information on a computer keyboard with a smartphone in its close proximity.

Keywords - information leakage, third-party channel, acoustic cryptanalysis, smartphone, gyroscope, accelerometer, mobile application, Android 5 operating system.

For citation: Tatarnikova T. M. Restricting data leakage through non-obvious features of Android 5 smartphone. Informatsionnoupravliaiushchie sistemy [Information and Control Systems], 2019, no. 5, pp. 24-29 (In Russian). doi:10.31799/1684-8853-2019-5-24-29

\section{References}

1. Xu Z., Bai K., Zhu S. TapLogger: inferring user inputs on smartphone touchscreens using on-board motion sensors. Proceedings of the Fifth ACM Conference on Security and Privacy in Wireless and Mobile Networks (WISEC '12), Tucson, April 16-18, 2012, pp. 113-124.

2. Michalevsky Y., Boneh D. Gyrophone: recognizing speech from gyroscope signals. Proceedings of the 23rd USENIX Security Symposium, San Diego, August 20-22, 2014, pp. 1053-1067.

3. Marquardt P., Verma A., Carter H., Traynor P. (sp) iPhone: Decoding vibrations from nearby keyboards using mobile phone accelerometers. Proceedings 18th ACM Conference on Computer and Communications Security, 2011, pp. 551-562.

4. Maiti A., Jadliwala M., He J., and Bilogrevic I. (smart) watch your taps: side-channel keystroke inference attacks using smartwatches. Proceedings of the 2015 ACM International Symposium on Wearable Computers, ACM, 2015, pp. 27-30.

5. Beltramelli T. Deep-Spying: Spying using Smartwatch and Deep Learning. Copenhagen, IT University of Copenhagen, 2015. $125 \mathrm{p}$

6. Asonov D., Agrawal R. Keyboard acoustic emanations. Pro ceedings of the IEEE Symposium on Security and Privacy, 2004 , pp. 3-11.

7. Yang S. Researchers recover typed text using audio recording of keystrokes. 2005. Available at: http://www.berkeley.edu/news/ media/releases/2005/09/14 key.shtml (accessed 03 May 2019).

8. Shamir A., Tromer E. Acoustic cryptanalysis on nosy people and noisy machines. 2004. Available at: http://people.csail. mit.edu/tromer/acoustic (accessed 03 May 2019).

9. Genkin D., Shamir A., Tromer E. RSA Key Extraction via Low-Bandwidth Acoustic Cryptanalysis. In: Garay J. A.,
Gennaro R. (eds). Advances in Cryptology - CRYPTO 2014. Lecture Notes in Computer Science, vol. 8616. Springer, Berlin, Heidelberg. doi.org/10.1007/978-3-662-44371-2_25

10. Cai L. and Chen H. Touch Logger: Inferring keystrokes on touch screen from smartphone motion. Proceedings of the 6th USENIX Conference on Hot Topics in Security (Hot Sec'11), CA, Berkeley, 2011, pp. 1-6.

11. Goloshchapov A. Google Android. Sozdaniye prilozheniy dlya smartfonov $i$ planshetnykh PK [Create apps for smartphones and tablets]. Saint-Petersburg, BHV-Petersburs Publ., 2014. 911 p. (In Russian).

12. Cai L., and Chen H. On the practicality of motion based keystroke inference attack. Proceedings of the 5th International Conference on Trust and Trustworthy Computing (TRUST'12), Berlin, Heidelberg, 2012, pp. 273-290.

13. Goller G., and Sigl G. Side channel attacks on smartphones and embedded devices using standard radio equipment. Pro ceedings of the 6th International Workshop "Constructive Side-Channel Analysis and Secure Design", COSADE 2015, Berlin, 2015, pp. 255-270.

14. Tatarnikova T. M., Zhuravlev A. M. A neural network method for detecting malicious programs on the Android platform. Software \& Systems, 2018, no. 3, pp. 543-547 (In Russian).

15. Poymanova E. D., Tatarnikova T. M. Models and methods for studying network traffic. Proceedings of the XXI Internation al Conference "Wave Electronics and its Application in Infor mation and Telecommunication Systems" (WECONF-2018), Saint-Petersburg, Nov 26-30, 2018. doi:10.1109/WECONF. 2018.8604470 


\title{
Подход к реализации распределенной системы виртуальных машин для самоорганизующихся сетей
}

\author{
С. В. Кулешова, доктор техн. наук, главный научный сотрудник, orcid.org/0000-0002-8454-5598 \\ А. А. Зайцева ${ }^{\mathrm{a}}$ канд. техн. наук, старший научный сотрудник, orcid.org/0000-0002-1345-8550, \\ vaz1976@mail.ru \\ И. О. Шальнева, аспирант, orcid.org/0000-0001-9383-1089 \\ а Санкт-Петербургский институт информатики и автоматизации РАН, 14-я линия В. О., 39, \\ Санкт-Петербург, 199178, РФ
}

\begin{abstract}
Введение: активные данные, представляя собой фрагменты исполнимого кода, передаваемого между узлами активной сети, являются эффективным механизмом функционирования программно-реконфигурируемых распределенных систем. Ранее в работах, посвященных активным данным, не уделялось достаточное внимание реализации среды выполнения (процессора) для исполнимого кода активных данных, а также вопросам построения гипервизоров и балансировки нагрузки в распределенных системах. Цель: разработка принципов построения виртуальных машин активных данных, обеспечивающих реконфигурируемость конечных устройств и гибкость сети в целом, определение возможности использования существующих подходов к балансировке нагрузки для сетей с активными данными. Методы: использованы принципы построения программно-определяемых систем, концепция активных данных, теоретические основы и технологии виртуализации. Результаты: рекомендовано в качестве среды выполнения активных данных использовать распределенную систему виртуальных машин, для построения которой выбран объектно-ориентированный подход к созданию распределенных приложений. При этом каждый узел такой распределенной системы виртуальных машин может выступать в качестве ведущего и ведомого узла при объектном взаимодействии. На основе сформулированного подхода предложено решение задачи построения сети ретрансляторов с применением активных данных, при этом беспилотный летательный аппарат рассматривается как элемент активной инфокоммуникационной сети, поддерживающий технологию активных данных. Так как распределенная система виртуальных машин допускает асимметричное распределение узлов децентрализованной сети, для распределенной системы, узлами которой являются беспилотные летательные аппараты и узел управления, разработан метод управления величиной асимметричности путем создания объектов различного уровня декомпозиции. Практическая значимость: представленные методы обеспечивают возможность управления ресурсопотреблением узлов распределенной программно-реконфигурируемой сети и количества передаваемых сетевых данных. Для динамического управления степенью загруженности узлов сети разработан вариант архитектуры менеджера ресурсов.
\end{abstract}

Ключевые слова - активные данные, виртуальная машина, распределенная сеть, беспилотный летательный аппарат, передача данных, программно-определяемые системы, самоорганизующиеся сети.

Для цитирования: Кулешов С. В., Зайцева А. А., Шальнев И. О. Подход к реализации распределенной системы виртуальных машин для самоорганизующихся сетей. Информационно-управляющие системы, 2019, № 5, с. 30-37. doi:10.31799/1684-88532019-5-30-37

For citation: Kuleshov S. V., Zaytseva A. A., Shalnev I. O. Distributed system of virtual machines for self-organized networks. Informatsionno-upravliaiushchie sistemy [Information and Control Systems], 2019, no. 5, pp. 30-37 (In Russian). doi:10.31799/16848853-2019-5-30-37

\section{Введение}

Рост качества и скорости каналов связи делает популярными технические решения, основанные на распределенных приложениях с неравномерным распределением алгоритмической составляющей между узлами вычислительной сети.

Одновременно с этим новые объективные потребности создания программно-определяемых систем взамен морально устаревших программно-управляемых [1] диктуют необходимость исследования подходов, расширяющих функциональные возможности программного кода по изменению параметров аппаратных систем. Одним из таких подходов является подход активных данных [2-3].
Активные данные (АД), представляя собой фрагменты исполнимого кода, передаваемого между узлами активной сети, являются эффективным механизмом функционирования программно-реконфигурируемых распределенных систем. Ранее в работах, посвященных АД, не уделялось достаточное внимание среде выполнения исполнимого кода, а также вопросам построения гипервизоров и балансировки нагрузки в распределенных системах, когда узлы сети являются унифицированными. В данной работе рассматриваются вариант построения распределенной системы виртуальных машин для выполнения АД и существующие алгоритмы балансировки нагрузки в распределенных вычислительных сетях, определяются возможности исполь- 
зования имеющихся подходов к балансировке нагрузки для сетей с АД.

Примечателен тот факт, что в вычислительных системах общего назначения, и в первую очередь в персональных компьютерах, существует обратная тенденция - разработка методов защиты от случайного или злонамеренного выполнения программного кода, расположенного в области данных.

В традиционном подходе (программно-управляемые, а не программно-определяемые вычисления [1]) память, используемую программой, делят на динамически распределяемую область памяти, сегменты данных и сегменты кода $[4,5]$. Указатель команд при этом должен работать в пределах конкретного сегмента кода. Выход указателя за пределы этого сегмента и передача управления в другие области памяти может привести к выполнению процессором случайной последовательности команд, которое прервется только если встретится недопустимая битовая последовательность. В этом случае будет произведено аварийное завершение программы. Возможность выполнения команд из области памяти, в которой размещаются только данные, часто используется для несанкционированного доступа или внедрения вирусов.

Для предотвращения таких атак в операционных системах Linux, Mac OS X, Android и Windows была встроена функция безопасности DEP (Data Execution Prevention, технология предотвращения выполнения данных) [6], запрещающая приложениям доступ к области памяти, в которой размещаются только данные.

Однако в некоторых подходах используется возможность выполнения исполнимого кода в динамически распределяемой области памяти, а точнее, в «стеке» или «куче», например, в процессе оптимизации, динамической компиляции или отладки. Предлагаемая технология АД также основана на исполнении программного кода в области данных.

Одним из вариантов решения задачи обеспечения безопасности может быть применение виртуальных машин и гипервизоров для выполнения исполнимого кода АД.

Целесообразно в качестве среды выполнения АД использовать распределенную систему виртуальных машин, в основе которой выбран объектно-ориентированный подход для создания распределенных приложений.

Каждый узел распределенной системы может выступать в качестве как ведущего, так и ведомого узла при объектном взаимодействии. В этом случае ведомый узел содержит исполнимый код в библиотеках виртуальных машин с предопределенными в нем имплементациями объектов, к которым может обращаться исполнимый код АД. Таким образом, для прикладного программиста появля- ется возможность использовать объекты ведомых узлов, осуществляя управление ими из АД [7].

Компонентным объектом назовем совокупность объектов ведущей и ведомой частей, работающих совместно и представляющих собой единую программную сущность. Часть объекта, расположенная на управляющем узле, ответственна за программный интерфейс (API) описываемой сущности. Вторая часть объекта, расположенная на управляемой стороне, ответственна за функциональное представление сущности. Управление производится путем генерации управляющего кода, который должен быть передан на управляемый узел в пакете АД.

\section{Решение задачи построения сети ретрансляторов с применением АД}

Для формулирования требований к распределенной системе виртуальных машин рассмотрим задачу построения сети передачи данных на базе взаимодействия сети беспилотных летательных аппаратов (БЛА), каждый из которых может управляться и реконфигурироваться АД. Исполнимый код, передаваемый в виде данных, используется для сервисных (управление распространением, маршрутизация и навигация), а также конфигурационных (реконфигурация узлов) операций.

Таким образом, применение концепции АД дает возможность управлять поведением узлов сети (БЛА-ретрансляторов) при помощи самого потока данных без использования выделенного канала [8].

Одним из сценариев использования АД для задач инфокоммуникации является динамическая реконфигурация узлов. С узла-источника $N_{1}$ АД передаются на узел-получатель $N_{3}$. Программа $P$, выполняясь на узле $N_{4}$ (рис. 1$)$, определяет возможность создания нового физического канала связи с узлом $N_{3}$ путем реконфигурирования аппаратной или протокольной части аппаратуры этого узла. В случае если такая реконфигурация будет оптимальной (в смысле минимизации вре-

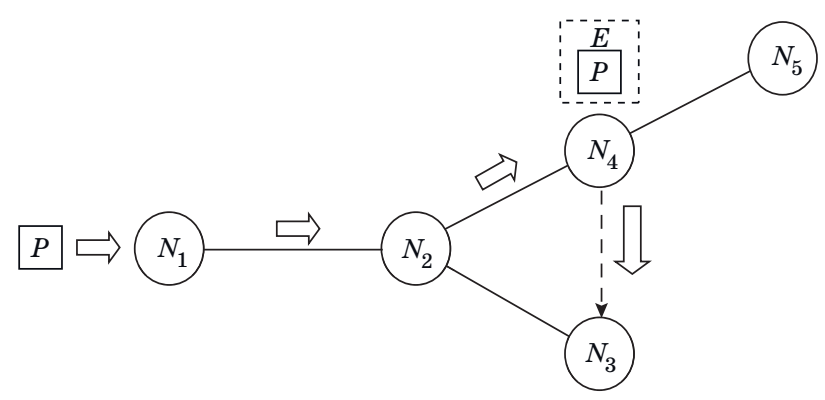

- Puc. 1. Использование динамической реконфигурации [2]

- Fig. 1. The dynamic reconfiguration using [2] 
мени доставки или минимизации ресурсов на осуществление передачи), то производится реконфигурирование и передача АД по вновь созданному физическому каналу связи.

Рассмотрим БЛА как элемент активной инфокоммуникационной сети, поддерживающий технологию АД. В этом случае согласно [2] каждый пакет данных может содержать фрагмент исполнимого кода, который запускается в виртуальной машине для АД - ADVM (Active Data Virtual Machine). Исполнимый код при этом может иметь доступ как к функциям коммуникационной аппаратуры, так и к транспортным функциям БЛА и компонентам стека программного обеспечения полетного контроллера (flight stack).

Асинхронный характер получения пакетов каждым узлом сети вызывает конкуренцию пакетов за право быть выполненным процессором ADVM. Разрешением подобных конфликтов должен заниматься арбитр АД в соответствии с политиками многопоточной обработки. Подобная проблема очень близка к задаче изоляции контекстов в мультизадачных операционных системах и может стать темой дальнейших исследований. В данной работе рассматривается вырожденный случай, и источником управляющих воздействий, передаваемых в АД, упрощенно считается единственный доверенный узел. В этом случае арбитраж активных пакетов заметно упрощается, а необходимостью переключения контекстов и сохранения их состояния можно пренебречь.

\section{Управление степенью асимметричности децентрализованной сети}

Рассмотрим возможность управления степенью асимметричности децентрализованной сети на примере построения распределенной системы, состоящей из управляемых (БЛА) и управляющих узлов. Разберем два варианта реализации задачи пролета БЛА по маршруту. В первом случае управляемый узел (БЛА) обладает большей алгоритмической составляющей, и программисту при реализации управляющего алгоритма достаточно вызвать один метод - полет по точкам маршрута. Во втором случае программа БЛА оперирует более низкоуровневыми примитивами: переместиться вперед, повернуться на заданный курсовой угол и т. п. Здесь алгоритмическая составляющая такого узла может быть меньше.

Опишем величину асимметричности децентрализованной сети. Величина алгоритмической составляющей узла определяется объемом кода вызываемых функций объектов (методов), доступных для вызова кодом из пакетов АД:

$$
l\left(x_{c}\right)=\sum_{i=1}^{n} l\left(m_{i}\right)
$$

где $l\left(x_{c}\right)$ - объем программных компонентов узла; $m_{i}$ - описание $i$-го метода; $l\left(m_{i}\right)$ - объем программных компонентов метода $m_{i} ; n-$ количество методов, необходимое для реализации узла.

Алгоритмическую составляющую АД оценим через длину исполнимого байт-кода (bytecode) в пакетах АД $l\left(x_{\mathrm{Aд}}\right)$. Тогда величину асимметричности децентрализованной сети $T$ определим через отношение

$$
T=\frac{l\left(x_{\mathrm{Aд}}\right)}{\sum_{i=1}^{n} l\left(m_{i}\right)} .
$$

Для исполнения управляющего кода, принимаемого в пакетах АД, можно использовать интерпретатор, выполняющий операции, указанные в исходной программе, над входными данными (рис. 2).

Существует отдельный вид языкового процессора, называемый гибридным компилятором, который объединяет в себе компиляцию и интерпретацию (рис. 3). Исходная программа должна сначала компилироваться во внутреннее представление, называемое байт-кодом. Сформированный байт-код (рис. 4) интерпретируется виртуальной машиной [9].

Внутреннее представление обычно является набором базовых команд, напоминающих машинно-ориентированные ассемблерные. Виртуальная машина представляется как целевая архитектура для таких команд, реализованная программно на архитектуре процессора узла. Целый класс языков программирования, таких как Java, C\#, LISP

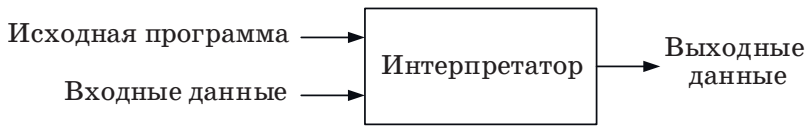

- Puc. 2. Принцип работы интерпретатора

- Fig. 2. The principle of the interpreter

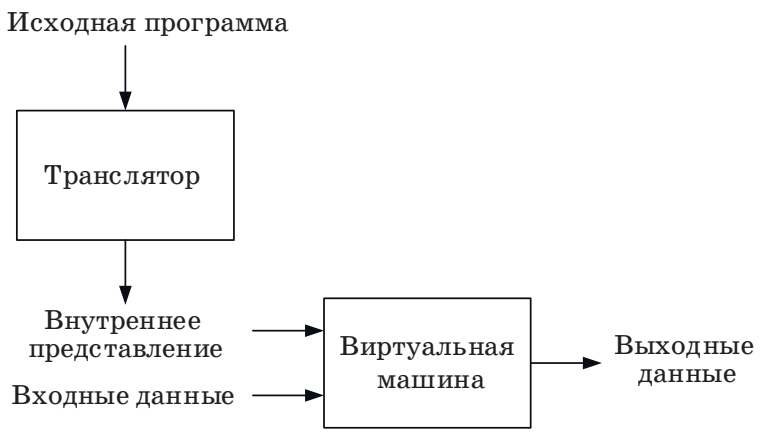

- Puc. 3. Структура гибридного компилятора

- Fig. 3. The hybrid compiler structure 


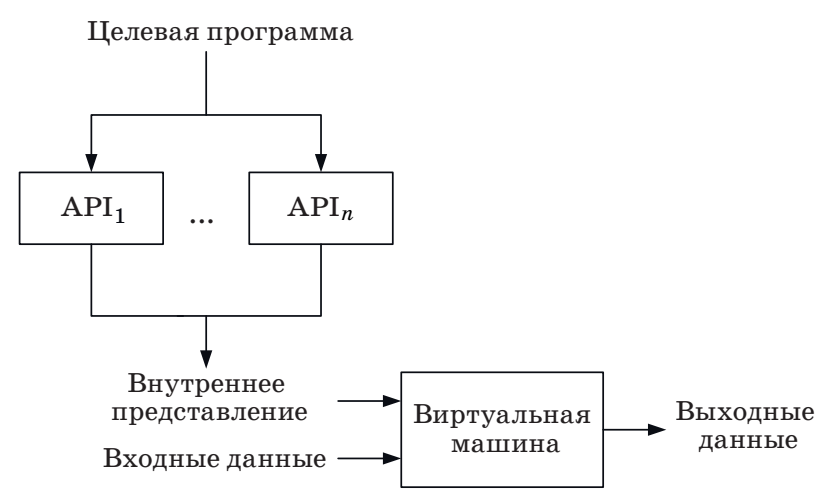

- Puc. 4. Формирование байт-кода на управляющей стороне для интерпретации на узле

- Fig. 4. The bytecode generation on the control side for interpretation on the node

и многие другие, используют данный подход. Виртуальные машины используются в основном для платформо-независимого исполнения кода и обеспечивают большую производительность по сравнению с интерпретацией и выполнением непосредственно исходного кода программы $[10,11]$. Такая реализация позволяет строить гетерогенные распределенные сети, включающие узлы на процессорах с различными архитектурами.

Приведенная схема справедлива как для случая, когда инициирующей стороной выступает управляющий узел, так и для случая, когда управляемый узел формирует байт-код для исполнения на виртуальной машине другого узла. Таким образом, можно утверждать, что данный подход организует распределенное объектное взаимодействие посредством распределенной системы виртуальных машин.

\section{Динамическое управление степенью загруженности узлов сети}

В рассматриваемом примере АД, будучи запущенными на одном узле, распространяются по всем доступным узлам для выполнения полезной работы.

В этом случае возможны следующие стратегии распределения исполнимого кода по узлам сети.

1. Исполнимый код в АД сопровождает полезные данные и осуществляет задачу навигации этих полезных данных. Тогда программа АД, запускаясь на узле, производит оценку окружения (доступности последующих узлов, тестирования возможностей аппаратуры) и выбирает направления для следующего шага распространения полезных данных. При этом исполнимый код повторяет путь следования полезных данных, проходя через те же самые узлы.
2. Пересылка исполнимого кода, управляющего аппаратным обеспечением, в том числе пересылка кодеков для подготовки узлов к приему полезных данных. В этом случае исполнимый код должен быть доставлен на тот узел, на который адресован.

3. Выполнение дополнительной работы для задач кодирования/декодирования потока полезных данных, задач принятия решений об управлении физической конфигурацией группировки БЛА и т. п. В таком случае исполнимый код АД должен распространяться по узлам сети по правилам, известным из распределенных вычислительных и, в том числе, многопроцессорных систем. В связи с этим требуется решать задачу динамической балансировки нагрузки на узлы сети путем перераспределения ее алгоритмической составляющей.

Рассмотрим распределенную программно-реконфигурируемую систему, в узлах которой находятся виртуальные машины, как частный случай распределенной многопроцессорной системы.

В данном случае под многопроцессорной системой понимается система, содержащая несколько процессорных элементов, на которых размещаются виртуальные машины, без общей памяти, которые могут обмениваться сообщениями, содержащими АД.

В связи с тем, что для выполнения исполнимого кода АД используются виртуальные машины, можно считать рассматриваемую многопроцессорную систему гомогенной даже при гетерогенной структуре узлов (используются разнородные процессоры и различная физическая природа узлов: стационарные, мобильные, летающие).

Традиционно в системах виртуализации за распределение ресурсов между физическими хостами отвечает гипервизор (hypervisor), используя алгоритмы балансировки нагрузки [12-15].

Существуют два основных подхода в балансировке нагрузки, которые можно обозначить как выталкивающие миграции и притягивающие миграции. Выталкивающие миграции - перенос полезной нагрузки на наименее нагруженный узел с более нагруженного. При использовании подхода с притягивающими миграциями нагрузка переносится на узел, когда этот узел начинает простаивать [16].

Управление ресурсами в рамках распределенной системы виртуальных машин представляет собой итерационный процесс, состоящий из следующих этапов (рис. 5).

1. Гипервизор (менеджер ресурсов) собирает статистические данные об используемых ресурсах за определенный временной интервал. На основе предварительной обработки принимается решение о запуске перераспределения ресурсов в случае нарушения предварительно заданных условий.

2. На этапе планирования миграций менеджер ресурсов на основании конкретного алго- 


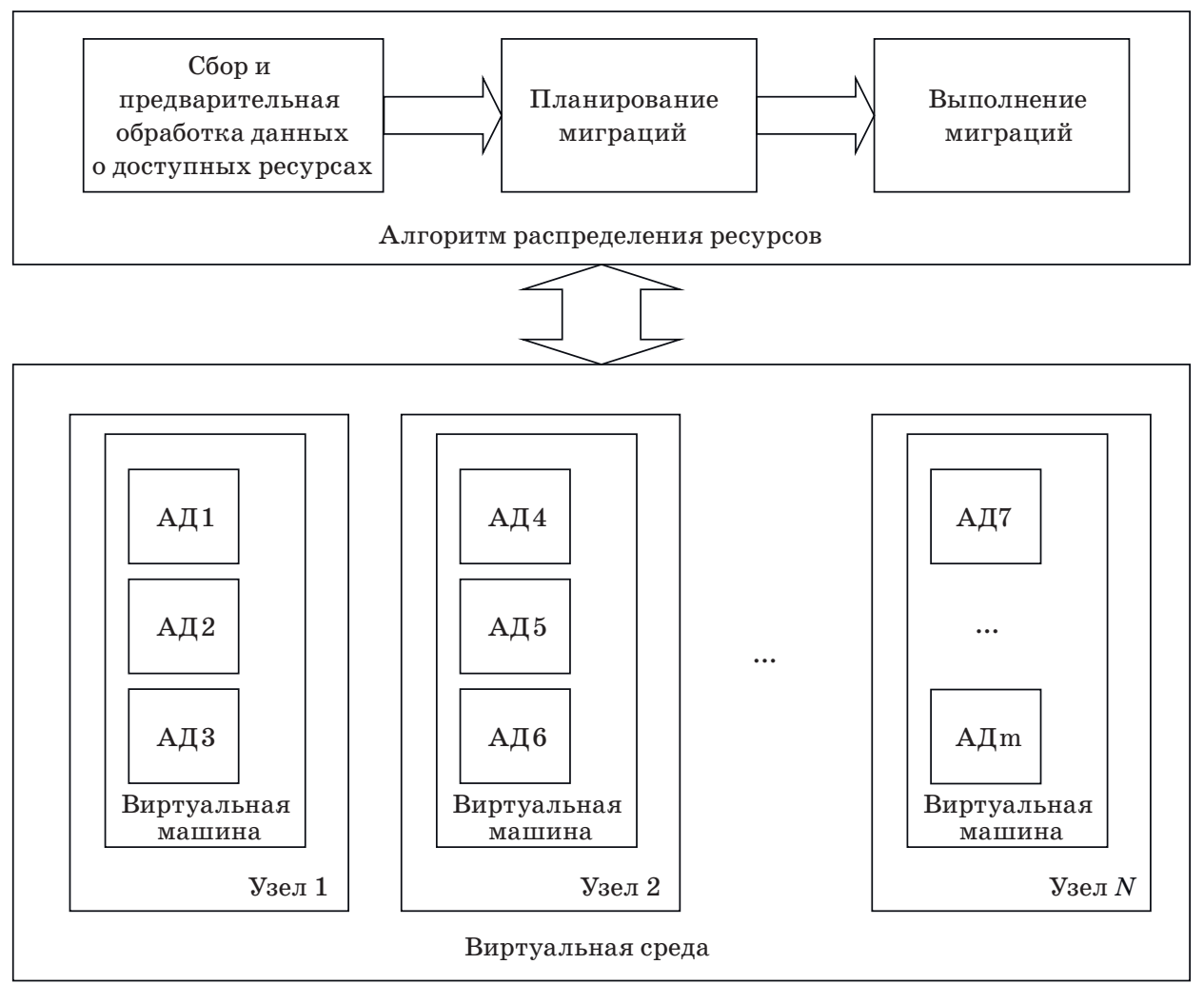

- Puc. 5. Архитектура менеджера ресурсов

- Fig. 5. The resource manager architecture

ритма балансировки формирует план миграции, который должен устранить или минимизировать возникшие нарушения условий.

3. Выполняется перераспределение алгоритмической составляющей между узлами путем передачи АД между узлами согласно плану миграции.

Основным отличием балансировки нагрузки в распределенной системе виртуальных машин от подходов к балансировке в облачных сервисах или механизмов RPC (Remote Procedure Call) можно считать, в частности, асинхронность процессов, а также отсутствие необходимости сериализации объектов.

Рассмотрим существующие алгоритмы балансировки нагрузки, используемые в виртуализации.

Разлещение виртуальных машин с учетол трафика. В работе [17] предлагается рассматривать задачу балансировки как частный случай задачи о многомерном рюкзаке. В качестве измерений рюкзака выбраны оперативная память, процессорное время и ресурс межпроцессорной шины, используемые виртуальной машиной. Предложенный подход использует алгоритм «первый подходящий» для первичного размещения виртуальных машин на физической машине, а дальше на каждом шаге проверяется сбалансированность потребления процессорного времени.
Взвешенная рандомизированная миграция. Подход, описанный в статье [18], предлагает для каждой виртуальной машины находить наиболее подходящий узел, основываясь на штрафе за использование межпроцессорной шины. Исследования проводились на базе платформы визуализации Xen. Критерии штрафа опираются на значения, вычисляемые по счетчикам производительности процессора.

Циклический алгоритл Round Robin, или алгоритм кругового обслуживания, работает по принципу кругового цикла, или «карусели», запросы передаются по очереди каждому следующему серверу соответственно, а при достижении последнего сервера при следующем запросе производится обращение снова к первому. Более подробно данный алгоритм описан в работе [19].

Взвешенный ииклический алгоритм [20] усовершенствованная версия алгоритма Round Robin, отличается тем, что серверам ставятся в соответствие весовые коэффициенты, их значение определяется производительностью сервера.

Основная цель использования перечисленных алгоритмов состоит в перемещении объектов между виртуальными машинами с перераспределением нагрузки с перегруженных узлов, а также в обеспечении возможности динамически консолидировать объекты на наименьшем числе 
узлов, чтобы обеспечивать энергоэффективность узлов при низкой загрузке [21].

Тем не менее непрерывная миграция имеет достаточно высокую цену, обоснованную потерей производительности виртуальных машин в процессе миграции, и соответствующее увеличение энергозатрат.

Для каждого узла в составе гипервизора добавлен менеджер ресурсов, который получает решения о распределении ресурсов виртуальных машин других узлов. Каждый менеджер ресурсов участвует в динамическом определении общих ресурсов, предназначенных для распределения на его виртуальной машине, и соответственно принимает решение о распределении. Отличительной особенностью менеджера ресурсов является дискретный принцип его работы: решения о распределении ресурсов принимаются в дискретные промежутки времени на следующий дискретный временной промежуток.

\section{Заключение}

В статье рассматривается развитие подхода АД для реализации динамической программноопределяемой системы на примере группировки БЛА-ретрансляторов.

Сложившееся на текущий момент времени противоречие в тенденциях создания автономных инфокоммуникационных систем требует разработки новых теоретических подходов и архитектурных решений. С одной стороны, в соответствии с современными тенденциями развития технологий программирования требуется четкое разделение на исполнимый код и код, защищенный от исполнения. С другой стороны, сама концепция построения программно-определяемых систем требует максимальной однородности исполняемого кода и данных. В качестве пути устранения такого противоречия предлагается использовать виртуальные машины, обладающие тьюринг-полнотой, но с ограниченными функциональными возможностями (режим «песочницы»), на которых выполняется исполнимый код АД.

\section{Литература}

1. Кулешов С. В., Зайцева А. А., Аксенов А. Ю. Развитие информационных технологий: программируемое и непрограммируемое. Инфорлатизация $и$ связь, 2017, № 3, с. 34-39.

2. Кулешов С. В., Цветков О. В. Активные данные в цифровых программно-определяемых системах. Информационно-измерительные и управляющие системы, 2014, № 6, с. 12-19.
Объединение отдельных виртуальных машин на узлах позволяет рассматривать их совокупность как распределенную систему виртуальных машин, с асимметричным распределением алгоритмической составляющей по узлам, построенную на принципах объектно-ориентированной парадигмы и ориентированную на исполнение байт-кода.

Особенностями такой архитектуры являются:

- динамическое управление объектами на управляемых узлах, дающее возможность удаленного реконфигурирования узла с реализацией концепции программно-управляемого подхода;

- использование объектно-ориентированной парадигмы для взаимодействия объектов в распределенной системе, что позволяет строить объектное взаимодействие в привычной для программистов форме;

- возможность управления величиной асимметричности путем создания объектов различного уровня декомпозиции и как следствие возможность регулирования энергопотребления узла и количества передаваемых сетевых данных.

Для случаев решения задач (кейсов), допускающих распараллеливание на сеть узлов, рассмотрены варианты применения балансировки нагрузки между узлами для получения наибольшей эффективности работы всей системы.

Предлагаемый подход является альтернативным решением построения самоорганизующихся сетей, основанным на агрегации принципов работы облачных сервисов и программно-определяемых систем, реализованных через выполнение программного кода АД на узлах сети.

Дальнейшие исследования предполагают экспериментальную отработку взаимодействия виртуальных машин для наиболее востребованных вариантов применения АД.

\section{Финансовая поддержка}

Работа выполнена в рамках реализации Государственного задания на 2019 г. № 0073-20190005 . 
Workshop: Developing Strategies to Meet the Cyber Security and Information Intelligence Challenges Ahead, 2008. doi:10.1145/1413140.1413167

5. Stakem P. H. Computer Architecture \& Programming of the Intel $x 86$ Family. 2013. 173 p.

6. Data Execution Prevention - Technical Manual by Hewlett-Packard Development Company. http:// www1.hp.com/ctg/Manual/c00387685 (дата обращения: 12.03.2019).

7. Шальнев И. О. Подход к построению распределенных систем на основе балансировки объема исполняемого кода между узлами. Технологическая перспектива в ралках Евразийского пространства: новые рынки и точки эконолического роста: мате риалы 4-й Международной научной конферениии, Санкт-Петербург, 13-15 декабря 2018 г., СПб., Астерион, 2018, с. 165-172.

8. Kuleshov S. V., Zaytseva A., Aksenov A. Y. The conceptual view of unmanned aerial vehicle implementation as a mobile communication node of active data transmission network. International Journal of Intelligent Unmanned Systems, 2018, vol. 6, iss. 4, pp. 174-183. doi:10.1108/IJIUS-04-2018-0010

9. Aho A. V., Lam M. S., Sethi R., Ulman J. D. Compilers. Principles, Techniques, \& Tools. Second Ed. Addison Wesley, 2007. 1038 p.

10. Craig Iain D. Virtual Machines. Springer-Verlag London, 2006. 269 p. doi:10.1007/978-1-84628-246-1

11. Shi Y., Gregg D., Beatty A., Ertl M. A. Virtual Machine Showdown: Stack Versus Registers. https:// www.usenix.org/legacy/events/vee05/full_papers/ p153-yunhe.pdf (дата обращения: 11.03.2019).

12. Abeni L., Biondi A., Bini E. Hierarchical scheduling of real-time tasks over Linux-based virtual machines. Journal of Systems and Software, 2019, vol. 149, pp. 234-249.

13. Diener M., Cruz E. H. M., Navaux P. O. A. Locality vs Balance: Exploring data mapping policies on NUMA systems. 23rd Euromicro International Conference on Parallel, Distributed and Network-Based Processing (PDP), Turku, Finland, 2015, vol. 1, pp. 9-16. doi:10.1109/PDP.2015.11
14. Хританков А. С. Об однол алгоритле балансировки вычислительной нагрузки в распределенных систелах. http://www.ict.edu.ru/vconf/files/11951. pdf (дата обращения: 11.03.2019).

15. Балансировка нагрузки в распределенных систелах. http://masters.donntu.org/2012/fknt/volokhova/library/article3.htm (дата обращения: 12.03.2019).

16. Polenov M., Guzik V., Lukyanov V. Hypervisors comparison and their performance testing. In: Advances in Intelligent Systems and Computing, Springer, Cham, 2019, vol. 763, pp. 148-157. doi:https://doi. org/10.1007/978-3-319-91186-1_16

17. Cheng Y., Chen W., Wang Z., Yu X. Performance-monitoring-based traffic-aware virtual machine deployment on NUMA systems. IEEE Systems Journal, 2017, vol. 11, no. 2, pp. 973-982. doi:10.1109/JSYST. 2015.2469652

18. Rao J., Wang K., Zhou X., Xu C. Optimizing virtual machine scheduling in NUMA multicore systems. 2013 IEEE 19th International Symposium on High Performance Computer Architecture (HPCA), Shenzhen, 2013, pp. 306-317. doi:10.1109/HPCA.2013. 6522328

19. Aymaz Ş., Çavdar T., Aymaz S., Öztürk E. An analysis of load balancing strategies with wireshark in software defined networks. 2018 International Conference on Artificial Intelligence and Data Processing (IDAP), Malatya, Turkey, 2018, pp. 1-5. doi:10.1109/ IDAP.2018.8620766 19

20. Liu G., Wang X. A modified Round-Robin load balancing algorithm based on content of request. 2018 5th International Conference on Information Science and Control Engineering (ICISCE), Zhengzhou, 2018, pp. 66-72. doi:10.1109/ICISCE.2018.00023

21. Minarolli D., Mazrekaj A., Freisleben B. Tackling uncertainty in long-term predictions for host overload and underload detection in cloud computing. Journal of Cloud Computing, 2017, vol. 6:4, no. 1. https://link.springer.com/content/pdf/10.1186\%2Fs 13677-017-0074-3.pdf (дата обращения: 13.03.2019).

UDC 007.52:621.39

doi:10.31799/1684-8853-2019-5-30-37

Distributed system of virtual machines for self-organized networks

S. V. Kuleshov a, Dr. Sc., Tech., Principal Researcher, orcid.org/0000-0002-8454-5598

A. A. Zaytseva ${ }^{a}$, PhD, Tech., Senior Researcher, orcid.org/0000-0002-1345-8550, vaz1976@mail.ru

I. O. Shalneva, Post-Graduate Student, orcid.org/0000-0001-9383-1089

aSaint-Petersburg Institute for Informatics and Automation of the RAS, 39, 14 Line, V. O., 199178, Saint-Petersburg,

Russian Federation

Introduction: Active data, being fragments of executable code transmitted between the nodes of an active network, are an effective mechanism for the operation of software-reconfigurable distributed systems. Previously, in the works devoted to active data, not enough attention was paid to the implementation of the runtime environment (the processor) for the executable code of active data, as well as to the issues of building hypervisors and load balancing in distributed systems. Purpose: Developing principles for the construction of 
virtual machines with active data, providing the reconfigurability of the target devices and network flexibility in general. Evaluating the possibility of using the existing approaches to load balancing for networks with active data. Methods: Our study uses the principles of software-defined system development, the conception of active data, theoretical foundations and technology of virtualization. Results: Is has been proposed to use a distributed system of virtual machines as an active data execution environment, based on the object-oriented approach to creating distributed applications. Each node of such a distributed system of virtual machines can act as either a control or slave node during the object interaction. Based on the developed approach, we proposed to solve the problem of building a network of repeaters using active data, considering an unmanned aerial vehicle as an element of an active info-communication network which supports the active data technology. Since a distributed system of virtual machines enables asymmetric distribution of decentralized network nodes, a method has been developed for a distributed system whose nodes are unmanned aerial vehicles and a control node, to control the asymmetry value by creating objects of various decomposition levels. Practical relevance: The proposed methods provide a way to control the resource consumption of the nodes of a distributed software-reconfigurable network and the amount of network data transmitted. For dynamic management of the load on the network nodes, a resource manager architecture and a resource allocation algorithm are developed.

Keywords - active data, virtual machine, distributed network, unmanned aerial vehicle, data transmission, software-defined systems, self-organized networks.

For citation: Kuleshov S. V., Zaytseva A. A., Shalnev I. O. Distributed system of virtual machines for self-organized networks. Informatsionno-upravliaiushchie sistemy [Information and Control Systems], 2019, no. 5, pp. 30-37 (In Russian). doi:10.31799/16848853-2019-5-30-37

\section{References}

1. Kuleshov S. V., Zaytseva A. A., Aksenov A. Y. Data processing technologies: programming and non-programming. Informatization and Communication, 2017 , no. 3 , pp. 34-39 (In Russian).

2. Kuleshov S. V., Tsvetkov O. V. Active data in digital software-defined systems. Informatsionno-izmeritelnye i uprav lyayushchie sistemy, 2014, no. 6, pp. 12-19 (In Russian).

3. Alexandrov V. V., Kuleshov S. V., Zaytseva A. A. Active Data in Digital Software Defined Systems Based on SEMS Structures. In: Smart Electromechanical Systems. Ed. A. Gorodetskiy. Studies in Systems, Decision and Control, Springer, Cham, 2016, vol. 49, pp. 61-69.

4. Sharp B. L., Peterson G. D., Lok K. Y. Extending hardware based mandatory access controls for memory to multicore architectures. Proc. of 4th Annual Cyber Security and Infor mation Intelligence Research Workshop: Developing Strate gies to Meet the Cyber Security and Information Intelligence Challenges Ahead, 2008. doi:10.1145/1413140.1413167

5. Stakem P. H. Computer Architecture \& Programming of the Intel x86 Family. 2013. 173 p.

6. Data Execution Prevention - Technical Manual by Hewl ett-Packard Development Company. Available at: http:// www1.hp.com/ctg/Manual/c00387685 (accessed 12 March 2019).

7. Shalnev I. O. Building distributed systems approach based on balancing of a source code capacity between network nodes. Materialy 4-y Mezhdunarodnoy nauchnoy konferent sii "Tekhnologicheskaya perspektiva $v$ ramkakh Yevraziys kogo prostranstva: novyye rynki i tochki ekonomicheskogo rosta" [Materials of the 4th International Scientific Conference "Technological perspective in the framework of the Eurasian space: new markets and points of economic growth"], Sint-Petersburg, 2018, pp. 165-172 (In Russian).

8. Kuleshov S. V., Zaytseva A., Aksenov A. Y. The conceptual view of unmanned aerial vehicle implementation as a mobile communication node of active data transmission network. International Journal of Intelligent Unmanned Sys tems, 2018, vol. 6, iss. 4, pp. 174-183. doi:10.1108/IJIUS-04-2018-0010

9. Aho A. V., Lam M. S., Sethi R., Ulman J. D. Compilers. Prin ciples, Techniques, \& Tools. Second Ed. Addison Wesley, 2007. $1038 \mathrm{p}$.

10. Craig Iain D. Virtual Machines. Springer-Verlag London, 2006. 269 p. doi:10.1007/978-1-84628-246-1

11. Shi Y., Gregg D., Beatty A., Ertl M. A. Virtual Machine Showdown: Stack Versus Registers. Available at: https:// www.usenix.org/legacy/events/vee05/full_papers/ p153-yunhe.pdf (accessed 11 March 2019).
12. Abeni L., Biondi A., Bini E. Hierarchical scheduling of real-time tasks over Linux-based virtual machines. Journal of Systems and Software, 2019, vol. 149, pp. 234-249.

13. Diener M., Cruz E. H. M., Navaux P. O. A. Locality vs balance: Exploring data mapping policies on NUMA systems. 23rd Euromicro International Conference on Parallel, Dis tributed and Network-Based Processing (PDP), Turku, Finland, 2015, vol. 1, pp. 9-16. doi:10.1109/PDP.2015.11

14. Khritankov A. S. Ob odnom algoritme balansirovki vychisli tel'noy nagruzki $v$ raspredelennykh sistemakh [On one algorithm for balancing the computational load in distributed systems]. Available at: http://www.ict.edu.ru/vconf/ files/11951.pdf (accessed 11 March 2019).

15. Balansirovka nagruzki v raspredelennykh sistemakh $[\mathrm{Load}$ balancing in distributed systems]. Available at: http://masters.donntu.org/2012/fknt/volokhova/library/article3. htm (accessed 12 March 2019).

16. Polenov M., Guzik V., Lukyanov V. Hypervisors comparison and their performance testing. In: Advances in Intelligent Systems and Computing. Springer, Cham, 2019, vol. 763, pp. 148-157. doi:https://doi.org/10.1007/978-3-319-911861 16

17. Cheng Y., Chen W., Wang Z., Yu X. Performance-monitoring-based traffic-aware virtual machine deployment on NUMA systems. IEEE Systems Journal, 2017, vol. 11, no. 2 , pp. 973-982. doi:10.1109/JSYST.2015.2469652

18. Rao J., Wang K., Zhou X., Xu C. Optimizing virtual machine scheduling in NUMA multicore systems. 2013 IEEE 19th International Symposium on High Performance Computer Architecture (HPCA), Shenzhen, 2013, pp. 306-317. doi:10.1109/HPCA.2013.6522328

19. Aymaz Ş., Çavdar T., Aymaz S., Öztürk E. An analysis of load balancing strategies with wireshark in software defined networks. 2018 International Conference on Artificial Intelligence and Data Processing (IDAP), Malatya, Turkey, 2018, pp. 1-5. doi:10.1109/IDAP.2018.8620766 19

20. Liu G., Wang X. A Modified Round-Robin load balancing algorithm based on content of request. 20185 th International Conference on Information Science and Control Engineering (ICISCE), Zhengzhou, 2018, pp. 66-72. doi:10.1109/ ICISCE.2018.00023

21. Minarolli D., Mazrekaj A., Freisleben B. Tackling uncertainty in long-term predictions for host overload and underload detection in cloud computing. Journal of Cloud Computing, 2017, vol. 6:4, no. 1. Available at: https://link. springer.com/content/pdf/10.1186\% 2Fs13677-017-0074-3. pdf (accessed 13 March 2019). doi:10.1186/s13677-0170074-3 


\title{
Исследование моделей связности сенсорных сетей
}

\author{
T. Н. Астаховаа, канд. физ.-мат. наук, доцент, orcid.org/0000-0002-7032-0697, ctn_af@mail.ru \\ Н. А. Верзунб, в, канд. техн. наук, доцент, orcid.org/0000-0002-0126-2358 \\ B. В. Касаткинг, канд. техн. наук, доцент, orcid.org/ 0000-0001-7523-4926 \\ М. О. Колбаневб, в, доктор техн. наук, профессор, orcid.org/0000-0003-4825-6972 \\ А. А. Шамина, канд. экон. наук, доцент, orcid.org/0000-0001-7690-8718 \\ анижегородский государственный инженерно-экономический университет, Октябрьская ул., 20а, \\ Княгинино, 606340, РФ

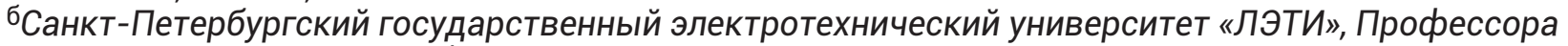 \\ Попова ул., 5, Санкт-Петербург, 197376, РФ \\ в Санкт-Петербургский государственный экономический университет, Садовая ул., 21, \\ Санкт-Петербург, 191023, РФ \\ гСанкт-Петербургский институт информатики и автоматизации РАН, 14-я линия В. О., 39, \\ Санкт-Петербург, 199178, РФ
}

Введение: одним из ключевых и актуальных направлений исследований беспроводных сенсорных сетей является изучение способов экономии энергии отдельными устройствами для увеличения времени их функционирования без перезаряда батареи. В настоящей статье вводится и исследуется новая, учитывающая энергопотребление, стохастическая характеристика качества функционирования беспроводной сенсорной сети, расширяющая понятие связности. Эта характеристика отражает способность сети устанавливать соединения между сетевыми элементами в пределах геометрических границ сенсорного поля в реальном масштабе времени при определенном уровне заряда батарей сенсорных устройств. Цель исследования: выявление взаимной зависимости вероятностно-временных и вероятностноэнергетических характеристик, а также влияния на эти характеристики таких параметров беспроводной сенсорной сети, как геометрические размеры, модель распределения сенсорных устройств в пределах сенсорного поля, топология сети и алгоритмы маршрутизации сообщений. Результаты: предложена новая стохастическая характеристика качества функционирования беспроводных сенсорных сетей - связность, которая охватывает в комплексе пространственные, временные и энергетические характеристики сети, что позволяет с общих позиций описать широкий комплекс задач, возникающих при исследовании процессов функционирования беспроводных сетей на этапах сбора, распространения и обработки данных сенсорными устройствами; введены стохастические показатели связности беспроводных сенсорных сетей, которые описывают сеть как целое, что позволяет исследовать процессы задержки и блокировки информационного обмена с учетом размера сенсорного поля и мощности, потребляемой отдельными устройствами; построены модели для оценки вероятности связности беспроводных сенсорных сетей, времени доставки сообщений и квантиля времени доставки, что позволяет повысить точность оценок качества функционирования беспроводной сенсорной сети. Практическая значимость: полученные модели и методы нацелены на использование при цифровизации сельскохозяйственных организаций и в учебном процессе Княгининского университета.

Ключевые слова - беспроводная сенсорная сеть, вероятностно-временные характеристики, вероятностно-энергетические характеристики, вероятность связности, время доставки сообщений, кластер, мощность сигнала на передающей антенне, связность сети, $\mu$-квантиль времени доставки.

Для цитирования: Астахова Т. Н., Верзун Н. А., Касаткин В. В., Колбанев М. О., Шамин А. А. Исследование моделей связности сенсорных сетей. Информационно-управляющие систелы, 2019, № 5, с. 38-50. doi:10.31799/1684-8853-2019-5-38-50

For citation: Astakhova T. N., Verzun N. A., Kasatkin V. V., Kolbanev M. O., Shamin A. A. Sensor network connectivity models. Informatsionno-upravliaiushchie sistemy [Information and Control Systems], 2019, no. 5, pp. 38-50 (In Russian). doi:10.31799/16848853-2019-5-38-50

\section{Введение}

В последнее время широкое распространение интернета вещей и других технологий третьей платформы информатизации [1] привело к появлению большого числа публикаций, посвященных исследованию всепроникающих сенсорных сетей, объединяющих сенсорные устройства, которые контролируют те или иные параметры физического пространства, свободно перемещаются в этом пространстве и имеют автономное питание.
К числу наиболее актуальных направлений исследования беспроводных сенсорных сетей относится изучение способов экономии энергии отдельными устройствами для увеличения времени их функционирования без перезаряда батареи [2-7]. Исследования такого рода имеют и ярко выраженный экологический аспект, поскольку объем энергии, потребляемой инфокоммуникационными системами и сетями, достиг трети от всей электроэнергии, генерируемой в мире, так что сети оказывают все большее негативное влияние на окружающую среду $[8,9]$. 
В настоящей статье вводится и исследуется новая, учитывающая энергопотребление, стохастическая характеристика качества функционирования беспроводной сенсорной сети, расширяющая понятие связности. Она отражает способность сети устанавливать соединения между сетевыми элементами в пределах границ сенсорного поля в реальном масштабе времени при определенном уровне заряда батарей сенсорных устройств.

В фиксированных сетях связи [10], использующих системы с центральной батареей, связность обусловлена топологией сети, т. е. способом соединения сетевых элементов друг с другом. Передача данных между стационарно расположенными терминалами обеспечивается здесь оконечными станциями и транзитными узлами и может быть блокирована только в случае перегрузки сети или отказа ее элементов.

При определении связности беспроводных сенсорных сетей необходимо учитывать не только выбранную топологию, сетевые перегрузки и надежность сетевых элементов, но и емкость электрических батарей каждого из устройств, поскольку к нарушению связности могут привести:

- разрывы соединений в моменты окончания запаса энергии батареи одного из сетевых элементов;

- невозможность установить соединения изза ограниченной мощности сигнала на передающей антенне сенсорного устройства и слишком больших расстояний от него до соседних сетевых элементов.

Остаточная емкость батареи является функцией энергопотребления, а энергопотребление, в свою очередь, зависит и от размеров контролируемого физического пространства, и от закона распределения сенсорных устройств в этом пространстве, и от протоколов функционирования беспроводной сенсорной сети на физическом, канальном и сетевом уровнях эталонной модели взаимодействия открытых систем [11]. Изменяя размеры сенсорного поля, которое охватывает беспроводная сенсорная сеть, проектируя специальные алгоритмы модуляции, множественного доступа и маршрутизации, которые используют сенсорные устройства, можно существенно сократить расход энергии. Это означает, что возможно восстановление связности, частично потерянной в ходе функционирования беспроводной сенсорной сети, не только путем заряда батареи, но и путем сокращения пространственных параметров беспроводной сенсорной сети или изменения протоколов информационного взаимодействия сенсорных устройств.

Связность как характеристика качества функционирования беспроводной сенсорной сети пред- ставляет собой обобщение другой характеристики беспроводной сенсорной сети - времени жизни сети, под которой понимают [12-14] интервал времени с момента запуска сети в эксплуатацию до момента разряда батареи у любого из сетевых устройств с автономным питанием. Время жизни сети можно рассматривать как частный случай связности, когда прерывается информационное взаимодействие с одним из сетевых устройств. Связность сети, в отличие от времени жизни сети, характеризует сеть в целом, а не свойства ее отдельных элементов [15, 16]. Она дает возможность исследовать как процессы задержки и блокировки информационного обмена из-за недостаточной мощности радиопередатчика, так и процессы функционирования сети при восстановлении энергопитания сетевых элементов, временно прекративших свою работу.

Объектом исследования в данной статье является беспроводная сенсорная сеть связи, состоящая из сенсорных узлов, контролирующих физическое пространство, и головного узла, который аккумулирует информацию, поступающую от сенсоров всех устройств. Предметом исследования выступают модели связности беспроводной сенсорной сети, описывающие, с одной стороны, вероятностно-временные характеристики процесса обмена сообщениями и, с другой стороны, вероятностно-энергетические характеристики процесса потребления электроэнергии, обеспечивающего такой обмен в физическом пространстве.

Цель исследования - выявление взаимной зависимости вероятностно-временных и вероятностно-энергетических характеристик, а также влияния на эти характеристики таких параметров беспроводной сенсорной сети, как ее геометрические размеры, модель распределения сенсорных устройств в пределах сенсорного поля, топология беспроводной сенсорной сети и алгоритмы маршрутизации сообщений.

Показателями связности беспроводной сенсорной сети выбраны следующие вероятностновременные характеристики процесса информационного взаимодействия сенсорных устройств друг с другом и с головным узлом, рассчитываемые при заданном уровне энергопотребления устройствами и размерах сенсорного поля:

- вероятность связности сети;

- время доставки сообщений до головного узла кластера беспроводной сенсорной сети;

- $\mu$-квантиль времени доставки сообщений.

Получены функциональные зависимости этих вероятностно-временных характеристик от мощности радиосигнала на передающей антенне сенсорного устройства, используемого частотного диапазона и коэффициентов усиления передающей и приемной антенн. 


\section{Кластерная организация беспроводной сенсорной сети}

Основные электропотребители типичного сенсорного устройства представлены на рис. 1. Помимо собственно сенсорной подсистемы, объединяющей группу аналоговых и (или) цифровых сенсоров для измерения некоторого набора физических параметров окружающей среды, это подсистемы обработки и коммуникации. Подсистема коммуникации всегда строится при помощи модулей радиосвязи, поскольку только так можно обеспечить мобильность устройства.

Каждая из этих трех подсистем сенсорного устройства нуждается в энергии электрической батареи, но главным потребителем оказывается радиопередатчик, которому для передачи одного бита данных требуется примерно в миллион раз больше энергии, чем для обработки одного бита в микроконтроллере [6].

На этом основании задача исследования связности беспроводной сенсорной сети с достаточной степенью точности сводится к оценке той энергии, которую потребляет сенсорное устройство для отправки сообщений внутри заданного пространства в соответствии с протоколами работы беспроводной сенсорной сети.

Рассмотрим беспроводную сенсорную сеть, в которой все сенсорные узлы разделены по какому-либо принципу на группы или кластеры [17, 18]. Принципы разделения устройств на группы могут быть различными: географические координаты, типы сенсоров, уровни энергопотребления, емкости электрических батарей и пр. В каждом кластере одно из сенсорных устройств выполняет роль головного кластерного узла, который агрегирует трафик всех остальных сенсорных устройств кластера и продвигает его дальше к базовой станции. Взаимодействие сенсорных устройств с облаком или с сенсорными устройствами других кластеров реализуется через базовые станции. Наиболее общий случай подобной архитектуры - это беспроводная сенсорная сеть, в которой любое сенсорное устройство кластера может в разные моменты времени выполнять роль головного кластерного узла. В работе [19] отмечается, что кластерная организация сенсорной сети эффективна и масштабируема для функционирования беспроводной сенсорной сети лишь при условии рационального выбора головного узла в конкретный момент времени [20-23]. Оценка надежности систем, предусматривающих перераспределение запросов, объединенных в кластеры, дана в работах [24, 25].

Примером протоколов выбора головного кластерного узла служат протоколы LEACH (LowEnergy Adaptive Clustering Hierarchy), BCDCP (Base-Station Controlled Dynamic Clustering Protocol), которые опираются на выбор устройства с наибольшим уровнем остаточной энергии.

Без потери общности полученных результатов ограничимся рассмотрением процессов передачи данных, собираемых сенсорными устройствами одного кластера. Предположим, что каждое из сенсорных устройств с некоторой периодичностью формирует сообщения и передает их головному узлу кластера. На рис. 2 показаны два возможных варианта передачи данных внутри кластера [13]:

- непосредственная передача предусматривает доставку сообщений от каждого сенсорного устройства напрямую головному узлу без транзитов (рис. $2, a)$;

- транзитная передача допускает использование некоторых сенсорных устройств того же кластера в качестве промежуточных (рис. 2, б).

Узел сенсорной сети может потерять возможность передавать данные головному узлу по многим причинам: внешние воздействия, отказ обо-

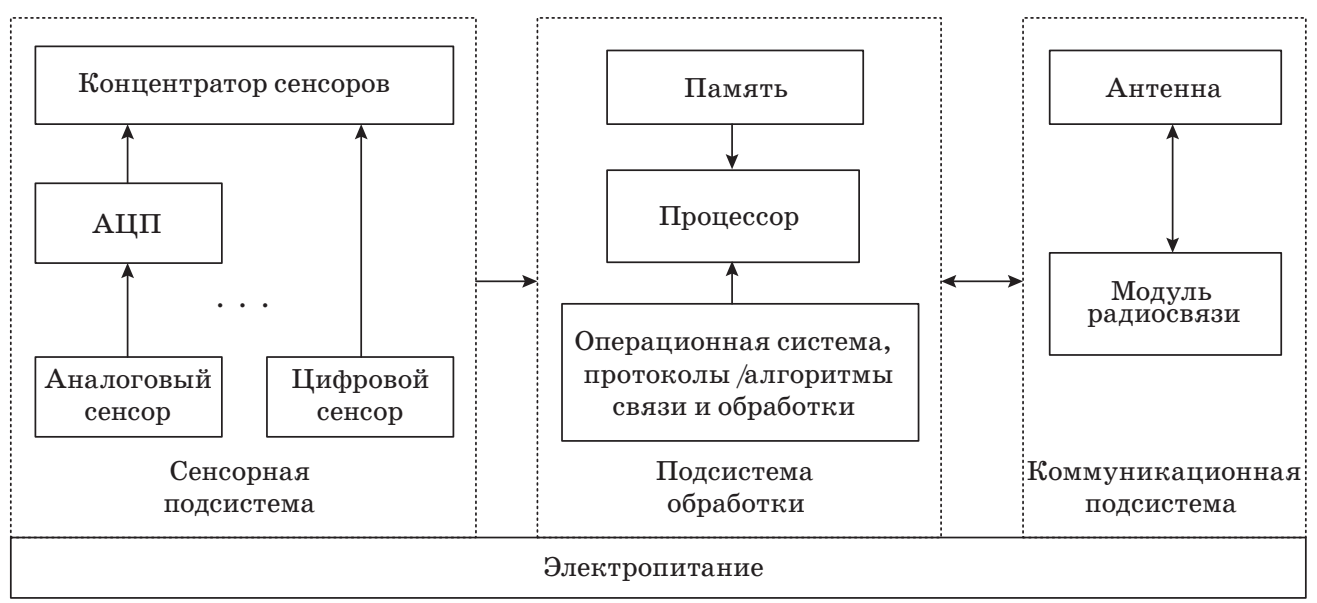

- Puc. 1. Архитектура сенсорного устройства

- Fig. 1. Architecture of sensory unit 
a)

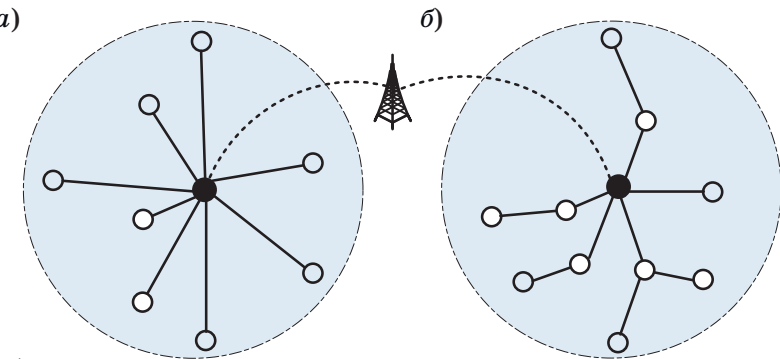

-

- базовая станция

О - сенсорное устройство

Puc. 2. Варианты взаимодействия узлов беспроводной сенсорной сети внутри кластеров: $a$ - одноинтервальная связь; б - многоинтервальная связь

- Fig. 2. Versions of interaction of wireless sensor network nodes within clusters: $a$ - single interval connection; б - multiinterval connection

рудования, сбои в программном обеспечении и др. Рассмотрим одну из возможных причин такого рода - разряд аккумулятора сенсорного узла. Очевидно, что время наступления этого события зависит от начальной емкости батареи и уровня энергопотребления, а энергопотребление, в свою очередь, является случайной величиной, на которую влияют:

- объем передаваемых данных;

- интенсивность взаимодействия устройств;

- используемый радиочастотный спектр;

- геометрический размер кластера;

- плотность расположения сенсорных устройств;

- количество хопов (транзитов) при передаче;

- распределения сенсорных устройств в пространстве;

- используемые протоколы маршрутизации;

- другие параметры и алгоритмы работы беспроводной сенсорной сети и сенсорных устройств.

В рассматриваемой беспроводной сенсорной сети с кластерной организацией сенсорные устройства могут быть мобильными устройствами, а это значит, и число сенсорных устройств в кластере, и координаты их размещения случайны и изменяются с течением времени. Поэтому вероятность того, что какое-либо сенсорное устройство (из-за низкого заряда аккумулятора или удаленности от других устройств) не сможет передать данные головному кластерному узлу в фиксированный момент времени (либо напрямую в случае непосредственной связи, либо через промежуточные сенсорные устройства в случае транзитной связи), может быть отличной от нуля. Это отражает тот факт, что не все попытки передать блок данных от сенсорного головному узлу могут оказаться успешными. Если допустить возможность многократных попыток передачи, осуществляемых че- рез определенные интервалы времени, то время доставки блока данных от сенсорного устройства к головному узлу будет случайной величиной, зависящей не только от фактического расстояния между ними, но и от вероятности связности сенсорного узла с головным кластерным узлом.

\section{Вероятность связности беспроводной сенсорной сети}

Для оценки связности беспроводной сенсорной сети и ее жизнеспособности целесообразно использовать показатели, учитывающие вероятностную и переменную (т. е. изменяющуюся во времени) топологию подобных сетей.

Введем следующие показатели связности беспроводной сенсорной сети:

- вероятность связности сенсорных устройств, $P_{\text {св }}$ - вероятность того, что передача данных от сенсорного узла к головному кластерному узлу возможна. Будем считать беспроводную сенсорную сеть работоспособной (жизнеспособной), если вероятность связности сенсорных устройств больше допустимого значения $P_{\text {св.д }}$, т. е. когда выполняется условие $P_{\text {св }}>P_{\text {св.д; }}$;

- среднее время доставки блока данных от сенсорного устройства до головного кластерного узла, $T[\mathrm{c}]$;

- $\mu$-квантиль случайной величины времени доставки блока данных от сенсорного к головному кластерному узлу, $t_{\mu}-$ значение, которое случайная величина $t$ времени доставки блока данных от сенсорного устройства к головному кластерному узлу не превышает с заданной вероятностью $\mu$.

Дополнительно предположим следующее:

- сенсорные устройства образуют сенсорное поле точек, распределенных на плоскости по закону Пуассона;

- сенсорные узлы собирают данные о какихлибо физических параметрах окружающей их среды и передают их в виде блоков данных с некоторой периодичностью;

- имеется возможность передавать блоки данных от сенсорных устройств либо непосредственно головному узлу, либо через дополнительные транзитные узлы, т. е. способ организации взаимодействия внутри кластера - многоинтервальный (см. рис. 2, б);

- в фиксированный момент времени известны географические координаты головного и каждого сенсорного узла сети. Это позволяет сенсорному устройству вычислить расстояние от себя до головного узла (обозначим через $R[\mathrm{~m}]$ ), а также определить направление передачи для транзита;

- из-за переменной топологии и возможного отсутствия связности между сенсорными узла- 
ми и головным узлом $\left(P_{\mathrm{cв}} \neq 0\right)$ не всегда имеется возможность доставить блок данных до головного узла. Перед успешной попыткой сенсорное устройство может предпринимать бесконечное или ограниченное число попыток передачи блока данных;

- мощность, которую использует сенсорный узел при передаче данных, ограничена величиной $P_{\text {пер}}$.

Передача радиосигнала через различные преграды в городской среде с радиочастотными шумами на дистанции несколько сотен метров может быть такой же трудной, как и обеспечение связи в прямой видимости на дистанции несколько километров. Примеры реалистических прогнозов расстояния рассматриваются на базе двухлучевой модели распространения радиоволн по формуле Фрииса (Harald Friis) [26]. Будем считать, что передача происходит в однородной среде при отсутствии препятствий, отражений, помех и иных факторов, влияющих на распространение и прием сигнала. Согласно уравнению для передачи мощность $P_{\text {пер }}$ с известной степенью приближения можно пересчитать в радиус круга $r$ [м], в пределах которого может быть выбрано сенсорное устройство для транзита блока данных:

$$
r=\frac{\gamma}{4 \pi \sqrt{P_{п р}}} \sqrt{C_{\text {пер }} C_{\text {пр }} P_{\text {пер }}},
$$

где $\gamma$ - длина волны передаваемого радиосигнала, м; $P_{\text {пр }}$ - мощность радиосигнала на принимаемой антенне, Вт, будем считать заданной константой; $P_{\text {пер }}$ - мощность радиосигнала на передающей антенне, Вт; $C_{\text {пер }}-$ коэффициент усиления передающей антенны; $C_{\text {пр }}$ - коэффициент усиления приемной антенны.
Выше мы предположили, что каждое сенсорное устройство знает направление для передачи блока данных к головному узлу. Если дополнительно предположить, что сенсорное устройство расположено в центре круга, то в этом круге можно выделить сектор (обозначим его как $Q$ ), ориентированный в направлении головного кластерного узла (рис. 3). Сенсорные устройства, попавшие в сектор $Q$, можно использовать как транзитные для передачи блока данных к головному кластерному узлу.

Площадь сектора $Q$ вычисляется по формуле $S_{Q}=\frac{1}{2} r^{2} \alpha$, где $\alpha-$ угол сектора, рад; $r$ - радиус круга [определяется из (1)], в пределах которого может вестись продуктивная передача блока данных от сенсорного узла (либо транзитному узлу, либо головному узлу кластера). Вероятность того, что в этом секторе будет обнаружен сенсорный узел (или головной узел кластера), который можно использовать для передачи ему блока данных в случае, когда узлы образуют пуассоновское поле точек, определяется по следующему закону:

$$
F(r)=1-e^{-\frac{1}{2} r^{2} \alpha \lambda},
$$

где $\lambda$ - плотность размещения сенсорных узлов.

Если фактическое расстояние от сенсорного узла до головного кластерного узла равно $R$, то количество транзитов (хопов) при передаче одного блока данных будет не меньше, чем $\left\lceil\frac{R}{r}\right\rceil$. Существует вероятность того, что таких хопов потребуется больше $\left\lceil\frac{R}{r}\right\rceil$. Более того, существу-

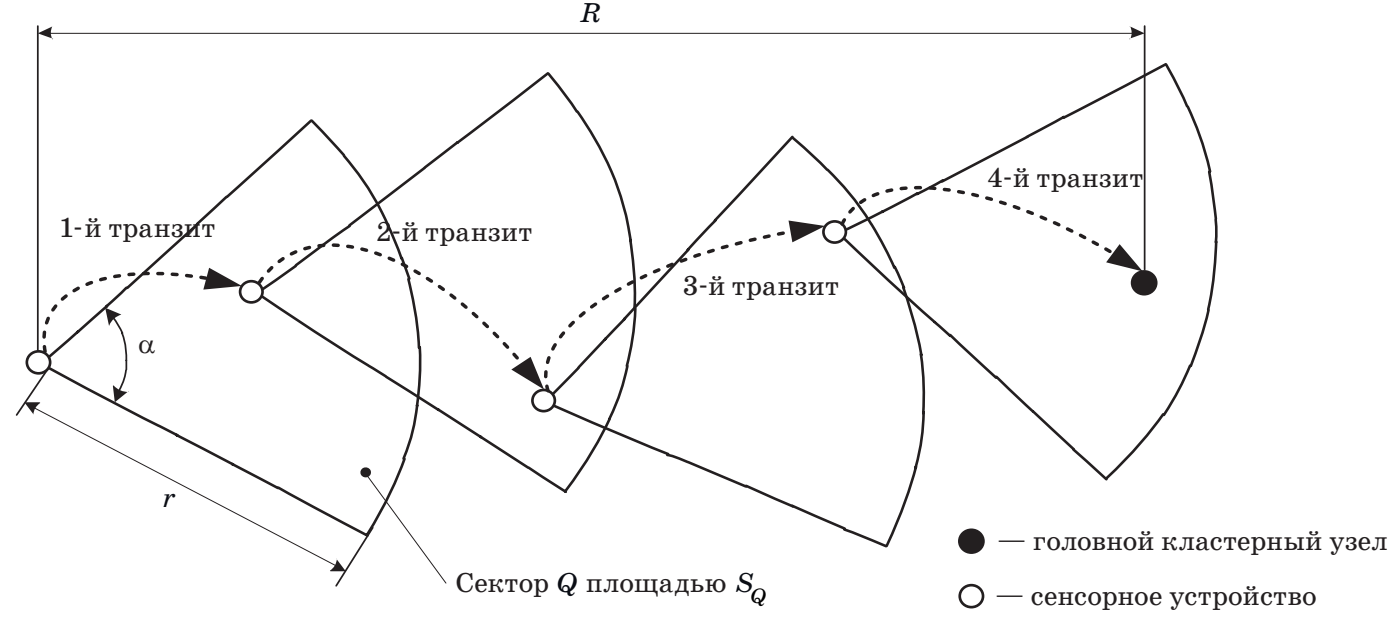

Puc. 3. Передача блока данных от сенсорного устройства к головному кластерному узлу через транзитные сенсорные узлы

- Fig. 3. Transmission a data block from the sensor node to the cluster head via transit sensor nodes 
ет вероятность, что сообщение вообще не будет доставлено из-за того, что в радиусе $r$ в нужном секторе отсутствует сенсорный узел, и поэтому ретрансляция блока данных невозможна, т. е. нарушается связность сенсорных устройств с головным узлом кластера.

Вероятность связности определяется вероятностями нахождения узла в требуемом секторе для осуществления транзита блока данных. Вероятность связности зависит от количества хопов, которые должен преодолеть блок данных. Событие, которое заключается в доставке блока до головного узла, наступит только в том случае, если будут найдены транзитные узлы для каждого хопа. Поэтому для вероятности связности справедлива формула

$$
P_{\mathrm{cB}}=\prod_{i} F_{i}\left(r_{i}\right)=\prod_{i}\left(1-e^{-\frac{1}{2} r_{i}^{2} \alpha \lambda}\right),
$$

где $i-$ номер транзита; $r_{i}-$ расстояние между транзитными узлами на $i$-м хопе.

Доставка блока данных требует некоторых энергетических затрат. Определим их следующим образом.

Плотность функции распределения вероятности того, что при ограниченной мощности сигнала $P_{\text {пер }}$ блок данных будет доставлен от сенсорного к головному узлу кластера, определяется формулой

$$
\begin{gathered}
f_{\xi_{1}+\ldots+\xi_{X}}\left(x_{1}, \ldots, x_{X}\right)= \\
=f_{\xi_{1}}\left(x_{1}\right) * f_{\xi_{2}}\left(x_{2}\right) * \ldots * f_{\xi_{X}}\left(x_{X}\right),
\end{gathered}
$$

где $f_{\xi_{1}}\left(x_{1}\right), f_{\xi_{2}}\left(x_{2}\right), \ldots, f_{\xi_{X}}\left(x_{X}\right)-$ плотности распределений случайных независимых непрерывных величин $\xi_{1}, \ldots, \xi_{X}$ соответственно, а $X-$ количество хопов; «*»- операция свертки [27].

В нашем случае результат свертки имеет смысл случайной величины расстояния, которое проходит блок данных от узла источника к головному узлу. Без потери общности найдем это расстояние для случая двух хопов (т. е. когда $X=2)$.

Вероятность того, что в секторе $Q$ будет обнаружен сенсорный узел (или головной узел кластера), задается формулой (2). Предположим, что расстояние $r$ между двумя сенсорными узлами не больше радиуса действия передающего сенсорного устройства. Тогда из (3) можно написать

$$
f_{\xi_{1}+\xi_{2}}(r)=f_{\xi_{1}}(r) * f_{\xi_{2}}(r)=\int_{0}^{r} f_{\xi_{1}}(u) f_{\xi_{2}}(r-u) \mathrm{d} u,
$$

и случайная величина расстояния, которое преодолевает сообщение от сенсорных устройств, примет вид

$$
\begin{gathered}
f_{\xi_{1}+\xi_{2}}(r)= \\
=\frac{\sqrt{\alpha \lambda}}{4}\left(\operatorname{erf}\left(\frac{1}{2} r \sqrt{\alpha \lambda}\right) \sqrt{\pi}\left(\alpha \lambda r^{2}-2\right)+2 r \sqrt{\alpha \lambda} e^{-\frac{1}{4} \alpha \lambda r^{2}}\right) \times \\
\times e^{-\frac{1}{4} \alpha \lambda r^{2}},
\end{gathered}
$$

где $\operatorname{erf}(x)=\frac{2}{\sqrt{\pi}} \int_{0}^{x} e^{-t^{2}} \mathrm{~d} t-$ функция ошибок.

Вероятность $P_{S}(r)$ того, что расстояние, которое проходит блок данных, не меньше, чем $R$, определяется путем интегрирования функции $f_{\xi_{1}+\xi_{2}}(r):$

$$
\begin{gathered}
P_{S}(r)=F_{\xi_{1}+\xi_{2}}(r)= \\
=-\frac{1}{2}\left(\sqrt{\pi} \operatorname{erf}\left(\frac{1}{2} r \sqrt{\alpha \lambda}\right) r \sqrt{\alpha \lambda} e^{\frac{1}{4} \alpha \lambda r^{2}}-2 e^{\frac{1}{2} \alpha \lambda r^{2}}+2\right) \times \\
\times e^{-\frac{1}{2} \alpha \lambda r^{2}} .
\end{gathered}
$$

Сравнение формул (2) и (4) показывает, что вероятность $P_{S}(r)$ приближается снизу к вероятности $P_{\text {св }}$ по мере увеличения плотности $\lambda$ и может рассматриваться как нижняя граница вероятности связности (рис. 4). В дальнейших расчетах, при оценке вероятности связности, будем использовать формулу (4), поскольку она позволяет сопоставить вероятностно-временные и вероятностно-энергетические характеристики функционирования в плотных и сверхплотных беспроводных сенсорных сетях [28-31].

Подставив расстояние из формулы Фрииса в выражение (4), получим функцию распределения требуемой для этого мощности передатчика

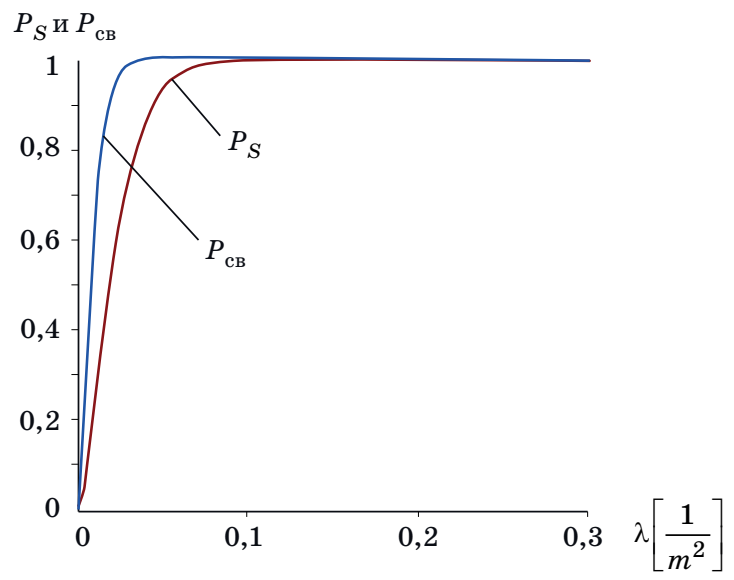

- Puc. 4. Сравнение вероятностей $P_{\text {св }}$ и $P_{S}$

- Fig. 4. Comparison of probabilities $P_{\mathrm{CB}}$ and $P_{S}$ 


$$
\begin{gathered}
P_{S}\left(P_{\text {пер }}\right)=-\frac{1}{2}\left(\operatorname{erf}\left(\frac{1}{2} A \sqrt{\alpha \lambda} \sqrt{P_{\text {пер }}}\right) \sqrt{\pi} \times\right. \\
\left.\times \sqrt{\alpha \lambda} e^{\frac{1}{4} A^{2} P_{\text {пер }} \alpha \lambda} A \sqrt{P_{\text {пер }}}-2 e^{\frac{1}{2} A^{2} P_{\text {пер }} \alpha \lambda}+2\right) \times \\
\times e^{-\frac{1}{2} A^{2} P_{\text {пер }} \alpha \lambda}
\end{gathered}
$$

где $A=\frac{\gamma}{4 \pi \sqrt{P_{\text {пр }}}} \sqrt{C_{\text {пер }} C_{\text {пр }}}$.

Определим далее время доставки блока данных от сенсорного до головного кластерного узла с учетом того, что связность сенсорных устройств - случайная величина.

Время доставки блока данных от сенсорного узла до головного кластерного узла - случайная дискретная величина $T$, складывающаяся, при условии, что $P_{\text {св }} \neq 0$, из нескольких $t$. В рамках данной модели за время $t$ принимается интервал времени между попытками доставки. Для передачи блоков данных от сенсорного устройства выше предположили режим с бесконечным числом попыток, т. е. перед успешной передачей блока данных возможно несколько $(0,1,2, \ldots, \infty)$ неудачных попыток, длительность каждой из которых равна $t$. Под неудачей будем понимать несостоявшуюся попытку передачи блока по причине отсутствия связности сенсора с головным кластерным узлом.

Среднее время доставки блока данных от сенсорного до головного кластерного узла определяется из следующего соотношения:

$$
T=\frac{t\left(1-P_{S}\left(P_{\text {пер }}\right)\right)}{P_{S}\left(P_{\text {пер }}\right)},
$$

или в явном виде

$$
\begin{gathered}
e^{\frac{1}{4} A^{2} P_{\text {пер }} \alpha \lambda}\left(\begin{array}{l}
\sqrt{\pi} \operatorname{erf}\left(\frac{1}{2} A \sqrt{\alpha \lambda} \sqrt{P_{\text {пер }}}\right) \times \\
\left.\times A \sqrt{\alpha \lambda} \sqrt{P_{\text {пер }}}+2 e^{-\frac{1}{4} A^{2} P_{\text {пер }} \alpha \lambda}\right) \\
e^{\frac{1}{4} A^{2} P_{\text {пер }} \alpha \lambda} \sqrt{\pi} \operatorname{erf}\left(\frac{1}{2} A \sqrt{\alpha \lambda} \sqrt{P_{\text {пер }}}\right) \times \\
\times A \sqrt{\alpha \lambda} \sqrt{P_{\text {пер }}}-2 e^{\frac{1}{2} A^{2} P_{\text {пер }} \alpha \lambda}+2
\end{array} .\right.
\end{gathered}
$$

Вероятность того, что сообщение будет доставлено за $N$ попыток, имеет вид

$$
P_{T}\left(P_{\text {пер }}\right)=1-\left(1-P_{S}\left(P_{\text {пер }}\right)\right)^{N} \text {. }
$$

Показатель связности $\mu$-квантиль случайной величины времени доставки блока данных от сенсорного устройства к головному кластерному узлу, $t_{\mu}$ - это значение, которое случайная величина $t$ времени доставки блока данных от сенсорного узла к головному кластерному узлу не превышает с заданной вероятностью $\mu ; t_{\mu}$ определяется как решение уравнения вида

$$
P_{T}\left(P_{\text {пер }}\right)=\mu \text { или } 1-\left(1-P_{S}\left(P_{\text {пер }}\right)\right)^{N}=\mu .
$$

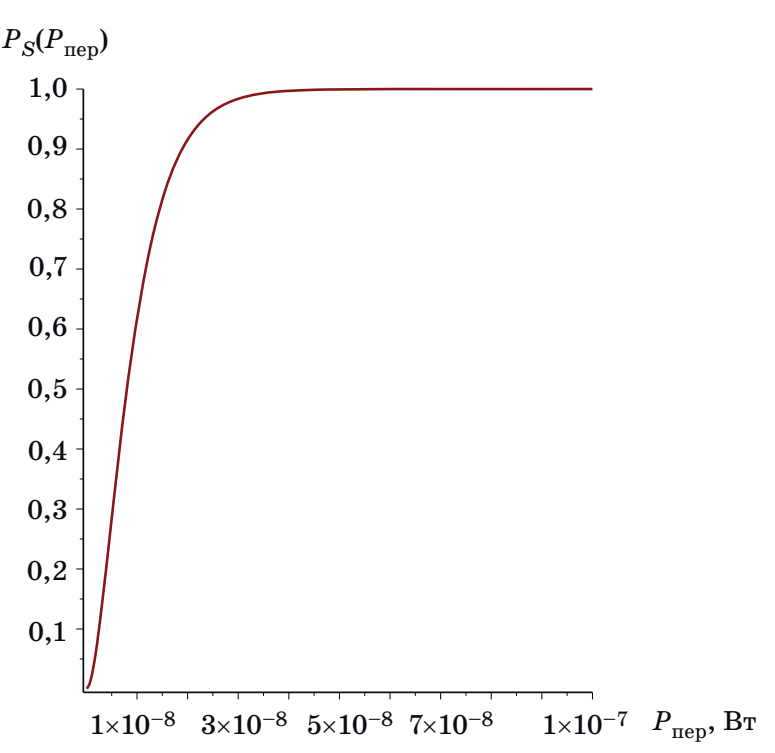

- Puc. 5. Зависимость вероятности связности сенсорных узлов $P_{S}$ от мощности радиопередатчика $P_{\text {пер }}$

- Fig. 5. The dependence of the connectivity probability of the sensor nodes $P_{S}$ on the radio transmitter power $P_{\text {пер }}$

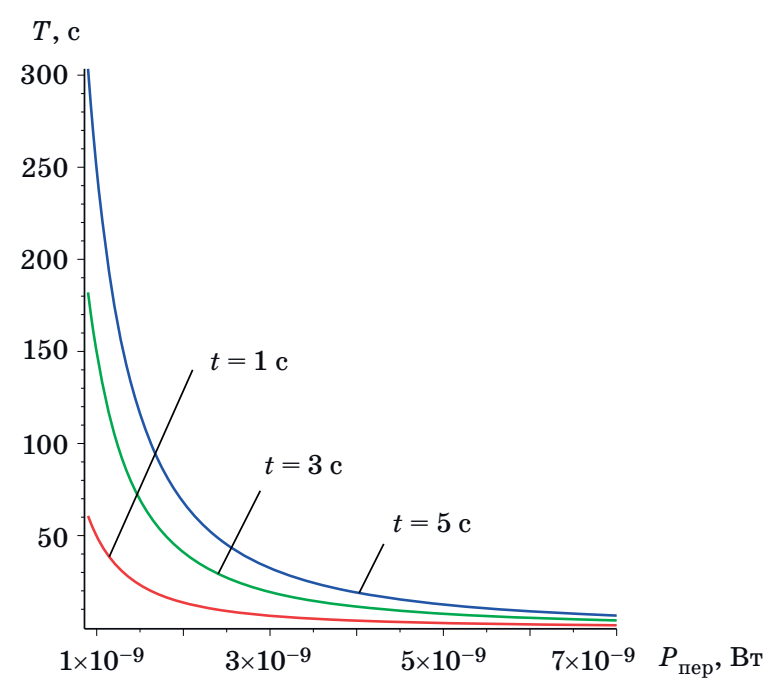

Puc. 6. Зависимость среднего времени доставки от мощности радиопередатчика $P_{\text {пер }}$ при фиксированHOM $t$

- Fig. 6. The dependence of the average delivery time on the radio transmitter power $P_{\text {пер }}$ with fixed $t$ 
Для рассматриваемой модели предполагается, что среднее количество попыток вычисляется следующим образом:

$$
\begin{aligned}
N_{\text {ср }}=\frac{1}{P_{S}\left(P_{\text {пер }}\right)}(1- & \left.\left(1-P_{S}\left(P_{\text {пер }}\right)\right)^{N}\left(N P_{S}\left(P_{\text {пер }}\right)+1\right)\right)+ \\
& +N P_{S}\left(P_{\text {пер }}\right) .
\end{aligned}
$$

Применяя вышеприведенные выражения, проведем численный расчет и анализ влияния мощности радиопередатчика сенсорного устройства на вероятность связности беспроводной сенсорной сети. Расчеты проводились при сле-

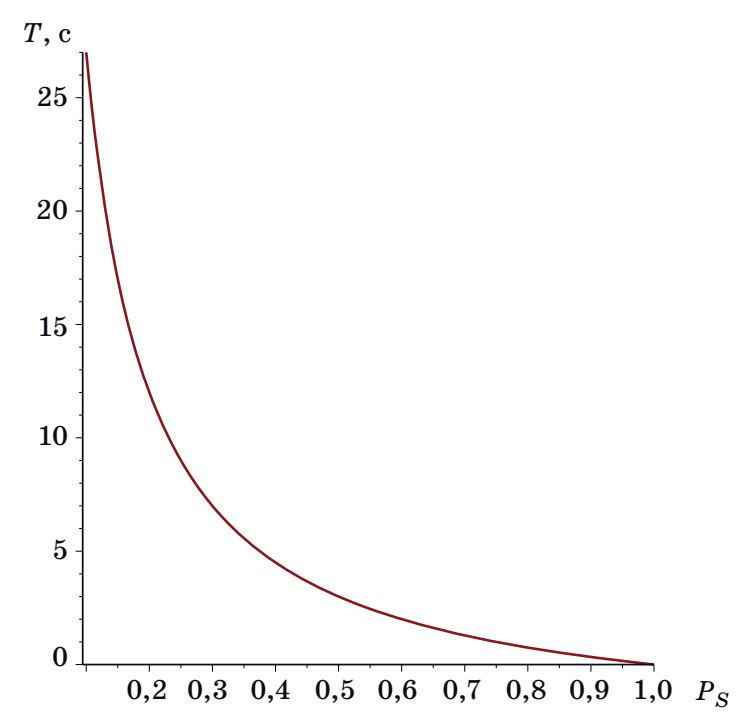

Puc. 7. Среднее время доставки блока данных от сенсорного узла до головного кластерного узла

- Fig. 7. Average delivery time of a data block from the sensor node to the cluster head

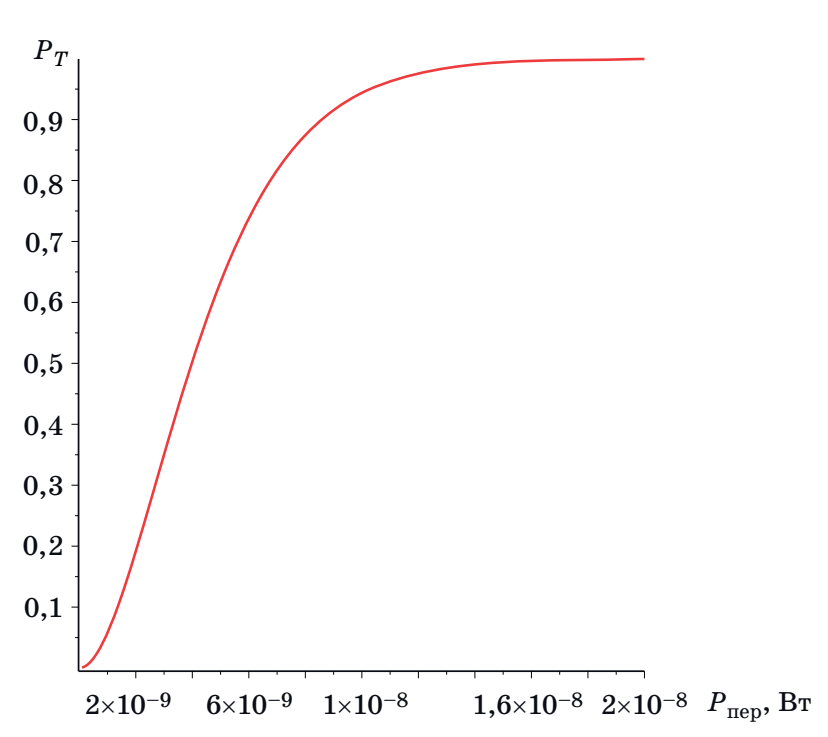

- Puc. 8. Вероятность доставки при $N=3$

- Fig. 8. Delivery probability at $N=3$

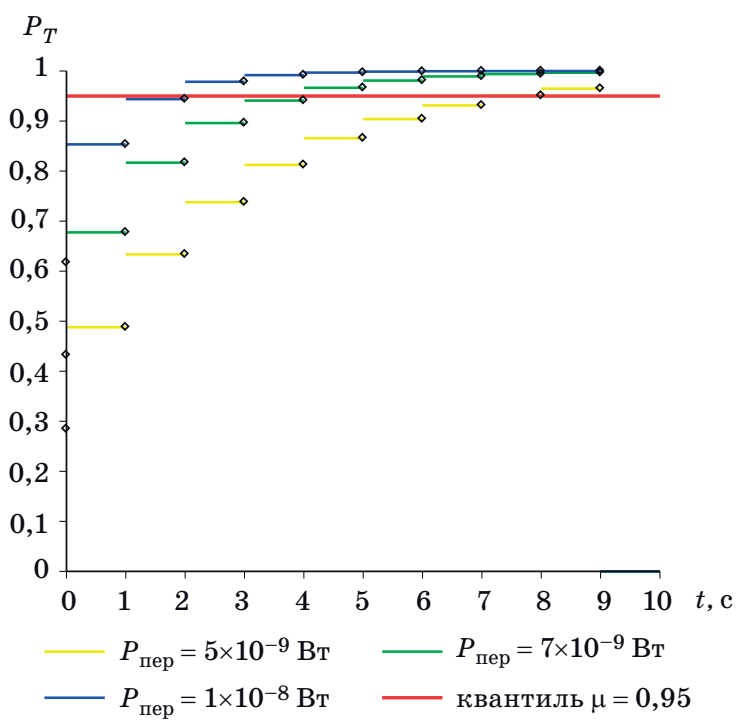

- Puc. 9. Вероятность $P_{T}\left(P_{\text {пер }}\right)$ при различных значениях излучаемой мощности

- Fig. 9. Probability $P_{T}\left(P_{\text {пер}}\right)$ at various values of the radiated power

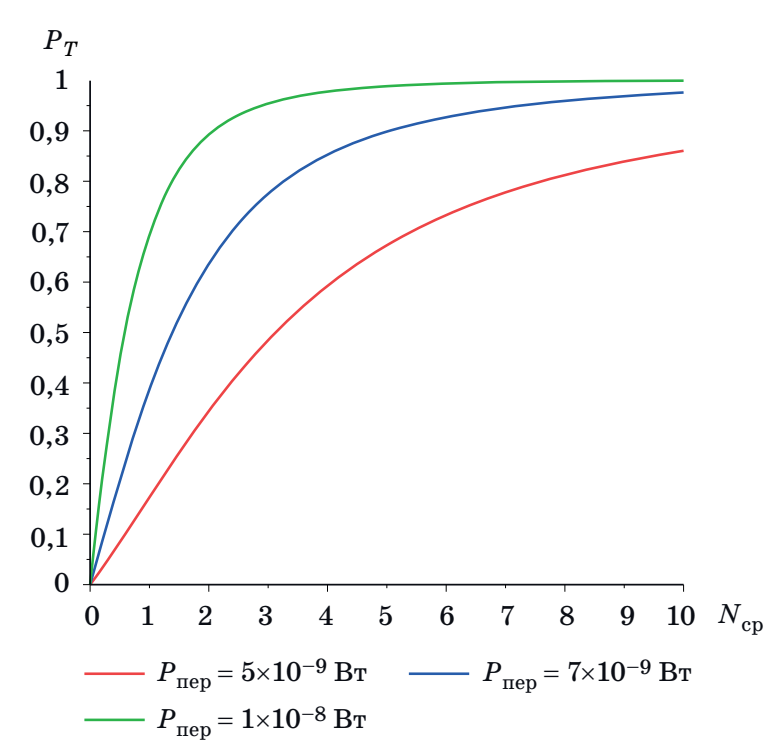

Puc. 10. Зависимость вероятности доставки от количества попыток

- Fig. 10. Dependence of the delivery probability on the number of attempts

дующих исходных данных: $\alpha=\frac{\pi}{4}, \lambda=0,11 / \mathrm{M}^{2}$, $C_{\text {пер }}=1, C_{\text {пр }}=1, \gamma=0,122 \mathrm{м}, X=2$. Предел чувствительности приемника -110 дБм, что соответствует $P_{\text {пр }}=10^{-14}$ Вт. На рис. 5-10 представлены взаимные зависимости временных энергетических и пространственных характеристик беспроводной сенсорной сети. Графики позволяют определить любую из этих характеристик, если заданы две другие. 


\section{Обсуждение}

В качестве одной из метрик для описания устойчивости сети к повреждениям была введена [10, 32] связность сети связи (network connectivity), которая, как правило, оценивалась детерминированными и независимыми от времени характеристиками. Например, в работе [10] связность предлагается определить «как минимальное число параллельных трактов между любой парой узлов». Однако такой подход справедлив лишь для стационарных сетей с фиксированной постоянной неизменной топологией. Когда же речь идет о мобильных сетях, в которых топологическая структура переменна, число, местоположение узлов, их распределение в пространстве случайно и меняется во времени, подобный подход не в полной мере отражает специфику взаимодействия узлов и работы сети.

На стохастическую природу связности указывается в разделе «Терминология» ГОСТ Р 531112008 [33] применительно к «направлению электросвязи»: «вероятность того, что на заданном направлении электросвязи существует хотя бы один путь, по которому возможна передача информации с требуемыми качеством и объемом».

Применительно к беспроводным сенсорным сетям понятие связности исследовалось в работах [14, 19, 34-36]. Так, в [19] отмечается, что в качестве основного параметра функционирования сенсорных сетей целесообразно рассматривать «доступность сети (возможность сети оказывать услугу), которая в свою очередь характеризуется связностью или вероятностью связности». Были представлены [19] модели беспроводных сенсорных сетей, позволяющие оценить связность сети или потенциальные возможности ее обеспечения. Целью исследований являлся «поиск зависимости связности сети от распределения узлов и влияние распределения узлов и их параметров на решение задач по построению сетей с заданными требованиями к связности», а при создании моделей беспроводных сенсорных сетей и исследовании связности рассматривалось и анализировалось влияние пространственных характеристик сети (число, распределение узлов на плоскости и пр.), но не принимались во внимание энергетические параметры устройств беспроводной сети.

Энергопотребление как один из ключевых вопросов для беспроводных сенсорных сетей анализируется, например, в публикациях [2, 37-43]. В работе [2] предлагается решать задачу увеличения времени жизни беспроводной сенсорной сети за счет управления энергетическим балансом приемопередающих узлов, обеспечивающих коррекцию мощности сигналов на основании результатов измерений дальности связи и с учетом особенностей прохождения сигнала в радиоканале и приема, а в статье [43] для обеспечения максимальной продолжительности жизни беспроводной сенсорной сети предусматривается использование многопутевой маршрутизации с поддержкой режима энергетической балансировки узлов сети.

В отличие от указанных работ, в данном исследовании предлагается при определении связности принимать во внимание в комплексе пространственные, временные и энергетические характеристики беспроводных сетей и предложены показатели и модели для проведения соответствующих количественных оценок.

\section{Заключение}

В статье получены следующие научные peзультаты:

- предложена новая стохастическая характеристика качества функционирования беспроводных сенсорных сетей - связность, которая, в отличие от известных, охватывает в комплексе пространственные, временные и энергетические характеристики сети, что позволяет с общих позиций описать широкий комплекс задач, возникающих при исследовании процессов функционирования беспроводных сетей на этапах сбора, распространения и обработки данных сенсорными устройствами;

- введены стохастические показатели связности беспроводных сенсорных сетей, которые, в отличие от известных, описывают сеть как целое, а не свойства ее отдельных элементов, что позволяет исследовать процессы задержки и блокировки информационного обмена с учетом размера сенсорного поля и мощности, потребляемой отдельными устройствами;

- построены модели для оценки вероятности связности беспроводных сенсорных сетей, времени доставки сообщений и квантиля времени доставки, которые, в отличие от известных, учитывают мощность сигнала на выходной антенне сенсорного устройства, используемый частотный диапазон, количество хопов, число попыток передачи сообщений, взаимное расположение сенсорного устройства и головной станции и другие параметры, что позволяет повысить точность оценок качества функционирования беспроводной сенсорной сети.

Полученные модели и методы нацелены на использование при цифровизации сельскохозяйственных организаций и в учебном процессе Княгининского университета.

\section{Финансовая поддержка}

В статье представлена часть результатов научно-исследовательской работы «Сетецентрические 
системы управления цифровым сельским хозяйством посредством сквозных технологий», выполняемой авторами по гранту ГБОУ ВО НГИЭУ

\section{Литература}

1. Верзун Н. А., Колбанев М. О., Татарникова Т. М. Технологическая платформа четвертой промышленной революции. Геополитика и безопасность, 2016, № 2 (34), с. 73-78.

2. Шостко И. С., Куля Ю. Э. Метод увеличения времени жизни автономной беспроводной сенсорной сети за счет применения энергоэффективных режимов работы передатчика. Проблеми телекомунікацій, 2015, № 1 (16), c. 3-15. http://pt.journal.kh.ua/2015/1/1/151_ shostko_ttl.pdf (дата обращения: 29.05.2019).

3. Бакин Е. А., Евсеев Г. С., Смирнов К. Н. Разработка и анализ алгоритмов сбора информации для одной модели телекоммуникационной системы с топологией «правильная решетка». Инфорлационноуправляющие систелы, 2017, № 6, с. 107-112. doi:10.15217/issn1684-8853.2017.6.107

4. Воробьев А. И., Колбанев А. М., Колбанев М. О. Модель оптимизации энергопотребления умными вещами. Известия СПбГЭТУ «ЛЭТИ», 2015, № 7, с. 46-49.

5. Астахова Т. Н., Колбанев М. О., Шамин А. А. Обеспечение энергоэффективности интернета вещей. Региональная информатика и информационная безопасность: сб. науч. тр. Санкт-Петербургское общество информатики, вычислительной техники, систем связи и управления, 2018, с. 203-204.

6. Верзун Н. А., Колбанёв М. О., Шамин А. А. Энергетическая эффективность взаимодействия в беспроводных сенсорных сетях. Информационные технологии и телекомлуникации, 2017, т. 5, № 1, с. 88-96. https://www.sut.ru/ (дата обращения: 29.05.2019).

7. Галинина О. С., Андреев С. Д., Тюрликов А. М. Учет специфики доступа большого числа устройств при межмашинном взаимодействии в современных сотовых сетях. Инфорлаиионно-управляющие системы, 2018, № 4, с. 105-114. doi:10.31799/16848853-2018-4-105-114

8. Воробьев А. И., Колбанёв А. М., Колбанёв М. О. Зеленые информационные технологии. Ученые записки Международного банковского института. СПб., Изд-во МБИ, 2015, вып. 12, с. 153-165.

9. Воробьев А. И., Колбанёв А. М., Колбанёв М. О. Экологическая безопасность информационных технологий. Геополитика и безопасность, 2015, № 4 (32), c. 90-99.

10. Орлов С. А., Цилькер Б. Я. Организация ЭВМ и систел. СПб., Питер, 2015. 688 с.

11. Верзун Н. А., Колбанёв М. О., Омельян А. В. Регулируемый множественный доступ в беспроводной сети умных вещей. Олский научный вестник. Сер. Инфорлатика, вычислительная техника и управление, 2016, № 4 (14), с. 147-151. в рамках базовой части государственного задания № 10/01-41 от 03.03.2017 г.

12. Ерохин С. Д., Махров С. С. Протоколы маршрутизации в беспроводных сенсорных сетях: основанные на местоположении узлов и направленные на агрегацию данных. T-Coтm-Телеколмуникации $u$ транспорт, 2013, № 3, с. 44-47.

13. Махров С. С. Исследование связности узлов в иерархических протоколах беспроводных сенсорных сетей. Фундалентальные проблель радиоэлектронного приборостроения, 2013, т. 13, № 4, с. 186-189.

14. Батенков К. А., Батенков А. А. Анализ и синтез структур сетей связи по детерминированным показателям устойчивости. Труды СПИИРАН, 2018, т. 3, № 58, с. 128-159.

15. Lee H., Nguyen L. T. H., Fujisaki Y. Algebraic connectivity of network-of-networks having a graph product structure. Systems \& Control Letters, 2017, vol. 104, pp. 15-20.

16. Chen C., Peng R., Ying L., Tong H. Network connectivity optimization: Fundamental limits and effective algorithms. Proceedings of the 24th ACM SIGKDD International Conference on Knowledge Discovery \& Data Mining, 2018, pp. 1167-1176.

17. Mishra S., Raj A., Kayal A., Choudhary V., Verma P., Biswal L. Study of cluster based routing protocols in wireless sensor networks. International Journal of Scientific \& Engineering Research, 2012, vol. 3, no. 7, pp. 1-7.

18. Awasthi K. K., Singh A. K., Tahilyani S. Study of cluster based routing protocols in wireless sensor networks. International Journal of Computer Applications, 2017, vol. 163, no. 1, pp. 39-42.

19. Окунева Д. В. Разработка и исследование моделей беспроводных сенсорных сетей при неравнолернол распределении узлов: дис. ... канд. техн. наук. СПб., 2017. $159 \mathrm{c}$.

20. Кучерявый А. Е., Салим А. Выбор головного узла кластера в однородной беспроводной сенсорной сети. Электросвязь, 2009, № 8, с. 32-36.

21. Handy M. J., Haase M., Timmermann D. Low energy adaptive clustering hierarchy with deterministic cluster-head selection. 4th International Workshop on Mobile and Wireless Communications Network, 2002, pp. 368-372.

22. Heinzelman W. B., Chandrakasan A. P., Balakrishnan H. An application-specific protocol architecture for wireless microsensor networks. IEEE Transactions on Wireless Communications, 2002, vol. 1, no. 4, pp. 660-670.

23. Karl H., Willig A. Protocols and architectures for wireless sensor networks. John Wiley \& Sons, 2007. $526 \mathrm{p}$.

24. Богатырев В. А., Богатырев А. В., Голубев И. Ю., Богатырев С. В. Оптимизация распределения за- 
просов между кластерами отказоустойчивой вычислительной системы. Научно-технический вестник инфорлационных технологий, механики и оптики, 2013, № 3(85), с. 77-82.

25. Богатырев В. А., Богатырев С. В. Надежность мультикластерных систем с перераспределением потоков запросов. Известия высших учебных заве дений. Приборостроение, 2017, т. 60, № 2, с. 171177.

26. Уоллес Р. Максимальная дальность связи по радиоканалу в системе: как этого добиться? Новости электроники, 2015, № 11, с. 3-13.

27. Глушков В. М., Амосов Н. М., Артеменко И. А. Энииклопедия кибернетики. Киев, Главная редакция украинской советской энциклопедии, 1974. $608 \mathrm{c.}$

28. Koucherjavyj Y., Pyattaev A., Johnsson K., Galinina 0. Cellular traffic offloading onto network-assisted device-to-device connections. IEEE Communications Magazine, 2014, vol. 52, no. 4, pp. 20-31.

29. Мутханна А. С., Кучерявый А. Е. D2D-коммуникации в сетях мобильной связи пятого поколения 5G. Инфорлационные технологии и телеколмуникации, 2014, вып. 4 (8), с. 51-63.

30. Osseiran A., et al. Scenarios for 5G mobile and wireless communications: the vision of the METIS project. IEEE Communications Magazine, 2014, vol. 52, no. 5, pp. 26-35.

31. Бородин А. С. Разработка и исследование методов построения сетей связи пятого поколения: дис. ... канд. техн. наук. СПб., 2019. 124 с.

32. Суздалев А. В. Сети передачи инфорлации АСУ. М., Радио и связь, 1983. 152 с.

33. ГОСТ Р 53111-2008. Устойчивость функционирования сети связи общего пользования. Требования и методы проверки. М., Стандартинформ, 2009. $16 \mathrm{c}$.

34.Бузюков Л. Б., Парамонов А. И., Окунева Д. В. Анализ связности БСС при различных распределениях узлов. 71-я Всероссийская научно-техническая конферениия, посвященная Дню радио: труды конферениии, СПб., 2016, с. 179-180.
35. Бузюков Л. Б., Парамонов А. И., Окунева Д. В. Анализ связности самоорганизующейся беспроводной сети при различном распределении узлов по территории. Электросвязь, 2016, № 9, с. 58-62.

36. Кучерявый А. Е., Нуриллоев И. Н., Парамонов А. И., Прокопьев А. В. Обеспечение связности беспроводных сенсорных узлов гетерогенной сети. Инфорлаиионные технологии и телеколмуникации, 2015, № 1 (9), c. 115-122.

37. Liu M., Cao J., Chen G., Wang X. An energy-aware routing protocol in wireless sensor networks. Sensors, 2009, vol. 9, no. 1, pp. 445-462.

38. Adeel A., Abid A., Sohail J. Energy aware intra cluster routing for wireless sensor networks. International Journal of Hybrid Information Technology, 2010, vol. 3, no. 1, pp. 1-6.

39. Amgoth T., Jana P. K. Energy-aware routing algorithm for wireless sensor networks. Computers \& Electrical Engineering, 2015, vol. 41, pp. 357-367.

40. Ayoub N., Asad M., Aslam M., Gao Z., Munir E. U., Tobji R. MAHEE: Multi-hop advance heterogeneity-aware energy efficient path planning algorithm for wireless sensor networks. 2017 IEEE Pacific Rim Conference on Communications, Computers and Signal Processing (PACRIM), 2017, pp. 1-6.

41. Shah S. B., Chen Z., Yin F., Khan I. U., Ahmad N. Energy and interoperable aware routing for throughput optimization in clustered IoT-wireless sensor networks. Future Generation Computer Systems, 2018, vol. 81 , pp. 372-381.

42. Восков Л. С., Комаров М. М. Метод энергетической балансировки беспроводной стационарной сенсорной сети с автономными источниками питания. Бизнес-инфорлатика, 2012, № 1 (19), с. 70-75.

43. Шостко И. С., Куля Ю. Э. Разработка модели маршрутизации беспроводной сенсорной сети с учетом устранения дисбаланса энергопотребления. Технологический аудит и резервы производства, 2015, № 3/2(23), c. 94-98. 
UDC 004.051, 621.391, 621.396

doi:10.31799/1684-8853-2019-5-38-50

\section{Sensor network connectivity models}

T. N. Astakhova ${ }^{a}$, PhD, Phys.-Math., Associate Professor, orcid.org/0000-0002-7032-0697, ctn_af@mail.ru

N. A. Verzun ${ }^{b, c}$, PhD, Tech., Associate Professor, orcid.org/0000-0002-0126-2358

V. V. Kasatkin ${ }^{\text {, }}$ PhD, Tech., Associate Professor, orcid.org/ 0000-0001-7523-4926

M. O. Kolbanev b,c , Dr. Sc., Tech., Professor, orcid.org/0000-0003-4825-6972

A. A. Shamin ${ }^{\text {a }}$ PhD, Econom., Associate Professor, orcid.org/0000-0001-7690-8718

aNizhny Novgorod State University of Engineering and Economics, 22a, Oktyabrskaya St., 606340, Knyaginino,

Russian Federation

bSaint-Petersburg Electrotechnical University «LETI», 5, Prof. Popov St., 197376, Saint-Petersburg, Russian

Federation

'Saint Petersburg State University of Economics, 21, Sadovaya St., 191023, Saint-Petersburg, Russian Federation

dSaint-Petersburg Institute for Informatics and Automation of the RAS, 39, 14 Line, V. O., 199178, Saint-Petersburg,

Russian Federation

Introduction: One of the key areas in the research of wireless sensor networks is studying the ways to increase the battery life by saving energy in individual devices. The article introduces and discusses a new energy-efficient stochastic measure of the quality parameter for a wireless sensor network - connectivity, which reflects the ability of a network to establish connections between its elements within the boundaries of the sensor field in real time, at a certain level of the sensor device battery charge. Purpose: Identifying the interdependence between the probability-time and probability-energy characteristics, as well as the influence, on these characteristics, of such parameters as geometric dimensions, distribution model of sensor devices within the sensor field, network topology and message routing algorithms. Results: A new stochastic characteristic of wireless sensor network functioning quality is proposed, called connectivity. It encompasses the spatial, temporal and energy characteristics of the network, making it possible to describe, from a general point of view, a wide range of problems which arise when you study the functioning of wireless networks at the stages of data collecting, distributing and processing by the sensors. Stochastic connectivity indicators are introduced for wireless sensor networks, describing a network as a whole and allowing you to investigate the delay and blocking of the information exchange, taking into account the size of the sensor field and the power consumed by individual devices. Models are built for assessing the probability of wireless sensor network connectivity, message delivery time and delivery time quantile, improving the accuracy of network quality assessments. Practical relevance: The obtained models and methods are supposed to be used in digitalization of agricultural organizations and in the educational process at Knyagininsky University.

Keywords - wireless sensor network, probability-time characteristics, probability-energy characteristics, connectivity probability, message delivery time, cluster, signal power at the transmitting antenna, network connectivity, $\mu$-quantile of delivery time.

For citation: Astakhova T. N., Verzun N. A., Kasatkin V. V., Kolbanev M. O., Shamin A. A. Sensor network connectivity models. Informatsionno-upravliaiushchie sistemy [Information and Control Systems], 2019, no. 5, pp. 38-50 (In Russian). doi:10.31799/16848853-2019-5-38-50

\section{References}

1. Verzun N. A., Kolbanev M. O., Tatarnikova T. M. The technological platform of the fourth industrial revolution. Geopolitika i bezopasnost, 2016, no. 2 (34), pp. 73-78 (In Russian).

2. Shostko I. S., Kulya Yu. E. The method of increasing the life time of an autonomous wireless sensor network due to the application of energy efficient operating modes of the transmitter. Problemy telekomunikatsiy, 2015, no. 1 (16), c. 3-15. Available at: http://pt.journal.kh.ua/2015/1/1/151 shostko ttl.pdf. (accessed 29 May 2019) (In Russian).

3. Bakin E. A., Evseev G. S., Smirnov K. N. Algorithms of convergecast schedule calculation for a sensor network model with regular grid topology. Informatsionno-upravlyayushchiye sistemy [Information and Control Systems], 2017, no. 6, pp. 107-112 (In Russian). doi:10.15217/issn16848853.2017.6.107

4. Vorobev A. I., Kolbanev A. M., Kolbanev M. O. Model energy optimization clever things. Izvestiya SPbGETU "LETI", 2015, no. 7, pp. 46-49 (In Russian).

5. Astakhova T., Kolbanev M., Shamin A. Obespechenie energoeffektivnosti interneta veshchej In: Regional'naya infor matika i informacionnaya bezopasnost' [Energy efficiency support of the internet of things. In: Scientific collection "Regional informatics and information security"]. Saint-Petersburg, Sankt-Peterburgskoe obshchestvo informatiki, vychislitel'noj tekhniki, sistem svyazi i upravleniya Publ., 2018. Pp. 203-204 (In Russian).

6. Verzun N., Kolbanev M., Shamin A. The energy efficiency of cooperation in wireless sensor networks. Telecom IT, 2017, vol. 5, no. 1, pp. 88-96. Available at: https://www.sut. $\mathrm{ru}$ (accessed 29 May 2019) (In Russian).

7. Galinina O. S., Andreev S. D., Tyurlikov A. M. On multiple access of a large number of machine-type devices in cellular networks. Informatsionno-upravlyayushchiye sistemy [Information and Control Systems], 2018, no. 4, pp. 105-114 (In Russian). doi:10.31799/1684-8853-2018-4-105-114

8. Vorobyov A. I., Kolbanyov A. M., Kolbanyov M. O. Green IT. Uchenyye zapiski Mezhdunarodnogo bankovskogo instituta. Saint-Petersburg, MBI Publ., 2015, iss. 12, pp. 153-165 (In Russian).

9. Vorobyov A. I., Kolbanyov A. M., Kolbanyov M. O. Ecological safety of information technology. Geopolitika i bezopas nost, 2015, no. 4 (32), pp. 90-99 (In Russian).

10. Orlov S. A., Tsilker B. Ya. Organizatsiya EVM i system [Computer Organization and Systems]. Saint-Petersburg, Piter Publ., 2015. 688 p. (In Russian).

11. Verzun N. A., Kolbanev M. O., Omelyan A. V. Controlled multiple access in wireless network of smart things. Omsk Scientific Bulletin, 2016, no. 4 (14), pp. 147-151 (In Russian).

12. Erohin S., Makhrov S. S. Routing protocols in wireless sensor networks: locationbased units and aimed at the aggregation of data. T-Comm-Telekommunikatsii i Transport, 2013, no. 3, pp. 44-47 (In Russian).

13. Makhrov S. S. Investigation of the connectivity of nodes in hierarchical protocols of wireless sensor networks. Fundamental'nyye problemy radioelektronnogo priborostroyeniya, 2013 , vol. 13, no. 4, pp. 186-189 (In Russian).

14. Batenkov K. A., Batenkov A. A. Analysis and synthesis of communication network structures according to the determined stability. SPIIRAS Proceedings, 2018, vol. 3, no. 58, pp. 128-159 (In Russian).

15. Lee H., Nguyen L. T. H., Fujisaki Y. Algebraic connectivity of network-of-networks having a graph product structure. Systems \& Control Letters, 2017, vol. 104, pp. 15-20.

16. Chen C., Peng R., Ying L., Tong H. Network connectivity optimization: Fundamental limits and effective algorithms. 
Proceedings of the 24th ACM SIGKDD International Confer ence on Knowledge Discovery \& Data Mining, 2018, pp. 1167-1176.

17. Mishra S., Raj A., Kayal A., Choudhary V., Verma P., Biswal L. Study of cluster based routing protocols in wireless sensor networks. International Journal of Scientific \& Engineering Research, 2012, vol. 3, no. 7, pp. 1-7.

18. Awasthi K. K., Singh A. K., Tahilyani S. Study of cluster based routing protocols in wireless sensor networks. Inter national Journal of Computer Applications, 2017, vol. 163, no. 1 , pp. $39-42$.

19. Okuneva D. V. Razrabotka $i$ issledovaniye modeley be sprovodnykh sensornykh setey pri neravnomernom raspre delenii uzlov. Dis. cand. tech. nauk [Development and research of wireless sensor networks with uneven distribution of nodes. PhD tech. sci. diss.]. Saint-Petersburg, 2017. 159 p. (In Russian).

20. Koucheryavy A. E., Salim A. Cluster headend selection for homogeneous wireless sensor networks. Elektrosvyaz, 2009, no. 8, pp. 32-36 (In Russian).

21. Handy M. J., Haase M., Timmermann D. Low energy adaptive clustering hierarchy with deterministic cluster-head selection. 4th International Workshop on Mobile and Wireless Communications Network, 2002, pp. 368-372.

22. Heinzelman W. B., Chandrakasan A. P., Balakrishnan H. An application-specific protocol architecture for wireless microsensor networks. IEEE Transactions on Wireless Communications, 2002 , vol. 1 , no. 4, pp. 660-670.

23. Karl H., Willig A. Protocols and architectures for wireless sensor networks. John Wiley \& Sons, 2007. 526 p.

24. Bogatyrev V. A., Bogatyrev A. V., Golubev I. Y., Bogatyryev S. V. Queries distribution optimization between clusters of fault-tolerant computing system. Scientific and Technical Journal of Information Technologies, Mechanics and Optics, 2013, no. 3(85), pp. 77-82 (In Russian).

25. Bogatyrev V. A., Bogatyrev S. V. Reliability of multi-cluster systems with redistribution of the flow of requests. Journal of Instrument Engineering, 2017, vol. 60, no. 2, pp. 171-177 (In Russian).

26. Uolles $\mathrm{R}$. Maximum radio communication range in the system: how to achieve this? Novosti elektroniki, 2015, no. 11, pp. 3-13 (In Russian).

27. Glushkov V. M., Amosov N. M., Artemenko I. A. Entsiklope diya kibernetiki [Encyclopedia of Cybernetics]. Kiev, Glavnaya redaktsiya ukrainskoy sovetskoy entsiklopedii, 1974. 608 p. (In Russian).

28. Koucherjavyj Y., Pyattaev A., Johnsson K., Galinina O. Cellular traffic offloading onto network-assisted device-to-device connections. IEEE Communications Magazine, 2014, vol. 52 , no. 4 , pp. $20-31$.

29. Muthanna A. S., Koucheryavy A. Y. D2D-communication in the 5G mobile networks. Telecom IT, 2014, vol. 4 (8), pp. 51-63 (In Russian).

30. Osseiran A., et al. Scenarios for $5 \mathrm{G}$ mobile and wireless communications: the vision of the METIS project. IEEE Communications Magazine, 2014, vol. 52, no. 5, pp. 26-35.
31. Borodin A. S. Razrabotka i issledovaniye metodov postroy eniya setey suyazi pyatogo pokoleniya. Dis. cand. tech. nauk [Development and Research of Methods for Building Communication Networks of the Fifth Generation. PhD tech. sci. diss.]. Saint-Petersburg, 2019. 124 p. (In Russian).

32. Suzdalev A. V. Seti peredachi informatsii ASU [Networks of information transfer of ACS]. Moscow, Radio i svyaz Publ. 1983. 152 p. (In Russian).

33. State Standard 53111-2008. The stability of the public com munication network. Requirements and verification meth ods. Moscow, Standardinform Publ., 2009. 16 p. (In Russian).

34. Okuneva D. V., Buzyukov L. B., Paramonov A. I. Analysis of wireless sensor network's connectivity using a variety of nodes distribution. Trudy 71-j Vserossijskoj nauchno-tekhnicheskoj konferencij, posvyashchennoj Dnyu radio [Proc. 71st All-Russian Scientific and Technical Conference Dedicated to the Day of Radio], Saint-Petersburg, 2016, pp. 179180 (In Russian).

35. Okuneva D. V., Buzyukov L. B., Paramonov A. I. Analysis of wireless self-organizing network's connectivity using a variety of nodes distribution on territory. Elektrosvyaz, 2016, no. 9, pp. 58-62 (In Russian).

36. Koucheryavy A. E., Nurilloev I. N., Paramonov A. I. Prokopiev A. V. Provision of connectivity of wireless sensor nodes in heterogeneous network. Telecom IT, 2015, no. 1 (9), pp. 115-122 (In Russian).

37. Liu M., Cao J., Chen G., Wang X. An energy-aware routing protocol in wireless sensor networks. Sensors, 2009, vol. 9, no. 1 , pp. 445-462.

38. Adeel A., Abid A., Sohail J. Energy aware intra cluster routing for wireless sensor networks. International Journal of Hybrid Information Technology, 2010, vol. 3, no. 1, pp. $1-6$.

39. Amgoth T., Jana P. K. Energy-aware routing algorithm for wireless sensor networks. Computers \& Electrical Engineer ing, 2015, vol. 41, pp. 357-367.

40. Ayoub N., Asad M., Aslam M., Gao Z., Munir E. U., Tobji R. MAHEE: Multi-hop advance heterogeneity-aware energy efficient path planning algorithm for wireless sensor networks. 2017 IEEE Pacific Rim Conference on Communications, Computers and Signal Processing (PACRIM), 2017, pp. $1-6$.

41. Shah S. B., Chen Z., Yin F., Khan I. U., Ahmad N. Energy and interoperable aware routing for throughput optimization in clustered IoT-wireless sensor networks. Future Generation Computer Systems, 2018, vol. 81, pp. 372-381.

42. Voskov L., Komarov M. Method of energy balancing in a static wireless sensor networks with autonomous energy sources. Biznes-informatika, 2012, no. 1 (19), pp. 70-75 (In Russian).

43. Shostko I. S., Kulya Yu. E. Development of a routing model for a wireless sensor network, taking into account the elimination of energy imbalance. Tekhnologicheskiy audit rezervy proizvodstva, 2015, no. 3/2 (23), pp. 94-98 (In Russian). 


\section{Оценка эффективности механизма резервирования полосы пропускания для технологии mmWave в сетях связи пятого поколения}

В. О. Бегишева, канд. физ.-мат. наук, ассистент, orcid.org/0000-0002-7232-4157, begishev-vo@rudn.ru

Э. С. Сопина, б, канд. физ.-мат. наук, доцент, orcid.org/0000-0001-9082-2152

Д. А. Молчанова, в, канд. техн. наук, доцент, orcid.org/0000-0003-4007-7187

А. К. Самуйлова, в, канд. физ.-мат. наук, доцент, orcid.org/0000-0002-2087-769X

Ю. В. Гайдамакаа,

К. Е. Самуйлова, б, доктор техн. наук, профессор, orcid.org/0000-0002-6368-9680

ароссийский университет дружбы народов, Миклухо-Маклая ул., 6, Москва, 117198, РФ

бИнститут проблем информатики Федерального исследовательского центра «Информатика

и управление» РАН, Вавилова ул., 44-2, Москва, 119333, РФ

вТехнологический университет г. Тампере, Коркеакоулункату, 10, Тампере, 33100, финляндия

Введение: в системах $3 G P P$ NR частые блокировки прямой видимости между приемо-передающими устройствами могут привести к сбросу уже принятых в систему сессий, обслуживание которых не завершено, что снижает качество предоставления услуг пользователям сети связи. Одним из способов повысить непрерывность сессий является механизм резервирования ресурса базовой станции для принятых в систему сессий. Цель: разработка математической модели для анализа влияния механизма резервирования радиодиапазона на основные показатели качества обслуживания в сети $5 G$ с учетом ключевых особенностей технологии 3GPP NR, включая высоту взаимодействующих объектов, геометрию и мобильность блокеров, миллиметровый диапазон передачи, модуляционно-кодовые схемы, антенные решетки, а также прямую видимость между приемо-передающими устройствами. Результаты: построена математическая модель в виде ресурсной системы массового обслуживания с сигналами, где радиодиапазон базовой станции соответствует ресурсу, а сигналы моделируют изменение условий прямой видимости между приемо-передающими устройствами. Создание приоритета для сессий, чье обслуживание еще не завершено, обеспечивает значительную гибкость для балансировки непрерывности сессии и отказа в установлении новой сессии за счет небольшого снижения эффективности использования радиоресурса. С использованием разработанной модели показано, что управление доступом к ресурсу посредством резервирования даже небольшой полосы пропускания (менее 10 \% от общего объема ресурсов) для поддержания сессий, уже принятых на обслуживание, положительно влияет на непрерывность сессий, поскольку заметно увеличивает вероятность их успешного завершения. Практическая значимость: предложенный механизм эффективнее работает в условиях перегрузки и с сессиями, имеющими высокие требования к скорости передачи данных, что повышает его востребованность для систем связи $5 \mathrm{G} N \mathrm{~N}$.

Ключевые слова - миллиметровый диапазон, беспроводные сети пятого поколения, резервирование полосы пропускания, вероятность потери поступающей сессии, вероятность принятой на обслуживание сессии, коэффициент использования ресурса.

Для цитирования: Бегишев В. О., Сопин Э. С., Молчанов Д. А., Самуйлов А. К., Гайдамака Ю. В., Самуйлов К. Е. Оценка эффективности механизма резервирования полосы пропускания для технологии mmWave в сетях связи пятого поколения. Информационно-управляющие системы, 2019, № 5, с. 51-63. doi:10.31799/1684-8853-2019-5-51-63

For citation: Begishev V. O., Sopin E. S., Molchanov D. A., Samouylov A. K., Gaidamaka Yu. V., Samouylov K. E. Performance evaluation of bandwidth reservation for mmWave in $5 \mathrm{G}$ NR systems. Informatsionno-upravliaiushchie sistemy [Information and Control Systems], 2019, no. 5, pp. 51-63 (In Russian). doi:10.31799/1684-8853-2019-5-51-63

\section{Введение}

Ожидается, что семейство технологий, объединенных под общим названием «новое радио 5G» (5G New Radio, 5G NR), станет стандартным решением для мобильных систем $5 \mathrm{G}$, обеспечивая высокую пропускную способность и малые задержки на беспроводном интерфейсе [1]. Предварительные требования к технологиям $5 \mathrm{G}$ NR были выдвинуты некоммерческим консорциумом 3rd Generation Partnership Project (3GPP), разрабатывающим спецификации для мобильной телефонии, и появились в Release 15 [2], приня- том в декабре 2017 г., а в декабре 2019 г. ожидается утверждение окончательной версии стандарта 5G NR. Одной из основных отличительных особенностей радиотехнологии 5G NR является добавление новых диапазонов радиоспектра в пределах от 2,5 до 40 ГГц, в будущем - до 100 ГГц, включающих миллиметровый диапазон длин волн. В то время как процесс стандартизации $5 \mathrm{G}$ NR почти завершен и производители оборудования уже проводят тестовые испытания [3], фокус научных исследований смещается в сторону улучшения показателей эффективности новой сети доступа, при этом исследуются как особенно- 
сти сетевого трафика [4], так и новые технологии, реализованные в современных сетях [5].

Высокая направленность антенн миллиметрового диапазона позволяет передавать сигнал на значительные расстояния, однако сужение лучей антенны приводит к возможности блокировки распространения радиоволн миллиметрового диапазона малыми объектами, такими как человеческие тела, деревья, столбы освещения. Блокировка распространения радиоволн возникает при появлении препятствия, или блокера, на линии прямой видимости (Line-of-Sight - LoS) между приемо-передающими устройствами, например точкой доступа и оборудованием пользователя. Следствием этого являются резкие кратковременные скачки уровня принимаемого сигнала, которые не удается компенсировать с помощью современных методов обработки сигналов. В последнее время было предпринято несколько попыток исследовать этот процесс для различных сценариев движения объектов, например, модель блокировки прямой видимости со стационарными блокерами и подвижными пользователями была разработана авторами работы [6], а симметричный сценарий с мобильными блокерами и статичными пользователями проанализирован в работе [7]. В зависимости от расстояния между приемо-передающими устройствами на случай блокировки прямой видимости в системах NR предусмотрены два принципиально разных механизма для поддержания уже установленной сессии: механизм множественного подключения [8-11] пользовательского оборудования (ПО), находящегося в отдалении от точки доступа, например от базовой станции (БС), и механизм резервирования ресурсов [12] для ПО вблизи БС.

При блокировке прямой видимости для пользователя, находящегося на значительном расстоянии от обслуживающей его БС, суммарная мощность отраженных сигналов, принимаемых ПО от БС, оказывается ниже порогового значения отношения сигнал/шум (ОСШ), что приводит к невозможности поддержания установленной через эту БС сессии. Обеспечить непрерывность сессии в этой ситуации позволяет предложенный консорциумом 3GPP механизм множественного подключения [10], согласно которому ПО разрешается использовать пространственное разнесение передачи путем установления одновременных соединений с несколькими БС, находящимися в непосредственной близости. В течение сессии в случае блокировки текущего активного соединения ПО перенаправляет свой трафик на другую незаблокированную в данный момент БС [12].

Для пользователя, находящегося вблизи обслуживающей его БС, при блокировке прямой видимости мощность принимаемого сигнала остается выше порогового значения, однако ее может быть недостаточно для поддержания определенной для данной сессии скорости передачи данных. В этом случае потерянную из-за блокировки прямой видимости мощность можно компенсировать выделением дополнительных радиоресурсов. В статье [12] авторы предложили механизм резервирования ресурсов системы, согласно которому часть радиоресурсов недоступна для новых сессий пользователя; она зарезервирована для обеспечения непрерывности сессий, уже принятых на обслуживание. Благодаря резервированию установленная через БС сессия для ПО при блокировке прямой видимости (non-Line-of-Sight - nLoS) не будет прервана, а продолжит обслуживание через ту же БС. Основным преимуществом предложенного механизма резервирования является то, что он может быть использован на отдельно стоящих NR БC и не требует развертывания плотных сетей, что делает это решение подходящим для ранних этапов проникновения технологии NR на рынок. Кроме того, такой механизм не требует одновременной поддержки соединения несколькими БС, что снижает энергопотребление узлов сети.

В настоящей работе построена и проанализирована математическая модель системы, характеризующая производительность NR БС в условиях резервирования части ресурсов для случая стационарных приемо-передающих устройств и подвижных блокеров. В отличие от [12], модель учитывает зависящие от расстояния между БС и ПО модуляционно-кодовые схемы, применяемые в стандарте NR БC, а также возможность многократной блокировки прямой видимости между БС и ПО в течение одной сессии. Также приняты во внимание характерные особенности распространения волн миллиметрового диапазона частот, модель перемещения блокеров и учтены детали процесса обслуживания NR на основе резервирования ресурсов.

\section{Системная модель и принятые допущения}

Объектом исследования является фрагмент сети 5G, состоящий из точки доступа - БС, работающей в стандарте 3GPP 5G NR, и оборудования пользователей, находящихся в зоне покрытия БС. Пользователь отправляет на БС запрос на получение услуги связи, при предоставлении которой должна быть установлена и в течение всего времени получения услуги поддерживаться сессия между БС и ПО. Объем ресурса, который выделяется на БС для обслуживания сессии, зависит от местоположения ПО и условий прямой видимости между БС и ПО и может меняться во времени при изменении этих факторов. Предметом исследования является влияние механизма резервирования, предложенного в статье, на харак- 
теристики, ориентированные на пользователя, а именно вероятность потери запроса на установление сессии и вероятность преждевременного завершения принятой на обслуживание сессии, а также на коэффициент использования ресурса БС, который относится к системо-ориентированным характеристикам.

Мы начнем с описания моделирования расположения и формы узлов сети, затем перейдем к моделированию распространения сигнала и его блокировки в отсутствие прямой видимости, опишем принципы выделения ресурса для обслуживания сессии с учетом предложенного [12] механизма резервирования ресурсов. Завершим раздел введением интересующих нас характеристик производительности системы.

На рис. 1, а изображена одна NR БC с высотой $h_{A}$ и несколько пешеходов с абонентскими устройствами ПО, которые перемещаются в ее зоне покрытия, имеющей форму круга радиуса $d_{E}$. Предполагается, что значение $d_{E}$ выбрано с учетом высоты $h_{U}$ расположения ПО. Далее в разделе будет показано, как оценить радиус $d_{E}$ для модели распространения сигнала и набора модуляционно-кодовых схем (Modulation and Coding Schemes - MSC), указанных для технологии NR в Release 15 [1]. Плотность пешеходов задается распределением Пуассона с параметром $\lambda_{B}$ пешеходов на квадратный метр [13].

Иллюстрация динамической блокировки путей распространения радиосигнала показана на рис. 1, б. Пешеходы перемещаются в пределах 3оны обслуживания БС согласно модели случайного блуждания Random Direction Model (RDM) [14] со скоростью $v$ [м/c] и экспоненциально распределенной длиной траектории в среднем $\tau$ метров.
Движущийся пешеход может на время стать блокатором прямой видимости для неподвижного пешехода - пользователя сети, установившего сессию с БС. Потоки пешеходов через границу зоны покрытия БС считаются постоянными и равными в обоих направлениях. Пешеходы моделируются цилиндрами с высотой $h_{B}$ и радиусом основания $r_{B}$. Высота пешеходов соответствует среднему росту человека и принимается равной $h_{B}=1,7$ м, при этом ПО находится на высоте $h_{U}=1,7$ м. В зависимости от условий прямой видимости и расстояния между БС и ПО для поддержки надежной передачи данных используется соответствующая модуляционно-кодовая схемa [2].

Пешеходы являются также источниками запросов на установление сессии. Поток запросов, поступающих на БС, предполагаем пуассоновским с параметром, зависящим от интенсивности $\lambda$ запросов на установление сессии на квадратный метр, а также от площади зоны покрытия $\pi d_{E}^{2}$. Предполагаем, что пользователи, генерирующие запросы, неподвижны и равномерно распределены в пределах зоны покрытия БС. Длительность сессии имеет экспоненциальное распределение с средним $1 / \mu$. Для обслуживания принятой в систему сессии помимо занятия прибора требуется случайный объем ресурса в соответствии с некоторой функцией распределения (ФР) $F_{R}(x), x>0$.

Принятая в систему сессия может быть сброшена до завершения предоставления пользователю услуги, если при изменении условий прямой видимости доступный свободный ресурс на БС недостаточен для поддержания сессии, т. е. для передачи данных с требуемой для запрошенной услуги скоростью. Появление и исчезновение a)

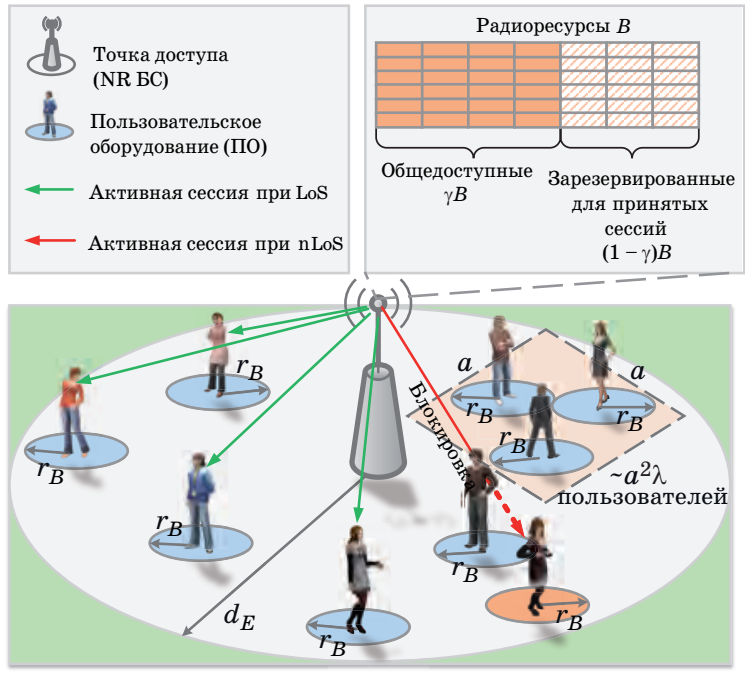

б)

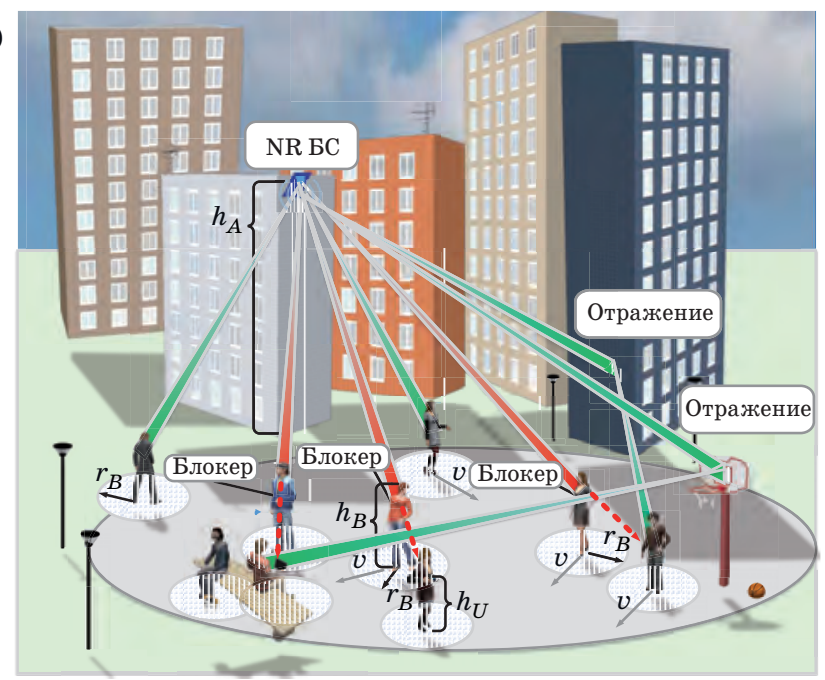

- Puc. 1. Компоненты анализируемой системы: $a$ - модель развертывания сети; б - модель блокировки

- Fig. 1. Components of the system model: $a$ - network deployment model; $\sigma$ - lock model 
блокера на линии прямой видимости между БС и соответствующим ПО моделируется с помощью поступающих на БС сигналов прерывания, интервалы между которыми полагаем экспоненциально распределенными с параметром $\alpha$. После поступления сигнала прерывания требование к ресурсу для продолжения обслуживания сессии меняется, при этом увеличение требования $\kappa$ ресурсу соответствует появлению, а уменьшение - исчезновению блокера на линии прямой видимости между БС и ПО.

Считаем, что БС имеет ресурс объема $B$ [Гц]. Механизм резервирования [12] предполагает, что только часть ресурса, а именно $\gamma B$, доступна для запросов на установление новой сессии, в то время как для сессий, уже принятых в систему, доступен весь объем ресурса. Резервирование доли $(1-\gamma)$ ресурса для принятых на обслуживание сессий предназначено для их защиты от сброса, если блокировка прямой видимости между БС и ПО произойдет в состоянии, когда весь общедоступный ресурс занят.

При поступлении запроса на установление новой сессии на БС проверяется, достаточно ли свободного ресурса в доступной для новых запросов части для обслуживания поступившего запроса. В случае положительного ответа устанавливается новая сессия, при этом суммарный объем занятого ресурса в системе увеличивается на величину требования, иначе запрос на установление сессии теряется, не изменяя объема занятого ресурса.

После поступления сигнала прерывания занятый обслуживанием сессии ресурс освобождается, и требование $\kappa$ ресурсу для продолжения обслуживания этой сессии разыгрывается заново с той же $\Phi$ Р $F_{R}(x), x>0$. Если новое требование к ресурсу не превосходит старое, т. е. при исчезновении блокера, сессия продолжает свое обслуживание, при этом суммарный занятый ресурс уменьшается на величину разницы между требованиями. Если новое требование к ресурсу превосходит старое, т. е. при появлении блокера, возможны два варианта. Если объем свободных ресурсов не меньше требуемого дополнительного объема, т. е. разницы между требованиями, то сессия продолжает свое обслуживание, при этом суммарный объем занятого ресурса в системе увеличивается на величину разницы между требованиями. Если объем свободных ресурсов не достаточен, то сессия, попавшая в условия $\mathrm{nLoS}$ блокировки прямой видимости, сбрасывается, занятый ее обслуживанием ресурс освобождается, уменьшая суммарный объем занятого ресурса в системе.

Основной интересующей метрикой является вероятность $\pi_{O}$ преждевременного завершения принятой на обслуживание сессии (далее - вероятность сброса принятой сессии). Сброс сессии означает для пользователя сети досрочное прекра- щение предоставления сетью запрошенной услуги и снижает качество услуг в сети 5G NR [15]. Другой метрикой, которую мы рассматриваем, является вероятность $\pi_{N}$ потери поступающего запроса на установление новой сессии (далее - вероятность потери поступающей сессии). Мы также исследуем влияние доли зарезервированных ресурсов на коэффициент $U$ использования ресурсов системы.

\section{Анализ математической модели}

\section{Формализация и решение системы массового обслуживания}

Рассмотрим систему массового обслуживания (СМО) с сигналами [16] с конечным числом $N$ приборов и ресурсом ограниченного объема $B$. Система обслуживает два типа заявок - новые и повторные. Для оценки влияния механизма резервирования мы вводим два логических пула ресурсов объема $B_{0}$ и $B$, где $B_{0}=\gamma B$ - объем ресурса, доступного для новых и для повторных заявок, $B_{0}<B$, а $(1-\gamma) B-$ объем ресурса, доступного только для повторных заявок. На систему поступает пуассоновский поток новых заявок, который соответствует потоку запросов на установление новой сессии в сети 5G NR. Принятая в систему заявка помимо прибора занимает некоторый случайный объем ресурсов в соответствии с ФР $F_{R}(x)$. В работе $\Phi$ Р $F_{R}(x)$ предполагается дискретной, поэтому далее мы будем говорить о целочисленном ресурсе, например, измеряемом в герцах. Длительность обслуживания заявки имеет экспоненциальное распределение с средним $1 / \mu$. Схема функционирования системы представлена на рис. 2.

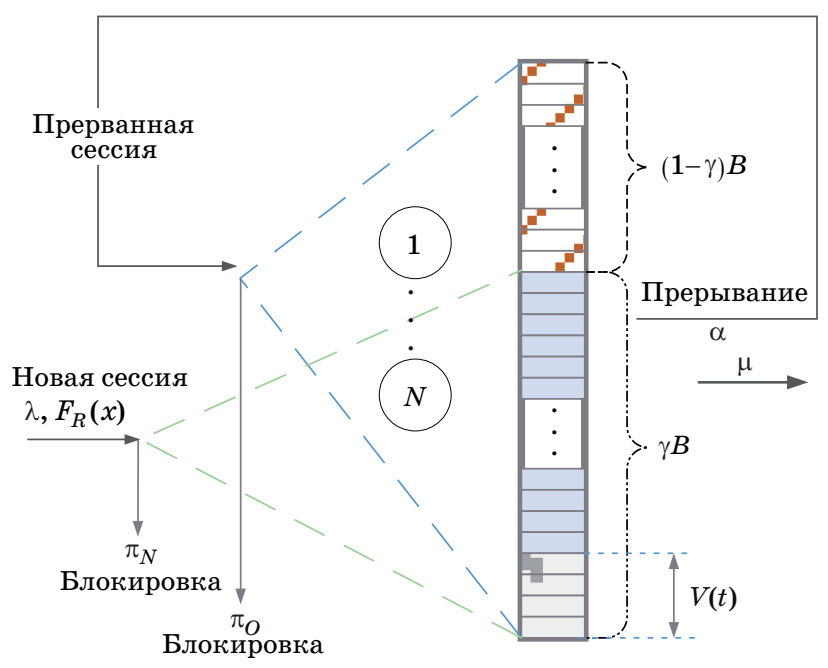

Puc. 2. Ресурсная СМО с сигналами и резервированием

- Fig. 2. Illustration of our queuing model 
Новая заявка принимается, если в общедоступной части $\gamma B$ достаточно свободного ресурса, в противном случае заявка теряется. Также на систему поступает пуассоновский поток сигналов интенсивности $\alpha$. При поступлении сигнала прерывается обслуживание случайно выбранной новой или повторной заявки, и требование к ресурсу для продолжения ее обслуживания разыгрывается заново с той же ФР $F_{R}(x)$. Обслуживание принятой в систему заявки может быть прервано несколько раз. Сигнал прерывания вместо выбранной заявки порождает повторную заявку, которая соответствует той же сессии в сети 5G NR в изменившихся условиях прямой видимости между БС и ПО. Повторной заявке доступен весь свободный ресурс из общего объема ресурса $B$. Если объем запрашиваемого ресурса для повторной заявки больше, чем свободный ресурс, заявка сбрасывается, не завершив обслуживания. При завершении обслуживания заявки или ее сбросе из-за недостатка ресурса для продолжения обслуживания объем занятых ресурсов в системе уменьшается на количество ресурса, которое было ранее выделено для завершенной / сброшенной заявки.

Следуя [16], для вывода стационарного распределения в аналитической замкнутой форме вводим марковский процесс $\mathbf{X}(t)=(\xi(t), \delta(t))$, где $\xi(t)-$ число активных сессий в системе, а $\delta(t)$ - суммарный объем занятых ресурсов [21, 22]. Пространство состояний для процесса $\mathbf{X}(t)$ имеет следующий вид: $\quad \mathbf{X}=\bigcup_{k=1}^{N} \mathbf{X}_{k}, \mathbf{X}_{k}=\left\{(k, r): 0 \leq r \leq B, p_{r}^{(k)}>\mathbf{0}\right\}$, где $p_{r}^{(k)}$ обозначает $k$-кратную свертку вероятно- стей $p_{r}, r \geq 0$, и интерпретируется как вероятность того, что $k$ заявок занимают $r$ единиц ресурса. Стационарные вероятности процесса $\mathbf{X}(t)$ определяются как

$$
\begin{gathered}
q_{0}=\lim _{t \rightarrow \infty} P\{\xi(t)=0, \delta(t)=0\} ; \\
q_{k}(r)=\lim _{t \rightarrow \infty} P\{\xi(t)=k, \delta(t)=r\},(k, r) \in \mathbf{X}_{k} .
\end{gathered}
$$

Заметим, что если требованиек ресурсу повторной заявки не превышает количество свободного ресурса, система меняет свое состояние с $(k, j)$ на $(k, r)$ с вероятностью $\sum_{j=0}^{\min (j, r)} p_{j-i} p_{i}^{(k-1)} p_{r-i} / p_{j}^{(k)}$. В противном случае повторная заявка сбрасывается, и система переходит из состояния $(k+1, r+j)$ в $(k, r)$ с вероятностью $\left(1-\sum_{s=0}^{B-r} p_{s}\right) p_{j} p_{r}^{(k)} / p_{j+r}^{(k+1)}$.

Диаграмма интенсивностей переходов для центральных состояний системы представлена на рис. 3.

Система уравнений равновесия для процесса $\mathbf{X}(t)$ имеет следующий вид:

$$
\begin{gathered}
\lambda q_{0} \sum_{j=0}^{B_{0}} p_{j}=\mu \sum_{j:(1, j) \in \mathbf{X}_{1}} q_{1}(j)+\alpha \sum_{j:(1, j) \in \mathbf{X}_{1}} q_{1}(j)\left(1-\sum_{j=0}^{B} p_{j}\right) \\
\left(\theta\left(B_{0}-j\right) \lambda \sum_{j=0}^{B_{0}-r} p_{j}+k \mu+k \alpha\right) q_{k}(r)= \\
=\theta\left(B_{0}-j\right) \lambda \sum_{j \geq 0:(k-1, r-j) \in \mathbf{X}_{k-1}} q_{k-1}(r-j) p_{j}+
\end{gathered}
$$

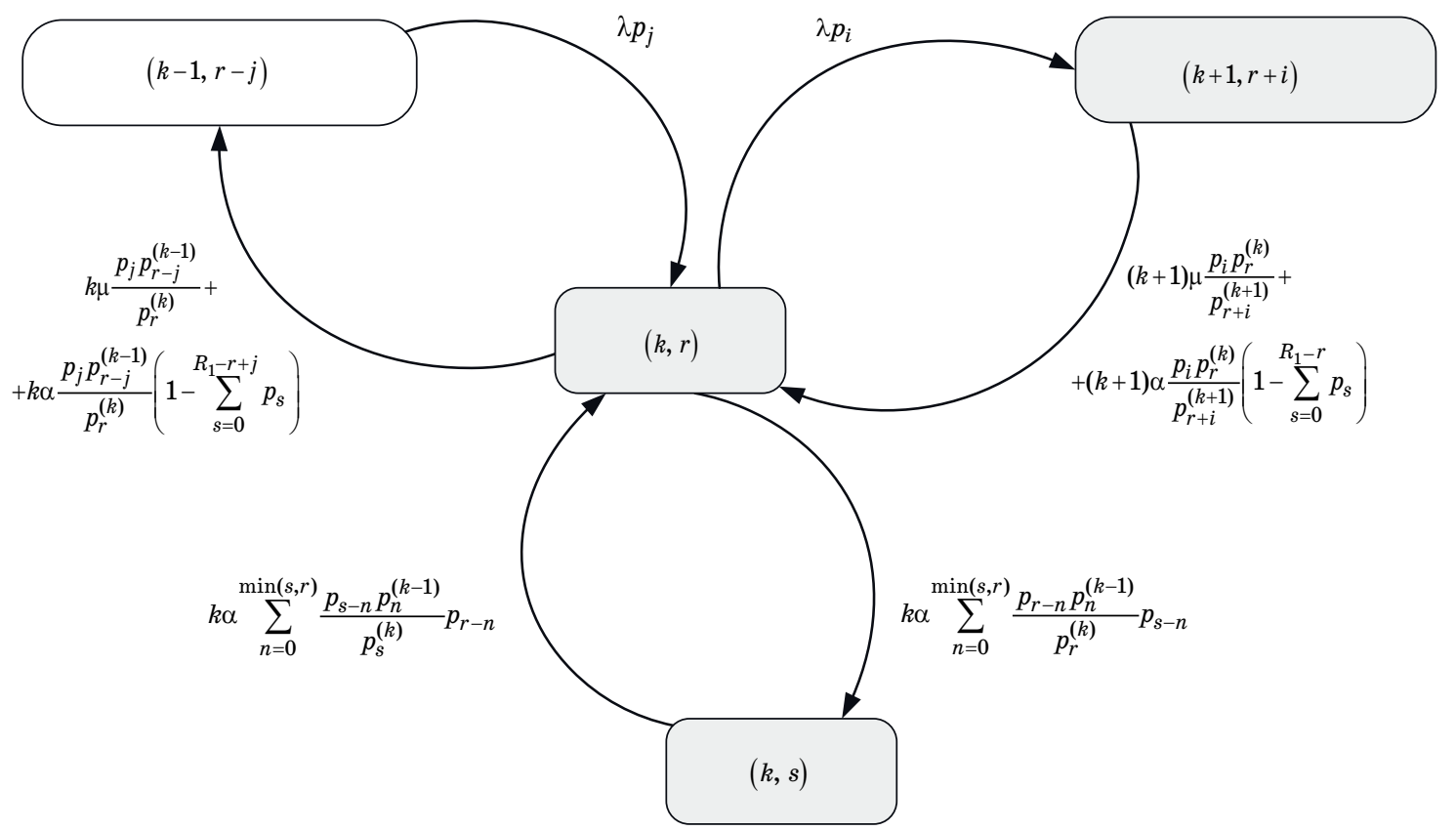

- Puc. 3. Диаграмма интенсивностей переходов

- Fig. 3. Illustration of transition rates in the Markov model 


$$
\begin{aligned}
& +(k+1) \mu \sum_{j \geq 0:(k+1, r+j) \in X_{k+1}} q_{k+1}(r+j) \frac{p_{j} p_{r}^{(k)}}{p_{j+r}^{(k+1)}}+ \\
& +(k+1) \alpha\left(1-\sum_{j=0}^{B-r} p_{j}\right) \times \\
& \times \sum_{j \geq 0:(k+1, r+j) \in \mathbf{X}_{k+1}} q_{k+1}(r+j) \frac{p_{j} p_{r}^{(k)}}{p_{j+r}^{(k+1)}}+k \alpha \times \\
& \times \sum_{j \geq 0: j:(k, j) \in \mathbf{X}_{k}} q_{k}(j) \sum_{i=0}^{\min (j, r)} \frac{p_{j-i} p_{i}^{(k-1)}}{p_{j}^{(k)}} p_{r-i} ; \\
& =\theta\left(B_{0}-j\right) \lambda \sum_{j \geq 0:(N-1, j) \in \mathbf{X}_{N-1}} q_{N-1}(r-j) p_{j}+ \\
& +N \alpha \sum_{j:(N, j) \in \mathbf{X}_{N}}^{B} q_{N}(j) \sum_{i=0}^{\min (j, r)} \frac{p_{j-i} p_{i}^{(N-1)}}{p_{j}^{(N)}} p_{r-i} .
\end{aligned}
$$

Здесь $(N, r) \in \mathbf{X}_{k}, 1 \leq k \leq N-1,(k, r) \in \mathbf{X}_{k}$, а $\theta\left(B_{0}-j\right)-$ функция Хевисайда:

$$
\theta\left(B_{0}-j\right)=\left\{\begin{array}{l}
0, j>B_{0} \\
1, j \leq B_{0}
\end{array}\right.
$$

Зная стационарные вероятности состояний системы, можно получить вероятностные характеристики СМО, представляющие интерес: вероятности потери новой заявки и сброса повторной заявки, соответствующие вероятностям потери поступающей сессии и сброса принятой на обслуживание сессии в сети 5G NR, а также коэффициент использования ресурса CMO, соответствующий коэффициенту использования ресурсов БC.

В частности, формула для вычисления вероятности потери новой заявки имеет вид

$$
\pi_{N}=1-\sum_{n=0}^{N-1} \sum_{r=0}^{B_{0}} q_{n}(r) \sum_{j=0}^{B_{0}-r} p_{j} .
$$

Для получения формулы вероятности сброса повторной заявки необходимо ввести следующие обозначения. Пусть $T-$ некоторый достаточно большой интервал времени и $\lambda\left(1-\pi_{N}\right)-$ ин- $^{-}$ тенсивность поступления новых заявок. Тогда $\lambda\left(1-\pi_{N}\right) T-$ среднее число новых заявок, принятых на обслуживание за время $T$. Среднее число заявок в системе определяется как

$$
E[N]=\sum_{n=0}^{N} \sum_{r=0}^{B} n q_{n}(r)
$$

Тогда $\alpha E[N]$ является интенсивностью прерывания, а интенсивность сброса заявки определяется как

$$
\beta=\alpha E[N] \sum_{n=1}^{N} \sum_{r=0}^{B} q_{n}(r) \sum_{j=0}^{r} \frac{p_{j} p_{r-j}^{(n-1)}}{p_{r}^{(n)}}\left[1-\sum_{i=0}^{B-r+j} p_{i}\right] .
$$

Используя (7), получаем вероятность сброса повторной заявки

$$
\pi_{O}=\lim _{T \rightarrow \infty} \frac{\beta T}{\lambda\left(1-\pi_{N}\right) T}=\frac{\beta}{\lambda\left(1-\pi_{N}\right)} .
$$

Наконец, коэффициент использования ресурса оцениваем как отношение среднего суммарного занятого ресурса в стационарном режиме к общему ресурсу системы:

$$
U=\frac{1}{B} \sum_{n=1}^{N} \sum_{r=0}^{B} r q_{n}(r)
$$

\section{Параметризация СМО}

Для проведения анализа показателей производительности системы, определенных формулами (5)-(9), необходимо выполнить параметризацию системы, в частности, определить $\Phi \mathrm{P} F_{R}(x)$ объема запрашиваемого для обслуживания сессии ресурса и интенсивность $\alpha$ поступления сигналов прерываний, соответствующих переходам из условий $\mathrm{LoS}$ в $\mathrm{nLoS}$ и обратно.

Прежде всего, найдем радиус $d_{E}$ зоны покрытия БС. Зона покрытия определяется таким образом, что мощность сигнала между БС и ПО, находящимся на границе зоны в условиях $\mathrm{nLoS}$ отсутствия прямой видимости, равна пороговому уровню мощности для предоставления запрошенной услуги. Обозначим $S_{\min }$ пороговое значение ОСШ, соответствующее «младшей» модуляционно-кодовой схеме, определенной для NR [2]. Моделируя распространение сигнала с помощью формулы Фрииса [17] с учетом условий $\mathrm{nLoS}$, имеем следующее соотношение:

$$
S_{\min }=\frac{P_{A} G_{A} G_{U}}{N_{0} W A_{2}}\left(d_{E}^{2}+\left[h_{A}-h_{U}\right]^{2}\right)^{-\zeta / 2},
$$

где $P_{A}-$ мощность БС; $G_{A}, G_{U}-$ коэффициенты усиления антенн БС и ПО [20]; $N_{0}$ - тепловой шум на 1 Гц (постоянная Джонсона - Найквиста); $W$ - полоса, Гц; $A_{2}=10^{2 \log _{10} f_{c}+4,24}-$ коэффициент распространения сигнала в условиях $\mathrm{nLoS} ; h_{A}$ и $h_{U}-$ высоты БС и ПО; $\zeta$ - экспонента затухания.

Решая уравнение относительно $d_{E}$, получаем

$$
d_{E}=\sqrt{\left(P_{A} G_{A} G_{U} /\left(N_{0} W A_{2} S_{\min }\right)\right)^{2 / \zeta}-\left(h_{A}-h_{U}\right)^{2}} .
$$


Имея значение $d_{E}$, мы можем определить функцию распределения требований к ресурсам при установлении / поддержании сессии. Пусть $S_{n B}$ - случайная величина, обозначающая ОСШ в условиях LoS прямой видимости, а $F_{S_{n B}}(x)$, $x>0$ - ее ФР. Учитывая равномерное распределение генерирующих запросы на новые сессии ПО в пределах покрытия БС, $Ф$ Р $F_{D}(y)$ расстояния $D$ между ПО и БС может быть записана как

$$
\begin{gathered}
F_{D}(y)=\left(y^{2}-\left(h_{A}-h_{U}\right)^{2}\right) / d_{E}^{2} \\
\left|h_{A}-h_{U}\right|<y<\sqrt{d_{E}^{2}+\left(h_{A}-h_{U}\right)^{2}} .
\end{gathered}
$$

Поскольку модель распространения является монотонно убывающей функцией, распределение ОСШ в условиях LoS может быть выражено через распределение расстояния $D$, т. е. $F_{S_{n B}}(s)=1-F_{D}\left(\sqrt[\zeta]{P_{A} G_{A} G_{U} /\left(N_{0} W A_{1} s\right)}\right)$, где $A_{1}=$ $=10^{2 \log _{10} f_{c}+3,24}$.

Функция распределения случайной величины $S_{B}$, определяющая ОСШ в условиях nLoS, получается аналогично. Для определения общей ФР ОСШ нам также требуется вероятность блокировки прямой видимости. В работе [7] вероятность блокировки прямой видимости для ПО, находящегося на расстоянии $x$, определяется как $\pi_{B}(x)=1-e^{-2 \lambda_{B} r_{B}\left(x \frac{h_{B}-h_{U}}{h_{A}-h_{U}}+r_{B}\right)}$, откуда следует, что $\pi_{B}=\int_{0}^{d_{E}} p_{B}(x) \frac{2 x}{d_{E}^{2}} \mathrm{~d} x$.

Функцию распределения ОСШ $F_{S}(s), s>0$, теперь можно определить путем взвешивания случайных величин $S_{B}$ и $S_{n B}$, соответствующих условиям nLoS и LoS, с вероятностями $\pi_{B}$ и $1-\pi_{B}$ соответственно. Обозначим далее $s_{j}, j=1,2, \ldots, K$ границы диапазонов ОСШ для модуляционно-кодовых схем MCS NR, определенных в [2], где $K-$ число таких схем. Тогда вероятность $m_{i}$ того, что для сессии ПО назначена модуляционно-кодовая схема $i$, имеет вид

$$
m_{i}=F_{S}\left(s_{i+1}\right)-F_{S}\left(s_{i}\right)
$$

Поскольку скорость передачи данных для каждой модуляционно-кодовой схемы известна [2], зная пространственное распределение ПО, с помощью (13) мы можем оценить объем ресурса, требуемый для поддержания сессии с заданной средней скоростью передачи данных $R$. Таким образом, получаем $\Phi \mathrm{P} F_{R}(x)$ объема запрашиваемых ресурсов для модели СМО из первого раздела.

Осталось определить параметр $\alpha$ - интенсивность изменения условий прямой видимости для ПО. Для этого сначала мы определяем интенсивность $\varepsilon(x)$ пересечения блокерами зоны блокировки прямой видимости для пользователя, расположенного на расстоянии $x$ от БС. На рис. $4, a$ эта прямоугольная зона показана серым фоном, а на рис. 4, б показаны семь областей вокруг зоны блокировки, двигаясь из которых блокеры могут пересекать зону блокировки, перекрывая прямую видимость между ПО и БС. Интенсивность блокеров, пересекающих зону блокировки ПО, может быть аппроксимирована следующим образом:

$$
\varepsilon(x)=\sum_{i=1}^{7} \iint_{M_{i}} g_{i}(x, y) P\{E\} P\{T>1\} \lambda_{B} M_{i} \mathrm{~d} x \mathrm{~d} y,
$$

где $M_{i}$ - площадь области $i ; g_{i}(x, y)-$ плотность вероятности нахождения блокера в точке $(x, y)$ в области $i ; P\{E\}$ - вероятность того, что блокер движется в направлении зоны блокировки; $P\{T>1\}-$ вероятность того, что блокер не меня- a)

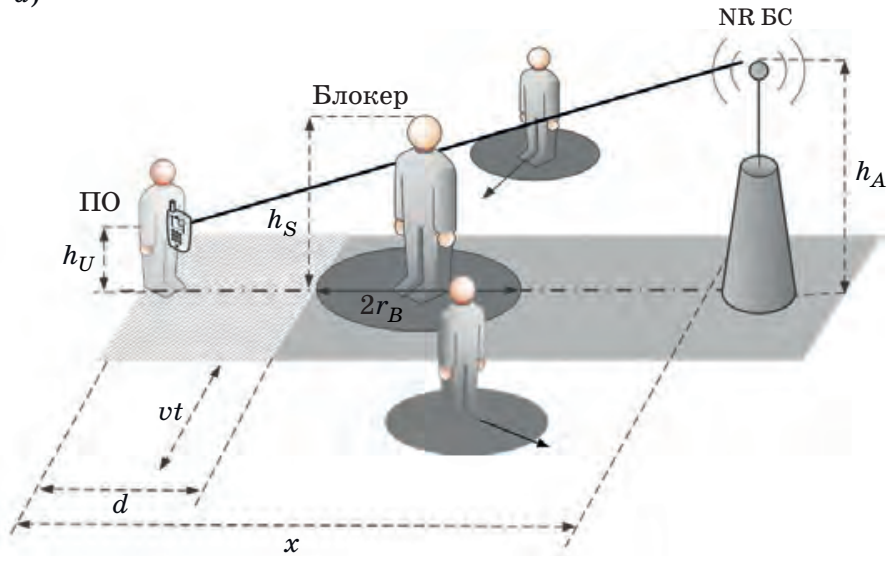

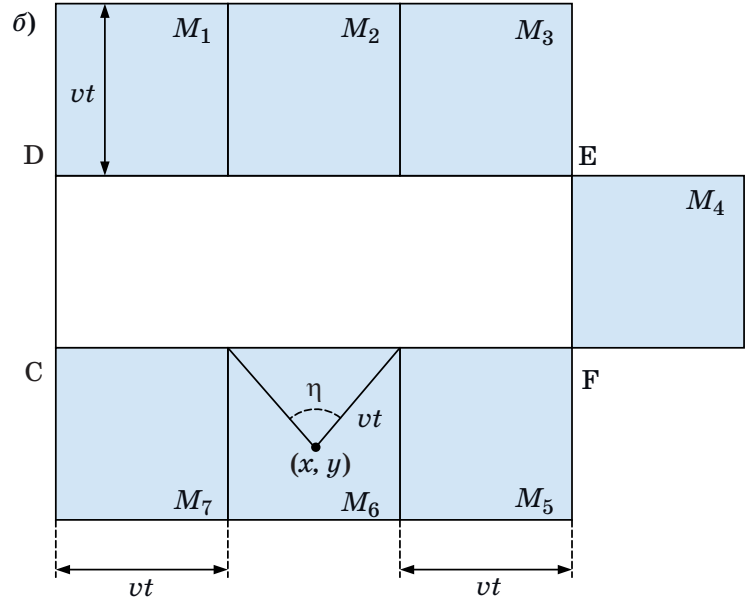

- Puc. 4. Зона блокировки прямой видимости ПО: $a$ - модель движения блокера; $б$ - источники блокеров

- Fig. 4. UE blocking zone: $a-$ blocker movement model; $\sigma-$ sources of blockers 
ет направление своего движения в течение единицы времени.

Заметим, что $g_{i}(x, y)=1 / M_{i} ; P\{T>1\}=\exp (-1 / \tau)$; $P\{E\}=\eta_{i}(x, y) / 2 \pi$, где $\eta_{i}(x, y)$ - диапазон угла направления движения блокера в области $i$, который приведет к пересечению зоны блокировки прямой видимости.

Теперь мы можем упростить выражение (14) следующим образом:

$$
\varepsilon(x)=\frac{\lambda e^{-1 / \tau}}{2 \pi} \sum_{i=1}^{7} \iint_{M_{i}} \eta_{i}(x, y) \mathrm{d} x \mathrm{~d} y,
$$

где $\eta_{i}(x, y)=\left(\left[x_{D}-x\right] / v t\right), i=1,3,5,7 ; \eta_{i}(x, y)=$ $=2 \cos ^{-1}\left(\left[x_{E}-x\right] / v t\right), i=2,6 ; \quad \eta_{4}(x, y)=2 \tan ^{-1} \times$ $\times\left(\left[x-x_{E}\right] /\left[y-y_{E}\right]\right)$.

Окончательно нормированная по времени интенсивность поступления блокеров в зону блокировки прямой видимости в зоне покрытия БС имеет вид

$$
\varepsilon=\int_{0}^{d_{E}} \varepsilon(x) \frac{2 x}{d_{E}^{2}} \mathrm{~d} x
$$

Формула (15) определяет параметр экспоненциального распределения длительности интервала LoS прямой видимости между ПО и БС [18]. Длительность интервала nLoS блокировки прямой видимости между ПО и БС соответствует периоду занятости в CMO $M|G I| \propto$, где ФР времени обслуживания, которое представляет собою время пребывания блокера в зоне блокировки, зависит от модели движения блокера [19]. Тогда параметр $\alpha$ - интенсивность изменения условий прямой видимости для ПО - может быть получен как обратная величина к среднему интервалов LoS и nLoS.

\section{Численные результаты и их интерпретация}

В данном разделе приведены результаты численного анализа применения механизма резервирования ресурсов БC 3GPP NR для сессий, принятых на обслуживание. В качестве показателей эффективности мы используем вероятность потери запроса на установление сессии и вероятность сброса принятой на обслуживание сессии, а также коэффициент использования ресурса БС. Значения параметров системы для численного анализа приведены в таблице.

Заметим, что нагрузка в системе зависит от площади зоны покрытия NR БС. Для параметризации модели мы выбрали интенсивность $\lambda$ поступления запросов на установление сессии на квадратный метр, которая указана на графиках рис. 5 и 6 . Также отметим, что расчеты для различных
Исходные данные для численного анализа

\begin{tabular}{|c|c|}
\hline Параметр & Значение \\
\hline Несущая частота, $f_{c}$ & 28 Гц \\
\hline Полоса частот, $B$ & 400 МГц \\
\hline Высота БС, $h_{A}$ & $10 \mathrm{~m}$ \\
\hline Высота блокера, $h_{B}$ & $1,7 \mathrm{M}$ \\
\hline Высота ПО, $h_{U}$ & $1,5 \mathrm{M}$ \\
\hline Радиус блокера, $r_{B}$ & $0,4 \mathrm{M}$ \\
\hline $\begin{array}{l}\text { Скорость перемещения } \\
\text { блокера, } v\end{array}$ & $2 \mathrm{M} / \mathrm{c}$ \\
\hline $\begin{array}{l}\text { Среднее перемещение блокера } \\
\text { за такт, } \tau\end{array}$ & $5 \mathrm{M}$ \\
\hline Мощность передатчика, $P_{T}$ & $0,2 \mathrm{~B}$ T \\
\hline Экспонента затухания, $\zeta$ & 2,1 \\
\hline Плотность блокеров, $\lambda_{B}$ & 0,5 на $1 \mathrm{~m}^{2}$ \\
\hline Тепловой шум, $N_{0}$ & -84 дБм \\
\hline Затухание сигнала & 15 дБ \\
\hline Антенная решетка ПО & $4 \times 4$ элементов \\
\hline Усиление антенны ПО, $G_{R}$ & 5,57 дБи \\
\hline $\begin{array}{l}\text { Средняя скорость передачи } \\
\text { данных, } R\end{array}$ & 2, 5, 10 Мбит/с \\
\hline $\begin{array}{l}\text { Среднее время обслуживания } \\
\text { сессии, } 1 / \mu\end{array}$ & $30 \mathrm{c}$ \\
\hline $\begin{array}{l}\text { Интенсивность поступления } \\
\text { сессий на БС, } \lambda\end{array}$ & $10^{-4}, 10^{-2}$ сессий/с \\
\hline Число антенных элементов БС & $\begin{array}{l}1,4,8,16,32,64, \\
128\end{array}$ \\
\hline $\begin{array}{l}\text { Доля общедоступного ресурса, } \\
\gamma\end{array}$ & {$[0,8 ; 1]$} \\
\hline
\end{tabular}

Default parameters for numerical assessment

конфигураций антенных решеток не показали качественного изменения поведения исследуемых характеристик, поэтому ниже приведены результаты для одного из вариантов, а именно антенной решетки $4 \times 4$ на стороне ПО. Схемы MCS для NR были взяты из публикации [2].

Вероятности потери поступающей сессии и вероятности сброса принятой на обслуживание сессии в зависимости от параметра $\gamma$ механизма резервирования ресурсов показаны на рис. 5 для средней скорости передачи данных 2 Мбит/с, интенсивности поступления запросов на установление сессии, равной $2,2 \cdot 10^{-8}$ на квадратный метр, и плотности блокеров, равной 0,04 на квадратный метр. На рис. 5, $a$ можно заметить, что механизм резервирования ресурсов позволяет сократить сброс сессий, принятых на обслуживание. Как и ожидалось, существует баланс между вероятностями потери поступающей сессии и сброса 

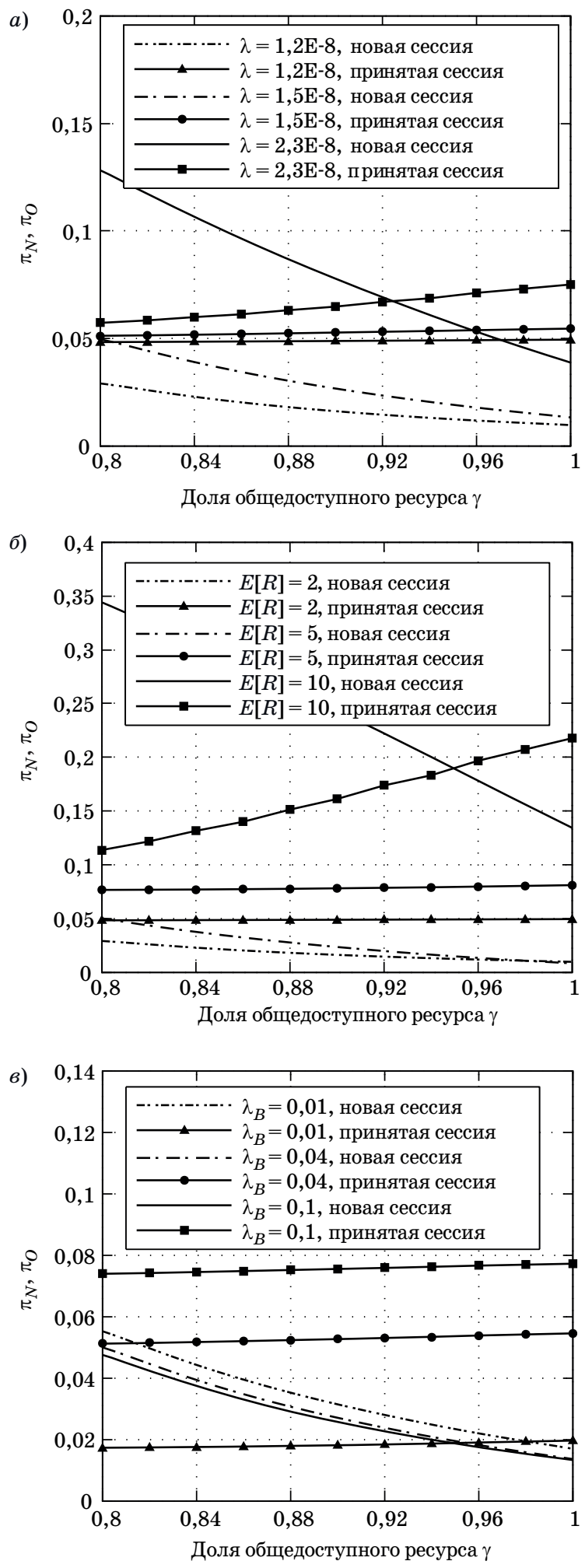

Puc. 5. Вероятности потери поступающей сессии и сброса принятой сессии: $a-$ интенсивность поступления запросов на установление сессии; б - средняя скорость передачи данных; $в$ - плотность блокеров

- Fig. 5. New and ongoing session drop probabilities for selected system parameters: $a$ - the intensity of requests to establish a session; $\sigma$ - average data rate; $8-$ blocker density принятой на обслуживание сессии. Тем не менее преимущества предлагаемого метода очевидны для всех рассмотренных интенсивностей поступления запросов на установление сессии. Важно отметить положительный эффект применения механизма резервирования с точки зрения вероятности сброса принятых на обслуживание сессий при увеличении интенсивности поступления запросов на установление новой сессии, что обеспечивает более высокую производительность системы именно в условиях перегрузки. Последнее имеет решающее значение для потенциальных операторов сетей $5 \mathrm{G}$ NR.

Рассмотрим влияние скорости $R$ передачи данных, представленное на рис. 5 , б, для интенсивности поступления запросов на установление сессии, равной $2,2 \cdot 10^{-8}$ на квадратный метр, и плотности блокеров 0,04 на квадратный метр. Здесь наблюдаются несколько важных эффектов. Во-первых, увеличение средней скорости передачи данных отрицательно влияет на вероятность потери поступающей сессии и, напротив, положительно - на вероятность сброса сессии, принятой на обслуживание. Во-вторых, что более важно, в ответ на растущие требования к скорости передачи данных преимущество резервирования ресурсов резко возрастает. В частности, для средней скорости 10 Мбит/с вероятность сброса принятой сессии при резервировании $20 \%$ ресурса для принятых на обслуживание сессий уменьшается в два раза с 0,21 для $\gamma=1$ до 0,11 при $\gamma=0,8$. Для тех же значений $\gamma$ и $E[R]=5$ Мбит/с разница практически не увеличивается. Следовательно, резервирование ресурсов особенно эффективно для сессий, имеющих высокие требования к скорости передачи данных. Обслуживание таких сессий является основной задачей будущих систем $5 \mathrm{G}$ NR.

Известно, что блокировки прямой видимости серьезно влияют на производительность систем NR, работающих в миллиметровом диапазоне частот. На рис. 5, в показано влияние плотности блокеров на вероятности потери поступающей сессии и сброса принятой сессии для скорости передачи данных 2 Мбит/с и интенсивности поступления запросов на установление сессии, равной $2,2 \cdot 10^{-8}$ на квадратный метр. Несложно заметить существенную разницу между вероятностями сброса принятой сессии, соответствующими разным значениям плотности блокеров. Фактически вероятность $\pi_{O}$ увеличивается от 0,02 до 0,07-0,08. Разница же в вероятностях потери поступающей сессии намного меньше и не превышает 0,01 во всем рассматриваемом диапазоне. Причиной такого поведения является то, что более высокие значения плотности блокеров приводят к более высокой интенсивности изменения условий прямой видимости между БС и ПО. Рост числа переходов между состояниями LoS/ 
nLoS для ПО в течение обслуживания одной сессии приводит к увеличению вероятности сброса принятой сессии. Заметим, что такой же эффект дает увеличение высоты БС или блокера, а также уменьшение высоты ПО, что увеличивает зону блокировки LoS, тем самым приводя к более частым изменениям условий прямой видимости для ПО.

Механизм резервирования ресурсов предназначен для достижения баланса между вероятностями потери поступающей сессии и сброса принятой сессии. Заметим, что резервирование ресурсов для сессий, уже принятых в систему, может поставить под угрозу эффективность использования ресурсов. Использование ресурсов сети в зависимости от интенсивности поступления новых сессий проиллюстрировано на рис. 6 при средней скорости передачи данных 2 Мбит/с и плотности блокеров 0,04 на квадратный метр. Ожидаемо, что при росте $\lambda$ увеличивается объем используемых ресурсов во всем рассматриваемом диапазоне резервирования. В частности, для более низких значений, например для интенсивности поступления запросов на установление сессии, равной $1,2 \cdot 10^{-8}$, коэффициент использования ресурсов остается практически неизменным, 0,26 при $\gamma \in[0,8 ; 1]$. Для более высоких значений интенсивности поступления запросов на установление сессий, для которых резервирование ресурсов показало высокую эффективность на стороне пользователя (см. рис. 5), ухудшение составляет от 0,73 для $\gamma=1$ до 0,65 для $\gamma=0,8$. Причиной такого эффекта являются частые изменения условий прямой видимости ПО для сессий, принятых на обслуживание.

Влияние средней скорости передачи данных на коэффициент использования ресурсов показано на рис. 6, б для двух предложенных интенсивностей поступления сессий и плотности блокеров, равной 0,04 на квадратный метр. Следует заметить, что снижение коэффициента использования ресурсов незначительно для всех рассмотренных скоростей передачи данных. Однако важно отметить, что при более высоких скоростях коэффициент использования ресурсов увеличивается. Причина такого поведения в следующем: во-первых, улучшение частично связано с более высокой предложенной нагрузкой $\rho=E[R] \lambda / \mu$, во-вторых, сессии с большей средней скоростью характеризуются высокими требованиями к ресурсам в условиях $\mathrm{nLoS}$.

Наконец, рассмотрим влияние плотности блокеров на коэффициент использования ресурсов (рис. 6, в) при средней скорости 2 Мбит/с и интенсивности поступления запросов на установление сессий, равной $1,5 \cdot 10^{-8}$ на квадратный метр. Мы наблюдаем, что увеличение $\lambda_{B}$ приводит $\kappa$ незначительному снижению использования ре- a)

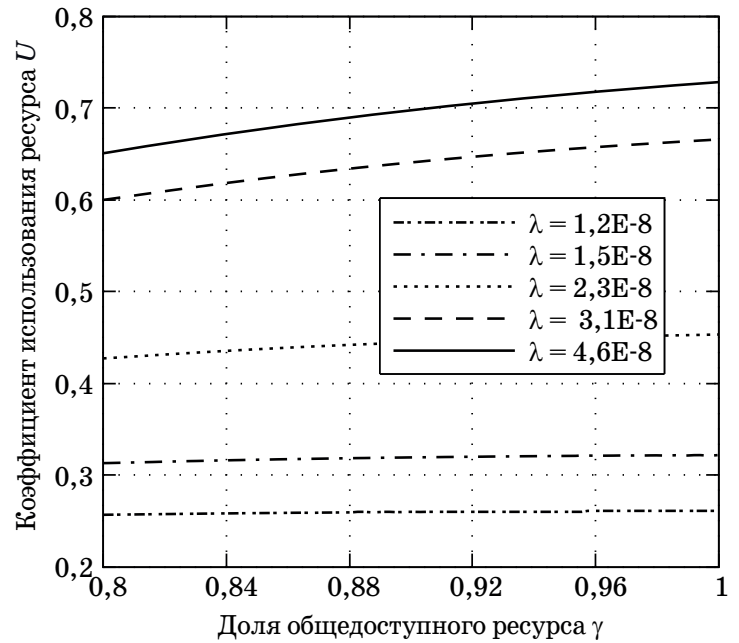

б)

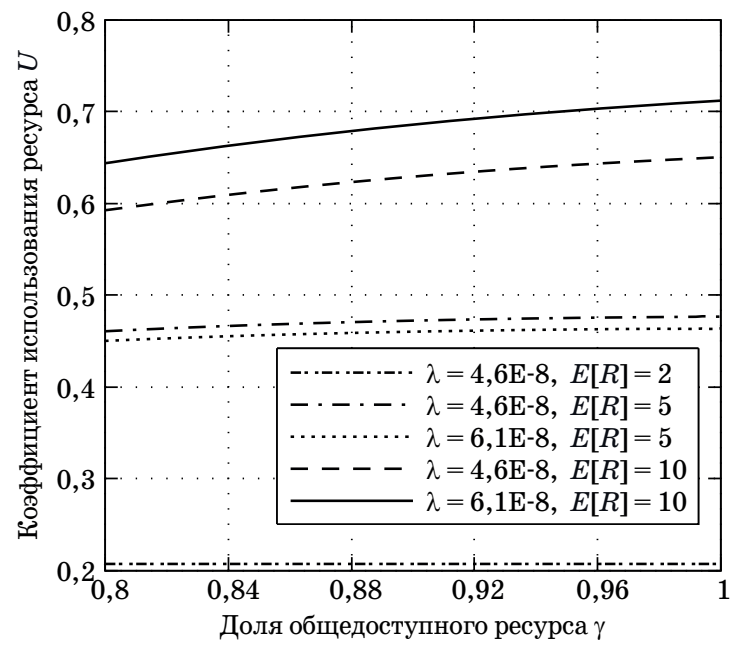

в)

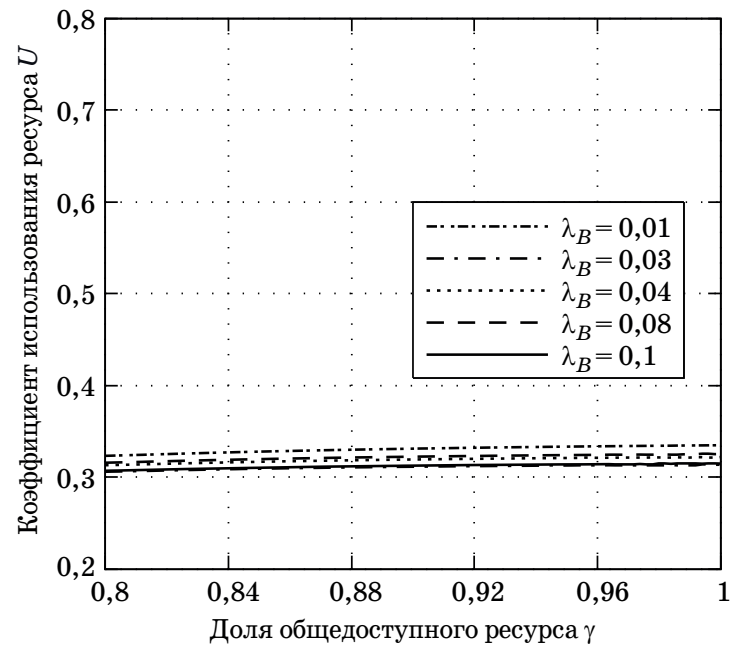

Puc. 6. Коэффициент использования ресурсов: $a-$ интенсивность поступления запросов на установление сессии; б - средняя скорость передачи данных; в плотность блокеров

- Fig. 6. System resource utilization as a function of system parameters: $a$ - the intensity of requests to establish a session; $\sigma-$ average data rate; 6 - blocker density 
сурсов во всем диапазоне значений параметра механизма резервирования. Основная причина заключается в том, что высокая интенсивность изменений условий прямой видимости для ПО приводит к большому количеству прерываний соответствующей сессии, что было видно также на рис. 5, в, причем ключевым параметром здесь является отношение между средней длительностью обслуживания сессии и частотой изменения условий прямой видимости.

\section{Заключение}

В системах 3GPP NR частые блокировки прямой видимости между приемо-передающими устройствами могут привести к сбросу уже принятых в систему сессий, обслуживание которых не завершено. В статье предложен механизм резервирования ресурса БС в целях повышения качества предоставления услуг в системах 3GPP NR, а также разработана математическая модель, позволяющая исследовать влияние этого механизма на основные показатели качества обслуживания в сети 5G NR - непрерывность сессий и отказ в установлении новой сессии. Модель учитывает ключевые особенности технологии 3GPP NR, включая высоту взаимодействующих объектов, геометрию и мобильность блокеров, миллиметровый диапазон передачи, модуляционно-кодовые схемы, антенные решетки, а также прямую видимость между приемо-передающими устройствами.

Численный анализ показал, что создание приоритета для сессий, чье обслуживание еще не за-

\section{Литература}

1. Report ITU-R M.2376-0: Technical feasibility of IMT in bands above $6 \mathrm{GHz}$. ITU, Electronic Publication, Geneva, 2015. https:/www.itu.int/dms_pub/itu-r/ opb/rep/R-REP-M.2376-2015-PDF-E.pdf (дата обращения: 15.05.2019).

2. 3rd Generation Partnership Project: Technical Specification Group Radio Access Network, NR, Physical channels and modulation (Release 15), 3GPP TR 38.211, V15.6.0, 2019. https://www.3gpp.org/ftp/ Specs/archive/38_series/38.211/ (дата обращения: 10.06.2019).

3. Report Qualcomm: Making 5G NR a Commercial Reality, 2019. https://www.qualcomm.com/media/documents/files/making-5g-nr-a-commercial-reality.pdf (дата обращения: 15.05.2019).

4. Татарникова Т. М. Статистические методы исследования сетевого трафика. Инфорлационно-управляющие систелы, 2019, № 5, с. 35-43. https://doi. org/10.31799/1684-8853-2018-5-35-43 вершено, обеспечивает значительную гибкость для балансировки непрерывности сессии и отказа в установлении новой сессии за счет небольшого снижения эффективности использования радиоресурса. На практике резервирование небольшого количества радиоресурсов для сессий, принятых на обслуживание, может значительно повысить непрерывность сессий в системе. Важно отметить, что свои лучшие показатели система демонстрирует в условиях перегрузки. Кроме того, для любого заданного значения параметра механизма резервирования вероятность сброса обслуживаемой сессии уменьшается с увеличением средней скорости передачи данных в течение сессии. Эти особенности повышают востребованность предложенного механизма для систем NR, которые в первую очередь предназначены для приложений, требующих высокой пропускной способности.

\section{Благодарности}

Авторы благодарят аспиранта кафедры прикладной информатики и теории вероятностей РУДН Т. Р. Велиеву, принимавшую участие в проведении численного эксперимента, за оформление его результатов.

\section{Финансовая поддержка}

Исследование выполнено при финансовой поддержке Министерства образования и науки Российской Федерации (проект 2.882.2017/4.6).

5. Галинина О. С., Андреев С. Д., Тюрликов А. М. Учет специфики доступа большого числа устройств при межмашинном взаимодействии в современных сотовых сетях. Инфорлационно-управляющие системы, 2019, № 4, с. 105-114. https://doi.org/10. 31799/1684-8853-2019-4-105-114

6. Samuylov A., Gapeyenko M., Moltchanov D., Gerasimenko M., Singh S., Himayat N., Andreev S., and Koucheryavy Y. Characterizing spatial correlation of blockage statistics in urban mmWave systems. 2016 IEEE Globecom Workshops (GC Wkshps), 2016, pp. 1-7. https://doi. org/10.1109/GLOCOMW.2016.7848859

7. Gapeyenko M., Samuylov A., Gerasimenko M., Moltchanov D., Singh S., Akdeniz M., Aryafar E., Himayat N., Andreev S., and Koucheryavy Y. On the temporal effects of mobile blockers in urban millimeter-wave cellular scenarios. IEEE Transactions on Vehicular Technology 66, 2017, no. 11, pp. 1012410138. doi:10.1109/TVT.2017.2754543

8. Michalopoulos D. S., Viering I., and Du L. User-plane multiconnectivity aspects in 5G. 2016 23rd Interna- 
tional Conference on Telecommunications (ICT), May 2016, pp. 1-5.

9. Ohmann D., Awada A., Viering I., Simsek M., and Fettweis G. P. Achieving high availability in wireless networks by inter-frequency multi-connectivity. 2016 IEEE International Conference on Communications (ICC), May 2016, 7 p. doi:10.1109/ICC.2016.7511428

10. 3rd Generation Partnership Project: NR, Multi-connectivity; Overall description; Stage-2 (Release 15), 3GPP TR 37.340, December 2017. https://www.3gpp. org/ftp/Specs/archive/37_series/37.340/ (дата обращения: 23.04.2019).

11. Giordani M., Mezzavilla M., and Zorzi M. Initial access in $5 \mathrm{G}$ mmwave cellular networks. IEEE Communications Magazine, Nov. 2016, vol. 54, pp. 40-47.

12. Moltchanov D., Samuylov A., Petrov V., Gapeyenko M., Himayat N., Andreev S., and Koucheryavy Y. Improving session continuity with bandwidth reservation in mmwave communications. IEEE Wireless Communications Letters 8, 2019, no. 1, pp. 105-108. doi:10.1109/LWC.2018.2859988

13. Kingman J. F. C. Poisson processes. Wiley Online Library, 1993. 112 p. doi.org/10.1002/0470011815. b2a07042

14. Nain P., Towsley D., Liu B., and Liu Z. Properties of random direction models. IEEE 24th Annual Joint Conference of the IEEE Computer and Communications Societies, 2005, vol. 3, pp. 1897-1907. doi:10.1109/INFCOM.2005.1498468
15. Seitz N. ITU-T QoS standards for IP-based networks. IEEE Communications Magazine, 2003, vol. 41, no. 6 , pp. $82-89$.

16. Наумов В. А., Самуйлов К. Е. Анализ сетей ресурсных систем массового обслуживания. Автолати ка и телелеханика, 2018, вып. 5, с. 59-68. doi.org/ $10.1134 / \mathrm{S} 0005117918050041$

17. Friis H. T. A note on a simple transmission formula. Proceedings of the IRE, 1946, vol. 34(5), pp. 254-256. doi:10.1109/JRPROC.1946.234568

18. Gapeyenko M., Samuylov A., Gerasimenko M., Moltchanov D., Singh S., Aryafar E., Yeh S., Himayat N., Andreev S., and Koucheryavy Y. Analysis of human-body blockage in urban millimeter-wave cellular communications. 2016 IEEE International Conference on Communications (ICC), 2016, 7 p. doi:10.1109/ICC.2016.7511572

19. Daley D. J. and Servi L. Idle and busy periods in stable $\mathrm{m} / \mathrm{m} / \mathrm{k}$ queues. Journal of Applied Probability, 1988, vol. 35 (4), pp. 950-962.

20. Constantine A. B., et al. Antenna theory: analysis and design. Microstrip Antennas. Third edition. John Wiley \& Sons, 2005. 1099 p.

21. Bobbio A. and Trivedi K. S. An aggregation technique for the transient analysis of stiff markov chains. IEEE Transactions on Computers, 1986, no. 9 , pp. 803-814.

22. Ciardo G. and Smirni E. Etaqa: an efficient technique for the analysis of qbd-processes by aggregation. Performance Evaluation, 1999, vol. 36, pp. 71-93.

\section{UDC 621.39}

doi:10.31799/1684-8853-2019-5-51-63

Performance evaluation of bandwidth reservation for mm Wave 5G NR systems

V. O. Begisheva, PhD, Phys.-Math., Associate Professor, orcid.org/0000-0002-7232-4157, begishev-vo@rudn.ru E. S. Sopina,b, PhD, Phys.-Math., Associate Professor, orcid.org/0000-0001-9082-2152

D. A. Molchanov a,c, PhD, Tech., Associate Professor, orcid.org/0000-0003-4007-7187

A. K. Samouylova,c, PhD, Phys.-Math., Associate Professor, orcid.org/0000-0002-2087-769X

Yu. V. Gaidamaka ${ }^{a, b}$, Dr. Sc., Phys.-Math., Professor, orcid.org/0000-0003-2655-4805

K. E. Samouylova,b, Dr. Sc., Tech., Professor, orcid.org/0000-0002-6368-9680

aPeoples' Friendship University of Russia (RUDN University), 6, Miklukho-Maklay St., 117198, Moscow, Russian Federation

bThe Institute of Informatics Problems of the Federal Research Center «Computer Science and Control» of the RAS, 44-2, Vavilov St., 119333, Moscow, Russian Federation

'Tampere University of Technology, 10, Korkeakoulunkatu, 33100, Tampere, Finland

Introduction: In 3GPP New Radio (NR) systems, frequent radio propagation path blockages can lead to the disconnection of ongoing sessions already accepted into the system, reducing the quality of service in the network. Controlling access to system resource by prioritizing for the ongoing sessions can increase the session continuity. In this paper, we propose resource allocation with a reservation mechanism. Purpose: Development of a mathematical model for analyzing the effect of this mechanism on other system performance indicators - dropping probabilities for new and ongoing sessions and system utilization. The model takes into account the key features of the 3GPP NR technology, including the height of the interacting objects, the spatial distribution and mobility of the blockers, as well as the line-of-sight propagation properties between the transceivers for mmWave NR technology. Results: We analyzed the reservation mechanism with the help of a developed model in the form of a resource queueing system with signals, where the base station bandwidth corresponds to the resource, and the signals model a change in the line-of-sight conditions between the receiving and transmitting devices. Creating a priority for ongoing sessions whose service has not yet been completed provides a considerable flexibility for balancing the session continuity and dropping of a new session, with a slight decrease in the efficiency of the radio resource utility. With the developed model, we showed that reserving even a small bandwidth (less than 10\% of the total resources) to maintain the ongoing sessions has a positive effect on their continuity, as it increases the probability of their successful completion. Practical relevance: 
The proposed mechanism works more efficiently in overload conditions and with sessions which have a high data transfer rate requirements. This increases the demand for the proposed mechanism in 5G NR communication systems.

Keywords - millimeter wave, 5G networks, New Radio, session continuity, bandwidth reservation, new session drop probability, ongoing session drop probability, system resource utilization.

For citation: Begishev V. O., Sopin E. S., Molchanov D. A., Samouylov A. K., Gaidamaka Yu. V., Samouylov K. E. Performance evaluation of bandwidth reservation for mmWave 5G NR systems. Informatsionno-upravliaiushchie sistemy [Information and Control Systems], 2019, no. 5, pp. 51-63 (In Russian). doi:10.31799/1684-8853-2019-5-51-63

\section{References}

1. Report ITU-R M.2376-0: Technical feasibility of IMT in bands above $6 \mathrm{GHz}$. ITU, Electronic Publication, Geneva, 2015. Available at: https://www.itu.int/dms_pub/itu-r/opb/ rep/R-REP-M.2376-2015-PDF-E.pdf (accessed 15 May 2019).

2. 3rd Generation Partnership Project: Technical Specification Group Radio Access Network, NR, Physical channels and modulation (Release 15), 3GPP TR 38.211, V15.6.0, 2019. Available at: https://www.3gpp.org/ftp/Specs/archive/38 series/38.211/ (accessed 10 June 2019).

3. Report Qualcomm: Making 5G NR a Commercial Reality, 2019. Available at: https://www.qualcomm.com/media/documents/files/making-5g-nr-a-commercial-reality.pdf (accessed 15 May 2019).

4. Tatarnikova T. M. Statistical methods for studying network traffic. Informatsionno-upravliaiushchie sistemy [Information and Control Systems], 2019, no. 5 , pp. 35-43 (In Russian). https://doi.org/10.31799/1684-8853-2018-5-35-43

5. Galinina O. S., Andreev S. D., and Tyurlikov A. M. On multiple access of a large number of machine-type devices in cellular networks. Informatsionno-upravliaiushchie sistemy [Information and Control Systems], 2019, no. 4, pp. 105-114 (In Russian). https://doi.org/10.31799/1684-8853-2019-4-105-114

6. Samuylov A., Gapeyenko M., Moltchanov D., Gerasimenko M., Singh S., Himayat N., Andreev S., and Koucheryavy Y. Characterizing spatial correlation of blockage statistics in urban mmWave systems. 2016 IEEE Globecom Workshops (GCWkshps), 2016, pp. 1-7. https://doi.org/10.1109/GLO COMW.2016.7848859

7. Gapeyenko M., Samuylov A., Gerasimenko M., Moltchanov D., Singh S., Akdeniz M., Aryafar E., Himayat N., Andreev S., and Koucheryavy Y. On the temporal effects of mobile blockers in urban millimeter-wave cellular scenarios. IEEE Transactions on Vehicular Technology 66, 2017, no. 11, pp. 10124-10138. doi:10.1109/TVT.2017.2754543

8. Michalopoulos D. S., Viering I., and Du L. User-plane multiconnectivity aspects in 5G. 2016 23rd International Confer ence on Telecommunications (ICT), May 2016, pp. 1-5.

9. Ohmann D., Awada A., Viering I., Simsek M., and Fettweis G. P. Achieving high availability in wireless networks by inter-frequency multi-connectivity. 2016 IEEE International Conference on Communications (ICC), May 2016, $7 \mathrm{p}$.

10. 3GPP, NR; Multi-connectivity; Overall description; Stage-2 (Release 15), 3GPP TR 37.340, December 2017. Available at:
https://www.3gpp.org/ftp/Specs/archive/37 series/ $37.340 /$ (accessed 23 april 2019).

11. Giordani M., Mezzavilla M., and Zorzi M. Initial access in $5 \mathrm{G}$ mmwave cellular networks. IEEE Communications Magazine, Nov. 2016, vol. 54, pp. 40-47.

12. Moltchanov D., Samuylov A., Petrov V., Gapeyenko M., Himayat N., Andreev S., and Koucheryavy Y. Improving session continuity with bandwidth reservation in mmwave communications. IEEE Wireless Communications Letters 8, 2019, no. 1, pp. 105-108. doi:10.1109/LWC.2018.2859988

13. Kingman J. F. C. Poisson processes. Wiley Online Library, 1993. 112 p. doi.org/10.1002/0470011815.b2a07042

14. Nain P., Towsley D., Liu B., and Liu Z. Properties of random direction models. IEEE 24th Annual Joint Conference of the IEEE Computer and Communications Societies, 2005 vol. 3, pp. 1897-1907. doi:10.1109/INFCOM.2005.1498468

15. Seitz N. ITU-T QoS standards for IP-based networks. IEEE Communications Magazine, 2003, vol. 41, no. 6, pp. 82-89.

16. Naumov B. A., Samouylov K. Analysis of networks of the resource queuing systems. Automation and Remote Control, 2018, vol. 5, pp. 59-68 (In Russian). doi.org/10.1134/ S0005117918050041

17. Friis H. T. A note on a simple transmission formula. Proceedings of the IRE, 1946, vol. 34(5), pp. 254-256. doi:10. 1109/JRPROC.1946.234568

18. Gapeyenko M., Samuylov A., Gerasimenko M., Moltchanov D., Singh S., Aryafar E., Yeh S., Himayat N., Andreev S., and Koucheryavy Y. Analysis of human-body blockage in urban millimeter-wave cellular communications. 2016 IEEE International Conference on Communications (ICC), 2016, 7 p. doi:10.1109/ICC.2016.7511572

19. Daley D. J. and Servi L. Idle and busy periods in stable $\mathrm{m} / \mathrm{m} / \mathrm{k}$ queues. Journal of Applied Probability, 1988, vol. 35 (4), pp. 950-962.

20. Constantine A. B., et al. Antenna theory: analysis and design. Microstrip Antennas. Third edition. John Wiley \& Sons, 2005. $1099 \mathrm{p}$.

21. Bobbio A. and Trivedi K. S. An aggregation technique for the transient analysis of stiff markov chains. IEEE Trans actions on Computers, 1986 , no. 9 , pp. 803-814.

22. Ciardo G. and Smirni E. Etaqa: an efficient technique for the analysis of qbd-processes by aggregation. Performance Evaluation, 1999, vol. 36, pp. 71-93. 


\title{
Применение автоматного подхода для персонализированной поддержки клинических процессов в медицине
}

\author{
Ю. В. Аксенова, студент orcid.org/0000-0002-1835-2237 \\ Н. В. Добренко , старший преподаватель, orcid.org/0000-0001-6206-8033 \\ А. С. Ватьян ${ }^{\text {a }}$, ассистент, orcid.org/0000-0002-5483-716X \\ P. О. Капустина , студент, orcid.org/0000-0003-3027-2704 \\ С. В. Осипов ${ }^{\mathrm{a}}$, студент, orcid.org/0000-0002-5761-4703 \\ П. Ю. Маврина, студент, orcid.org/0000-0001-8530-0077 \\ Н. Ф. Гусарова ${ }^{a}$ канд. техн. наук, доцент, orcid.org/0000-0002-1361-6037

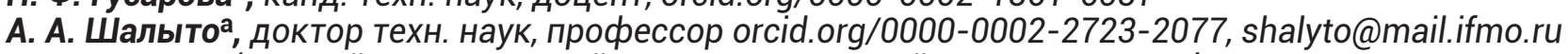

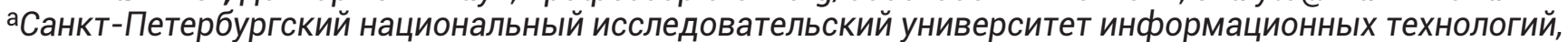 \\ механики и оптики, Кронверкский пр., 49, Санкт-Петербург, 197101, РФ
}

Введение: в рамках Национального проекта «Здравоохранение» большая роль отводится персонализации деятельности врача, для чего требуются системы поддержки принятия клинических решений. В существующих системах отсутствуют функции подсказки действий врача в ходе клинического процесса и выявления возможных противоречий между различными видами медицинских мероприятий, предлагаемых пациенту. Цель: разработка решения для персонализированной поддержки клинических процессов, свободного от указанных проблем. Методы: автоматный подход, который представляет клинический процесс как набор автоматных состояний и возможных переходов между ними, и набор паттернов проектирования Abstract Factory, Facade, Adapter и Visitor. Результаты: предложено решение для персонализированной поддержки клинических процессов на базе автоматного подхода и паттернов проектирования. Автоматный подход позволяет разделить клинический процесс на отдельные этапы и автоматически контролировать возможные переходы и условия их осуществления, включая проверку на наличие противопоказаний. Использование паттернов проектирования обеспечивает достаточную степень обобщенности, в результате можно, не затрагивая структуру основного кода приложения, оперативно подключать к системе необходимые источники информации, а также вносить в систему информацию о противоречиях различного генеза и учитывать их при принятии решения о ведении конкретного пациента. Практическая значимость: разработанное решение более эффективно, нежели в имеющихся системах, реализует подсказку действий врача в ходе клинического процесса и выявляет возможные противоречия между различными видами медицинских мероприятий, предлагаемых пациенту.

Ключевые слова - автоматное программирование, управляющие конечные автоматы, клинические протоколы, поддержка принятия решения, медицинские процессы.

Для цитирования: Аксенов Ю. В., Добренко Н. В., Ватьян А. С., Капустин Р. О., Осипов С. В., Маврин П. Ю., Гусарова Н. Ф., Шалыто А. А. Применение автоматного подхода для персонализированной поддержки клинических процессов в медицине. Инфорлационно-управляющие системы, 2019, № 5, с. 64-75. doi:10.31799/1684-8853-2019-5-64-75

For citation: Aksenov I. V., Dobrenko N. V., Vatyan A. S., Kapustin R. O., Osipov S. V., Mavrin P. Y., Gusarova N. F., Shalyto A. A. Automata approach for personalized support of clinical processes in healthcare. Informatsionno-upravliaiushchie sistemy [Information and Control Systems], 2019, no. 5, pp. 64-75 (In Russian). doi:10.31799/1684-8853-2019-5-64-75

\section{Введение}

Одним из ключевых направлений Национального проекта «Здравоохранение» на 2018-2024 гг. является развитие электронного здравоохранения. В рамках обширного комплекса задач этого направления Минздрав РФ выделяет создание систем поддержки принятия клинических решений (СПКР) для врачей в форме «...рабочего стола как клинического протокола, который подсказывает алгоритмы дальнейших действий - в плане и тактических лечебных (что нужно и как провести), и дополнительного обследования» [1]. Среди большого и во многом противоречивого набора ограничений (O), которому должна удовлетво- рять СПКР, ключевыми представляются следующие.

01. Стандартизация. СПКР должна соответствовать рамочным стандартам, принятым в здравоохранении, в том числе в аспекте терминологии, и в то же время адаптироваться под конкретные стандарты лечебного учреждения. Так, в настоящее время в медицинских учреждениях РФ используются разные информационные стандарты (например, 13606/OpenEHR Archetypes [2], Health Level 7 [3]), различающиеся не только по модели данных, но даже по терминологии.

О2. Персонализация. СПКР должна предоставить врачу возможность при каждом принятии решения учитывать специфические особенности 
конкретного пациента, в том числе индивидуальные реакции на лекарственные препараты и другие потенциально возможные противопоказания.

О3. Безопасность и целостность данных. В РФ действует комплекс законодательных актов, направленных на защиту медицинской информации (в том числе № 323-Ф3 и 152-ФЗ), обеспечивающий конфиденциальность персональных данных. Как показывает практика, не менее важной проблемой является защита от несанкционированного изменения и предумышленной фальсификации, причем со стороны не только медицинского, но и технического персонала, и даже самого пациента.

Учитывая эти ограничения, можно сформулировать концептуальные требования (Т) к архитектурному решению СПКР:

T1) гибкое взаимодействие со сложной и многосвязной структурой медицинских данных в целом, при этом изменения в структуре данных должны как можно меньше влиять на прикладной программный код;

T2) гибкая структура запросов, организуемых, как правило, по сценарному типу;

T3) расширяемость в соответствии с вновь возникающими классами задач, характерными для конкретного пациента.

На рынке и в литературе представлены разнообразные системы, поддерживающие различные аспекты электронного здравоохранения (их краткий обзор приведен в первом разделе). Но, как показывает анализ и подтверждает практика, среди них отсутствуют системы, полномасштабно удовлетворяющие сформулированным выше требованиям и ограничениям. В настоящей статье предлагается решение для разработки таких систем на базе автоматного подхода [4].

\section{Терминология и существующие решения}

Выбор понятийной и терминологической базы во многом предопределяет эффективность любой медицинской информационной системы, и СПКР в том числе [5]. В настоящей работе мы опираемся на терминологию системы стандартов ИСО «Медицинская информатика», одним из разработчиков которой явилась РФ, в частности, на стандарт [6], который определяет следующие понятия:

— клинический процесс (clinical process CP) - медицинский процесс, охватывающий все действия поставщиков медицинских услуг;

- состояние здоровья (health state - HS) физические и психические функции, структура тела, личностные факторы, активность, участие и экологические аспекты как составляющие эле- менты здоровья субъекта; в рамках клинического процесса рассматриваются отдельные клинические состояния здоровья;

- клинические симптомы (health condition HC) - наблюдаемые или потенциально наблюдаемые аспекты состояния здоровья в данный момент времени;

- клиническое мероприятие (healthcare activity - HA) - деятельность, направленная прямо или косвенно на улучшение или поддержание состояния здоровья; оно может состоять из нескольких компонентов;

- клинический факт (healthcare matter HМ) - факт, который определен одним из субъектов клинического процесса как относящийся к здоровью пациента.

Преимущество этой системы терминов состоит в том, что она, с одной стороны, легко интерпретируется врачом, а с другой стороны, может быть непосредственно транслирована в концепты информационной системы. В качестве примера в табл. 1 представлен фрагмент описания клинического процесса бронхиальной астмы [7, 8], а в табл. 2 - формализованное описание его компонентов через клинические факты.

На российском рынке достаточно широко представлены различные СПКР [9]. Детальный анализ показал, что в них по отдельности или в комбинации реализуется следующий функционал: поддержка отдельных диагностических процедур (например, автоматизированный анализ рентгенограмм, КТ- и МРТ-изображений); статистическая оценка показателей и доступ к медицинским калькуляторам; информационно-справочные функции (например, проверка совместимости лекарств, структурированный доступ к медицинской информации); протоколирование показателей в ходе удаленного мониторинга пациентов; ручное протоколирование выполнения назначений (в ходе лечения в клинике). Однако функцию подсказки алгоритмов действий врача в ходе клинического процесса, заявленную в работе [1], в них обнаружить не удалось.

Недостаточное внимание в существующих СПКР уделяется также персонализации. Обзор решений в области медицинских информационных систем показывает, что в них преобладает подход типизации различных аспектов клинического процесса, т. е. формирование и поддержка единого процесса для определенных групп пациентов. Например, в работе [10] предлагается система многосторонней поддержки типичного хирургического процесса, а в [11, 12] - группирование пациентов в процессе лечения в зависимости от того, какую помощь они получали ранее. С другой стороны, системы типа [13], нацеленные на персонализацию диагностического процесса, обычно строго адаптированы к узкому заболева- 
- Tаблица 1. Содержательное описание клинического процесса

- Table 1. Overall description of the clinical process

\begin{tabular}{|c|c|c|}
\hline $\begin{array}{c}\text { Состояние } \\
\text { здоровья }\end{array}$ & Клинические симптомы & Клинические мероприятия \\
\hline HSO & $\begin{array}{l}\text { НС0. Исчезновение свистящих } \\
\text { хрипов, пиковая скорость } \\
\text { выхода (ПСВ) > } 80 \text { \% } \\
\text { от лучшей или должной }\end{array}$ & НА0. Амбулаторное лечение \\
\hline HS1 & $\begin{array}{l}\text { НC1. Признаки приступа } \\
\text { бронхиальной астмы }\end{array}$ & $\begin{array}{l}\text { НА1. Продолжить прием } \beta_{2} \text { агонистов длительного действия (LABA) } \\
\text { каждые } 3-4 \text { часа }\end{array}$ \\
\hline HS2 & $\begin{array}{l}\text { НС2. Свистящие хрипы } \\
\text { остаются, ПСВ }=60-80 \% \text { от } \\
\text { лучшей или должной }\end{array}$ & $\begin{array}{l}\text { HА2.1. Предложить госпитализацию в стационар } \\
\text { HА2.2. При отказе от госпитализации: продолжить LABA } \\
\text { в прежней дозе каждый час + преднизолон внутрь } 30 \text { мг + осмотр } \\
\text { пульмонолога для коррекции базовой терапии }\end{array}$ \\
\hline HS3 & $\begin{array}{l}\text { НС3. Нарастание симптомати- } \\
\text { ки, ПСВ < } 60 \text { \% от лучшей } \\
\text { или должной }\end{array}$ & $\begin{array}{l}\text { НА3.1. Предложить госпитализацию в стационар } \\
\text { НА3.2. Продолжить LABA + глюкокортикостероиды (ГКС) } \\
\text { перорально (преднизолон } 30 \text { мг) + ингаляции атровента } 40 \text { мг через } \\
\text { дозированный аэрозоль, или } 0,5 \text { мг через небулайзер, или эуфиллин } \\
2,4 \%-10,0 \text { внутривенно медленно }\end{array}$ \\
\hline HS4 & $\begin{array}{l}\text { НС4. Стационарный этап, } \\
\text { среднетяжелое обострение } \\
\text { (нарастание симптоматики, } \\
\text { ПСВ < } 60 \text { \% от лучшей или } \\
\text { должной, } \mathrm{SpO}_{2}<90 \% \text { ) }\end{array}$ & $\begin{array}{l}\text { HA4.1. } \beta_{2} \text { агонисты короткого действия (SABA) через небулайзер по } \\
\text { одной дозе (вентолин } 2,5 \text { мг или беротек } 0,5 \text { мг) каждые } 20 \text { мин } \\
\text { в течение первого часа (если не проводились амбулаторно), далее } \\
\text { SABA в прежних дозах каждые } 60 \text { мин через небулайзер } \\
\text { HA4.2. Оксигенотерапия для достижения сатурации } \mathrm{SpO}_{2}>90 \%\end{array}$ \\
\hline HS5 & $\begin{array}{l}\text { Стационарный этап лечения, } \\
\text { неполный ответ } \\
(П С \mathrm{C}=50-70 \% \text { от лучшей } \\
\left.\text { или должной, } \mathrm{SpO}_{2}<90 \%\right)\end{array}$ & $\begin{array}{l}\text { НА5. Системные кортикостероиды (СКС) внутривенно (преднизолон } \\
90 \text { мг, солюкортеф 100-200 мг), эуфиллин внутривенно капельно } \\
\text { (мониторинг эуфиллина) }\end{array}$ \\
\hline HS6 & Отсутствие улучшения & НА6. Перевод в отделение интенсивной терапии (ОИТ) \\
\hline
\end{tabular}

- Таблица 2. Формализованное описание компонентов клинического процесса

- Table 2. Formalized description of the components of the clinical process

\begin{tabular}{|c|c|c|}
\hline Наименование & Содержание & Значения \\
\hline $\begin{array}{l}\mathrm{HM}_{\mathrm{C}}-\text { клинические } \\
\text { факты, отражающие } \\
\text { клинические симптомы }\end{array}$ & $\begin{array}{l}\text { НМ1. Свистящие хрипы (CX) } \\
\text { НM2. ПСВ } \\
\text { НМ3. } \mathrm{SpO}_{2} \\
\text { НМ4. Этап лечения } \\
\text { НМ5. Динамика состояния }\end{array}$ & 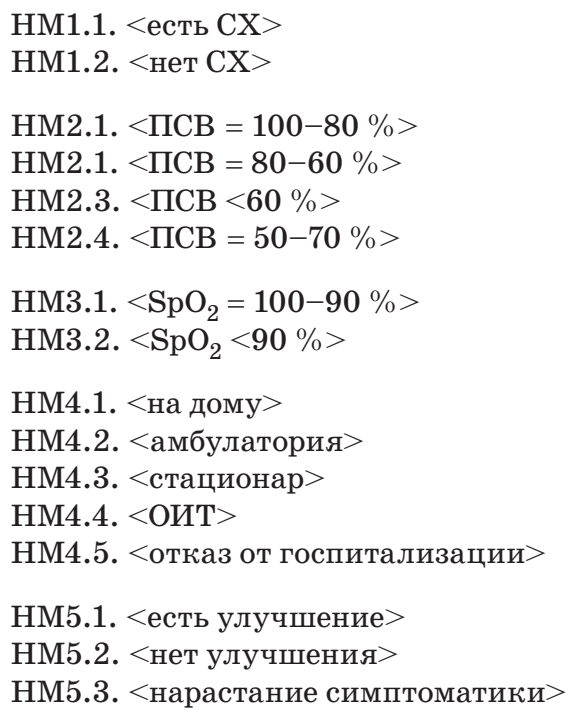 \\
\hline
\end{tabular}


- Окончание табл. 2

- Table 2 (compl.)

\begin{tabular}{|c|c|c|}
\hline Наименование & Содержание & Значения \\
\hline \multirow{9}{*}{$\begin{array}{l}\mathrm{HM}_{\mathrm{A}}-\text { клинические } \\
\text { факты, отражающие } \\
\text { клинические мероприятия }\end{array}$} & HM6. LABA & HM6.1. $<\mathrm{LABA}, \Delta t=3-4 \mathrm{u}>$ \\
\hline & HM7. SABA & HM7.1. $<$ SABA, $\Delta t=0,3 \mathrm{ч}>$ \\
\hline & & HM7.2. $<\mathrm{SABA}, \Delta t=1 \mathrm{ч}>$ \\
\hline & HМ8. ГКС & НМ8.1. <преднизолон, 30 мг> \\
\hline & HM9. СКС & НМ9.1. <преднизолон, 90 мг, в/в> \\
\hline & & $\begin{array}{l}\text { НМ9.2. <солу-кортеф, } 100-200 \text { мг, в/в> } \\
\text { НМ9.3. <атровент, ингаляции> }\end{array}$ \\
\hline & HМ10. Оксигенотерапия & НМ 10.1. <оксигенотерапия> \\
\hline & НМ11. Эуфиллин & НМ11.1 < эуфиллин, в/в> \\
\hline & НМ12. Осмотр пульмонолога & НМ12.1 < осмотр пульмонолога> \\
\hline $\begin{array}{l}\text { НА - клинические } \\
\text { мероприятия }\end{array}$ & $\begin{array}{l}\text { HA0 } \\
\text { HA1 } \\
\text { HA2.1 } \\
\text { HA2.2 } \\
\text { HA3.1 } \\
\text { HA3.2 } \\
\text { HA4.1 } \\
\text { HA5 } \\
\text { HA6 }\end{array}$ & $\begin{array}{l}\text { HM4.1 + HM6.1 } \\
\text { HM4.1 } \\
\text { HM4.3 } \\
\text { HM6.1 + HM8.1 + HM12.1 } \\
\text { HM4.3 } \\
\text { HM6.1 + HM8.1 + HM9.3 + HM11.1 } \\
\text { HM7.1 + HM7.2 + HM10 } \\
\text { HM9.1 + HM9.2 + HM11.1 } \\
\text { HM4.4 }\end{array}$ \\
\hline $\begin{array}{l}\text { НС - клинические } \\
\text { симптомы }\end{array}$ & $\begin{array}{l}\text { HC0 } \\
\text { HC1 } \\
\text { HC2 } \\
\text { HC3 } \\
\text { HC4 } \\
\text { HC5 } \\
\text { HC6 }\end{array}$ & 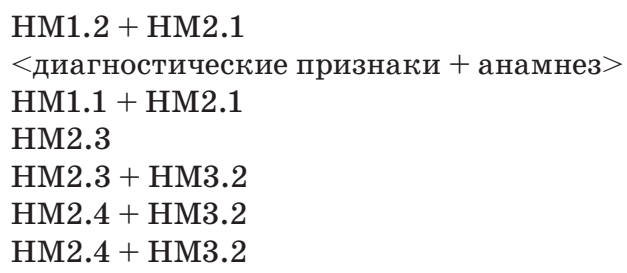 \\
\hline
\end{tabular}

нию и не обеспечивают необходимой вариативности в принятии врачебных решений.

Существенную роль в персонализации клинического процесса играют возможные противоречия между различными видами медицинских мероприятий, предлагаемых пациенту, выявить которые еще на стадии принятия решения - одна из задач СПКР. Например, назначаемое лекарство может ухудшить течение другой болезни, которой страдает пациент (противоречие НА-CP), может быть противопоказано ему в связи с некоторыми параметрами анамнеза (противоречие НA-HS) или вступать в нежелательные взаимодействия с другими лекарствами, которые принимает пациент (противоречие НА-НА). Для выявления таких противоречий предложены два подхода.

Первый подход основан на объединении всей доступной информации о противопоказаниях в единую базу данных, к которой врач должен самостоятельно формировать запросы [14-16]. Очевидно, что такая интегрированная база становится очень «тяжелой», соответствующие системы являются проприетарными (см. примеры [15]), врачи не могут вносить в них изменения и с трудом осваивают их на практике.
Предлагаются также «легкие» решения для выявления противоречий по конкретному пациенту или заболеванию. Для этого использованы, например, онтологический подход - связывание интересующих терминов (названий лекарств и диагнозов) с собственными и (или) сторонними онтологиями и SPARQL-запрос на поиск лекарств, которые могут вступить во взаимодействие [17]. Применяются также системы продукционных правил или логические выражения [18-20]. Такие системы создаются вручную для конкретной задачи и не допускают масштабирования.

Выбранный концептуальный и терминологический подход к описанию клинических процессов, проиллюстрированный табл. 1 , позволяет применить для их моделирования в рамках СПКР такой мощный подход, как автоматное программирование $[4,21]$. Концепция автоматов достаточно широко используется в здравоохранении, например, для оценки распространения бактерий при заболевании [22], для планирования удаленного ухода за пациентами [23], для анализа эффективности взаимодействия между отдельными органами [24]. Однако при моделировании собственно клинических процессов автоматный подход использу- 
ется только как жестко детерминированная конструкция $[10,11,25]$, в то время как современные средства поддержки автоматного программирования предоставляют широкие возможности для моделирования процессов принятия решения [26].

Таким образом, проведенный обзор подтвердил, что сформулированные во введении требования к СПКР остаются в значительной степени невыполненными, и в то же время позволил определить адекватную терминологическую структуру и программный подход для их моделирования.

\section{Предлагаемое решение}

\section{Автоматная модель}

Решение базируется на автоматной модели, которая представляет клинический процесс как набор автоматных состояний и возможных переходов между ними. На рис. 1 изображена диаграмма состояний автомата, описывающего фрагмент клинического процесса бронхиальной астмы в соответствии с табл. 1. Конкретному клиническому состоянию (HS) может соответствовать несколько автоматных состояний (AS), каждое из которых описывается набором клинических фактов $\left(\mathrm{HM}_{\mathrm{A}}\right)$, отражающих клинические мероприятия (НА). Условия переходов между состояниями задаются наборами клинических фактов $\left(\mathrm{HM}_{\mathrm{C}}\right)$, отражающих клинические симптомы (НC).

В табл. 3 представлены компоненты диаграммы состояний в терминах типовой автоматной модели [4]:

$$
\mathrm{A}=\left(\Sigma, Q, q_{0}, T S, P\right),
$$

где $\Sigma$ - входной алфавит; $Q-$ конечное множество состояний автомата; $q_{0}$ - начальное состоя-

Tаблица 3. Компоненты диаграммы состояний в терминах автоматной модели

- Table 3. Components of the state diagram in terms of automata model

\begin{tabular}{|c|c|}
\hline $\begin{array}{l}\text { Компонент } \\
\text { автоматной } \\
\text { модели }\end{array}$ & $\begin{array}{c}\text { Компоненты модели клинического } \\
\text { процесса }\end{array}$ \\
\hline$\sum$ & HC0, HC1, HC2, HC3, HC4, HC5, HC6 \\
\hline$Q$ & $\begin{array}{l}\text { HA0, HA1, HA } 2.1 \text {, HA2.2, HA3.1, } \\
\text { HA } 3.2 \text {, HA4.1, HA5, HA6 }\end{array}$ \\
\hline$q_{0}$ & HM4.1 \\
\hline$T S$ & $\begin{array}{l}\mathrm{HS} q_{0} t \text { (Not asthma), } \mathrm{HS}_{0} t \text { (Ambulatory } \\
\text { treatment), HS3 } t \text { (Ambulatory treat- } \\
\text { ment), HS4 } t \text { (Ambulatory treatment), } \\
\text { HS6 } t \text { (Intensive care unit) }\end{array}$ \\
\hline$P$ & $P 1-P 30$ \\
\hline
\end{tabular}

ние; TS - множество конечных состояний; $P$ функции переходов.

Выделим специфику предложенной автоматной модели в связи с ее применением в клиническом процессе. Все функции переходов здесь яв-
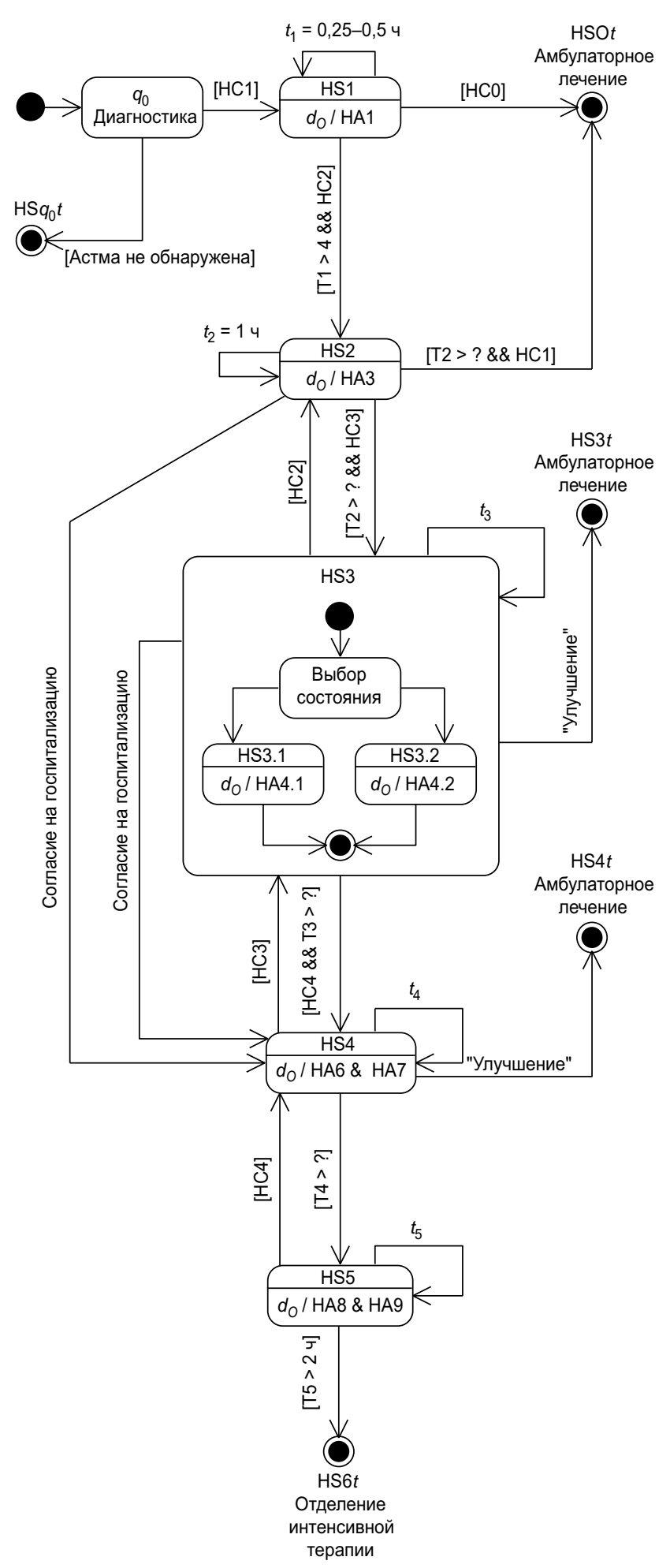

- Puc. 1. Диаграмма состояний автомата

- Fig. 1. The generalized automata model 
ляются не абсолютными, а информирующими в определенный момент инициируют оповещение врача о необходимости перехода. Момент принятия врачебного решения о переходе может быть установлен таймером или счетчиком возвратов, который соотнесен с соответствующим клиническим симптомом.

Применение автоматной модели дает следующие преимущества:

- возможна формальная проверка и протоколирование действий всех участников клинического процесса;

- улучшается наблюдаемость клинического процесса за счет использования одной внутренней переменной;

- внутри каждого состояния легко организовывать новые и взаимозаменяемые исследования, что позволяет гибко адаптировать клинический процесс к изменяющимся внешним условиям.

\section{Модель системы}

Опишем функциональность предлагаемой системы, приведем ее общую схему, а затем подробно рассмотрим все этапы ее работы.

Идея функционирования системы заключается в следующем. Она агрегирует в себе информацию о пациенте: анамнез, медицинские противопоказания, результаты медицинских исследований, сдачи анализов и измерений. На основе этих данных с учетом противопоказаний, анамнеза и текущего состояния автоматной модели формируются списки доступных переходов автоматной модели, рекомендуемых переходов и возможных противопоказаний.

Пользователь системы делает выбор следующего состояния из предложенного списка доступных переходов. Процесс смены состояний длится до момента достижения одного из терминальных состояний. Каждое такое состояние соответствует определенному мероприятию, например выздоровление, госпитализация, изменение поставленного ранее диагноза и, соответственно, лечения.

Противопоказания могут быть сформированы на основе данных, хранящихся в различных источниках. Это может быть база данных, кэшсистемы, внешние онтологии и EHR (электронная медицинская карта). На основе анализа внешних источников информации формируются новые пары противопоказаний.

Можно выделить следующие основные этапы работы системы:

1) инициализация нового клинического процесса;

2) создание новой сущности пациента;

3) вход в текущее состояние, оповещение о нем;

4) заполнение анамнеза пациента;

5) фиксация медицинских противопоказаний пациента;
6) внесение результатов анализов и измерений, получение необходимой внешней информации;

7) проверка условий выхода из текущего состояния;

8) формирование оповещения о необходимости перехода;

9) оценка рекомендуемых состояний на основе информации о противопоказаниях;

10) предоставление информации о доступных состояниях, рекомендованном состоянии и противопоказаниях;

11) переход в новое состояние автоматной модели;

12) достижение одного из терминальных состояний.

Модель данных разработанной системы представлена на рис. 2. Базовыми сущностями являются классы Patient и ClinicalProcess. В классе Patient аккумулируются три типа информации о пациенте:

- информация о клинических симптомах, отражающих течение клинического процесса; класс Patient содержит коллекцию экземпляров класса Measurements;

- информация из анамнеза пациента, относящаяся к данному клиническому процессу; она хранится в классе CaseHistory, ассоциированном с классом Patient;

- информация о специфичных для данного пациента последствиях перехода в то или иное состояние; она поступает из интерфейсного класса Contradiction.

Класc ClinicalProcess содержит коллекцию экземпляров класса State, которые базируются на информации только первого типа. Возможности персонализации клинического процесса обеспечиваются ассоциативной связью классов ClinicalProcess и Patient.

Таким образом, предлагаемая система поддерживает работу врача в соответствии с базовым клиническим процессом, определяемым после-

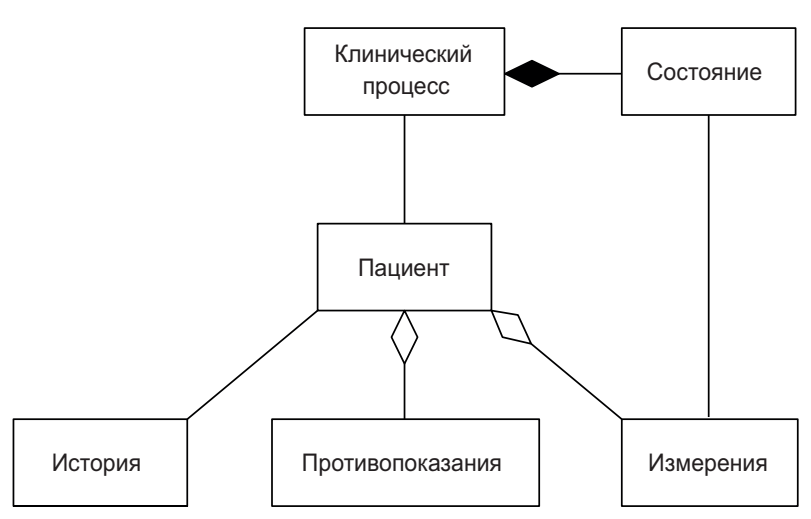

- Puc. 2. Модель данных

- Fig. 2. Data model 
довательностью состояний автоматной модели, и в то же время позволяет, при необходимости и (или) при наличии соответствующей информации, производить персонализацию клинического процесса, учитывая данные анамнеза конкретного больного и сведения о возможных противоречиях в назначениях.

\section{Паттерны проектирования}

\section{как средство описания противоречий}

В ходе клинического процесса между различными медицинскими мероприятиями могут возникать противоречия, о которых желательно информировать врача еще на стадии принятия врачебного решения о переходе в следующее состояние. Как показал анализ, описанные выше подходы к их выявлению не в полной мере отвечают сформулированным выше требованиям к СПКР, особенно к Т2 и Т3. Следуя реальной клинической практике, в разрабатываемом решении предлагается постепенное наращивание перечня клинических фактов и (или) медицинских мероприятий, которые врач считает нужным принимать во внимание при оценке потенциальных противоречий в ходе лечения конкретного больного. С этой целью решение строится с использованием паттерна проектирования Абстрактная фабрика (Abstract Factory) [27, 28], который предоставляет интерфейс для создания семейств взаимосвязанных или взаимозависимых объектов, не специфицируя их конкретных классов. Пример структуры классов для описания противоречий на основе паттерна Abstract Factory представлен на рис. 3.

Интерфейсный класс IMedicalFactory (cм. рис. 3) порождает конкретные фабрики, каждая из которых соответствует одной из вышеупомянутых пар источников противоречий: DiseaseFactory содержит описание противоречия НА-НР, DrugFactory - противоречия HA-HA, AnamnesisFactory - противоречия HA-HS.

Достоинством паттерна Abstract Factory применительно к решаемой задаче является то, что он позволяет конфигурировать систему в целом любым семейством составляющих ее объектов. В зависимости от того, какой именно клинический факт врач выбирает в качестве приоритетного источника противоречий, управление передается той или иной конкретной фабрике, которая инициирует формирование соответствующего списка противопоказаний и возможных замен. Например, если врач считает, что главным источником проблем при переходе к следующему состоянию, т. е. при назначении конкретного лекарства, будет возраст пациента, то создается экземпляр фабрики AnamnesisFactory, которая покажет противопоказания к применению конкретного лекарства по возрасту, а также возможные альтернативы.
Паттерн Посетитель (Visitor) используется для того, чтобы вынести логику принятия решения из самих состояний, что позволяет проектировщику системы добавлять операции обработки конкретных состояний, не изменяя классы самих состояний. Например, если в качестве источника противоречий требуется реализовать обработку какого-либо компонента анамнеза, то при отсутствии паттерна Visitor нужно было бы добавить метод обработки этого компонента в каждый дочерний класс класса BaseState (см. рис. 3).

В системе обрабатываются события различных типов: как связанные с динамикой клинических фактов, так и инспирируемые врачом и связанные с принятием врачебных решений. Прием событий первого типа осуществляется производными классами интерфейсов IVisitor и IContradictionProvider. На основе этих данных они принимают решение о возможности перехода в доступные состояния и наличии противопоказаний. Для управления обработкой событий, поступающих от врача, служит класс AutomataDispatcher. Методы этого класcа setFactory() и setState() устанавливают текущую фабрику (в соответствии с решением врача о приоритете лекарства, болезни или анамнеза пациента) и выбранное врачом состояние, относительно которого формируется желаемая информация. Методы getAvailableStates() и getContradictions() возвращают информацию о доступных для перехода в данный момент состояниях и текущих противопоказаниях.

Для принятия клинических решений врачу должен быть предоставлен оперативный доступ к разнообразным источникам информации. С этой целью используется паттерн Адаптер (Adapter), который позволяет получить доступ к различным источникам данных, в том числе к EHR пациента и к внешним онтологиям, в унифицированном формате.

Класс AutomataDispatcher, реализующий паттерн Фасад (Facade), позволяет скрыть сложность системы путем агрегирования всех возможных внешних вызовов к объекту данного класса.

Таким образом, использование паттернов проектирования Abstract Factory, Facade, Adapter и Visitor в предложенном решении обеспечивает достаточную степень обобщенности, позволяя тем самым, не затрагивая структуру основного кода приложения, оперативно подключать к системе необходимые источники информации, а также вносить в систему информацию о противоречиях различного генеза и учитывать их при принятии решения о ведении конкретного пациента.

\section{Интерфейс взаимодействия с врачом}

Как подчеркивалось выше, разрабатываемая система предназначается не для замены врача, а для поддержки принятия им персонализиро- 


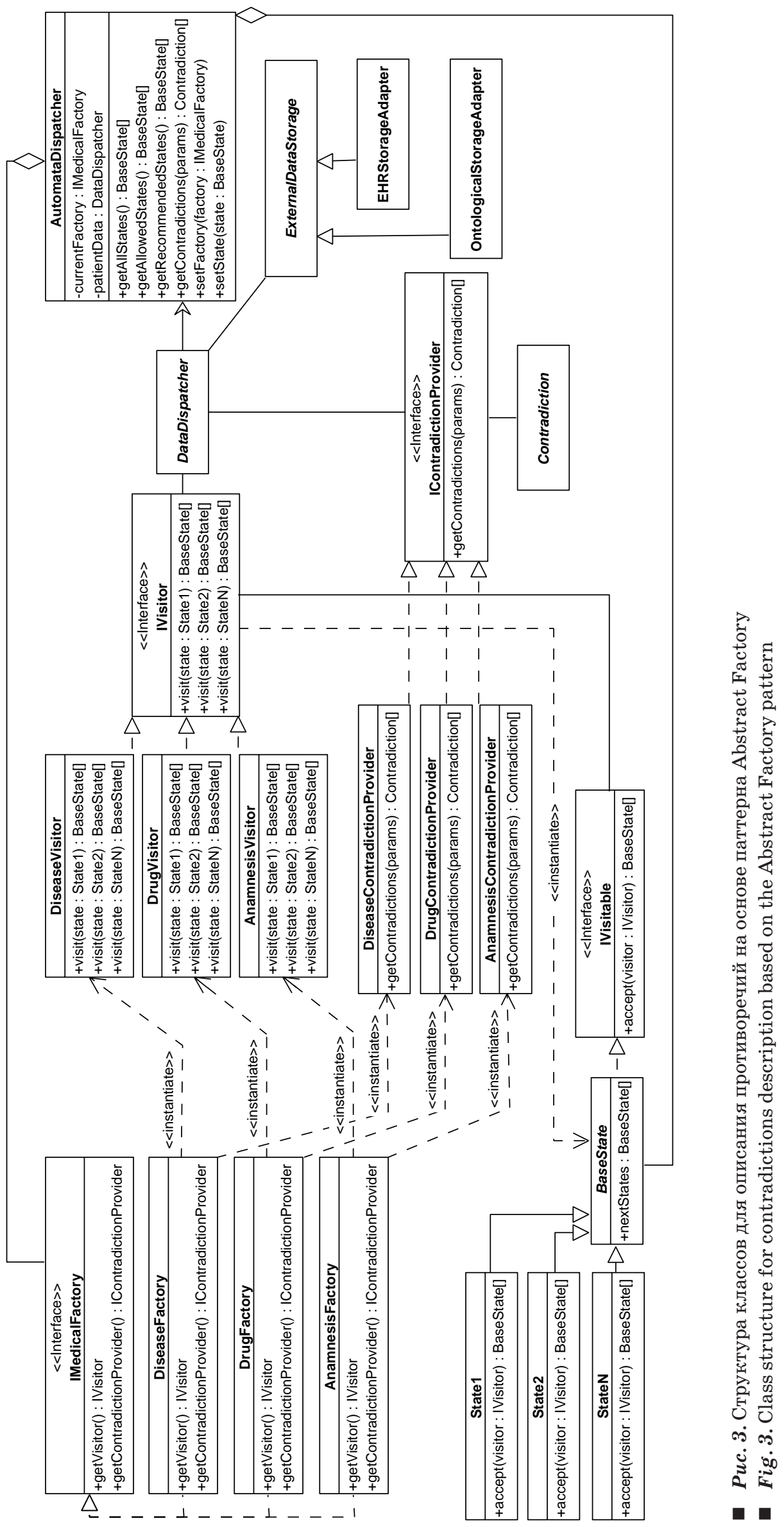


ванных клинических решений. В соответствии с этой целью система предоставляет врачу следующую интерфейсную информацию:

- о текущем состоянии клинического процесса (в соответствии с номером состояния HS);

- о необходимости принятия очередного клинического решения (в соответствии с таймером или счетчиком возвратов, предусмотренным в каждом состоянии HS);

- о доступных переходах (в соответствии с методом getAvailableStates());

- о рекомендуемых переходах (в соответствии с методом getRecommendedStates());

- о возможных противопоказаниях или других противоречиях при выбираемом врачом переходе (в соответствии с методом getContradictions()).

Проиллюстрируем реализацию предложенного решения на типичном примере из клинической практики.

Пусть клинические симптомы пациента соответствуют НС4. В соответствии с автоматной моделью врачу сообщается информация, что пациент находится в состоянии HS4 и к нему необходимо применить клинические мероприятия НА4.1. Однако в комплекс мероприятий НА4.1 входят два препарата на выбор - беротек и вентолин. Пусть врач считает, что главным фактором для указанного выбора является анамнез пациента. В этом случае вызывается метод setFactory() и в него передается экземпляр AnamnesisFactory. Далее вызывается метод getAllowedStates(), и фабрика выпускает экземпляр AnamnesisVisitor (рис. 4). Для текущего состояния автомата запускается метод accept(), в который передается экземпляр AnamnesisVisitor. Соответствующий метод из AnamnesisVisitor проверяет наличие доступных переходов и возвращает список тех состояний, которые удовлетворяют предикатам, записанным на переходах. Например, если удовлетворяется только предикат НС3, то рекомендуется перейти в состояние HS3. При этом врачу демонстрируется список доступных состояний, а также рекомендуемое для перехода состояние.

Для получения информации о противопоказаниях производится вызов метода getContradictions(), в который передается экземпляр объекта DataDispacher (см. рис. 4), и система производит оценку взаимодействий беротека и вентолина с компонентами анамнеза пациента. Обращаясь к EHR пациента через EHRStorageAdapter (cм. рис. 4), система находит у пациента в анамнезе гипертрофическую обструктивную кардиомиопатию и ищет информацию о противопоказаниях к применению беротека и вентолина у пациентов с данным заболеванием. Система может либо найти ее в своей базе данных, либо обратиться к классу DataDispatcher, который, в свою очередь, осуществляет поиск нужной информации в своем кэше или делает запрос к источнику онтологии. Последний через OntologyStorageAdapter реализует паттерн Adapter для представления запрашиваемой информации в требуемом формате. В результате система находит информацию о противопоказаниях к применению беротека у пациентов с данным заболеванием и не находит таковую по отношению к вентолину. Система сообщает данную информацию врачу и рекомендует использовать вентолин.

\section{Заключение}

В статье предложено решение для персонализированной поддержки клинических процессов, построенное на основе концепции автоматного программирования с использованием шаблонов проектирования. Решение удовлетворяет требованиям, предъявляемым к СПКР, а именно:

- терминология соответствует спецификациям и стандартам, принятым в медицинской практике, что обеспечивает ее прозрачность и простоту использования для медицинских работников;

- поддерживается работа врача в соответствии с базовым клиническим процессом, определяемым последовательностью состояний автоматной модели; в то же время врач имеет возможность при необходимости и (или) при наличии соответствующей информации производить персонализацию клинического процесса, учитывая данные анамнеза конкретного больного и сведения о возможных противоречиях в назначениях;

- применение паттернов проектирования обеспечивает гибкость и расширяемость спецификаций медицинского процесса;

- гибко и независимо подключаются внешние источники данных, в том числе онтологические системы, с возможностью их активации и деактивации во время работы.

Результаты работы частично докладывались на международной конференции [29].

\section{Литература}

1. Брифинг Министра Вероники Скворцовой. 13 декабря 2017. https://www.rosminzdrav.ru/news/2017/12/ 13/6603-brifing-ministra-veroniki-skvortsovoy-pozaversheni-zasedaniya-prezidiuma-soveta-pri- prezidente-rossiyskoy-federatsii-po-strategicheskomurazvitiyu-i-prioritetnym-proektam-pod-predsedatelstvom-dmitriya-medvedeva (дата обращения: 31.05.2019).

2. OpenEHR Architecture Overview, openEHR 2007. Eds. S. Heard \& T. Beale. https://specifications. 
openehr.org/releases/1.0.2/architecture/overview. pdf (дата обращения: 31.05.2019).

3. HL7 standard description. http://www.mcis.duke. edu/standarts/HL7/hl7.htm (дата обращения: 31.05.2019).

4. Поликарпова Н. И., Шалыто А. А. Автоматное программирование. СПб., Питер, 2009. 176 с.

5. Ваганова Е. В. Медицинские информационные системы как объект оценки: факторы и тенденции развития. Вестник Томского государственного университета. Экономика, 2017, № 37, с. 113-130.

6. ISO 13940-2016 Health informatics - system of concepts to support continuity of care (ISO 13940:2015). https://www.iso.org/standard/58102.html (дата обращения: 31.05.2019).

7. Tsung-Hsien Yu, Pin-Kuei Fu, and Yu-Chi Tung. Using medication utilization information to develop an asthma severity classification model. BMC Medical Informatics and Decision Making, Dec. 2017, vol. 17, p. 177. https://doi.org/10.1186/s12911-017-0571-9

8. Назаренко Г. И., Осипов Г. С. Основы теории медицинских технологических процессов. Ч. 1. М., Физматлит, 2005. 144 с.

9. Гусев А. Обзор российских систем поддержки принятия врачебных решений. 30 Сент. 2018. http:// www.kmis.ru/blog/obzor-rossiiskikh-sistempodderzhki-priniatiia-vrachebnykh-reshenii (дата обращения: 31.05.2019).

10. Neumuth T. Surgical Process Modeling - Theory, Methods, and Applications. The Universität Leipzig, 2012. $279 \mathrm{p}$.

11. Hommersom A., Verwer S., Lucas P. J. F. Discovering Probabilistic Structures of Healthcare Processes. Process Support and Knowledge Representation in Health Care. ProHealth, 2013, AIME 2013 Joint Workshop, KR4HC 2013/ProHealth 2013, Murcia, Spain, June 1, 2013, Revised Selected Papers, pp. 53-67.

12. Ferrante S., Bonacina S., Pozzi G., Pinciroli F., Marceglia S. A design methodology for medical processes. Appl Clin Inform., 2016, vol. 7, pp. 191-210. http:// dx.doi.org/10.4338/ACI-2015-08-RA-0111

13. Zhaoyi Chen, Victoria Y. Bird, Rupam Ruchi, Mark S. Segal, Jiang Bian, Saeed R. Khan, Marie-Carmelle Elie, and Mattia Prosperi. Development of a personalized diagnostic model for kidney stone disease tailored to acute care by integrating large clinical, demographics and laboratory data: the diagnostic acute care algorithm — kidney stones (DACA-KS). BMC Medical Informatics and Decision Making, 2018, vol. 18, no. 72. https://doi.org/10.1186/s12911-018-0652-4

14. Boussadi A., Zapletal E. A Fast Healthcare Interoperability Resources (FHIR) layer implemented over i2b2. BMC Medical Informatics and Decision Making, 2017, vol. 17, no. 120. https://doi.org/10.1186/ s12911-017-0513-6

15. Monica K. Top Clinical Decision Support System (CDSS) companies by ambulatory, inpatient settings. April 07, 2017. https://ehrintelligence.com/news/ top-clinical-decision-support-system-cdss-companies-by-ambulatory-inpatient (дата обращения: 31.05.2019).

16. Olah P., et al. Exploring hierarchical medical data stored as multi-trees in a relational database. Proceedings of International Conference on Advancements of Medicine and Health Care through Technolo gy, October 12-15, 2016, Cluj-Napoca, Romania, IFMBE, vol. 59, S. Vlad, N. Roman (eds), Cham, Springer, 2016, pp. 219-222.

17. Лебедев С. В., Жукова Н. А. Слияние медицинских данных на основе онтологий. Онтология проектирования, 2017, т. 7, № 2(24), с. 145-159. doi:10. 18287/2223-9537-2017-7-2-145-159

18. Kaiser K., Marcos M. Leveraging workflow control patterns in the domain of clinical practice guidelines. BMC Medical Informatics and Decision Making, 2016, vol. 16, no. 20. https://doi.org/10.1186/s12911016-0253-z

19. Ong T. C., et al. Dynamic-ETL: a hybrid approach for health data extraction, transformation and loading. BMC Medical Informatics and Decision Making, 2017, vol. 17, no. 134. https://doi.org/10.1186/s12911017-0532-3

20. Sylvestre E., et al. Combining information from a clinical data warehouse and a pharmaceutical database to generate a framework to detect comorbidities in electronic health records. BMC Medical Informatics and Decision Making, 2018, vol. 18, no. 9. https:// doi.org/10.1186/s12911-018-0586-x

21. Новиков Ф. А., Афанасьева И. В. Кооперативное взаимодействие автоматных объектов. Инфорлаци онно-управляющие системь, 2016, № 6, с. 50-64. https://doi.org/10.15217/issn1684-8853.2016.6.50

22. Prieto-Langarica A., et al. A cellular automata model of infection control on medical implants. Appl Appl Math., Jun. 1, 2011, vol. 6, no. 1, pp. 1-10.

23. Misra S., Tiwari V., Obaidat M. S. LACAS: Learning automata-based congestion avoidance scheme for healthcare wireless sensor networks. IEEE Journal on Selected Areas in Communications, May 2009, vol. 27 , no. 4 , pp. 466-479.

24. Rahmaniheris M., Yu Jiang, Lui Sha. Model-driven design of clinical guidance systems. arXiv:1610.06895v1 [cs.CY], Oct. 21, 2016. https://arxiv.org/pdf/1610.06895. pdf (дата обращения: 31.05.2019).

25. Bowles J. K. F., Silvina A. Model Checking Cancer Automata. https://core.ac.uk/download/pdf/31299773. pdf (дата обращения: 31.05.2019).

26. Митькин С. Б. Автоматное программирование на языке ДРАКОН. Програмлная инженерия, 2019, т. 10, № 1 , с. $3-13$.

27. Gamma E., Helm R., Johnson R., Vlissides J. M. Design Patterns: Elements of Reusable Object-Oriented Software. 1st ed. Addison-Wesley Professional, 1994. $417 \mathrm{p}$.

28. Тепляков С. Погружение в паттерны проектирования. https://refactoring.guru/ru/design-patterns/ book (дата обращения: 31.05.2019). 
29. Vatian A., Dudorov S., Chikshova E., Lobantsev A., Parfenov V., Gusarova N., Shalyto A. Design patterns for personalization of healthcare process. 2 nd
International Conference on Software and Services Engineering, Prague, Czech Republic, March 15-17, 2019, pp. 83-88.

\section{UDC 004.895}

\section{doi:10.31799/1684-8853-2019-5-64-75}

\section{Automata approach for personalized support of clinical processes in healthcare}

\section{V. Aksenov ${ }^{\text {, }}$ Student, orcid.org/0000-0002-1835-2237}

N. V. Dobrenko a, Senior Lecturer, orcid.org/0000-0001-6206-8033

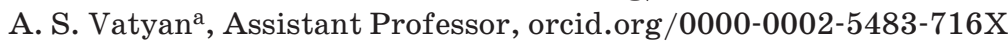

R. O. Kapustin ${ }^{a}$, Student, orcid.org/0000-0003-3027-2704

S. V. Osipova , Student, orcid.org/0000-0002-5761-4703

P. Y. Mavrin ${ }^{\text {a }, ~ S t u d e n t, ~ o r c i d . o r g / 0000-0001-8530-0077 ~}$

N. F. Gusarova ${ }^{a}$, PhD, Tech., Associate Professor, orcid.org/0000-0002-1361-6037

A. A. Shalyto ${ }^{a}$, Dr. Sc., Tech., Professor, orcid.org/0000-0002-2723-2077, shalyto@mail.ifmo.ru

aSaint-Petersburg National Research University of Information Technologies, Mechanics and Optics, 49,

Kronverkskii Pr., 197101, Saint-Petersburg, Russian Federation

Introduction: Within the framework of the National Healthcare Project, personalization of a physician's activity is very important, forming a demand for a Clinical Decision Support System. The available systems miss the functions of prompting a doctor during the clinical process or identifying possible contradictions between different types of medical treatment offered to the patient. Purpose: Development of a solution, free from the above-mentioned problems, for personalized support of the clinical process. Methods: Automata (state machine) approach presenting the clinical process as a set of automata states and possible transitions between them, and a set of design patterns, namely: Abstract Factory, Facade, Adapter and Visitor. Results: A solution for personalized support of clinical processes is proposed, based on the automata approach and design patterns. The automata approach allows you to divide the clinical process into separate stages and automatically control the possible transitions and conditions for their implementation, including checking for contraindications. The use of design patterns provides a sufficient degree of generalization, allowing you, without affecting the structure of the main application code, to promptly connect the system to the necessary sources of information, and to enter the data about contradictions of various origins, taking them into account when making decisions on the treatment of a particular patient. Practical relevance: The developed solution, as compared to the available systems, is more efficient at prompting the doctor during a clinical process, and at identifying possible contradictions between the various types of medical treatment offered to the patient.

Keywords - automata programming, state machine, clinical protocols, decision support, medical processes.

For citation: Aksenov I. V., Dobrenko N. V., Vatyan A. S., Kapustin R. O., Osipov S. V., Mavrin P. Y., Gusarova N. F., Shalyto A. A. Automata approach for personalized support of clinical processes in healthcare. Informatsionno-upravliaiushchie sistemy [Information and Control Systems], 2019, no. 5, pp. 64-75 (In Russian). doi:10.31799/1684-8853-2019-5-64-75

\section{References}

1. Brifing Ministra Veroniki Skvorczovoj. 13 dekabrya 2017 [Briefing by Minister Veronika Skvortsova. December 13 2017]. Available at: https://www.rosminzdrav.ru/news/2017/ 12/13/6603-brifing-ministra-veroniki-skvortsovoy-po-zavershenii-zasedaniya-prezidiuma-soveta-pri-prezidente-rossiyskoy-federatsii-po-strategicheskomu-razvitiyu-i-prioritetnym-proektam-pod-predsedatelstvom-dmitriya-medvedeva (accessed 31 May 2019).

2. OpenEHR Architecture Overview, openEHR 2007. Eds. S. Heard \& T. Beale. Available at: https://specifications. openehr.org/releases/1.0.2/architecture/overview.pdf (accessed 31 May 2019).

3. HL7 standard description. Available at: http://www.mcis. duke.edu/standarts/HL7/hl7.htm (accessed 31 May 2019).

4. Polikarpova N. I., Shalyto A. A. Avtomatnoe program mirovanie [Automatic programming]. Saint-Petersburg, Piter Publ., 2009. 176 p. (In Russian).

5. Vaganova E. V. Hospital information systems as the object of evaluation: factors and development tendencies. Vestnik Tomskogo gosudarstvennogo universiteta. E`konomika, 2017, no. 37, pp. 113-130 (In Russian).

6. ISO 13940-2016 Health informatics - system of concepts to support continuity of care (ISO 13940:2015). Available at: https://www.iso.org/standard/58102.html (accessed 31 May 2019).

7. Tsung-Hsien Yu, Pin-Kuei Fu, and Yu-Chi Tung. Using medication utilization information to develop an asthma severity classification model. BMC Medical Informatics and
Decision Making, Dec. 2017, vol. 17, p. 177. https://doi. org/10. 1186/s12911-017-0571-9

8. Nazarenko G. I., Osipov G. S. Osnovy teorii medicinskix texnologicheskix processov [Fundamentals of the theory of medical technological processes]. Part 1. Moscow, Fizmatlit Publ., 2005. 144 p. (In Russian).

9. Gusev A. Obzor rossijskix sistem podderzhki prinyatiya vrachebny'x reshenij [Overview of russian medical decision support systems]. Sent. 30, 2018. Available at: http://www. kmis.ru/blog/obzor-rossiiskikh-sistem-podderzhki-priniatiia-vrachebnykh-reshenii (accessed 31 May 2019).

10. Neumuth T. Surgical Process Modeling - Theory, Methods, and Applications. The Universität Leipzig, 2012. $279 \mathrm{p}$.

11. Hommersom A., Verwer S., Lucas P. J. F. Discovering probabilistic structures of healthcare processes. Process Sup port and Knowledge Representation in Health Care. Pro Health 2013, AIME 2013 Joint Workshop, KR4HC 2013/ ProHealth 2013, Murcia, Spain, June 1, 2013, Revised Selected Papers, pp. 53-67.

12. Ferrante S., Bonacina S., Pozzi G., Pinciroli F., Marceglia S. A design methodology for medical processes. Appl Clin Inform., 2016, vol. 7, pp. 191-210. http://dx.doi.org/10.4338/ ACI-2015-08-RA-0111

13. Zhaoyi Chen, Victoria Y. Bird, Rupam Ruchi, Mark S. Segal, Jiang Bian, Saeed R. Khan, Marie-Carmelle Elie, and Mattia Prosperi. Development of a personalized diagnostic model for kidney stone disease tailored to acute care by integrating large clinical, demographics and laboratory data: the diag- 
nostic acute care algorithm - kidney stones (DACA-KS). BMC Medical Informatics and Decision Making, 2018, vol. 18, no. 72. https://doi.org/10.1186/s12911-018-0652-4

14. Boussadi A., Zapletal E. A Fast Healthcare Interoperability Resources (FHIR) layer implemented over i2b2. BMC Medical Informatics and Decision Making, 2017, vol. 17, no. 120. https://doi.org/10.1186/s12911-017-0513-6

15. Monica K. Top Clinical Decision Support System (CDSS) companies by ambulatory, inpatient settings. April 07, 2017. Available at: https://ehrintelligence.com/news/top-clinical-decision-support-system-cdss-companies-by-ambulatory-inpatient (accessed 31 May 2019).

16. Olah P., et al. Exploring hierarchical medical data stored as multi-trees in a relational database. Proceedings of Interna tional Conference on Advancements of Medicine and Health Care through Technology, October 12-15, 2016, Cluj-Napoca, Romania, IFMBE, vol. 59, S. Vlad, N. Roman (eds), Cham, Springer, 2016, pp. 219-222.

17. Lebedev S. V., Zhukova N. A. Ontology-driven approach to medical data fusion. Ontology of Designing, 2017, vol. 7, no. 2, pp. 145-159 (In Russian). doi:10.18287/2223-95372017-7-2-145-159

18. Kaiser K., Marcos M. Leveraging workflow control patterns in the domain of clinical practice guidelines. $B M C$ Medical Informatics and Decision Making, 2016, vol. 16, no. 20. https://doi.org/10.1186/s12911-016-0253-z

19. Ong T. C., et al. Dynamic-ETL: a hybrid approach for health data extraction, transformation and loading. BMC Medical Informatics and Decision Making, 2017, vol. 17, no. 134. https://doi.org/10.1186/s12911-017-0532-3

20. Sylvestre E., et al. Combining information from a clinical data warehouse and a pharmaceutical database to generate a framework to detect comorbidities in electronic health records. BMC Medical Informatics and Decision Making, 2018, vol. 18, no. 9. https://doi.org/10.1186/s12911-018-0586-x
21. Novikov F. A., Afanasieva I. V. Cooperative interaction of automata objects. Informatsionno-upravliaiushchie sistemy [Information and Control Systems], 2016, no. 6, pp. 50-64 (In Russian). https://doi.org/10.15217/issn1684-8853.2016.6.50

22. Prieto-Langarica A., et al. A cellular automata model of infection control on medical implants. Appl Appl Math., Jun. 1, 2011 , vol. 6 , no. 1 , pp. $1-10$.

23. Misra S., Tiwari V., Obaidat M. S. LACAS: Learning automata-based congestion avoidance scheme for healthcare wireless sensor networks. IEEE Journal on Selected Areas in Communications, May 2009, vol. 27, no. 4, pp. 466-479.

24. Rahmaniheris M., Yu Jiang, Lui Sha. Model-driven design of clinical guidance systems. arXiv:1610.06895v1 [cs.CY] 21 Oct. 2016. Available at: https://arxiv.org/pdf/1610. 06895.pdf (accessed 31 May 2019).

25. Bowles J. K. F., Silvina A. Model Checking Cancer Automa ta. Available at: https://core.ac.uk/download/pdf/ 31299773.pdf (accessed 31 May 2019).

26. Mitkin S. Automata-based programming in DRAKON language. Programmnaya Ingeneria, 2019, vol. 10, no. 1 , pp. 3-13 (In Russian). doi:10.17587/prin.10.3-13

27. Gamma E., Helm R., Johnson R., Vlissides J. M. Design Patterns: Elements of Reusable Object-Oriented Software. 1st ed. Addison-Wesley Professional, 1994. $417 \mathrm{p}$.

28. Teplyakov S. Pogruzhenie v patterny proektirovaniya $[\mathrm{Im}-$ mersion in design patterns]. Available at: https://refactoring.guru/ru/design-patterns/book (accessed 31 May 2019).

29. Vatian A., Dudorov S., Chikshova E., Lobantsev A., Parfenov V., Gusarova N., Shalyto A. Design patterns for personalization of healthcare process. 2nd International Conference on Software and Services Engineering, Prague, Czech Republic, March 15-17, 2019, pp. 83-88.

\section{Научный журнал \\ «ИНФОРМАЦИОННО-УПРАВЛЯЮЩИЕ СИСТЕМЫ» выходит каждые два месяца.}

Стоимость годовой подписки (6 номеров) для подписчиков России -6000 рублей, для подписчиков стран СНГ - 6600 рублей, включая НДС $20 \%$, таможенные и почтовые расходы.

Подписку на печатную версию журнала можно оформить в любом отделении связи по каталогу: «Пресса России»: № 15385 - полугодовой индекс,

а также через посредство подписных агентств:

«Северо-Западное агентство „Прессинформ“”

Санкт-Петербург, тел.: (812) 335-97-51, 337-23-05,

эл. почта: press@crp.spb.ru, zajavka@crp.spb.ru,

сайт: http://www.pinform.spb.ru

«МК-Периодика» (РФ + 90 стран)

Москва, тел.: (495) 681-91-37, 681-87-47,

эл. почта: export@periodicals.ru, сайт: http://www.periodicals.ru

«Деловая пресса»

Москва, тел.: (495) 962-11-11, эл. почта: podpiska@delpress.ru,

сайт: http://delpress.ru/contacts.html

«Коммерсант-Курьер»

Казань, тел.: (843) 291-09-99, 291-09-47, эл. почта: kazan@komcur.ru,

сайт: http://www.komcur.ru/contacts/kazan/

«Урал-Пресс» (филиалы в 40 городах РФ)

Сайт: http://www.ural-press.ru

«Идея» (Украина)

Сайт: http://idea.com.ua

«BTL» (Узбекистан)

Сайт: http://btl.sk.uz/ru/cat17.html и др.

На электронную версию нашего журнала (все выпуски, годовая подписка, один выпуск, одна статья) вы можете подписаться на сайтах НЭБ: http://elibrary.ru; РУКОНТ: http://www.rucont.ru;

ИВИС: http://www.ivis.ru; Некс-Медиа: http://biblioclub.ru/index.php?page=news\&id=11196

Полнотекстовые версии журнала за 2002-2017 гг.

в свободном доступе на сайте журнала (http://www.i-us.ru),

НЭБ (http://www.elibrary.ru)

и Киберленинки (http://cyberleninka.ru/journal/n/informatsionno-upravlyayuschiesistemy). 

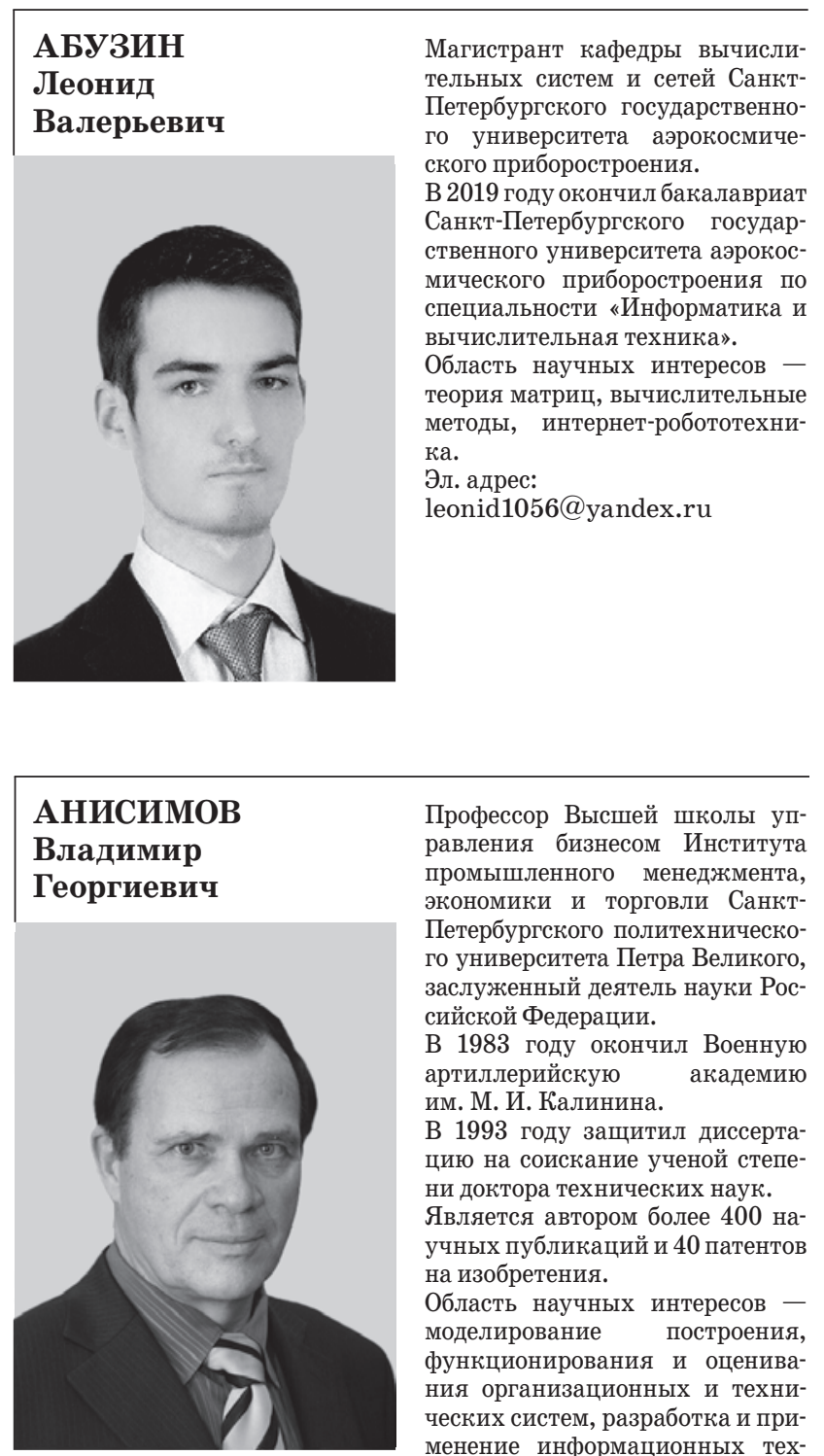

Профессор Высшей школы управления бизнесом Института промышленного менеджмента, экономики и торговли СанктПетербургского политехнического университета Петра Великого, заслуженный деятель науки Российской Федерации.

В 1983 году окончил Военную артиллерийскую академию им. М. И. Калинина.

В 1993 году защитил диссертацию на соискание ученой степени доктора технических наук. Является автором более 400 научных публикаций и 40 патентов на изобретения.

Область научных интересов моделирование построения, функционирования и оценивания организационных и технических систем, разработка и применение информационных технологий.

Эл. адрес: an-33@yandex.ru

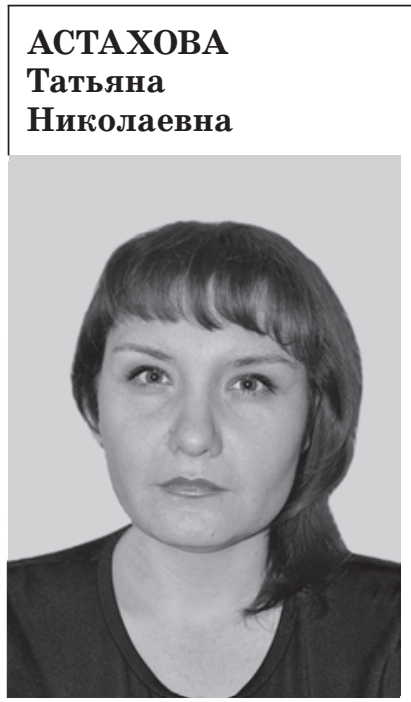

Доцент кафедры информационных систем и технологий Нижегородского государственного инженерно-экономического университета.

В 2006 году окончила магистратуру Донецкого национального университета по специальности «Математика».

В 2013 году защитила диссертацию на соискание ученой степени кандидата физико-математических наук.

Является автором более 60 научных публикаций.

Область научных интересов теория управления, информационные системы, системный анализ.

Эл. адрес: ctn_af@mail.ru

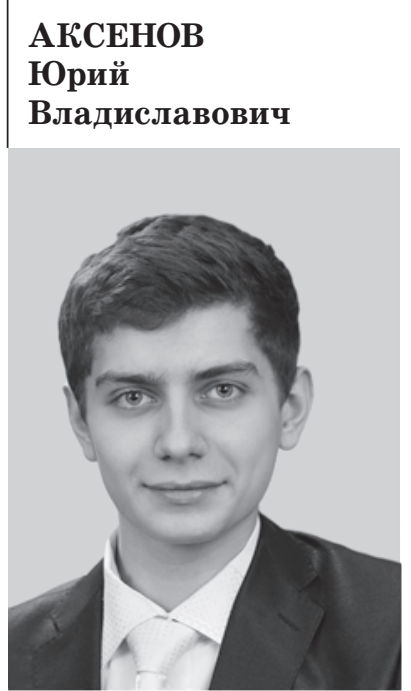

Студент факультета инфокоммуникационных технологий Университета ИТМО, Санкт-Петербург.

Область научных интересов проектирование информационных систем.

Эл. адрес:

iurii.aksenov@yandex.ru

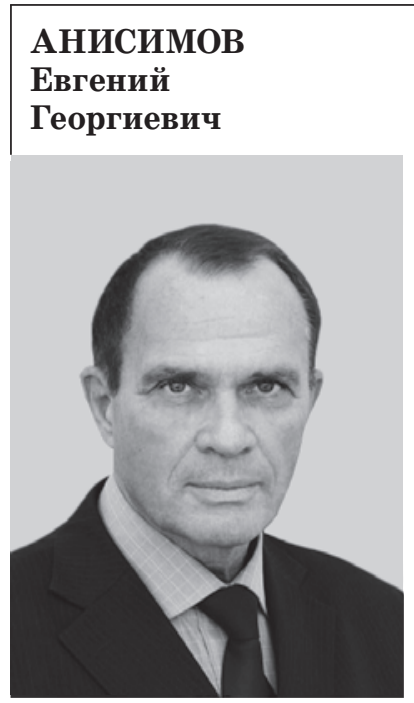

Профессор Российского университета дружбы народов, старший научный сотрудник Военного института Военной академии Генерального штаба ВС РФ, Москва, заслуженный деятель науки Российской Федерации.

В 1983 году окончил Военную артиллерийскую академию им. М. И. Калинина.

В 1998 году защитил диссертацию на соискание ученой степени доктора военных наук, в $2006-$ на соискание ученой степени доктора технических наук.

Является автором более 400 научных публикаций и 30 патентов на изобретения.

Область научных интересов системный анализ, прикладная математика, моделирование организационных и технических систем и др.

Эл. адрес: an-33@rambler.ru

\section{БАЛОНИН \\ Николай \\ Алексеевич}

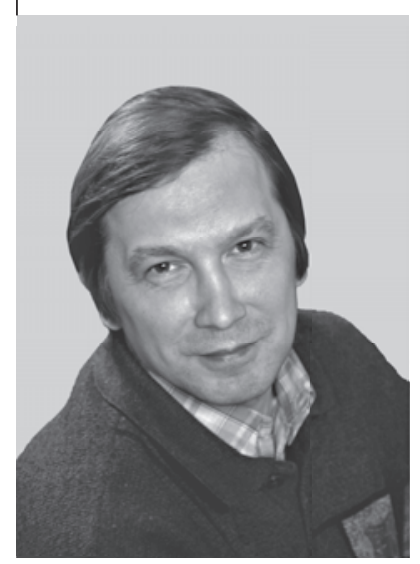

Профессор кафедры вычислительных систем и сетей СанктПетербургского государственного университета аэрокосмического приборостроения.

В 1982 году окончил Ленинградский электротехнический институт им. В. И. Ульянова (Ленина) по специальности «Автоматика и телемеханика».

В 2008 году защитил диссертацию на соискание ученой степени доктора технических наук. Является автором более 100 научных публикаций, в том числе трех монографий.

Область научных интересов теория динамических систем, теория идентификации, теория операторов, теория матриц, вычислительные методы, интернетробототехника, интернет-книги с исполняемыми алгоритмами, научные социальные сети.

Эл. адрес: korbendfs@mail.ru 


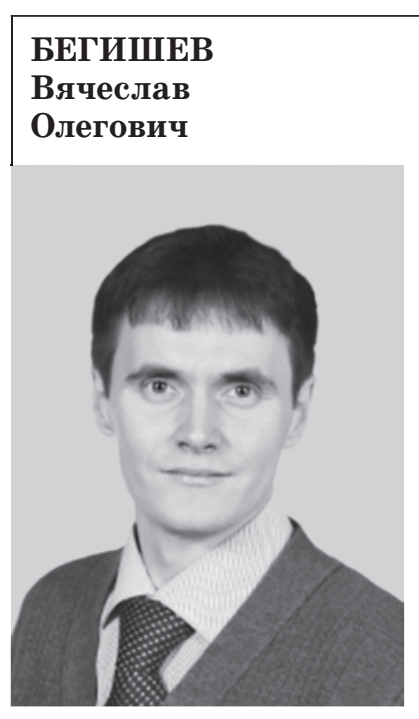

Ассистент кафедры прикладной информатики и теории вероятностей Российского университета дружбы народов, Москва.

В 2016 году окончил магистратуpy Российского университета дружбы народов по специальности «Прикладная математика». В 2019 году защитил диссертацию на соискание ученой степени кандидата физико-математических наук.

Является автором более 30 научных публикаций.

Область научных интересов беспроводные сети связи, анализ качества предоставления услуг. Эл. адрес: begishev-vo@rudn.ru

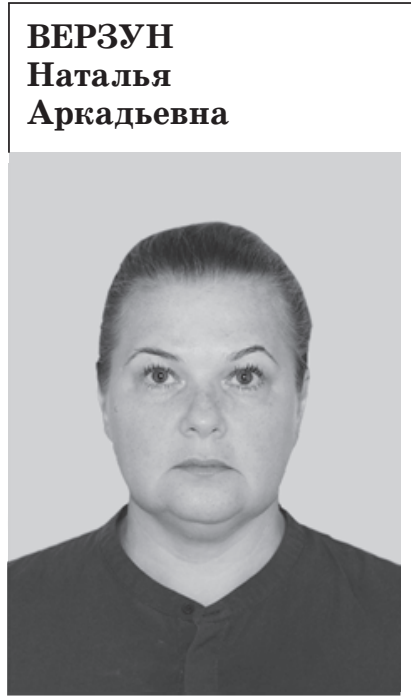

Доцент кафедры информационных систем Санкт-Петербургского государственного электротехнического университета «ЛЭТИ». В 1993 году окончила Ленинградский электротехнический институт связи им. проф. М. А. БончБруевича по специальности «Автоматическая электросвязь».

В 1999 году защитила диссертацию на соискание ученой степени кандидата технических наук. Является автором 60 научных публикаций.

Область научных интересов математическое моделирование информационных систем множественного доступа.

Эл. адрес: verzun,n@unecon.ru

\section{ГУСАРОВА \\ Наталия \\ Федоровна}

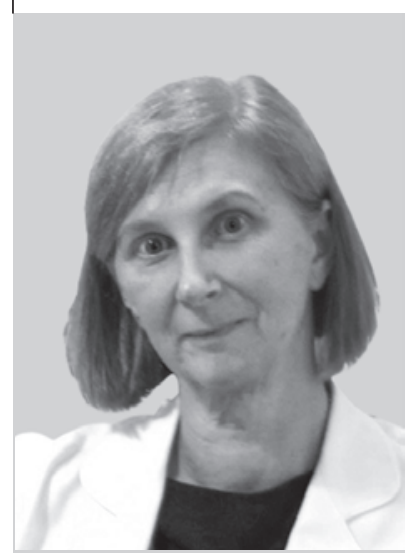

\section{ВАТЬЯН \\ Александра \\ Сергеевна}

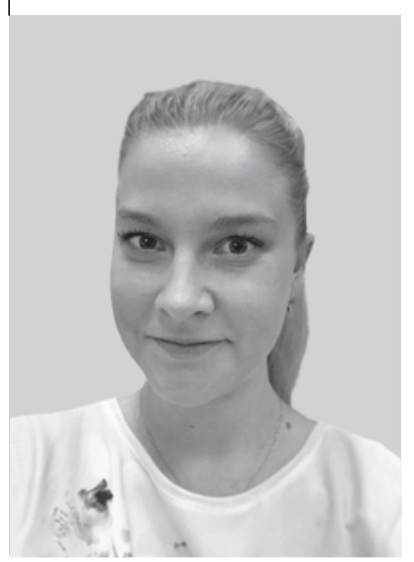

Ассистент факультета инфокоммуникационных технологий Университета ИТМО, СанктПетербург.

В 2014 году окончила Университет ИТМО по специальности «Прикладная информатика».

Является автором 21 научной публикации и шести РИД.

Область научных интересов машинное обучение, искусственный интеллект, автоматное программирование.

Эл. адрес:

alexvatyan@gmail.com

\section{ГАЙДАМАКА \\ Юлия}

Васильевна

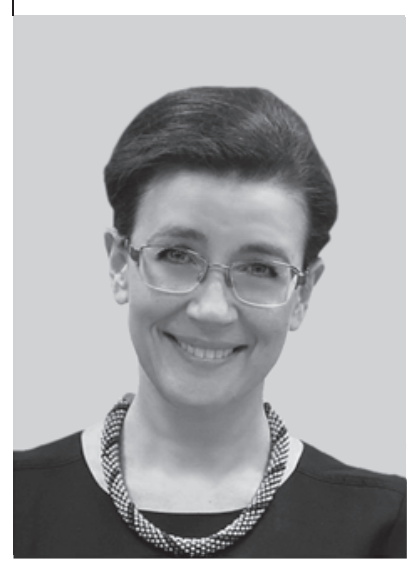

Профессор кафедры прикладной информатики и теории вероятностей Российского университета дружбы народов, старший научный сотрудник Института проблем информатики, Москва.

В 1995 году окончила магистратуру Российского университета дружбы народов по специальности «Прикладная математика и информатика».

В 2017 году защитила диссертацию на соискание ученой степени доктора физико-математических наук.

Является автором более 200 научных публикаций и 10 патентов на программы ЭВМ.

Область научных интересов математическая теория телетрафика мультисервисных сетей, беспроводные сети $5 \mathrm{G}$ и др.

Эл. адрес:

gaydamaka-yuv@rudn.ru

\section{джокович Драгомир} доцент факультета инфокомму никационных технологий Уни верситета ИТМО, Санкт-Петербург.

В 1974 году окончила Ленинградский институт точной механики и оптики по специальности «Оптико-электронные приборы». В 1984 году защитила диссертацию на соискание ученой степени кандидата технических наук. Является автором 95 научных публикаций и 47 свидетельств o регистрации программного продукта.

Область научных интересов машинное обучение, искусственный интеллект, автоматное программирование.

Эл. адрес: natfed@list.ru 


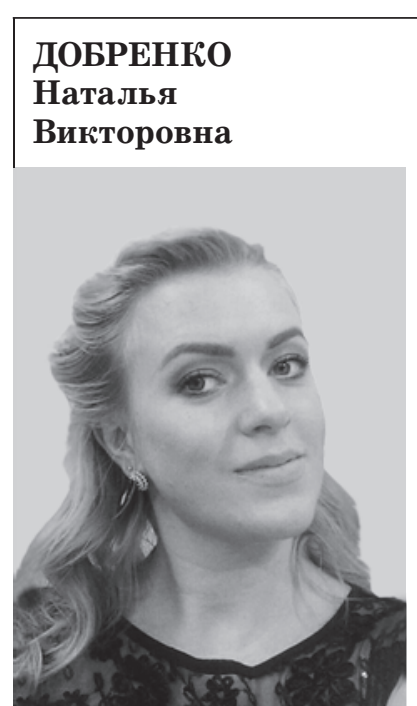

Старший преподаватель факультета инфокоммуникационных технологий Университета ИТМО, Санкт-Петербург.

В 2009 году окончила Университет ИТМО по специальности «Оптико-электронные приборы и системы видеонаблюдения».

В 2018 году защитила диссертацию на соискание ученой степени кандидата технических наук. Является автором 28 научных публикаций и 20 РИД.

Область научных интересов машинное обучение, искусственный интеллект, автоматное программирование.

Эл. адрес:

graziokisa@yandex.ru

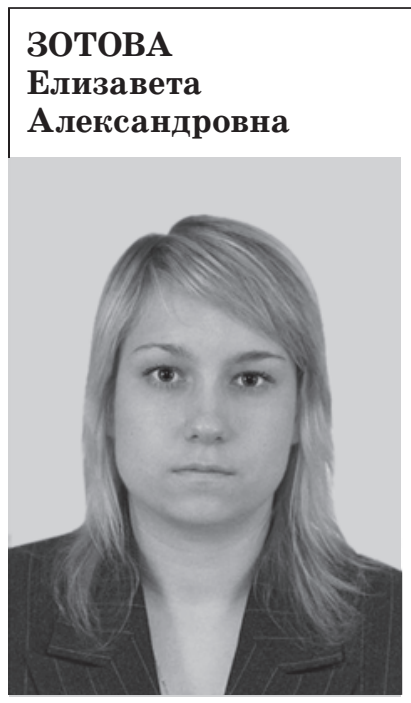

Ассистент Высшей школы управления бизнесом Института промышленного менеджмента, экономики и торговли СанктПетербургского политехнического университета Петра Великого.

В 2014 году окончила магистратуру Санкт-Петербургского государственного политехнического университета по специальности «Экономика».

Является автором 11 научных публикаций.

Область научных интересов бизнес-информатика, информационные системы в управлении. Эл. адрес: zea0284@gmail.com

\section{КАСАТКИН \\ Виктор \\ Викторович}

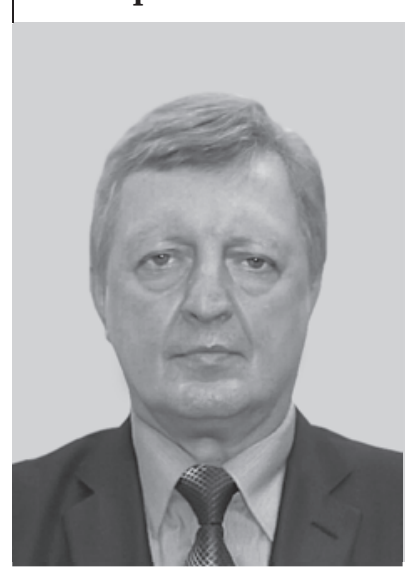

Доцент, исполнительный директор Санкт-Петербургского общества информатики, вычислительной техники, систем связи и управления, ученый секретарь Научного совета по информатизации Санкт-Петербурга, старший научный сотрудник Санкт-Петербургского института информатики и автоматизации РАН.

В 1977 окончил Ленинградский механический институт по специальности «Инженер-электромеханик».

В 1985 году защитил диссертацию на соискание ученой степени кандидата технических наук. Является автором 200 научных публикаций.

Область научных интересов информационные технологии в образовании, информационные системы и технологии.

Эл. адрес:

v.v.kasatkin@iias.spb.ru

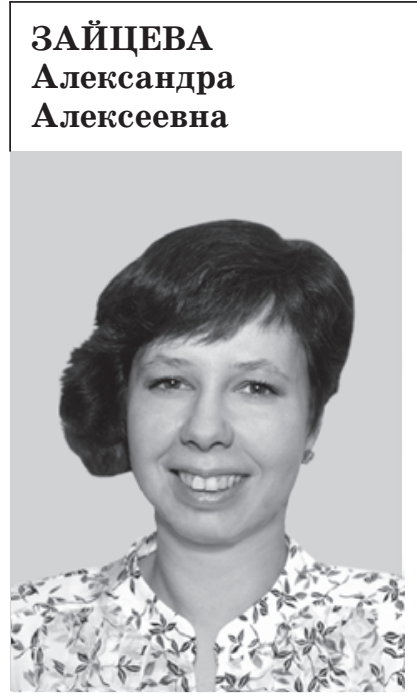

Старший научный сотрудник лаборатории автоматизации научных исследований СанктПетербургского института информатики и автоматизации PAH.

В 2001 году с отличием окончила магистратуру Санкт-Петербургского государственного технического университета по специальности «Системный анализ и управление».

В 2009 году защитила диссертацию на соискание ученой степени кандидата технических наук. Является автором 60 научных публикаций и восьми авторских свидетельств на РИД.

Область научных интересов инфокоммуникационные системы, методы и технологии обработки больших данных, обработка естественно-языковых текстов.

Эл. адрес: cher@iias.spb.su

\section{КАПУСТИН \\ Роман \\ Олегович}

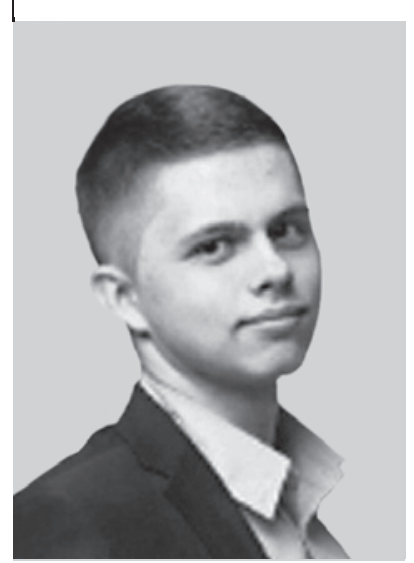

Студент факультета инфокоммуникационных технологий Университета ИТМО, Санкт-Петербург.

Область научных интересов проектирование информационных систем, системное программирование, архитектура мобильных приложений, компьютерные сети.

Эл. адрес:

remedictes@gmail.com

\section{КОЛБАНЕВ \\ Михаил}

Олегович

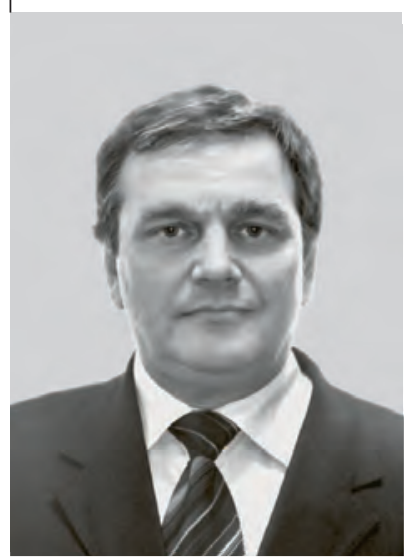

Профессор кафедры прикладных информационных техноло гий Санкт-Петербургского государственного университета сервиса и экономики. Мастер связи. В 1977 году окончил Ленинградский электротехнический институт связи им. проф. М. А. БончБруевича по специальности «Автоматическая электросвязь».

В 2004 году защитил диссертацию на соискание ученой степени доктора технических наук.

Является автором более 150 научных публикаций.

Область научных интересов моделирование информационных систем.

Эл. адрес: mokolbanev@mail.ru 


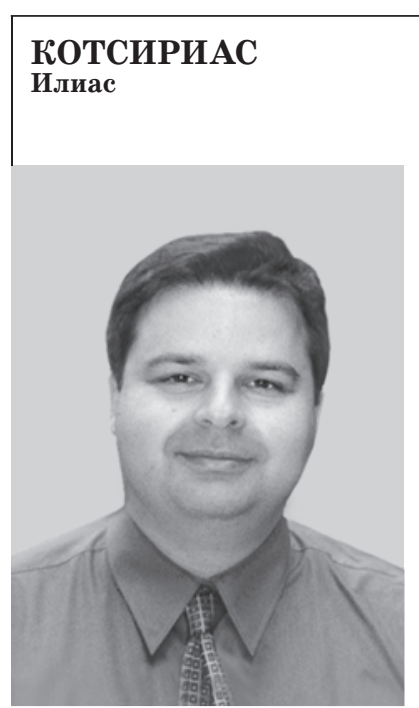

Профессор факультета физики и информатики университета Уилфрида Лорье, директор «CARGO lab» (Исследовательская группа компьютерной алгебры), Ватерлоо, Онтарио, Канада.

В 1990 году окончил бакалавриат факультета математики Афинского университета, Афины, Греция, в 1995 году - магистратуру факультета информатики Университета Париж 6, Париж, Франция.

В 1998 году защитил диссертацию на соискание ученой степени доктора наук (PhD).

Является автором более 80 научных публикаций.

Область научных интересов символьные вычисления, компьютерная алгебра, вычислительная алгебра, комбинаторная матричная теория, комбинаторная оптимизация и др.

Эл. адрес: ikotsire@wlu.ca

\section{МАВРИН \\ Павел \\ Юрьевич}

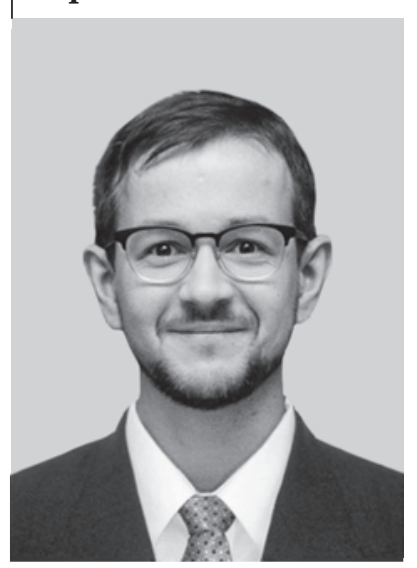

Тьютор факультета информационных технологий и программирования Университета ИТМО, Санкт-Петербург.

В 2008 году окончил Университет ИТМО по специальности «Прикладная математика и информатика».

Является автором трех научных публикаций.

Область научных интересов алгоритмы и структуры данных, олимпиадное программирование.

Эл. адрес:

pavel.mavrin@gmail.com

\section{НИКИФОРОВ \\ Виктор \\ Викентьевич}

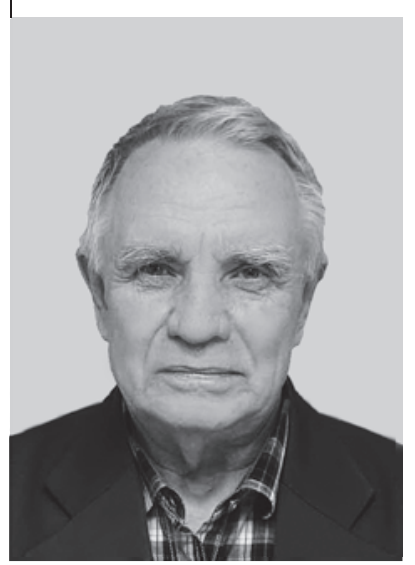

\section{КУЛЕШОВ \\ Сергей \\ Викторович}

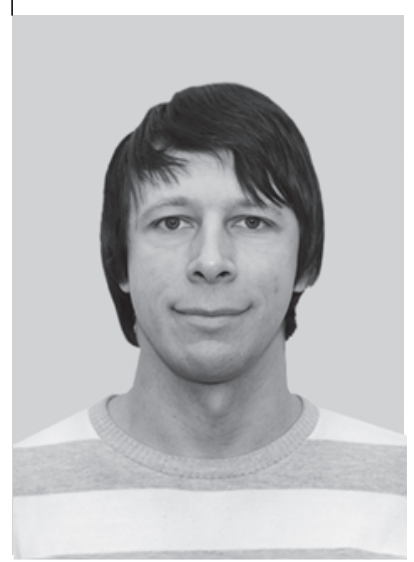

Главный научный сотрудник, руководитель лаборатории автоматизации научных исследований Санкт-Петербургского института информатики и автоматизации РАН.

В 2003 году с отличием окончил Курганский государственный университет по специальности «Программное обеспечение вычислительной техники и автоматизированных систем».

В 2011 году защитил диссертацию на соискание ученой степени доктора технических наук.

Является автором 90 научных публикаций и десяти авторских свидетельств на РИД.

Область научных интересов инфокоммуникационные системы и компьютерная лингвистика, ассоциативно-онтологическая обработка естественно-языковых текстов.

Эл. адрес: kuleshov@iias.spb.su

\section{МОЛЧАНОВ \\ Дмитрий}

Александрович

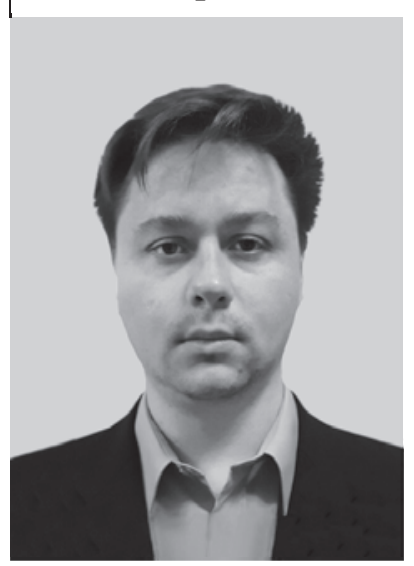

Доцент, старший научный сотрудник кафедры прикладной информатики и теории вероятностей Российского университета дружбы народов, Москва.

В 2000 году окончил магистратуру Санкт-Петербургского университета телекоммуникаций им. проф. М. А. Бонч-Бруевича по специальности «Сети связи и системы коммутации».

В 2002 году защитил диссертацию на соискание ученой степени кандидата технических наук. Является автором более 150 научных публикаций.

Область научных интересов математическая теория телетрафика мультисервисных сетей, беспроводные сети 5G New Radio, анализ качества предоставления услуг в сетях 5G, интернет вещей.

Эл. адрес:

molchanov-da@rudn.ru

\section{ОСИПОВ \\ Василий Юрьевич} и технологй Санкт-Петербургского института информатики и автоматизации РАН.

В 1965 году окончил Ленинградский политехнический институт по специальности «Радиотехника».

В 1991 году защитил диссертацию на соискание ученой степени доктора технических наук.

Является автором 120 научных публикаций.

Область научных интересов системы реального времени, встроенные системы, операционные системы.

Эл. адрес: nik@iias.spb.su

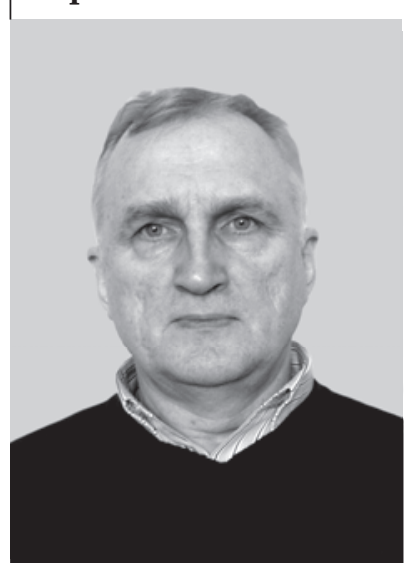

Профессор, ведущий научный сотрудник Санкт-Петербургского института информатики и автоматизации РАН.

В 1981 году окончил Высшее военно-морское училище радиоэлектроники им. А. С. Попова по специальности «Радиотехнические средства».

В 2000 году защитил диссертацию на соискание ученой степени доктора технических наук. Является автором более 100 научных публикаций.

Область научных интересов интеллектуальные системы, моделирование, информационная безопасность.

Эл. адрес: osipov_vasiliy@mail.ru 


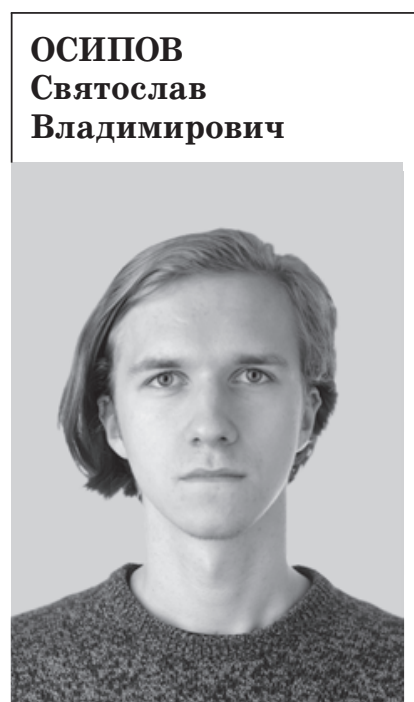

Студент факультета инфокоммуникационных технологий Университета ИТМО, Санкт-Петербург.

Область научных интересов проектирование информационных систем, системное программирование, архитектура ЭВМ. Эл. адрес: antiproton2013@yandex.ru

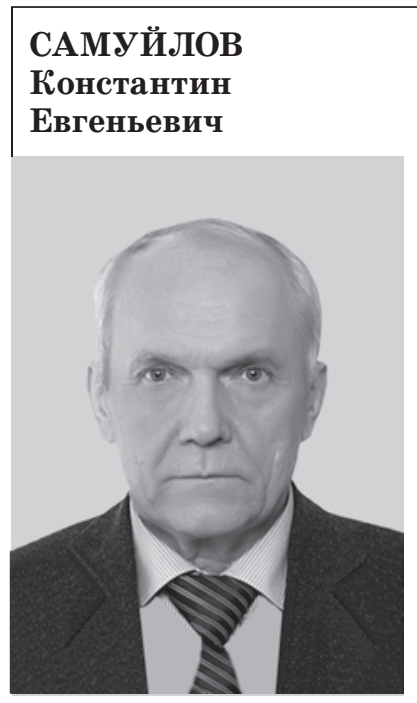

Профессор, заведующий кафедрой прикладной информатики и теории вероятностей Российского университета дружбы народов, ведущий научный сотрудник Института проблем информатики РАН, Москва.

В 1978 году окончил Университет дружбы народов им. П. Лумумбы по специальности «Математик».

В 2005 году защитил диссертацию на соискание ученой степени доктора технических наук. Является автором 300 научных публикаций и четырех патентов на программы ЭВМ.

Область научных интересов математическая теория телетрафика, беспроводные сети IoT, анализ качества предоставления услуг в беспроводных сетях IоT и $5 \mathrm{G}$ и др.

Эл. адрес: samuylov-ke@rudn.ru

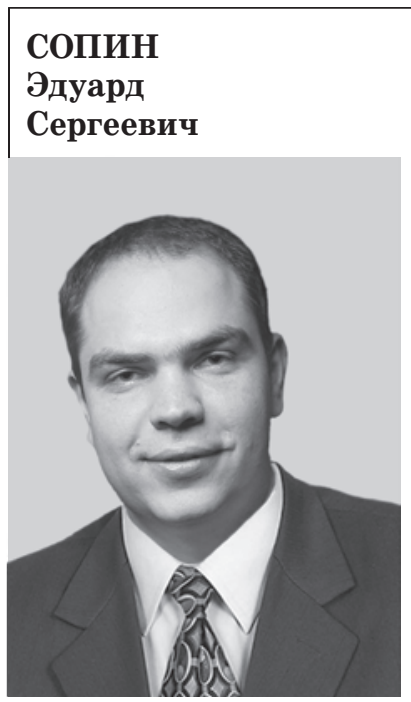

Доцент кафедры прикладной информатики и теории вероятностей Российского университета дружбы народов, старший научный сотрудник Института проблем информатики Федерального исследовательского центра «Информатика и управление» РАН, Москва.

В 2010 году окончил магистратуpy Российского университета дружбы народов по специальности «Прикладная математика и информатика».

В 2013 году защитил диссертацию на соискание ученой степени кандидата физико-математических наук.

Является автором более 70 научных публикаций.

Область научных интересов математическая теория телетрафика, беспроводные сети $5 \mathrm{G}$ и др. Эл. адрес: sopin-es@rudn.ru
САМУЙЛОВ
Андрей

Константинович

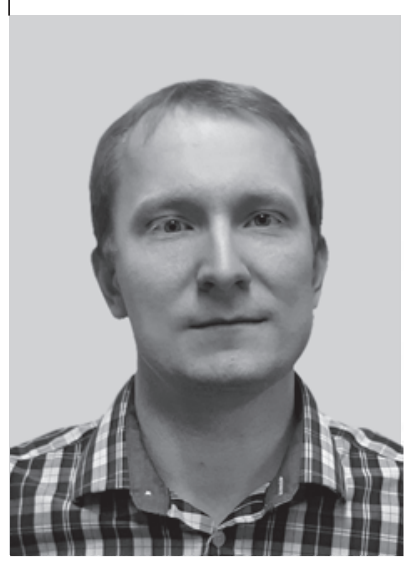

Доцент кафедры прикладной информатики и теории вероятностей Российского университета дружбы народов, Москва.

В 2012 году окончил магистратуру Российского университета дружбы народов по специальности «Прикладная математика». В 2015 году защитил диссертацию на соискание ученой степени кандидата физико-математических наук.

Является автором более 70 научных публикаций.

Область научных интересов беспроводные сети связи, анализ качества предоставления услуг.

Эл. адрес:

samuylov_ak@rudn.ru

\section{САУ РЕНКО \\ Татьяна}

Николаевна

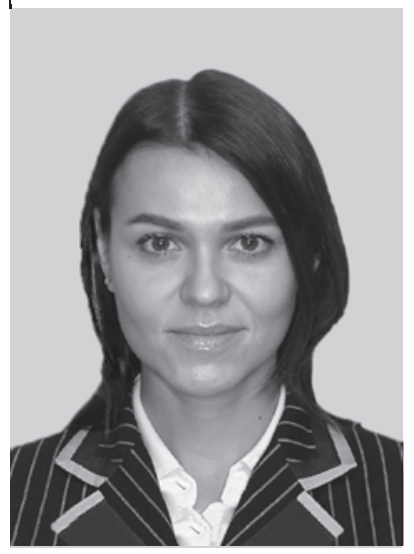

Заведующая кафедрой таможенного дела Российского университета дружбы народов, Москва. В 2003 году окончила Пятигорский государственный лингвистический университет по специальности «Управление внешнеэкономической деятельностью». В 2014 году защитила диссертацию на соискание ученой степени доктора экономических наук. Является автором более 60 научных публикаций.

Область научных интересов внешнеэкономическая деятельность, мировая экономика, таможенное дело.

Эл. адрес: tanya@saurenko.ru

\section{ТАТАРНИКОВА \\ Татьяна Михайловна}

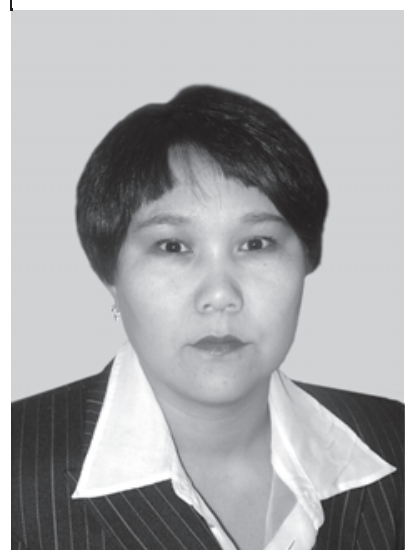

Профессор кафедры безопасности информационных систем Санкт-Петербургского государственного университета аэрокосмического приборостроения.

В 1993 году окончила ВосточноСибирский технологический институт по специальности «Электронно-вычислительные машины, комплексы, системы и сети». В 2007 году защитила диссертацию на соискание ученой степени доктора технических наук. Является автором более 100 научных публикаций.

Область научных интересов инфокоммуникации, взаимодействие неоднородных сетей.

Эл. адрес: tm-tatarn@yandex.ru 


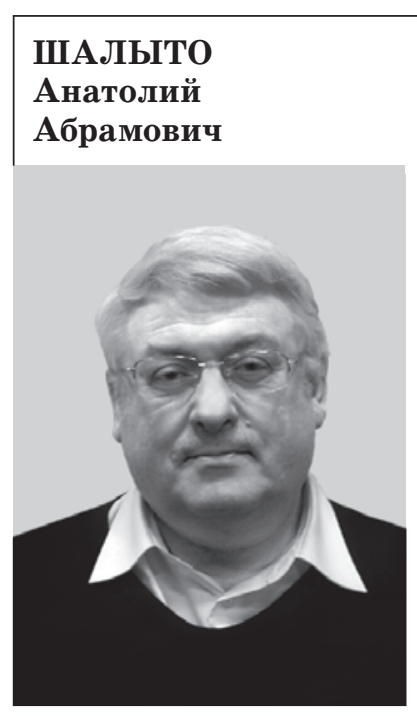

Профессор факультета информационных технологий и программирования Университета ИТМО, ученый секретарь НПО «Авроpa».

В 1971 году окончил Ленинградский электротехнический институт им. В. И. Ульянова (Ленина) по специальности «Автоматика и телемеханика».

В 1999 году защитил диссертацию на соискание ученой степени доктора технических наук. Является автором более 250 научных публикаций, трех монографий и 70 изобретений.

Область научных интересов системы логического управления, автоматное программирование.

Эл. адрес: shalyto@mail.ifmo.ru

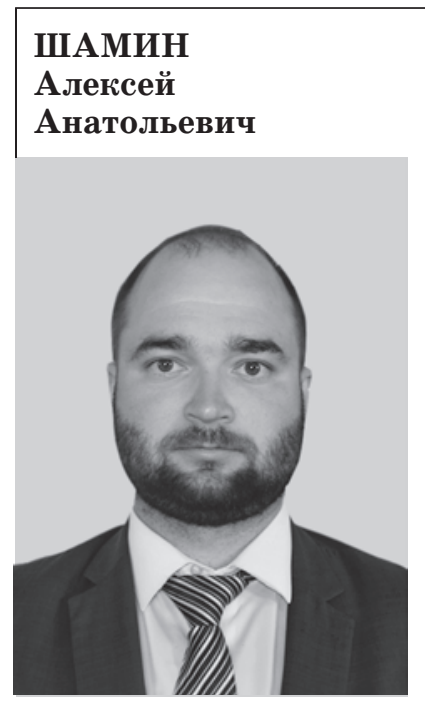

Доцент, директор Института информационных технологий и систем связи, Княгинино.

В 2012 году окончил магистратуру Нижегородского государственного университета им. Н. И. Лобачевского по специальности «Информационные технологии». В 2015 году защитил диссертацию на соискание ученой степени кандидата экономических наук.

Является автором 34 научных публикаций.

Область научных интересов сенсорные сети, факторы сельскохозяйственного производства, архитектура цифровой экономики.

Эл. адрес: ngiei-spo@mail.ru

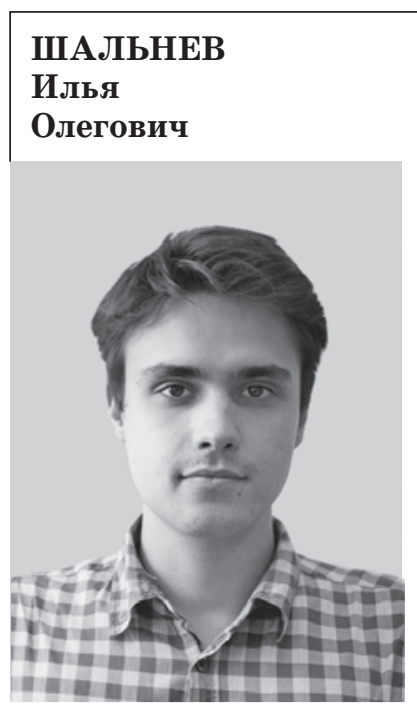

Аспирант, программист лаборатории автоматизации научных исследований Санкт-Петербургского института информатики и автоматизации $\mathrm{PAH}$.

В 2018 году с отличием окончил Санкт-Петербургский государственный университет аэрокосмического приборостроения по специальности «Программная инженерия».

Является автором трех научных публикаций.

Область научных интересов распределенные виртуальные машины, активные данные, реконфигурируемые системы. Эл. адрес:

elias.shalnev@gmail.com

\section{ПАМЯТКА АМЯ АВТОРОВ}

Поступающие в редакиию статьи проходят обязательное рецензирование.

При наличии положительной рецензии статья рассматривается редакционной коллегией. Принятая в печать статья направляется автору для согласования редакторских правок. После согласования автор представляет в редакцию окончательный вариант текста статьи.

Процедуры согласования текста статьи могут осуществляться как непосредственно в редакции, так и по е-mail (ius.spb@gmail.com).

При отклонении статьи редакция представляет автору мотивированное заключение и рецензию, при необходимости доработать статью - рецензию.

Редакиия журнала наполинает, что ответственность за достоверность и точность реклалных материалов несут реклалодатели. 


\section{Уважаемые авторы!}

При подготовке рукописей статей необходимо руководствоваться следующими рекомендациями.

Статьи должны содержать изложение новых научных результатов. Название статьи должно быть кратким, но информативным. В названии недопустимо использование сокращений, кроме самых общепринятых (РАН, РФ, САПР и т. п.).

Объем статьи (текст, таблицы, иллюстрации и библиография) не должен превышать эквивалента в 20 страниц, напечатанных на бумаге формата A4 на одной стороне через 1,5 интервала Word шрифтом Times New Roman paзмером 13, поля не менее двух сантиметров.

Обязательными элементами оформления статьи являются: индекс Удк, заглавие, инициалы и фамилия автора (авторов), ученая степень, звание (при отсутствии - должность), полное название организации, аннотация и ключевые слова на русском и английском языках, ORCID и электронный адрес одного из авторов. При написании аннотации не используйте аббревиатур и не делайте ссылок на источники в списке литературы. Предоставляйте подрисуночные подписи и названия таблиц на русском и английском языках.

Статьи авторов, не имеющих ученой степени, рекомендуется публиковать в соавторстве с научным руководителем, наличие подписи научного руководителя на рукописи обязательно; в случае самостоятельной публикации обязательно предоставляйте заверенную по месту работы рекомендацию научного руководителя с указанием его фамилии, имени, отчества, места работы, должности, ученого звания, ученой степени.

Формулы набирайте в Word, не используя формульный редактор (Mathtype или Equation), при необходимости можно использовать формульный редактор; для набора одной формулы не используйте два редактора; при наборе формул в формульном редакторе знаки препинания, ограничивающие формулу, набирайте вместе с формулой; для установки размера шрифта никогда не пользуйтесь вкладкой Other..., используйте заводские установки редактора, не подгоняйте размер символов в формулах под размер шрифта в тексте статьи, не растягивайте и не сжимайте мышью формулы, вставленные в текст; в формулах не отделяйте пробелами знаки: + = -

Для набора формул в Word никогда не используйте Конструктор (на верхней панели: «Работа с формулами» «Конструктор»), так как этот ресурс предназначен только для внутреннего использования в Word и не поддерживается программами, предназначенными для изготовления оригинал-макета журнала.

При наборе символов в тексте помните, что символы, обозначаемые латинскими буквами, набираются светлым курсивом, русскими и греческими - светлым прямым, векторы и матрицы - прямым полужирным шрифтом.

Иллюстрации предоставляются отдельными исходными файлами, поддающимися редактированию:

- рисунки, графики, диаграммы, блок-схемы предоставляйте в виде отдельных исходных файлов, поддающихся редактированию, используя векторные программы: Visio (*.vsd, *.vsdx); Coreldraw (*.cdr); Excel (*.xls); Word (*.docx); Adobe Illustrator (*.ai); AutoCad (*.dxf); Matlab (*.ps, *.pdf или экспорт в формат *.ai);

- если редактор, в котором Вы изготавливаете рисунок, не позволяет сохранить в векторном формате, используйте функцию экспорта (только по отношению к исходному рисунку), например, в формат *.ai, *.esp, *.wmf, *.emf, $*$.svg;

- фото и растровые - в формате *.tif, *.png с максимальным разрешением (не менеe 300 pixels/inch).

Наличие подрисуночных подписей и названий таблиц на русском и английском языках обязательно (желательно не повторяющих дословно комментарии к рисункам в тексте статьи).

В редакцию предоставляются:

- сведения об авторе (фамилия, имя, отчество, место работы, должность, ученое звание, учебное заведение и год его окончания, ученая степень и год защиты диссертации, область научных интересов, количество научных публикаций, домашний и служебный адреса и телефоны, e-mail), фото авторов: анфас, в темной одежде на белом фоне, должны быть видны плечи и грудь, высокая степень четкости изображения без теней и отблесков на лице, фото можно представить в электронном виде в формате *.tif, *.png с максимальным разрешением - не менее 300 pixels/inch при минимальном размере фото $40 \times 55$ мм;

- экспертное заключение.

Список литературы составляется по порядку ссылок в тексте и оформляется следующим образом:

- для книг и сборников - фамилия и инициалы авторов, полное название книги (сборника), город, издательство, год, общее количество страниц;

- для журнальных статей - фамилия и инициалы авторов, полное название статьи, название журнала, год издания, номер журнала, номера страниц;

- ссылки на иностранную литературу следует давать на языке оригинала без сокращений;

- при использовании web-материалов указывайте адрес сайта и дату обращения.

Список литературы оформляйте двумя отдельными блоками по образцам lit.dot на сайте журнала (http://i-us. $\mathrm{ru}$ /paperrules): Литература и References.

Более подробно правила подготовки текста с образцами изложены на нашем сайте в разделе «Правила для авторов» .

Контакты

Куда: 190000 , Санкт-Петербург,

Б. Морская ул., д. 67, ГУАП, РИЦ

Кому: Редакция журнала «Информационно-управляющие системы» Тел.: (812) 494-70-02

Эл. почта: ius.spb@gmail.com

Сайт: www.i-us.ru 